Nevada

Environmental

Restoration

Project

\title{
Corrective Action Decision Document for Corrective Action Unit 140: Waste Dumps, Burn Pits, and Storage Area, Nevada Test Site, Nevada
}

Controlled Copy No.:

Revision No.: 0

October 2003

Approved for public release; further dissemination unlimited.

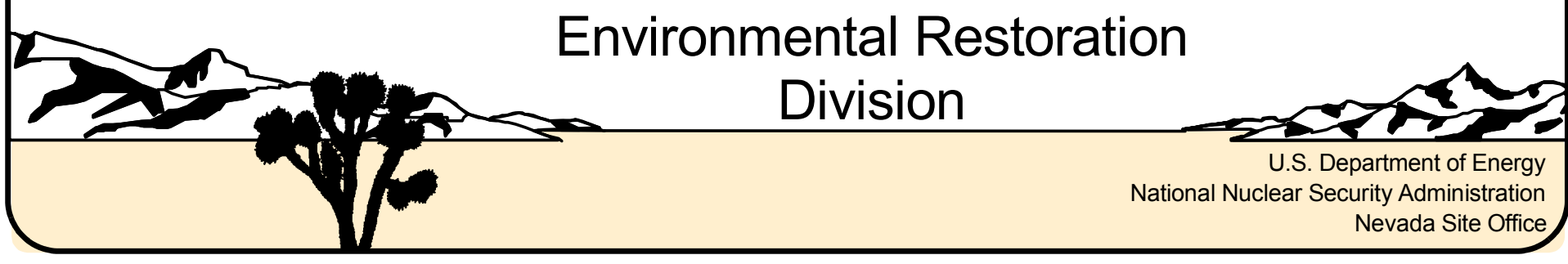


Available for public sale, in paper, from:

U.S. Department of Commerce

National Technical Information Service

5285 Port Royal Road

Springfield, VA 22161

Phone: 800.553 .6847

Fax: 703.605.6900

Email: orders@ntis.gov

Online ordering: http://www.ntis.gov/ordering.htm

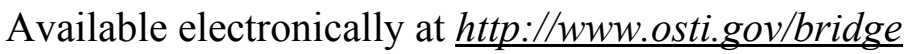

Available for a processing fee to U.S. Department of Energy and its contractors, in paper, from:

\section{U.S. Department of Energy}

Office of Scientific and Technical Information

P.O. Box 62

Oak Ridge, TN 37831-0062

Phone: 865.576 .8401

Fax: 865.576.5728

Email: reports@adonis.osti.gov

Reference herein to any specific commercial product, process, or service by trade name, trademark, manufacturer, or otherwise, does not necessarily constitute or imply its endorsement, recommendation, or favoring by the United States Government or any agency thereof or its contractors or subcontractors. 


\title{
CORRECTIVE ACTION DECISION DOCUMENT FOR CORRECTIVE ACTION UNIT 140: WASTE DUMPS, BURN PITS, AND STORAGE AREA, NEVADA TEST SITE, NEVADA
}

\author{
U.S. Department of Energy \\ National Nuclear Security Administration \\ Nevada Site Office \\ Las Vegas, Nevada
}

Controlled Copy No.:

Revision No.: 0

October 2003

Approved for public release; further dissemination unlimited. 


\section{CORRECTIVE ACTION DECISION DOCUMENT FOR}

CORRECTIVE ACTION UNIT 140:

WASTE DUMPS, BURN PITS, AND STORAGE AREA, NEVADA TEST SITE, NEVADA

Approved by: Signature Approved

Date: $10 / 9 / 03$

Janet Appenzeller-Wing, Project Manager

Industrial Sites Project

Approved by: Signature Approved

Date: $10-09-03$

Runore C. Wycoff, Division Director

Environmental Restoration Division 


\section{Table of Contents}

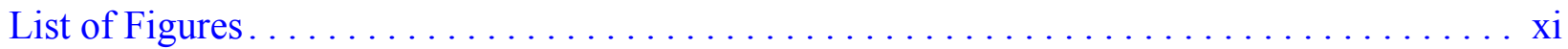

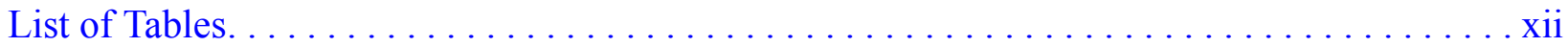

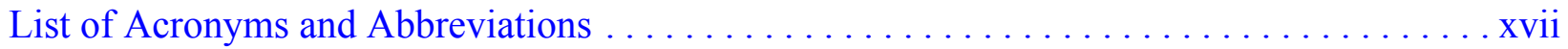

Executive Summary . . . . . . . . . . . . . . . . . . . . . . . . ES-1

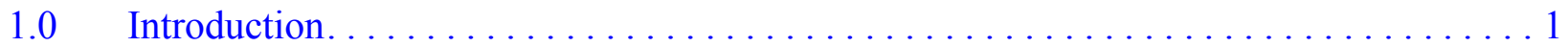

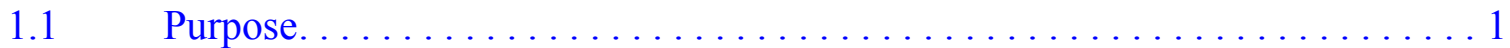

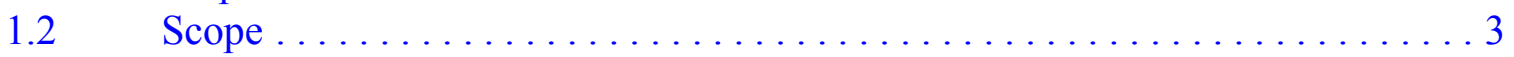

1.3 Corrective Action Decision Document Contents. .................4

$2.0 \quad$ Corrective Action Investigation Summary $\ldots \ldots \ldots \ldots \ldots \ldots \ldots \ldots \ldots \ldots \ldots \ldots \ldots$

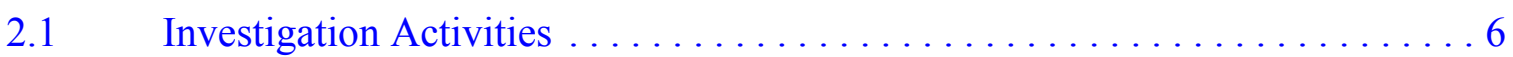

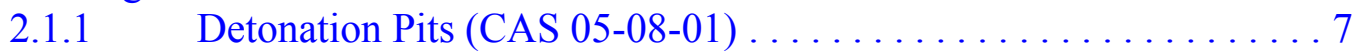

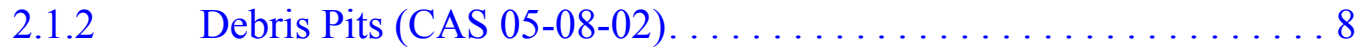

2.1.3 Hazardous Waste Accumulation Site (Buried) (CAS 05-17-01) . . . 8

2.1.4 Waste Disposal Site (CAS 05-19-01) . . . . . . . . . . . . 9

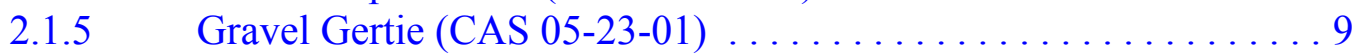

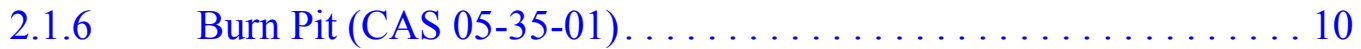

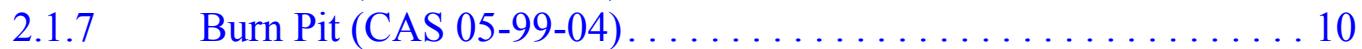

2.1.8 Radioactive Waste Dump (CAS 22-99-04) . . . . . . . . . . . . . 10

2.1.9 Hazardous Waste Storage Area (CAS 23-17-01) . . . . . . . . . . 11

$2.2 \quad$ Results . . . . . . . . . . . . . . . . . . . . . . . . 12

2.2.1 Summary of Characterization Data . . . . . . . . . . . . . 12

2.2.1.1 Detonation Pits (CAS 05-08-01) .......... 13

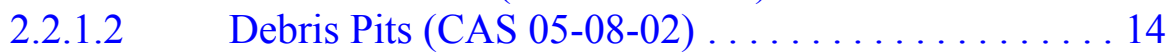

2.2.1.3 Hazardous Waste Accumulation Site

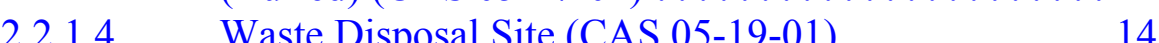

2.2.1.5 Gravel Gertie (CAS 05-23-01) .......... 14

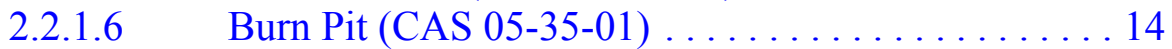

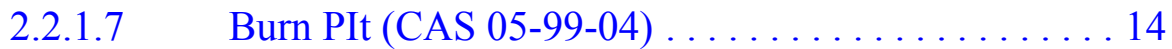

2.2.1.8 Radioactive Waste Dump (CAS 22-99-04) . . . . . 15

2.2.1.9 Hazardous Waste Storage Area (CAS 23-17-01) . . 15

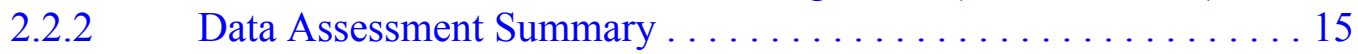

$2.3 \quad$ Need for Corrective Action . . . . . . . . . . . . . . . . . . . . . 16

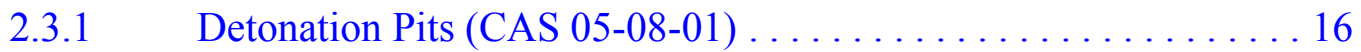

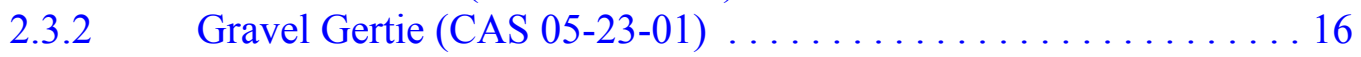

2.3.3 Hazardous Waste Storage Area (CAS 23-17-01) . . . . . . . . . 17 


\section{Table of Contents (Continued)}

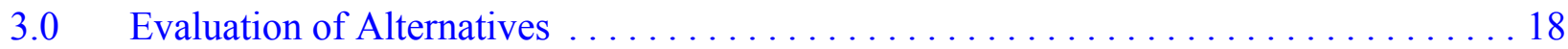

$3.1 \quad$ Corrective Action Objectives. . . . . . . . . . . . . . . . . . . . 18

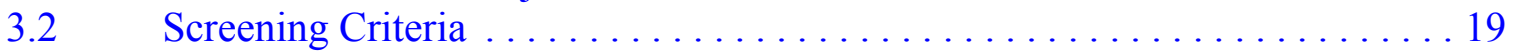

3.2.1 Corrective Action Standards . . . . . . . . . . . . . . . . 19

3.2.2 Remedy Selection Decision Factors . . . . . . . . . . . . 21

3.3 Development of Corrective Action Alternatives ................ 22

3.3.1 Alternative 1 - No Further Action ................... 23

3.3.2 Alternative 2 - Clean Closure ..................... 23

3.3.2.1 Detonation Pits (CAS 05-08-01) . . . . . . . . 24

3.3.2.2 Gravel Gertie (CAS 05-23-01) ............ 24

3.3.2.3 Hazardous Waste Storage Area (CAS 23-17-01) . . . 24

3.3.3 Alternative 3 - Close in Place with Administrative Controls . . . . 25

3.3.3.1 Detonation Pits (CAS 05-08-01) ........... 25

3.3.3.2 Gravel Gertie (CAS 05-23-01) . ...........26

3.3.3.3 Hazardous Waste Storage Area (CAS 23-17-01) . . 28

$3.4 \quad$ Evaluation and Comparison of Alternatives . . . . . . . . . . . . . . . 29

$4.0 \quad$ Recommended Alternatives . . . . . . . . . . . . . . . . . . . . . . . . . . . . . . . . . . 34

$5.0 \quad$ References........................................... 35

\section{Appendix A - Corrective Action Investigation Report for Corrective Action Unit 140}

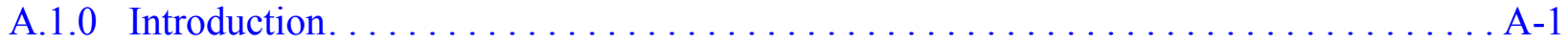

A.1.1 Objectives ..................................

A.1.2 Report Content............................ A-

A.2.0 Investigation Overview. ............................ A-3

A.2.1 Preliminary Conceptual Model $\ldots \ldots \ldots \ldots \ldots \ldots \ldots \ldots \ldots \ldots \ldots$ A -4

A.2.2 Sample Locations.......................... A

A.2.2.1 Housekeeping Removal of Debris .................. A-4

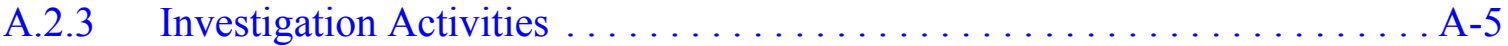

A.2.3.1 Excavations ............................ A-5

A.2.3.2 Backhoe and Hand Sampling Methodology ............ A-6

A.2.3.3 Rotosonic Sampling at CAS $23-17-01 \ldots \ldots \ldots \ldots \ldots \ldots \ldots$. . 6

A.2.4 Field-Screening Methodology $\ldots \ldots \ldots \ldots \ldots \ldots \ldots \ldots \ldots \ldots \ldots \ldots \ldots \ldots \ldots \ldots$

A.2.5 Geology and Hydrology. . . . . . . . . . . . . . . . . . . . A -7

A.2.6 Laboratory Analytical Information $\ldots \ldots \ldots \ldots \ldots \ldots \ldots \ldots \ldots \ldots \ldots \ldots \ldots$

A.2.7 Comparison to Preliminary Action Levels .................. A-10

A.2.7.1 Residual Surficial Plutonium Contamination at

Frenchman Lake Area . . . . . . . . . . . . . . . . . . . . . . A-13 


\section{Table of Contents (Continued)}

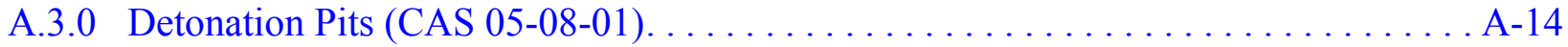

A.3.1 Corrective Action Investigation. . . . . . . . . . . . . . . . . . A-14

A.3.1.1 Deviations ............................... A-14

A.3.2 Investigation Results . ............................ A-16

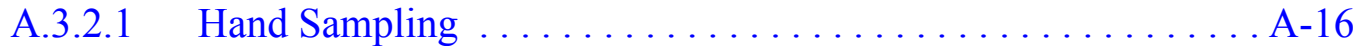

A.3.2.2 Inspection of Gravel Pile . . . . . . . . . . . . . . . . A-17

A.3.2.3 Field-Screening Results . . . . . . . . . . . . . . . . A-17

A.3.2.4 Sample Analyses ......................... A-17

A.3.2.5 Analytes Detected Above Minimum Reporting Limits........ A-17

A.3.2.5.1 Total Volatile Organic Compound

Analytical Results for Soil Samples .......... A-18

A.3.2.5.2 Total Semivolatile Organic Compound

Analytical Results for Soil Samples .......... A-18

A.3.2.5.3 Total Petroleum Hydrocarbon Analytical

Results for Soil Samples ................ A-19

A.3.2.5.4 Total RCRA Metals Analytical Results

for Soil Samples .................... A-19

A.3.2.5.5 Polychlorinated Biphenyl Analytical Results for Soil Samples . . . . . . . . . . . . . A-20

A.3.2.5.6 Explosives .................... A-20

A.3.2.5.7 Gamma Spectrometry Results for Soil Samples . . A-20

A.3.2.5.8 Isotopic Uranium Analytical Results for Soil Samples .................. A-22

A.3.2.5.9 Isotopic Plutonium Analytical Results for Soil Samples .................. A-22

A.3.2.5.10 Strontium-90 Analytical Results for

Soil Samples ...................... A-22

A.3.2.6 Contaminants of Concern ...................... A-22

A.3.3 Nature and Extent of Contaminants of Concern . . . . . . . . . . . A-22

A.3.4 Revised Conceptual Site Model. ...................... A-23

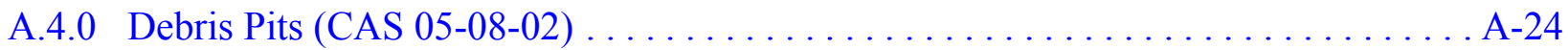

A.4.1 Corrective Action Investigation. . . . . . . . . . . . . . . . A-24

A.4.1.1 Deviations .............................. A-24

A.4.2 Investigation Results . ........................... A-24

A.4.2.1 Hand Sampling ........................... A-24

A.4.2.2 Field-Screening Results ..................... A-27

A.4.2.3 Sample Analyses ....................... A-27

A.4.2.4 Analytes Detected Above Minimum Reporting Limits. . . . . . . A-27 


\section{Table of Contents (Continued)}

A.4.2.4.1 Total Volatile Organic Compound

Analytical Results for Soil Samples .......... A-27

A.4.2.4.2 Total Semivolatile Organic Compound

Analytical Results for Soil Samples ......... A-27

A.4.2.4.3 Total Petroleum Hydrocarbon Analytical

Results for Soil Samples . . . . . . . . . . . . . A-28

A.4.2.4.4 Total RCRA Metals Analytical Results for Soil Samples . . . . . . . . . . . . . . . A-28

A.4.2.4.5 Polychlorinated Biphenyl Analytical

Results for Soil Samples . . . . . . . . . . . . A-28

A.4.2.5 Contaminants of Concern . . . . . . . . . . . . . . . . A-30

A.4.3 Nature and Extent of Contaminants of Concern . . . . . . . . . . . . A-30

A.4.4 Revised Conceptual Site Model....................... A-30

A.5.0 Hazardous Waste Accumulation Site (Buried) (CAS 05-17-01) . ........... A-31

A.5.1 Corrective Action Investigation. . . . . . . . . . . . . . . A-31

A.5.1.1 Deviations ............................... A-31

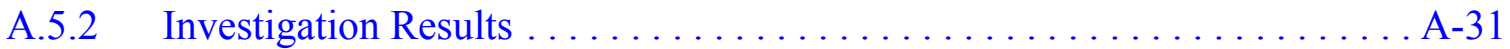

A.5.2.1 Hand Sampling ......................... A-33

A.5.2.2 Inspection of Soil Mound $\ldots \ldots \ldots \ldots \ldots \ldots \ldots \ldots \ldots$ A-33

A.5.2.3 Field-Screening Results ...................... A-34

A.5.2.4 Sample Analyses .......................... A-34

A.5.2.5 Analytes Detected Above Minimum Reporting Limits. ...... . A-34

A.5.2.5.1 Total Volatile Organic Compound

Analytical Results for Soil Samples .......... A-34

A.5.2.5.2 Total Semivolatile Organic Compound

Analytical Results for Soil Samples .......... A-34

A.5.2.5.3 Total Petroleum Hydrocarbon Analytical

Results for Soil Samples ................ A-34

A.5.2.5.4 Total RCRA Metals Analytical Results for Soil Samples ...................... A-35

A.5.2.5.5 Polychlorinated Biphenyl Results

for Soil Samples ..................... A-35

A.5.2.5.6 Explosives ...................... A-35

A.5.2.5.7 Pesticides ...................... A-35

A.5.2.6 Contaminants of Concern ...................... A-35

A.5.3 Nature and Extent of Contaminants of Concern . . . . . . . . . . . A-36

A.5.4 Revised Conceptual Site Model. ..................... A-36

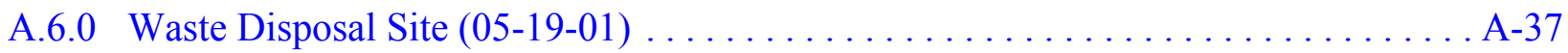

A.6.1 Corrective Action Investigation. . . . . . . . . . . . . . . A 37 


\section{Table of Contents (Continued)}

A.6.1.1 Deviations ............................... A-37

A.6.2 Investigation Results . ........................... A-37

A.6.2.1 Hand Sampling ........................... A-37

A.6.2.2 Backhoe Sampling ...................... A-40

A.6.2.3 Inspection of the Middle Disposal Area . . . . . . . . . . . A-40

A.6.2.4 Field-Screening Results . . . . . . . . . . . . . . . . . . A-40

A.6.2.5 Sample Analyses ........................ A-40

A.6.2.6 Analytes Detected Above Minimum Reporting Limits....... A-41

A.6.2.6.1 Total Volatile Organic Compound Analytical Results for Soil Samples ................ A-41

A.6.2.6.2 Total Semivolatile Organic Compound Analytical Results for Soil Samples .......... A-41

A.6.2.6.3 Total Petroleum Hydrocarbon Analytical Results for Soil Samples ................ A-41

A.6.2.6.4 Total RCRA Metals Analytical Results for Soil Samples . . . . . . . . . . . . . . . A A-42

A.6.2.6.5 Polychlorinated Biphenyl Results for Soil Samples . . . . . . . . . . . . . . . A-42

A.6.2.6.6 Gamma Spectrometry Results for Soil Samples . . A-42

A.6.2.6.7 Isotopic Uranium Results for Soil Samples .... . . A-42

A.6.2.6.8 Isotopic Plutonium Results for Soil Samples . . . A A-42

A.6.2.6.9 Strontium-90 Results for Soil Samples . . . . . . . A-42

A.6.2.7 Contaminants of Concern . . . . . . . . . . . . . . . . A-42

A.6.3 Nature and Extent of COCs . . . . . . . . . . . . . . . . . A-45

A.6.4 Revised Conceptual Site Model. ......................... A-45

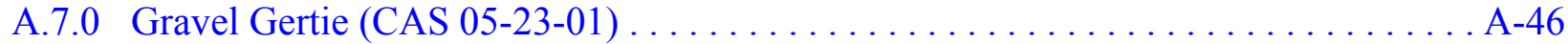

A.7.1 Corrective Action Investigation. . . . . . . . . . . . . . . A-46

A.7.1.1 Deviations ............................. A-46

A.7.2 Investigation Results . .......................... A-46

A.7.2.1 Hand Sampling ......................... A-48

A.7.2.2 Field-Screening Results . . . . . . . . . . . . . . . A-48

A.7.2.3 Sample Analyses ....................... A-48

A.7.2.4 Analytes Detected Above Minimum Reporting Limits........ A-49

A.7.2.4.1 Antimony Analytical Results for Soil Samples ... A-49

A.7.2.4.2 Polychlorinated Biphenyl Results for Soil Samples . . . . . . . . . . . . . . . A A-49

A.7.2.5 Explosives ............................ A-49

A.7.2.5.1 Gamma Spectrometry Results for Soil Samples . . A-49

A.7.2.5.2 Isotopic Uranium Results for Soil Samples .... . . A-49

A.7.2.5.3 Isotopic Plutonium Results for Soil Samples .... A-49 


\section{Table of Contents (Continued)}
A.7.2.5.4 Strontium-90 Results for Soil Samples ... . . . . A-51
A.7.2.6 Contaminants of Concern . . . . . . . . . . . . . . A-51
A.7.3 Nature and Extent of Contaminants of Concern . . . . . . . . . . . . . . . . A-51
A.7.4 Revised Conceptual Site Model. . . . . . . . . . . . . . . . A-51

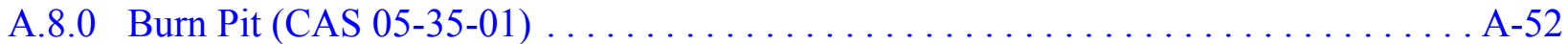

A.8.1 Corrective Action Investigation. . . . . . . . . . . . . . . A-52

A.8.1.1 Deviations ......................... A-52

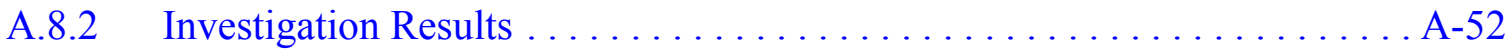

A.8.2.1 Soil Sampling. . . . . . . . . . . . . . . . A-52

A.8.2.2 Field-Screening Results . . . . . . . . . . . . . . . . . A-54

A.8.2.3 Sample Analyses . . . . . . . . . . . . . . . . . . A-54

A.8.2.4 Analytes Detected Above Minimum Reporting Limits. . . . . . . A A-54

A.8.2.4.1 Total Volatile Organic Compound

Analytical Results for Soil Samples ... . . . . . A-55

A.8.2.4.2 Total Semivolatile Organic Compound

Analytical Results for Soil Samples ... . . . . . A-55

A.8.2.4.3 Total Petroleum Hydrocarbon Analytical

Results for Soil Samples ... . . . . . . . . A A-55

A.8.2.4.4 Total RCRA Metals Analytical Results for Soil Samples .................. A-55

A.8.2.4.5 Polychlorinated Biphenyl Results

for Soil Samples . . . . . . . . . . . . . . . A-55

A.8.2.5 Contaminants of Concern . . . . . . . . . . . . . . . . A-56

A.8.3 Nature and Extent of Contaminants of Concern . . . . . . . . . . . . A-56

A.8.4 Revised Conceptual Site Model. . . . . . . . . . . . . . . . . . A -56

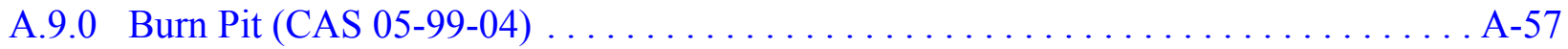

A.9.1 Corrective Action Investigation. . . . . . . . . . . . . . A-57

A.9.1.1 Deviations ........................ A-57

A.9.2 Investigation Results . . . . . . . . . . . . . . . . A-57

A.9.2.1 Soil Sampling. . . . . . . . . . . . . . . . . . A-57

A.9.2.2 Field-Screening Results . . . . . . . . . . . . . . . A 57

A.9.2.3 Sample Analyses . . . . . . . . . . . . . . . . . . . A-59

A.9.2.4 Analytes Detected Above Minimum Reporting Limits . . . . . . . A-59

A.9.2.4.1 Total Volatile Organic Compound

Analytical Results for Soil Samples . . . . . . . A A-59

A.9.2.4.2 Total Semivolatile Organic Compound

Analytical Results for Soil Samples . . . . . . . . . A-59

A 9.2.4.3 Total Petroleum Hydrocarbons Analytical

Results for Soil Samples . . . . . . . . . . . . A-60 


\section{Table of Contents (Continued)}
A.9.2.4.4 Total RCRA Metals Analytical Results
for Soil Samples ................... A-60
A.9.2.4.5 Polychlorinated Biphenyl Results
for Soil Samples ................... A-60

A.9.2.5 Contaminants of Concern .................... A-60

A.9.3 Nature and Extent of Contaminants of Concern . . . . . . . . . . . . . A-60

A.9.4 Revised Conceptual Site Model. . . . . . . . . . . . . . . . . . . A-61

A.10.0 Radioactive Waste Dump (CAS 22-99-04) . . . . . . . . . . . . . . . . . A A-62

A.10.1 Corrective Action Investigation. . . . . . . . . . . . . . . . . A-62

A.10.1.1 Deviations ............................. A-62

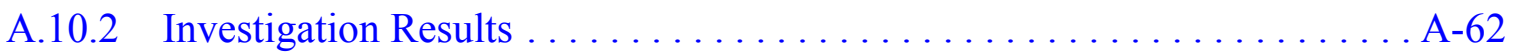

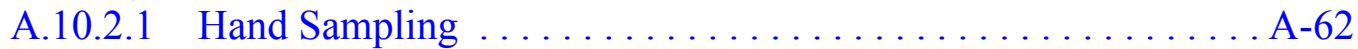

A.10.2.2 Field-Screening Results . . . . . . . . . . . . . . . . A-64

A.10.2.3 Sample Analyses ........................ A-64

A.10.2.4 Analytes Detected Above Minimum Reporting Limits........ A-64

A.10.2.4.1 Polychlorinated Biphenyl Results for Soil Samples . . . . . . . . . . . . . . . A-64

A.10.2.4.2 Gamma Spectrometry Results for Soil Samples . . A-64

A.10.2.4.3 Gross Beta ..................... A-65

A.10.2.4.4 Strontium-90 Results for Soil Samples ........ A-65

A.10.2.5 Contaminants of Concern ..................... A-65

A.10.3 Nature and Extent of Contaminants of Concern . . . . . . . . . . . . . A-66

A.10.4 Revised Conceptual Site Model. ...................... A-66

A.11.0 Hazardous Waste Storage Area, (CAS 23-17-01) . . . . . . . . . . . . . . . A-67

A.11.1 Corrective Action Investigation. . . . . . . . . . . . . . . . . A-67

A.11.1.1 Deviations ............................... A-67

A.11.2 Investigation Results . ......................... A-67

A.11.2.1 Geophysical Survey ........................ A-73

A.11.2.2 Inspection of the Landfill Dimensions. . . . . . . . . . . A-73

A.11.2.3 Backhoe Sampling ........................ A-75

A.11.2.4 Rotosonic Sampling......................... A-75

A.11.2.5 Geotechnical Samples ....................... A-76

A.11.2.6 Topographic Survey of Landfill Surface . . . . . . . . . . . A-76

A.11.2.7 Field-Screening Results . . . . . . . . . . . . . . . . A-76

A.11.2.8 Sample Analyses . . . . . . . . . . . . . . . . . . A-76

A.11.2.9 Analytes Detected Above Minimum Reporting Limits. ...... . A-78

A.11.2.9.1 Total Volatile Organic Compound

Analytical Results for Soil Samples ......... A-78 


\section{Table of Contents (Continued)}

\section{A.11.2.9.2 Total Semivolatile Organic Compound}

Analytical Results for Soil Samples

A-78

A.11.2.9.3 Total Petroleum Hydrocarbon

Analytical Results for Soil Samples ... . . . . . A-79

A.11.2.9.4 Total RCRA Metals Results for Soil Samples .... A-79

A.11.2.9.5 Ethylene Glycol . . . . . . . . . . . . . . . A-79

A.11.2.9.6 Polychlorinated Biphenyl Results

for Soil Samples . . . . . . . . . . . . . A-79

A.11.2.9.7 Pesticides . . . . . . . . . . . . . . A-79

A.11.2.9.8 Herbicides ................... A-80

A.11.2.9.9 Tritium ................... A-80

A.11.2.10 Contaminants of Concern . . . . . . . . . . . . . . . A-80

A.11.3 Nature and Extent of COCs . . . . . . . . . . . . . . . . . . . A-80

A.11.4 Revised Conceptual Site Model. . . . . . . . . . . . . . . . . . . . A-83

A.12.0 Waste Management. . . . . . . . . . . . . . . . . . . . . . . A-85

A.12.1 Waste Minimization. ......................... A-85

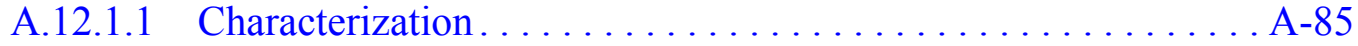

A.12.1.2 Waste Streams . . . . . . . . . . . . . . . . . . . . A-85

A.12.2 Investigation-Derived Waste Generated . . . . . . . . . . . . . . . A-86

A.12.2.1 Waste Management Samples. . . . . . . . . . . . . . . . . . A-86

A.13.0 Quality Assurance. . . . . . . . . . . . . . . . . . . . . . . . . .

A.13.1 Data Validation .............................. A 87

A.13.1.1 Tier I Evaluation . . . . . . . . . . . . . . . . A-87

A.13.1.2 Tier II Evaluation. . . . . . . . . . . . . . . . . . . . A-88

A.13.1.3 Tier III Review. . . . . . . . . . . . . . . . . . . . . . . . . . A-90

A.13.2 Quality Control Samples . . . . . . . . . . . . . . . . . . . . . A-90

A.13.2.1 Field Quality Control Samples ..... . . . . . . . . . . . A A-91

A.13.2.2 Laboratory Quality Control Samples. . . . . . . . . . . . . . . . . A-91

A.13.3 Field Nonconformances. . . . . . . . . . . . . . . . . . . . . . . A-91

A.13.4 Laboratory Nonconformances . . . . . . . . . . . . . . . . A-92

A.14.0 Summary . . . . . . . . . . . . . . . . . . . . . . . . . .

A.15.0 References. . . . . . . . . . . . . . . . . . . . . . . . . . . . . . . . A-94

\section{Appendix B - Data Assessment for CAU 140}

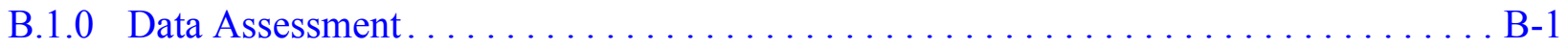

B.1.1 Statement of Usability . . . . . . . . . . . . . . . . . 


\section{Table of Contents (Continued)}

B.1.1.1 Precision...............................

B.1.1.1.1 Precision for Chemical Analyses ............ B-2

B.1.1.1.2 Precision for Radiological Analysis . . . . . . . B-7

B.1.1.1.3 Precision Summary $\ldots \ldots \ldots \ldots \ldots \ldots . . . \ldots$ B-10

B.1.1.2 Accuracy .......................... B-10

B.1.1.2.1 Accuracy for Chemical Analysis ............ B-10

B.1.1.2.2 Accuracy for Radiological Analysis . . . . . . . . B-12

B.1.1.2.3 Accuracy Summary ................. B-16

B.1.1.3 Completeness............................. B-17

B.1.1.4 Rejected Data............................. B-21

B.1.1.5 Representativeness........................ B-24

B.1.1.6 Comparability ...........................

B.1.2 Reconciliation of Conceptual Site Models to the Data .............. B-26

B.1.2.1 Conceptual Site Models....................... B-26

B.1.2.1.1 Surface Materials Conceptual Site Model ..... . B-26

B.1.2.1.2 Buried Debris Conceptual Site Model ........ B-27

B.1.2.1.3 Internal Structure Conceptual Site Model ...... B-27

B.1.2.2 Investigation Design and Contaminant Identification ......... B-27

B.1.2.3 Contaminant Nature and Extent. . . . . . . . . . . . . . B-28

B.1.3 Conclusions ............................... 28

B.2.0 References........................................ B-29

\section{Appendix C - Cost Estimates for CAU 140}

\section{Appendix D - Sample Location Coordinates for CAU 140}

D.1.0 Sample Location Coordinates. . . . . . . . . . . . . . . . . . . . D-1

D.1.1 Detonation Pits (CAS 05-08-01) .......................

D.1.2 Debris PIts (CAS 05-08-02) ..........................

D.1.3 Hazardous Waste Accumulation Site (Buried) (CAS 05-17-01) . . . . . . . . D-2

D.1.4 Waste Disposal Site (CAS 05-19-01) . . . . . . . . . . . . . . . D-2

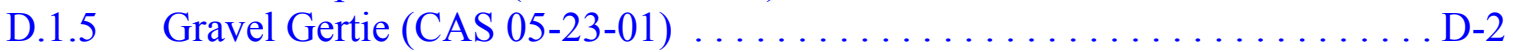

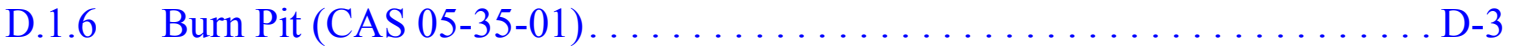

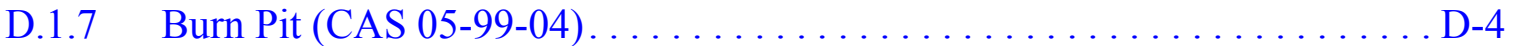

D.1.8 Radioactive Waste Dump (CAS 22-99-04) . . . . . . . . . . . . D-5

D.1.9 Hazardous Waste Storage Area (CAS 23-17-01) .............. D-5

\section{Appendix E - Evaluation of Risk}

E.1.0 Evaluation of Risk . . . . . . . . . . . . . . . . . . . . . . . . . . . . . E-1 


\section{Table of Contents (Continued)}

Appendix F - Project Organization for CAU 140

F.1.0 Project Organization $\ldots \ldots \ldots \ldots \ldots \ldots \ldots \ldots \ldots \ldots \ldots \ldots \ldots \ldots \ldots \ldots \ldots \ldots \ldots$

\section{Appendix G - NDEP Comments}




\section{List of Figures}

Number

Title

Page

1-1 Nevada Test Site and CAU 140 Site Map........................ 2

A.3-1 Sample Locations and Points of Interest at CAS 05-08-01, Detonation Pits .... A-15

A.4-1 Sampling Locations and Points of Interest at CAS 05-08-02, Debris Pits ...... A-26

A.5-1 Sampling Locations and Points of Interest at CAS 05-17-01, Hazardous Waste Accumulation Site (Buried) . . . . . . . . . . . . . A-32

A.6-1 Sampling Locations and Points of Interest at CAS 05-19-01, Waste Disposal Site................................ A-38

A.7-1 Sampling Locations and Points of Interest at CAS 05-23-01, Gravel Gertie . . . . A-47

A.8-1 Sampling Locations and Points of Interest at CAS 05-35-01, Burn Pit ....... A-53

A.9-1 Sampling Locations and Points of Interest at CAS 05-99-04, Burn Pits . . . . . . A-58

A.10-1 Sampling Location at CAS 22-99-04, Radioactive Waste Dump........... A-63

A.11-1 Sampling Locations at CAS 23-17-01,

Hazardous Waste Storage Area (Surface Area) . . . . . . . . . . . . . A-68

A.11-2 Sampling Locations at CAS 23-17-01, Hazardous Waste Storage Area (Landfill Area) . . . . . . . . . . . . . . . A-69

A.11-3 Excavation Locations at CAS 23-17-01, Hazardous Waste Storage Area (Landfill Area) $64 \ldots \ldots \ldots \ldots \ldots \ldots$. . . . . . . . . . 


\section{List of Tables}

Number

Title

Page

3-1 Corrective Action Alternatives for CAU 140 CASs ................. 23

3-2 Detailed Evaluation of Alternatives for Corrective Action Unit 140. . . . . . . . 31

3-3 Comparative Evaluation of Alternatives for Corrective Action Unit 140 . . . . . . . . . . . . . . . . . . . . . . . . . . . . . 33

A.2-1 Laboratory Analytical Parameters and Methods, CAU 140 Investigation Samples ........................ A-11

A.3-1 Samples Collected at CAS 05-08-01, Detonation Pits............... A-16

A.3-2 Soil Sample Results for Total VOCs Detected

Above Minimum Reporting Limits at CAS 05-08-01 ............... A-18

A.3-3 Soil Sample Results for Total SVOCs Detected

Above Minimum Reporting Limits at CAS 05-08-01 .............. A-18

A.3-4 Soil Sample Results for Total RCRA Metals Detected

Above Minimum Reporting Limits at CAS 05-08-01 . . . . . . . . . . . A-19

A.3-5 Soil Samples Results for Explosives Detected

Above Minimum Reporting Limits at CAS 05-08-01 .............. A-20

A.3-6 Soil Sample Results for Gamma-Emitting Radionuclides Detected

Above Minimum Reporting Limit at CAS 05-08-01 ................ A-21

A.3-7 Soil Sample Results for Isotopes Detected

Above Minimum Reporting Limits at CAS 05-08-01 .............. A-23

A.4-1 Samples Collected at CAS 05-08-02, Debris Pits $\ldots \ldots \ldots \ldots \ldots \ldots$ A-25

A.4-2 Soil Sample Results for Total VOCs Detected

Above Minimum Reporting Limits at CAS 05-08-02 ............. A-28

A.4-3 Soil Sample Results for TPH-DRO Detected

Above Minimum Reporting Limits at CAS 05-08-02 . . . . . . . . . . . A-29 


\section{List of Tables (Continued)}

A.4-4 Soil Sample Results for Total RCRA Metals

Detected Above Minimum Reporting Limits at CAS 05-08-02 . . . . . . . . . . A-29

A.5-1 Samples Collected at CAS 05-17-01, Hazardous Waste Accumulation Site (Buried)

A.5-2 Soil Sample Results for Metals Detected

Above Minimum Reporting Limits at CAS 05-17-01 . . . . . . . . . . . A-35

A.6-1 Samples Collected at CAS 05-19-01, Waste Disposal Site . . . . . . . . . . A-39

A.6-2 Soil Sample Results for Total VOCs Detected

Above Minimum Reporting Limits at CAS 05-19-01 . . . . . . . . . . . . A-41

A.6-3 Soil Sample Results for Total RCRA Metals Detected

Above Minimum Reporting Limits at CAS 05-19-01 . . . . . . . . . . . . . . . A-43

A.6-4 Soil Sample Results for Gamma-Emitting Radionuclides

Detected Above Minimum Reporting Limits at CAS 05-19-01 . . . . . . . . . A-44

A.6-5 Soil Sample Results for Isotopes Detected

Above Minimum Reporting Limits at CAS 05-19-01 . . . . . . . . . . . . . A-45

A.7-1 Samples Collected at CAS 05-23-01, Gravel Gertie . . . . . . . . . . . . A-48

A.7-2 Soil Sample Results for Gamma-Emitting Radionuclides

Detected Above Minimum Reporting Limits at CAS 05-23-01

A.7-3 Soil Sample Results for Isotopes Detected

Above Minimum Reporting Limits at CAS 05-23-01 . . . . . . . . . . . . . . . A A-50

A.8-1 Samples Collected at CAS 05-35-01, Burn Pit . . . . . . . . . . . A-54

A.8-2 Soil Sample Results for Total VOCs Detected

Above Minimum Reporting Limits at CAS 05-35-01 . . . . . . . . . . . . A A-55

A.8-3 Soil Sample Results for Total RCRA Metals Detected

Above Minimum Reporting Limits at CAS 05-35-01 . . . . . . . . . . . A A-56 


\section{List of Tables (Continued)}

Number

Title

Page

A.9-1 Samples Collected at CAS 05-99-04, Burn Pit ................. A-59

A.9-2 Soil Sample Results for TPH-DRO Detected

Above Minimum Reporting Limits at CAS 05-99-04 . . . . . . . . . . . . A-60

A.9-3 Soil Sample Results for Total RCRA Metals Detected

Above Minimum Reporting Limits at CAS 05-99-04 . ................ A-61

A.10-1 Samples Collected at CAS 22-99-04, Radioactive Waste Dump. ........... A-64

A.10-2 Soil Sample Results for Gamma-Emitting Radionuclides

Detected Above Minimum Reporting Limits at CAS 22-99-04 . . . . . . . . . A A-65

A.10-3 Soil Sample Results for Gross Beta Detected

Above Minimum Reporting Limits at CAS 22-99-04 . . . . . . . . . . . A-65

A.11-1 Samples Collected at CAS 23-17-01, Hazardous Waste Storage Area . . . . . . A A-70

A.11-2 Geotechnical Data and Laboratory Analytical Methods for CAS 23-17-01 . . . A-77

A.11-3 Soil Sample Results for Total VOCs Detected Above

Minimum Reporting Limits at CAS $23-17-01 \ldots \ldots \ldots \ldots \ldots \ldots \ldots \ldots \ldots \ldots$

A.11-4 Soil Sample Result for Total SVOCs Detected Above

Minimum Reporting Limits at CAS $23-17-01 \ldots \ldots \ldots \ldots \ldots \ldots \ldots . . . . . . .79$

A.11-5 Soil Sample Results for TPH-DRO

Detected Above Minimum Reporting Limits at CAS 23-17-01 . ........ A-80

A.11-6 Soil Sample Results for Total RCRA Metals

Detected Above Minimum Reporting Limits at CAS 23-17-01 . . . . . . . . . A-81

A.11-7 Soil Sample Result for PCBs Detected

Above Minimum Reporting Limits at CAS $23-17-01 \ldots \ldots \ldots \ldots \ldots \ldots$ A-83

A.11-8 Soil Sample Results for Pesticides Detected

Above Minimum Reporting Limits at CAS 23-17-01 .............. A-84

B.1-1 Organic Chemical Precision Measurements for CAU $140 \ldots \ldots \ldots \ldots \ldots$. 


\section{List of Tables (Continued)}

Number

Title

Page

B.1-2 Inorganic Chemical Precision Measurements for CAU $140 \ldots \ldots \ldots \ldots \ldots$. . . 5

B.1-3 TCLP Chemical Precision Measurements for CAU $140 \ldots \ldots \ldots \ldots \ldots$. . . . 6

B.1-4 Laboratory Duplicate Precision $\ldots \ldots \ldots \ldots \ldots \ldots \ldots \ldots \ldots \ldots \ldots \ldots \ldots \ldots$

B.1-5 Laboratory MS/MSD Precision $\ldots \ldots \ldots \ldots \ldots \ldots \ldots \ldots \ldots \ldots \ldots . .6$

B.1-6 Field Duplicate Precision . . . . . . . . . . . . . . . . . . .

B.1-7 Organic Laboratory Accuracy Measurements for CAU $140 \ldots \ldots \ldots \ldots$ B-13

B.1-8 Inorganic Laboratory Accuracy Measurements for CAU $140 \ldots \ldots \ldots \ldots$. . . 14

B.1-9 TCLP Laboratory Accuracy Measurements for CAU $140 \ldots \ldots \ldots \ldots$. . . . 14

B.1-10 Radioanalytical Laboratory Control Sample (LCS) Accuracy . . . . . . . . . B B-16

B.1-11 Radioanalytical Matrix Spike (MS) Accuracy.................. B-16

B.1-12 Organic Chemical Completeness for CAU $140 \ldots \ldots \ldots \ldots \ldots \ldots \ldots$ B-18

B.1-13 Inorganic Chemical Completeness for CAU $140 \ldots \ldots \ldots \ldots \ldots \ldots \ldots$. 19

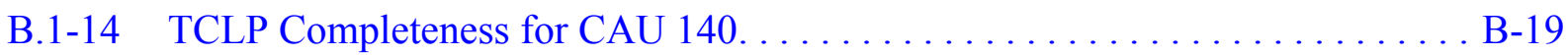

B.1-15 Radiological Completeness for CAU $140 \ldots \ldots \ldots \ldots \ldots \ldots \ldots \ldots$ B-20

B.1-16 CAU 140 Rejected Data for CAS $05-08-01 \ldots \ldots \ldots \ldots \ldots \ldots \ldots \ldots . . \ldots \ldots$

B.1-17 CAU 140 Rejected Data for CAS 05-08-02 ................... B-22

B.1-18 CAU 140 Rejected Data for CAS $05-17-01 \ldots \ldots \ldots \ldots \ldots \ldots \ldots \ldots . \ldots \ldots$

B.1-19 CAU 140 Rejected Data for CAS $05-35-01 \ldots \ldots \ldots \ldots \ldots \ldots \ldots \ldots . . \ldots \ldots$

B.1-20 CAU 140 Rejected Data for CAS $23-17-01 \ldots \ldots \ldots \ldots \ldots \ldots \ldots \ldots \ldots \ldots \ldots$

D.1-1 Sample Location Coordinates for CAS 05-08-01, Sample Locations and Points of Interest $\ldots \ldots \ldots \ldots \ldots \ldots \ldots \ldots \ldots \ldots \ldots \ldots \ldots$ 


\section{List of Tables (Continued)}

Number

Title

Page

D.1-2 Sample Location Coordinates for CAS 05-08-02,

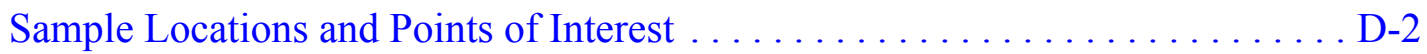

D.1-3 Sample Location Coordinates for CAS 05-17-01,

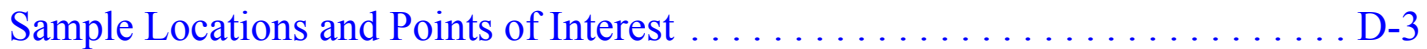

D.1-4 Sample Location Coordinates for CAS 05-19-01, Sample Locations and Points of Interest $\ldots \ldots \ldots \ldots \ldots \ldots \ldots \ldots \ldots \ldots \ldots \ldots \ldots$

D.1-5 Sample Location Coordinates for CAS 05-23-01, Sample Locations and Points of Interest $\ldots \ldots \ldots \ldots \ldots \ldots \ldots \ldots \ldots \ldots \ldots \ldots$

D.1-6 Sample Location Coordinates for CAS 05-35-01, Sample Locations and Points of Interest . . . . . . . . . . . . . . . . D-4

D.1-7 Sample Location Coordinates for CAS 05-99-04, Sample Locations and Points of Interest $\ldots \ldots \ldots \ldots \ldots \ldots \ldots \ldots \ldots \ldots \ldots \ldots$

D.1-8 Sample Location Coordinates for CAS 22-99-01, Sample Locations and Points of Interest ................... D-5

D.1-9 Sample Location Coordinates for CAS 23-17-01, Samples Locations and Points of Interest $\ldots \ldots \ldots \ldots \ldots \ldots \ldots \ldots \ldots \ldots \ldots \ldots$ 


\section{List of Acronyms and Abbreviations}

$\begin{array}{ll}\text { ALARA } & \text { As-low-as-reasonably-achievable } \\ \text { AM } & \text { Americium } \\ \text { bgs } & \text { Below ground surface } \\ \text { BN } & \text { Bechtel Nevada } \\ \text { CADD } & \text { Corrective Action Decision Document } \\ \text { CAI } & \text { Corrective Action Investigation } \\ \text { CAIP } & \text { Corrective Action Investigation Plan } \\ \text { CAS } & \text { Corrective Action Site } \\ \text { CAU } & \text { Corrective Action Unit } \\ \text { CFR } & \text { Code of Federal Regulations } \\ \text { CLP } & \text { Contract Laboratory Program } \\ \text { cm } & \text { Centimeter } \\ \text { cm } & \text { Electrical imaging } \\ \text { Co } & \text { Square centimeter } \\ \text { COC } & \text { Cobalt } \\ \text { COPC } & \text { Contaminants of concern } \\ \text { CRDL } & \text { Contaminants of potential concern } \\ \text { Cs } & \text { Contract required detection limit } \\ \text { CSM } & \text { Cesium } \\ \text { DOE } & \text { Conceptual site model } \\ \text { DQI } & \text { Disintegrations per minute } \\ \text { DA } & \text { Datality objective } \\ \text { DAssembly, and disassembly }\end{array}$




\section{List of Acronyms and Abbreviations (Continued)}

EPA U.S. Environmental Protection Agency

ETS-1 Engine Test Stand No. 1

ETSM Engine Transport System Maintenance

FADL Field activity daily $\log$

FD Field duplicate

FFACO Federal Facility Agreement and Consent Order

FRC Free-release criteria

FSL Field-screening level

FSR Field-screening results

$\mathrm{ft} \quad$ Foot (feet)

gal Gallon

GC Gas chromatograph

GPS Global positioning system

GRO Gasoline-range organics

HCIP Heavy cast-iron pipe

HE High explosives

HWAA Hazardous Waste Accumulation Area

HWSA Hazardous Waste Storage Area

ICP Inductively coupled plasma

IDL Instrument Detection Limit

IDW Investigation-derived waste

in. $\quad \operatorname{Inch}(\mathrm{es})$

LCS Laboratory control sample

LCSD Laboratory control sample duplicate

LD Laboratory duplicate

LDR Land disposal restrictions

m Meter




\section{List of Acronyms and Abbreviations (Continued)}

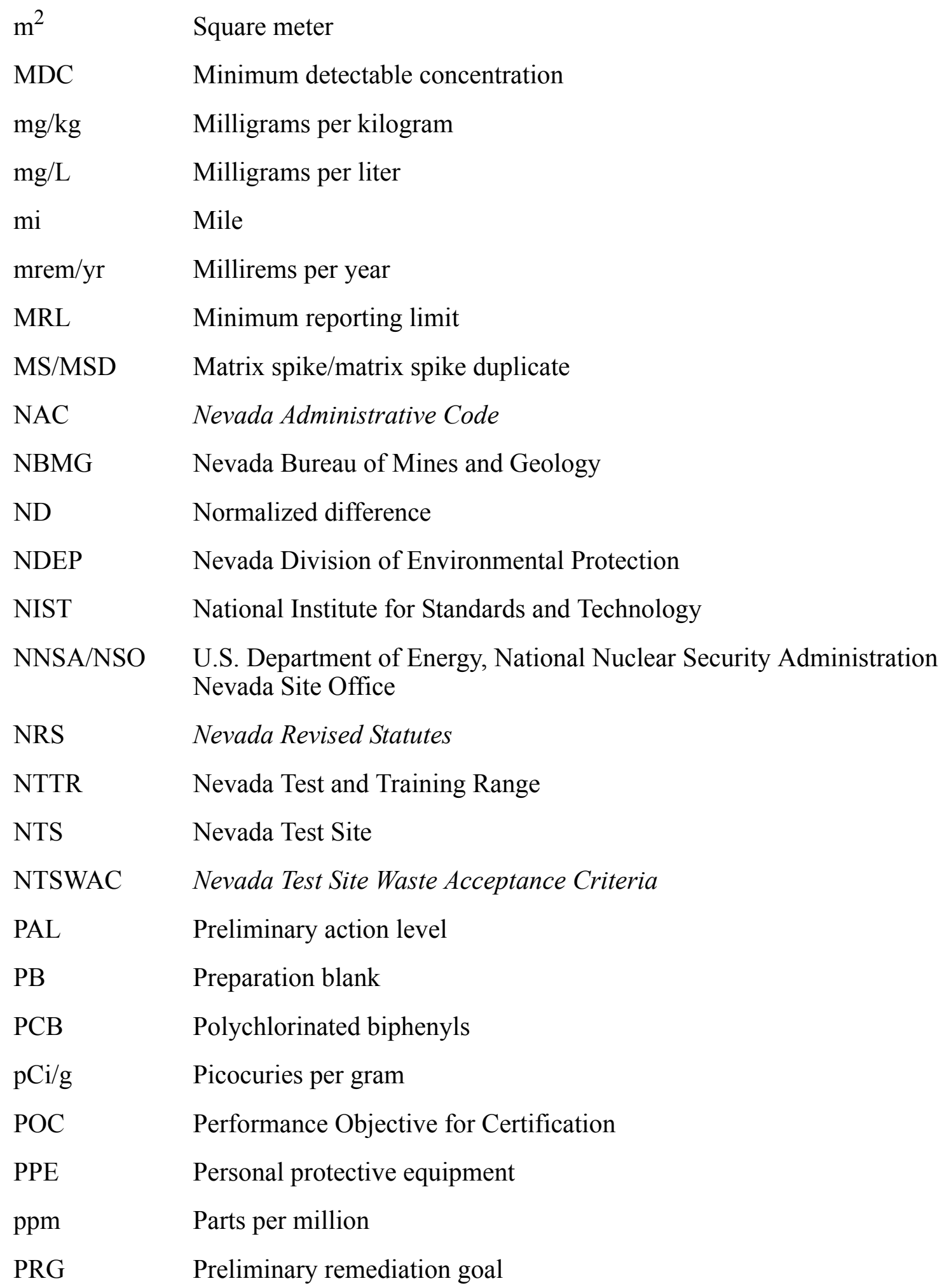




\section{List of Acronyms and Abbreviations (Continued)}

\begin{tabular}{|c|c|}
\hline $\mathrm{Pu}$ & Plutonium \\
\hline QA & Quality assurance \\
\hline QAPP & Quality Assurance Project Plan \\
\hline QC & Quality control \\
\hline $\mathrm{RCP}$ & Reactor Control Point \\
\hline RCRA & Resource Conservation and Recovery Act \\
\hline RDX & Royal Demolition Explosive \\
\hline RIDP & Radionuclide inventory and distribution program \\
\hline ROTC & Record of Technical Change \\
\hline RPD & Relative percent difference \\
\hline RRF & Relative response factors \\
\hline RWMS & Radioactive Waste Management Site \\
\hline SAA & Satellite Accumulation Area \\
\hline $\mathrm{SC}$ & Site characterization \\
\hline SCL & Sample collection log \\
\hline SDG & Sample delivery group \\
\hline Shaw & Shaw Environmental, Inc. \\
\hline SNL & Sandia National Laboratories \\
\hline $\mathrm{Sr}$ & Stronium \\
\hline SSHASP & Site-specific health and safety plan \\
\hline SVOC & Semivolatile organic compound \\
\hline Tc & Technetium \\
\hline TCLP & Toxicity characteristic leaching procedure \\
\hline TDA & Train Decontamination Area \\
\hline Th & Thorium \\
\hline ТPH & Total petroleum hydrocarbons \\
\hline
\end{tabular}




\section{List of Acronyms and Abbreviations (Continued)}

$\begin{array}{ll}\mathrm{U} & \text { Uranium } \\ \mathrm{UXO} & \text { Unexploded ordnance } \\ \mathrm{VCP} & \text { Vitrified clay pipe } \\ \mathrm{VOC} & \text { Volatile organic compound } \\ \mathrm{yd}^{3} & \text { Cubic yards } \\ \mu \mathrm{g} / \mathrm{kg} & \text { Micrograms per kilogram } \\ \mu \mathrm{g} / \mathrm{L} & \text { Micrograms per liter } \\ \% \mathrm{R} & \text { Percent recovery }\end{array}$




\section{Executive Summary}

This Corrective Action Decision Document has been prepared for Corrective Action Unit (CAU) 140: Waste Dumps, Burn Pits, and Storage Area, Nevada Test Site (NTS), Nevada, in accordance with the Federal Facility Agreement and Consent Order (1996). Corrective Action Unit 140 is located within Areas 5, 22, and 23 of the NTS and is comprised of the following corrective action sites (CASs):

- 05-08-01, Detonation Pits

- 05-08-02, Debris Pits

- 05-17-01, Hazardous Waste Accumulation Site (Buried)

- 05-19-01, Waste Disposal Site

- 05-23-01, Gravel Gertie

- 05-35-01, Burn Pit

- 05-99-04, Burn Pit

- 22-99-04, Radioactive Waste Dump

- 23-17-01, Hazardous Waste Storage Area

The purpose of this Corrective Action Decision Document is to identify and provide a rationale for the recommendation of a corrective action alternative for each CAS within CAU 140. Corrective action investigation activities were performed from November 13 through December 11, 2002. Additional sampling to delineate the extent of contaminants of concern (COCs) was conducted on February 4 and March 18 and 19, 2003. Corrective action investigation activities were performed as set forth in the Corrective Action Investigation Plan for Corrective Action Unit 140 (NNSA/NV, 2002a).

Analytes detected during the corrective action investigation were evaluated against appropriate preliminary action levels to identify COCs for each CAS. Assessment of the data generated from investigation activities revealed the following:

- CAS 05-08-01 contains the COCs lead and the radioisotopes thorium-234, uranium (U)-238, and U-235 in surface soils at sample location A05.

- CAS 05-23-01 did not identify any COCs during the field investigation; however, based on historical knowledge of activities at this site, the interior of the Gravel Gertie is considered contaminated with the COC uranium. 
- CAS 23-17-01 contains the COC total petroleum hydrocarbons (diesel-range organics) at location $\mathrm{J} 20$ at a depth of 9 to 10 feet below ground surface.

- No COCs were identified at CASs 05-08-02, 05-17-01, 05-19-01, 05-35-01, 05-99-04, and 22-99-04.

Based on the evaluation of analytical data from the corrective action investigation; review of future and current operations in Areas 5,22, and 23 of the NTS; and the detailed comparative analysis of the potential corrective action alternatives, the following corrective actions were selected for the CAU 140 CASs.

No Further Action is the preferred corrective action for CASs 05-08-02, 05-17-01, 05-19-01, 05-35-01, 05-99-04, and 22-99-04.

Clean Closure is the preferred corrective action for the following CAS:

- CAS 05-08-01 - Remove metal edging and COC-impacted soil around location A05.

Alternative 3, Closure-in-Place, is the preferred corrective action for the following sites:

- CAS 05-23-01 - Gravel Gertie

- CAS 23-17-01 - Hazardous Waste Storage Area

The preferred corrective action alternatives were evaluated on technical merit focusing on performance, reliability, feasibility, and safety. The alternatives were judged to meet all requirements for the technical components evaluated. The alternatives meet all applicable state and federal regulations for closure of the sites and will eliminate potential future exposure pathways to the contaminated media at CAU 140.

In addition to the closure activities outlined above, the surface debris at CASs 05-08-01, 05-08-02, 05-17-01, 05-19-01, and 05-99-04 will be removed and disposed as a best management practice during closure activities. 


\subsection{Introduction}

This Corrective Action Decision Document (CADD) has been prepared for Corrective Action Unit (CAU) 140: Waste Dumps, Burn Pits, and Storage Area, Nevada Test Site (NTS), Nevada, in accordance with the Federal Facility Agreement and Consent Order (FFACO) that was agreed to by the State of Nevada, U.S. Department of Energy (DOE), and the U.S. Department of Defense (FFACO, 1996). The NTS is approximately 65 miles (mi) northwest of Las Vegas, in Nye County, Nevada. The nine CASs within CAU 140 are shown on Figure 1-1. This CADD provides or references the specific information necessary to recommend corrective actions for the corrective action sites (CASs) of CAU 140 located within Areas 5, 22, and 23 of the NTS, as provided in the FFACO. The nine CASs are:

- $05-08-01$, Detonation Pits

- 05-08-02, Debris Pits

- 05-17-01, Hazardous Waste Accumulation Site (Buried)

- 05-19-01, Waste Disposal Site

- 05-23-01, Gravel Gertie

- 05-35-01, Burn Pit

- 05-99-04, Burn Pit

- 22-99-04, Radioactive Waste Dump

- 23-17-01, Hazardous Waste Storage Area

\subsection{Purpose}

The CAU consists of a variety of CASs, including detonation, debris, and burn pits, waste dumps, and a Gravel Gertie test structure and were used for testing, material storage, waste storage, and waste disposal. The following is a brief description of each CAS including changes resulting from investigation activities:

- CAS 05-08-01, Detonation Pits -- This CAS contains two surface detonation areas that measure approximately 4 by 15 feet (ft). Additionally, there are three trenches (3- to 4-ft deep) located at the far end of the CAS. Surface debris is scattered throughout the area.

- CAS 05-08-02, Debris Pits -- This CAS contains an area that resembles an evaporation pond. Surface debris is scattered throughout the area. 


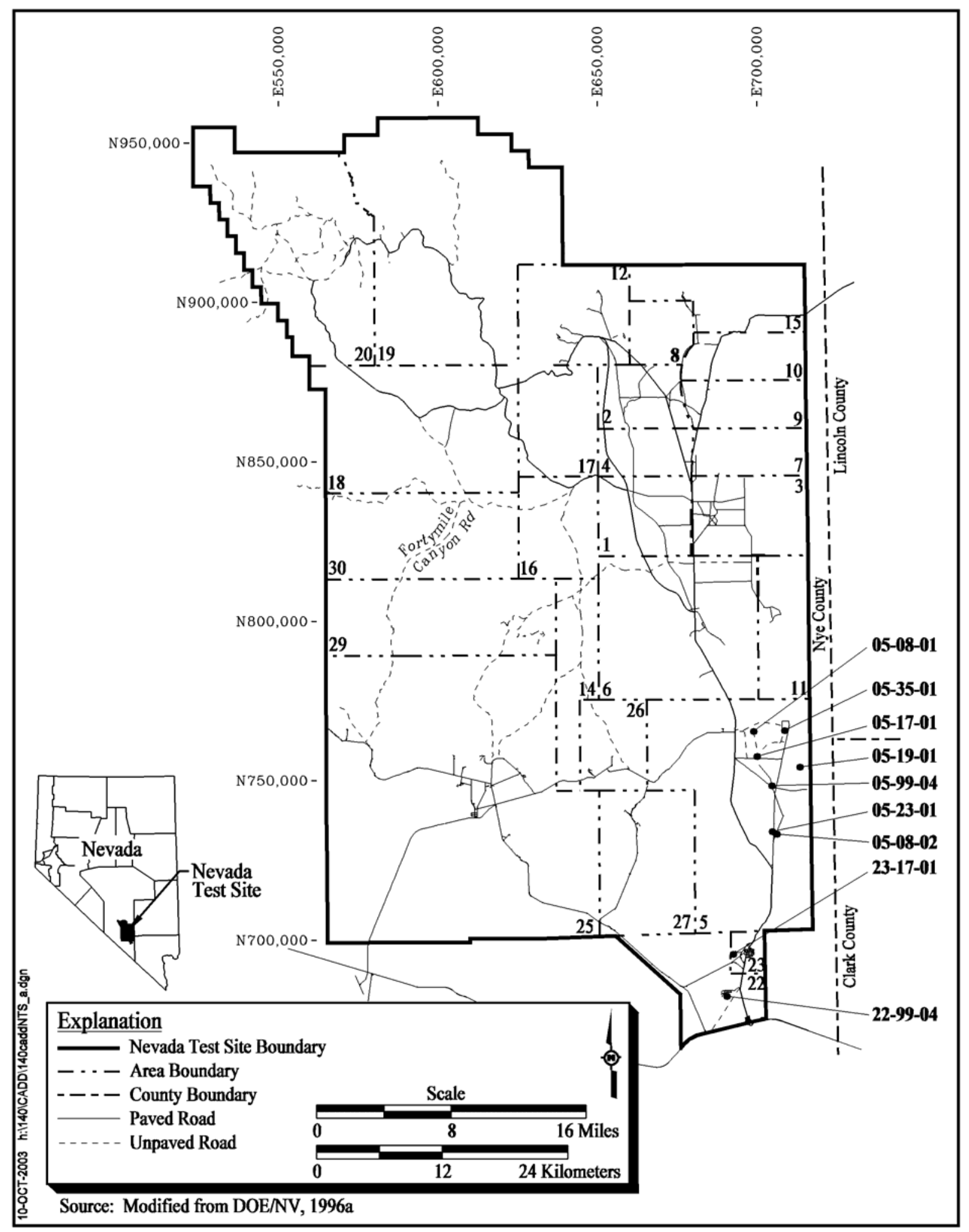

Figure 1-1 Nevada Test Site and CAU 140 Site Map 
- CAS 05-17-01, Hazardous Waste Accumulation Site (Buried) -- No buried debris was discovered at this CAS. A soil mound is located in the middle of the CAS, and a small amount of surface debris and staining is present.

- CAS 05-19-01, Waste Disposal Site -- This CAS consisted of three noncontiguous areas that contained large debris piles. The debris piles have been removed. There was no buried debris found beneath the middle debris pile during investigation activities. Small amounts of surface debris remain scattered throughout the area.

- CAS 05-23-01, Gravel Gertie -- This CAS consists of a test structure and surrounding area that may have been impacted by dispersion of contaminants. Debris associated with the structure is located at this CAS.

- CAS 05-35-01, Burn Pit -- This CAS has two burn stains at the surface.

- CAS 05-99-04, Burn Pit -- This CAS contains three surface burn areas and surface debris.

- CAS 22-99-04, Radioactive Waste Dump -- This CAS contains a bermed area of deteriorating sandbags. No debris is located at this CAS.

- CAS 23-17-01, Hazardous Waste Storage Area (HWSA) -- This CAS consists of a former hazardous waste storage area that has been covered over by gravel and is used as a parking lot. The CAS also has buried debris in a landfill. No surface debris is present.

This CADD develops and evaluates potential corrective action alternatives and provides a rationale for the selection of a recommended corrective action alternative for each CAS within CAU 140. The need for evaluation of corrective action alternatives is based on process knowledge and the results of investigative activities conducted in accordance with the Corrective Action Investigation Plan (CAIP). The Corrective Action Investigation Plan for Corrective Action Unit 140: Waste Dumps, Burn Pits, and Storage Area, Nevada Test Site, Nevada (NNSA/NV, 2002a), provides information relating to the history, planning, and scope of the investigation that will not be repeated in this CADD.

\subsection{Scope}

The scope of the activities used to justify and recommend a preferred corrective action alternative for each CAS within CAU 140 includes the following:

- Evaluation of current site conditions, including the concentration and extent of contaminants of concern (COCs) 
- Development of corrective action objectives commensurate with the complexity of each CAS

- Identification of corrective action alternative screening criteria

- Performance of detailed and comparative evaluations of corrective action alternatives in relation to corrective action objectives and screening criteria

\subsection{Corrective Action Decision Document Contents}

This CADD is divided into the following sections and appendices:

Section 1.0 - Introduction: Summarizes the purpose, scope, and contents of this CADD.

Section 2.0 - Corrective Action Investigation Summary: Summarizes the field investigation activities, the results of the investigation, and the need for corrective action at CAU 140.

Section 3.0 - Evaluation of Alternatives: Describes, identifies, and evaluates the steps taken to determine a preferred corrective action alternative for each CAS.

Section 4.0 - Recommended Alternatives: Presents the preferred corrective action alternative for each CAS and the rationale based on the corrective action objectives and screening criteria.

Section 5.0 - References: Provides a list of all references in the preparation of this CADD.

Appendix A - Corrective Action Investigation Report for CAU 140: Provides a description of the project objectives, field investigation and sampling activities, investigation results, waste management, and quality assurance practices.

Appendix B - Data Assessment for CAU 140: Provides an assessment of data obtained during the CAU 140 investigation. Also summarizes and compares the investigation results to the requirements set forth during the data quality objective (DQO) process.

Appendix C - Cost Estimates for CAU 140: Presents cost estimates for the construction, operation, and maintenance of each corrective action alternative evaluated for each CAS within CAS 140.

Appendix D - Sample Location Coordinates for CAU 140: Provides coordinates for investigation sample locations and system features. 
Appendix E - Evaluation of Risk

Appendix F - Project Organization for CAU 140: Identifies the U.S. Department of Energy, National Nuclear Security Administration Nevada Site Office (NNSA/NSO) CAU 140 Project Manager and other appropriate personnel involved with the CAU 140 characterization and closure activities for each CAS.

Appendix G - NDEP Comment Responses: Contains responses to Nevada Division of Environmental Protection (NDEP) comments on the Draft CADD.

The field investigation was performed in accordance with the following documents:

- CAU 140 CAIP (NNSA/NV, 2002a)

- Industrial Sites Quality Assurance Project Plan (QAPP) (NNSA/NV, 2002b)

- FFACO (1996)

- Project Management Plan (DOE/NV, 1994) 


\subsection{Corrective Action Investigation Summary}

The following sections summarize the CAU 140 investigation activities, investigation results, and identify the need for corrective action at each CAS. Detailed investigation activities and results for CAU 140 are presented in Appendix A of this document.

\subsection{Investigation Activities}

Corrective action investigation activities were performed as set forth in the CAU 140 CAIP (NNSA/NV, 2002a) from November 13 through December 11, 2002. Additional sampling to delineate the extent of COCs was conducted on February 4 and March 18 and 19, 2003. The purpose of the investigation was to:

- Identify the presence and nature of contaminants of potential concern (COPCs).

- Determine whether COPCs exceed preliminary action levels (PALs), thereby becoming COCs.

- Determine the vertical and lateral extent of COCs, if present.

- Ensure adequate data have been collected to close the sites under the Nevada Division of Environmental Protection (NDEP), Resource Conservation and Recovery Act (RCRA), and DOE requirements.

Sufficient information was obtained to develop, evaluate, and recommend corrective action alternatives for each CAS located within CAU 140. The scope of the corrective action investigation for CAU 140 included the following activities to address the decision statements:

- Removed surface materials at CASs 05-19-01 and 05-08-02.

- At CAS 23-17-01, penetrated the disposal feature (landfill) cover via excavation to make direct measurements of the cover thicknesses. Performed a topographic survey to determine the slope of the cover and collect soil samples for the analysis of geotechnical properties of the cover and base of the landfill.

- Conducted exploratory excavations to confirm buried debris is not present at CASs 05-19-01, 05-17-01, and 05-08-01. 
- Field-screened selected soil samples for volatile organic compounds (VOCs) and alpha and beta/gamma radiation

- Collected and analyzed soil samples to determine lateral and vertical extent of COCs, as appropriate

- Collected Global Positioning System (GPS) coordinates at sample locations and points of interest at each CAS

- Collected and analyzed samples of investigation-derived waste (IDW), as needed, to ensure full characterization of each CAS

\section{Conceptual Site Models}

Conceptual site models (CSMs) were developed for each CAS as provided in the CAIP. The system configurations observed at each CAS were consistent with those provided in the CAIP. Results of the investigation validate the CSMs outlined in the CAIP (NNSA/NV, 2002a). Appendix B discusses each of the CSMs. Section 2.1.1 through Section 2.1.9 summarize the investigative activities conducted at each of the CAU 140 CASs.

\subsubsection{Detonation Pits (CAS 05-08-01)}

The following investigative field work was conducted at CAS 05-08-01:

- A total of 12 soil samples were collected at this CAS. Six were from surface (0 to $1 \mathrm{ft})$ locations as specified in the CAIP. Samples were also collected at two step-out locations at 0 to $1 \mathrm{ft}$ and 2 to $3 \mathrm{ft}$ below ground surface (bgs) and at two of the original surface sample location from 2 to $3 \mathrm{ft}$ bgs.

- Soil samples were field screened for VOCs and alpha and beta/gamma radiation. Results were compared to the field-screening levels (FSLs).

- Excavation with a backhoe was used to explore the subsurface area beneath the gravel pile in the central area of the CAS. There was no debris found within or beneath the gravel.

- Soil samples were shipped to an off-site laboratory for analyses outlined in Table A.3-1.

Investigation activities associated with CAS 05-08-01 are further detailed in Section A.3.0. 


\subsubsection{Debris Pits (CAS 05-08-02)}

The following investigative field work was conducted at CAS 05-08-02:

- A total of 11 soil samples were collected at this CAS. Eight were from surface ( 0 to $1 \mathrm{ft}$ ) locations as specified in the CAIP. Two locations also had samples collected from 3 to $4 \mathrm{ft}$ bgs as specified in the CAIP. The eleventh sample was collected from 1 to $1.5 \mathrm{ft}$ bgs. In addition, one laboratory quality control (QC) and one field duplicate was collected and analyzed.

- A power auger was used to access the sample horizon from 3 to $4 \mathrm{ft}$ bgs, then the sample was collected by hand using a disposable scoop.

- Soil samples were field screened for VOCs and alpha and beta/gamma radiation. Results were compared to the FSLs.

- Soil samples were shipped to an off-site laboratory for analyses outlined in Table A.4-1.

Investigation activities associated with CAS 05-08-02 are further detailed in Section A.4.0.

\subsubsection{Hazardous Waste Accumulation Site (Buried) (CAS 05-17-01)}

The following investigative field work was conducted at CAS 05-17-01:

- A total of five soil samples were collected at this CAS. All samples were from discolored soil at surface ( 0 to $1 \mathrm{ft}$ ) locations as specified in the CAIP. Samples were not collected at any step-out locations. These five soil samples were submitted for laboratory analyses. In addition, one QC field blank was collected and analyzed. The soil samples were collected by hand using a disposable scoop.

- Excavation with a backhoe was used to explore the subsurface area beneath the gravel/dirt pile in the central area of the CAS. There was no debris found within or beneath the gravel. No additional samples were collected based on these excavations.

- Soil samples were field screened for VOCs and alpha and beta/gamma radiation. Results were compared to the FSLs.

- Soil samples were shipped to an off-site laboratory for analyses outlined in Table A.5-1.

Investigation activities associated with CAS 05-17-01 are further detailed in Section A.5.0. 


\subsubsection{Waste Disposal Site (CAS 05-19-01)}

No variations to the waste disposal site configuration were identified; however, no buried debris was present. The CSM remains valid for this CAS. The following investigative field work was conducted at CAS 05-19-01:

- Hand sampling was conducted using disposable scoops to access surface (0 to $1 \mathrm{ft}$ bgs) horizons and collect samples at the seven biased locations presented in the CAIP. Three of these locations had subsurface ( 4 to $5 \mathrm{ft}$ bgs) samples collected using a backhoe. In addition, one background sample was collected north and outside of the CAS boundary to assess background conditions and see if COCs were present that were not related to this CAS. A total of 11 soil samples were collected at this CAS. Samples were not collected at any step-out locations. These soil samples were submitted for laboratory analyses. In addition, one QC source blank and two field duplicates were collected and analyzed.

- Excavation with a backhoe was used to explore the subsurface area beneath the removed middle debris pile in the central area of the CAS. There was no debris found beneath the former location of the debris pile. No additional samples were collected based on these excavations.

- Soil samples were field screened for VOCs and alpha and beta/gamma radiation. Readings were compared to the FSLs.

- Soil samples were shipped to an off-site laboratory for analyses outlined in Table A.6-1.

Investigation activities associated with CAS 05-19-01 are further detailed in Section A.6.0.

\subsubsection{Gravel Gertie (CAS 05-23-01)}

The following investigative field work was conducted at CAS 05-23-01:

- Hand sampling was conducted using disposable scoops to access the surface (0 to $1 \mathrm{ft}$ bgs) horizon and collect samples at the five biased locations presented in the CAIP. A total of five soil samples were collected at this CAS. Samples were not collected at any step-out locations or at subsurface horizons. All soil samples were submitted for laboratory analyses.

- Soil samples were field screened for VOCs and alpha and beta/gamma radiation. Readings were compared to the FSLs.

- Soil samples were shipped to an off-site laboratory for analyses outlined in Table A.7-1.

Investigation activities associated with CAS 05-23-01 are further detailed in Section A.7.0. 


\subsubsection{Burn Pit (CAS 05-35-01)}

The following investigative field work was conducted at CAS 05-35-01:

- Eight surface and subsurface soil samples ( 0 to $1 \mathrm{ft}$ and 3 to $4 \mathrm{ft}$ bgs) were collected at four locations. During sample collection at two locations, a dark staining was observed from 0 to $0.5 \mathrm{ft}$ bgs. Deeper samples were collected at these locations below any apparent staining. All samples were sent to the laboratory for analysis.

- Soil samples were field screened for VOCs and alpha and beta/gamma radiation. Results were compared to the FSLs.

- Soil samples were shipped to an off-site laboratory for analyses outlined in Table A.8-1.

Investigation activities associated with CAS 05-35-01 are further detailed in Section A.8.0.

\subsubsection{Burn Pit (CAS 05-99-04)}

The following investigative field work was conducted at CAS 05-99-04:

- Surface soil (0 to $1 \mathrm{ft}$ bgs) sample locations were chosen from three surface burn areas as specified in the CAIP. All three samples were sent to the laboratory for analysis. In addition, one equipment rinsate sample was collected and analyzed. Samples were collected using a disposable scoop.

- Soil samples were field screened for VOCs and alpha and beta/gamma radiation. Results were compared to the FSLs.

- Soil samples were shipped to an off-site laboratory for analyses outlined in Table A.9-1.

Investigation activities associated with CAS 05-99-04 are further detailed in Section A.9.0.

\subsubsection{Radioactive Waste Dump (CAS 22-99-04)}

The following investigative field work was conducted at CAS 22-99-04:

- Hand sampling was conducted using a disposable scoop to access the surface (0 to $1 \mathrm{ft}$ bgs) horizon and collect a sample at the biased location presented in the CAIP. A total of one soil sample was collected at this CAS. This soil sample was submitted for laboratory analyses. 
- This soil sample was field screened for VOCs and alpha and beta/gamma radiation. Readings were compared to the FSLs.

- Soil samples were shipped to an off-site laboratory for analyses outlined in Table A.10-1.

Investigation activities associated with CAS 22-99-04 are further detailed in Section A.10.0.

\subsubsection{Hazardous Waste Storage Area (CAS 23-17-01)}

The following investigative field work was conducted at CAS 23-17-01:

- A backhoe was used to access the surface ( 0 to $1 \mathrm{ft}$ bgs) and subsurface (4 to $5 \mathrm{ft}$ bgs) horizons at the HWSA. Sixteen soil samples were collected by hand from the backhoe bucket using a disposable scoop.

- Thirty samples were collected just outside the perimeter of the landfill with a rotosonic drill rig at three soil horizons from 4 to $5 \mathrm{ft}, 9$ to $10 \mathrm{ft}$, and 14 to $15 \mathrm{ft} \mathrm{bgs}$.

- In addition, the geophysics survey conducted prior to the field investigation indicated an area of elevated conductivity adjacent to the HWSA. Eighteen samples were collected from the elevated conductivity area with a rotosonic drill rig. Two locations were planned and sampled from 9 to $10 \mathrm{ft}$ and 14 to $15 \mathrm{ft}$ bgs. One of these locations had total petroleum hydrocarbons (TPH) diesel-range organics (DRO) concentrations above PALs at 9 to $10 \mathrm{ft}$ bgs, so samples were also collected from 0 to $1 \mathrm{ft}$ and 4 to $5 \mathrm{ft}$ bgs at this location. Three step-out borings were conducted around this location and sampled from 0 to $1 \mathrm{ft}, 4$ to $5 \mathrm{ft}, 9$ to $10 \mathrm{ft}$, and 14 to $15 \mathrm{ft}$ bgs horizons.

- Ten exploratory excavations were dug to define the landfill dimensions (Figure A.11-3).

- Geotechnical samples were collected from the landfill cap and the native soil beneath the landfill.

- A topographic survey of the landfill surface was conducted to determine drainage patterns.

- Soil samples were field screened for VOCs, TPH, and alpha and beta/gamma radiation. Readings were compared to the FSLs.

- Soil samples were shipped to an off-site laboratory for analyses outlined in Table A.11-1.

Investigation activities associated with CAS 23-17-01 are further detailed in Section A.11.0. 


\subsection{Results}

A summary of characterization data from the corrective action investigation are provided in Section 2.2.1. This information illustrates the degree of characterization accomplished through the field effort and identifies those COPCs that exceeded PALs for soil. Section 2.2.2 summarizes the assessment made in Appendix B, which demonstrates the correlation between the investigation results and the DQOs.

\subsubsection{Summary of Characterization Data}

Chemical and radiological results for characterizing sample concentrations exceeding PALs in each of the CASs are presented in Section 2.2.1.1 through Section 2.2.1.9. The PALs for the CAU 140 investigation were identified during the DQO process. For chemical COPCs, PALs are based on U.S. Environmental Protection Agency (EPA) Region 9 Industrial Preliminary Remediation Goals (PRGs) (EPA, 2000), background concentrations for metals, and 100 milligrams per kilogram $(\mathrm{mg} / \mathrm{kg}$ ) for TPH. Radionuclide concentrations measured in CAU 140 environmental samples were compared to isotope-specific PALs. A radionuclide PAL is defined as the maximum concentration in an environmental sample taken from an undisturbed background location in the vicinity of the NTS and throughout the state of Nevada or the minimum detectable concentration (MDC) if the isotope is not reported or reported below the MDC (NNSA/NV, 2002a). If a sample had a positive concentration for any radionuclide with a corresponding PAL, the sample result and its PAL concentration data were statistically compared. The normalized difference test was used for this comparison. The test is defined as:

$$
\mathrm{t}=\frac{\mathrm{R}-\mathrm{PAL}}{\sqrt{\sigma_{\mathrm{R}^{2}}+\sigma_{\mathrm{PAL}}}}
$$

where:

$\mathrm{t} \quad=$ Normalized Difference Result

$\mathrm{R} \quad=$ Sample Radioanalytical Result

PAL $=$ Preliminary Action Level

$\sigma_{\mathrm{R}}^{2}=2$ Sigma Uncertainty in Radioanalytical Result

$\sigma_{\mathrm{PAL}}^{2}=2$ Sigma Uncertainty in PAL 
The statistical assumptions inherent to the normalized difference test are as follows:

- The sample counts are drawn from normally distributed populations.

- The counts for the sample and the PAL are centered on the sample result and the PAL.

- The width parameter of the distribution is equal to two sigma.

The "reasonable confidence" has been set to 95 percent for this comparison test. This means that for the sample radioanalytical result to statistically differ from the PAL (with a 95 percent confidence level), the normalized difference between the PAL and the sample radioanalytical result must be greater than or equal to 1.96. If the normalized difference is less than or equal to 1.96, the sample result and the PAL differ by less than or equal to a 5 percent level of significance. If the normalized difference is greater than 1.96, there is a 95 percent confidence that the result is greater than the PAL. The result is ultimately considered to be greater than the PAL if it is statistically different than the background based PAL.

Details about the methods used during the investigation and a comparison of environmental sample results to the PALs are presented in Appendix A. Sample locations that support the presence and/or extent of contamination at each site are shown in Appendix A figures. Based on these results, the nature and extent of COCs at CAU 140 have been adequately identified to develop and evaluate corrective action alternatives.

The corrective action investigation analytical results, organized by CAS, are summarized in the following sections.

\subsubsection{Detonation Pits (CAS 05-08-01)}

Analytical results for soil samples collected at this CAS indicated that COCs are present in the soil at this site.

The COCs lead and the radioisotopes thorium (Th)-234, uranium (U)-238, and U-235 were found in surface soils at location A05 (Figure A.3-1). The lead concentration decreased with depth to a concentration below PALs at 2 to $3 \mathrm{ft}$ bgs. The U-238 and U-235 concentration decreased with depth and was below PALs at 2 to $3 \mathrm{ft}$ bgs. The Th-234 concentration decreased with depth but was still above PALs at 2 to $3 \mathrm{ft}$ bgs; however, the concentration decreased by an order of magnitude within the 2 -ft interval. Based on the decrease in concentrations with depth, the Th-234 concentration is 
expected to be below PALs at a depth of approximately $4 \mathrm{ft}$ bgs. It is recommended that during closure activities a confirmation sample be collected to confirm no COCs remain at this location. Sample results from the step-out locations (A06, A07, and A08) indicate lead and radioisotope concentrations have not migrated more than $5 \mathrm{ft}$ laterally at concentrations that exceed the PALs.

Analytical results associated with CAS 05-08-01 are further detailed in Section A.3.0.

\subsubsection{Debris Pits (CAS 05-08-02)}

There were no COCs identified in the soil at this CAS.

\subsubsection{Hazardous Waste Accumulation Site (Buried) (CAS 05-17-01)}

There were no COCs identified in the soil at this CAS.

\subsubsection{Waste Disposal Site (CAS 05-19-01)}

There were no COCs identified in the soil at this CAS.

\subsubsection{Gravel Gertie (CAS 05-23-01)}

No COCs were identified in the soil at this CAS. Due to the physical constraints of the structure, it was not practical to collect samples from inside the Gravel Gertie. Historical radiological surveys and air monitoring of the Gravel Gertie experiments that have used uranium as a tracer material have not identified significant levels of external (to the structure) contamination. Based on the historical documentation, the Gravel Gertie internal structure is considered to be contaminated.

\subsubsection{Burn Pit (CAS 05-35-01)}

There were no COCs identified in the soil at this CAS.

\subsubsection{Burn PIt (CAS 05-99-04)}

There were no COCs identified in the soil at this CAS. 


\subsubsection{Radioactive Waste Dump (CAS 22-99-04)}

There were no COCs identified in the soil at this CAS.

\subsubsection{Hazardous Waste Storage Area (CAS 23-17-01)}

Total petroleum hydrocarbons were identified at $\mathrm{J} 20$ at a depth of 9 to $10 \mathrm{ft}$ bgs (Figure A.11-2). A sample was sent to the laboratory from 14 to $15 \mathrm{ft}$ bgs from this borehole and no hydrocarbons were detected above PALs. During step-out sampling another borehole was drilled next to J20 and samples were sent to the laboratory from 0 to $1 \mathrm{ft}$ and 4 to $5 \mathrm{ft}$ bgs. No COCs were detected at these horizons. Step-out sampling was conducted $15 \mathrm{ft}$ laterally from J20 at three locations: J21, J22, and J23. These three boreholes were sampled and analyzed from 0 to 1,4 to 5,9 to 10 , and 14 to $15 \mathrm{ft}$ depth. No COCs were found in any of these step-outs.

\subsubsection{Data Assessment Summary}

An assessment of CAU 140 investigation results determined that the data collected met the DQOs and supported its intended use in the decision-making process. This assessment, provided in Appendix B, includes an evaluation of the data quality indicators (DQIs) to determine the degree of acceptability and usability of the reported data in the decision-making process. Additionally, a reconciliation of the data with the CSMs established for this project was conducted. Conclusions were based on the results of the quality control measurements and are discussed in Section A.13.0 of Appendix A and also in Appendix B.

The overall results of the assessment indicate that the DQI goals for precision, accuracy, completeness, representativeness, and comparability have been achieved. Precision and accuracy of the datasets were demonstrated to be within acceptable limits for a high percentage of the data.

Completeness objectives for this CAU have been achieved. Rejected data were thoroughly reviewed and questions concerning these data have been addressed in Appendix B.

Representativeness of site characteristics was demonstrated with the CAU 140 data. An evaluation of comparability provides high confidence that the datasets for this project are comparable to other NTS projects and other data generated by accepted industry standards. The evaluation also ensures that 
project data are comparable to PALs and regulatory disposal limits. Data were analyzed per SW-846 protocol, meeting specifications noted in the CAIP (NNSA/NV, 2002a). Achieving all of the DQI goals supports acceptance of the CAU 140 datasets, thereby meeting the DQOs established for this project and the subsequent use of these data in the decision-making process.

\subsection{Need for Corrective Action}

Analytes detected during the corrective action investigation were evaluated against PALs to determine COCs for each CAS in CAU 140. The identification of COCs above PALs in surface and subsurface soil requires that corrective action alternatives be considered and evaluated. The impacted volume/characteristics and site-specific constraints are provided in each CAS-specific section. The corrective action alternatives are identified in Section 3.0 and evaluated for their ability to ensure protection of the public and the environment in accordance with Nevada Administrative Code (NAC) 445A (NAC, 2000c), feasibility, and cost effectiveness. Contaminants of concern were not identified during investigation activities but are assumed to be present within the Gravel Gertie at CAS 05-23-01. COCs were found during investigation activities at CASs 05-08-01 and 23-17-01 and are provided in the following sections.

\subsubsection{Detonation Pits (CAS 05-08-01)}

The COCs at this CAS have been identified as lead $(1,900 \mathrm{mg} / \mathrm{kg})$ and the radioisotopes Th-234, U-238, and U-235. Toxicity characteristic leaching procedure (TCLP) analysis of the soil sample that exceeded the PAL for lead indicated leachable lead at $4.3 \mathrm{mg} / \mathrm{L}$, which did not exceed the disposal regulation of 5.0 milligrams per liter (mg/L) (CFR, 2002). Approximately 15 cubic yards $\left(\mathrm{yd}^{3}\right)$ of contaminated soil are present at location A05 based on the step-out samples (Section A.3.3). This soil volume was also determined not to be low-level waste; therefore, disposal at a sanitary landfill is appropriate. There are no site-specific characteristics that would constrain remediation at this CAS.

\subsubsection{Gravel Gertie (CAS 05-23-01)}

No COCs were identified during sampling activities. Uranium is an expected contaminant since it was used as a tracer in experiments conducted at the Gravel Gertie. Based on the historical documentation, the entire Gravel Gertie structure (internally) is considered to be contaminated. Due to the large volume of material present and the historical significance of being listed for inclusion in 
the National Register of Historic Places (DRI, 1996), the Gravel Gertie is not being considered for clean closure but will be considered for administrative controls only.

\subsubsection{Hazardous Waste Storage Area (CAS 23-17-01)}

No COCs were identified around the landfill or at the HWSA. The COC TPH (DRO) was found in subsurface soils at location J20, which was sampled due to a elevated conductivity noted during a geophysical survey. Approximately $236 \mathrm{yd}^{3}$ of hydrocarbon-contaminated soil remain at this location.

There are no site-specific characteristics that would constrain remediation at this CAS. 


\subsection{Evaluation of Alternatives}

The purpose of this section is to present the corrective action objectives for CAU 140, describe the general standards and decision factors used to screen the corrective action alternatives, and develop and evaluate a set of corrective action alternatives that could be used to meet the corrective action objectives.

\subsection{Corrective Action Objectives}

The corrective action objectives are media-specific goals for protecting human health and the environment. Based on the potential exposure pathways, the following corrective action objectives have been identified for CAU 140:

- Prevent or mitigate the exposure to media containing COCs at concentrations exceeding PALs as defined in the CAIP (NNSA/NV, 2002a).

- Prevent the spread of COCs beyond each CAS.

As identified in the CAIP, the future use for the CAU is assumed to be industrial, similar to current use (DOE/NV, 1998). Conceptual site models were developed as part of the CAU 140 CAIP (NNSA/NV, 2002a). The models identified the potential exposure mechanism as disturbance (excavation) of contaminated soil by site workers. This implies a potential exposure pathway through ingestion of, inhalation of, and/or dermal contact with contaminated media under industrial scenarios.

Corrective Action Site 05-08-01 is approximately 1.1 mi northwest of Well UE-5c. Depth to groundwater for Water Well UE-5c is approximately $804 \mathrm{ft}$ bgs (DOE/NV, 1996b). Corrective Action Site 05-23-01 is approximately 1.9 mi south and west of Water Well 5C. The static water level in Water Well 5C is approximately $601 \mathrm{ft} \mathrm{bgs} \mathrm{(DOE/NV,} \mathrm{1996b).} \mathrm{Corrective} \mathrm{Action}$ Site 23-17-01 is approximately $0.4 \mathrm{mi}$ north of a sewage lagoon monitoring well. The static water level in the sewage lagoon monitoring well is approximately 1,165 ft bgs (DOE/NV, 1997). These factors, along with others presented in Section 3.3, support the determination that contaminant migration to groundwater is not considered to be an exposure pathway. 


\subsection{Screening Criteria}

The screening criteria used to evaluate and select the preferred corrective action alternatives are identified in the EPA Guidance on RCRA Corrective Action Decision Documents (EPA, 1991) and the Final RCRA Corrective Action Plan (EPA, 1994).

Corrective action alternatives will be evaluated based on four general corrective action standards and five remedy selection decision factors. All corrective action alternatives must meet the general standards to be selected for evaluation using the remedy selection decision factors.

The general corrective action standards are as follows:

- Protection of human health and the environment

- Compliance with media cleanup standards

- Control the source(s) of the release

- Compliance with applicable federal, state, and local standards for waste management

The remedy selection decision factors are as follows:

- Short-term reliability and effectiveness

- Reduction of toxicity, mobility, and/or volume

- Long-term reliability and effectiveness

- Feasibility

- Cost

\subsubsection{Corrective Action Standards}

The following text describes the corrective action standards used to evaluate the corrective action alternatives.

\section{Protection of Human Health and Environment}

Protection of human health and the environment is a general mandate of the RCRA statute (EPA, 1994). This mandate requires that the corrective action include any necessary protective measures. These measures may or may not be directly related to media cleanup, source control, or management of wastes. The corrective action alternatives are evaluated for the ability to meet corrective action objectives as defined in Section 3.1. 


\section{Compliance with Media Cleanup Standards}

Each corrective action alternative must have the ability to meet the proposed media cleanup standards as set forth in applicable state and federal regulations, and as specified in the CAIP (NNSA/NV, 2002a). For this CAU, EPA Region IX PRGs (EPA, 2000), which are derived from the Integrated Risk Information System, are the basis for establishing the PALs for chemical contaminants under NAC 445A.2272 (NAC, 2000c). Background concentrations for metals that exceed PRGs may be substituted for the PRGs. The PAL for petroleum substances in soil is $100 \mathrm{mg} / \mathrm{kg}$ in accordance with NAC 445A.2272 (NAC, 2000c). The PALs for radiological contaminants are based on area background concentrations. Laboratory results above PALs indicate the presence of COCs at levels that may require corrective action.

\section{Control the Source(s) of the Release}

An objective of a corrective action remedy is to stop further environmental degradation by controlling or eliminating additional releases that may pose a threat to human health and the environment. Unless source control measures are taken, efforts to clean up releases may be ineffective or, at best, will essentially involve a perpetual cleanup. Therefore, each corrective action alternative must use an effective source control program to ensure the long-term effectiveness and protectiveness of the corrective action.

\section{Comply with Applicable Federal, State, and Local Standards for Waste Management}

During implementation of any corrective action alternative, all waste management activities must be conducted in accordance with applicable state and federal regulations (e.g., Nevada Revised Statutes [NRS] 459.400-459.600, "Disposal of Hazardous Waste" [NRS, 1998]; 40 Code of Federal Regulations [CFR] 260-282, "RCRA Regulations” [CFR, 2002a]; 40 CFR 761.61, "PCB Remediation Waste" [CFR, 2002b]; NAC 444, "Sanitation” [NAC, 2000a]; and NAC 459.9974, "Disposal and Evaluation of Contaminated Soil" [NAC, 2000d]). The requirements for management of the waste, if any, derived from the corrective action will be determined based on applicable state and federal regulations, field observations, process knowledge, characterization data, and data collected and analyzed during corrective action implementation. Administrative controls (e.g., decontamination procedures and corrective action strategies) will minimize waste generated during site corrective action activities. Decontamination activities will be performed in accordance with approved procedures and will be designated according to the COCs present at the site. 


\subsubsection{Remedy Selection Decision Factors}

The following text describes the remedy selection decision factors used to evaluate the corrective action alternatives.

\section{Short-Term Reliability and Effectiveness}

Each corrective action alternative must be evaluated with respect to its effects on human health and the environment during implementation of the corrective action. The following factors will be addressed for each alternative:

- Protection of the community from potential risks associated with implementation, such as fugitive dusts, transportation of hazardous materials, and explosion

- Protection of workers during implementation

- Environmental impacts that may result from implementation

- The amount of time until the corrective action objectives are achieved

\section{Reduction of Toxicity, Mobility, and/or Volume}

Each corrective action alternative must be evaluated for its ability to reduce the toxicity, mobility, and/or volume of the contaminated media. Reduction in toxicity, mobility, and/or volume refers to changes in one or more characteristics of the contaminated media by the use of corrective measures that decrease the inherent threats associated with that media.

\section{Long-Term Reliability and Effectiveness}

Each corrective action alternative must be evaluated in terms of risk remaining at the CAU after the corrective action alternative has been implemented. The primary focus of this evaluation is on the extent and effectiveness of the control that may be required to manage the risk posed by treatment residuals and/or untreated wastes. 


\section{Feasibility}

The feasibility criterion addresses the technical and administrative feasibility of implementing a corrective action alternative and the availability of services and materials needed during implementation. Each corrective action alternative must be evaluated for the following criteria:

- $\quad$ Construction and Operation. Refers to the feasibility of implementing a corrective action alternative given the existing set of waste and site-specific conditions.

- $\quad$ Administrative Feasibility. Refers to the administrative activities needed to implement the corrective action alternative (e.g., permits, public acceptance, rights of way, off-site approval).

- $\quad$ Availability of Services and Materials. Refers to the availability of adequate off-site and on-site treatment, storage capacity, disposal services, necessary technical services and materials, and prospective technologies for each corrective action alternative.

\section{Cost}

Costs for each alternative are estimated for comparison purposes only. The cost estimate for each corrective action alternative includes both capital and operation and maintenance costs, as applicable. The following is a brief description of each component:

- Capital Costs. These costs include both direct and indirect costs. Direct costs may consist of materials, labor, mobilization, demobilization, site preparation, construction materials, equipment purchase and rental, sampling and analysis, waste disposal, and health and safety measures. Indirect costs include such items as engineering design, permits and/or fees, start-up costs, and any contingency allowances.

- Operation and Maintenance. These costs include labor, training, sampling and analysis, maintenance materials, utilities, and health and safety measures.

Cost estimates for the corrective action alternatives are provided in Appendix C.

\subsection{Development of Corrective Action Alternatives}

This section identifies and briefly describes the viable corrective action technologies and the corrective action alternatives considered for the affected media. Based on the review of existing data, 
future use, and current operations at the NTS, the following alternatives have been developed for consideration at CAU 140:

- Alternative 1 - No Further Action

- Alternative 2 - Clean Closure

- Alternative 3 - Closure in Place with Administrative Controls

Other technologies, such as bioremediation, were considered. However, these are not considered to be effective because of the limited volume and concentrations of contaminated material. These alternatives will not receive further consideration in this CADD. Table 3-1 summarizes the corrective action alternatives evaluated for each CAS.

Table 3-1

Corrective Action Alternatives for CAU 140 CASs

\begin{tabular}{|c|c|c|c|}
\hline Corrective Action Site & Alternative 1 & Alternative 2 & Alternative 3 \\
\hline \hline CAS 05-08-01 & $X$ & $X$ & $X$ \\
\hline CAS 05-08-02 & $X$ & & \\
\hline CAS 05-17-01 & $X$ & & \\
\hline CAS 05-19-01 & $X$ & & \\
\hline CAS 05-23-01 & $X$ & & $X$ \\
\hline CAS 05-35-01 & $X$ & & \\
\hline CAS 05-99-04 & $X$ & & \\
\hline CAS 22-99-04 & $X$ & & $X$ \\
\hline CAS 23-17-01 & $X$ & $X$ & \\
\hline
\end{tabular}

\subsubsection{Alternative 1 - No Further Action}

Under the No Further Action Alternative, no corrective action activities will be implemented. This alternative is a baseline case with which to compare and assess the other corrective action alternatives and their ability to meet the corrective action standards. This alternative does not meet the corrective action objectives for CASs 05-08-01, 05-23-01, and 23-17-01 because no actions are taken to prevent exposure to COCs.

\subsubsection{Alternative 2 - Clean Closure}

For contaminated surface and subsurface soil, Alternative 2 includes excavating and disposing of soil and debris with COCs. All impacted soil will be removed. A visual inspection will be conducted to 
ensure that debris and visible contamination have been removed; however, no contaminated debris is expected at the two CASs identified for this corrective action alternative. Verification soil samples also will be collected and analyzed for the presence of COCs. This will verify that the removal of COCs is complete.

If encountered, any material that is removed will be disposed of at an appropriate disposal facility. All excavated areas will be returned to surface conditions compatible with the intended future use of the site. Overburden soil, along with clean fill soil, will be used to backfill excavations after removal of the contaminated soil. Clean borrow soil will be removed from a nearby location for placement in voids, as necessary.

The following subsections provide appropriate CAS-specific information regarding Alternative 2, Clean Closure.

\subsubsection{Detonation Pits (CAS 05-08-01)}

Alternative 2 includes removal and proper disposal of the soil impacted by COCs around location A05. The metal edging above the impacted soil will be removed and properly disposed. Verification samples will be collected and analyzed for site-specific COCs to ensure adequate removal of contaminated soil. All void space(s) will be backfilled with clean soil. This CAS will be closed in accordance with NAC 445A (NAC, 2000b), as described in this section.

\subsubsection{Gravel Gertie (CAS 05-23-01)}

Alternative 2 for this CAS is not being considered for the following reasons: (1) the Gravel Gertie is listed for inclusion in the National Register of Historic Places (DRI, 1996), and (2) the large volume of waste that would be generated.

\subsubsection{Hazardous Waste Storage Area (CAS 23-17-01)}

Alternative 2 includes removal and proper disposal of the soil contaminated with COCs around location J20. Verification samples will be collected and analyzed for area-specific COCs to ensure removal of contaminated soil. All void spaces will be backfilled with clean soil, as necessary. This CAS will be closed in accordance with NAC 445A (NAC, 2000b), as described in this section. 


\subsubsection{Alternative 3 - Close in Place with Administrative Controls}

Alternative 3 will use administrative controls to prevent inadvertent contact with COCs. These controls would consist of use restrictions to minimize access and prevent unauthorized intrusive activities. The future use of the CAU would be restricted from any activity that would alter or modify the containment control unless appropriate concurrence was obtained from NDEP. The combination of these measures will effectively prevent inadvertent intrusive activities by humans and native wildlife and mobilization of COCs.

The following subsections provide appropriate CAS-specific information regarding Alternative 3, Close in Place with Administrative Controls.

\subsubsection{Detonation Pits (CAS 05-08-01)}

Alternative 3 includes administrative activities and costs associated with use restriction for the soil impacted at location A05. Additionally, installation of a perimeter fence with appropriate signage around the contaminated soil area.

The following evaluation of NAC 445A.227 (2) (a-k) (NAC, 2000b) supports the protection of groundwater from COCs at this CAS:

a. Depth to groundwater at the nearest well (UE-5c) is approximately $804 \mathrm{ft} \mathrm{bgs}$ (DOE/NV, 1996b). This well is located approximately 1.1 mi southeast of this CAS. Groundwater flow is generally to the southwest and may discharge at Ash Meadows (USGS, 1996).

b. The distance to the nearest active water-supply well (Water Well $5 \mathrm{~b}$ ) is approximately $3.6 \mathrm{mi}$ southeast of this CAS (DOE/NV, 1996b). Water Well $5 \mathrm{~b}$ is primarily used to provide potable water for Area 5. Groundwater flow is generally to the southwest (USGS, 1996).

c. Soil type at this site is generally poorly graded, moderately consolidated, alluvial silty sands with gravel and some cobble-sized volcanic detritus.

d. Average annual precipitation for valleys in the South-Central Great Basin ranges from 3 to 6 inches (in.) (Winograd and Thordarson, 1975). Annual evaporation is roughly 5 to 25 times the annual precipitation (Winograd and Thordarson, 1975). The high potential evaporation and low precipitation rates create a negative water balance for the area; therefore, no driving force associated with precipitation is available to mobilize COCs vertically. 
e. Lead and the radionuclides Th-234, U-235, and U-238 are present in the soil around location A05. Downward migration of the COCs is slowed by the following parameters:

- Volume of release - it is assumed that small volumes of these COCs were released over a short duration.

- $\quad$ Soil saturation - the soil is dry, especially near the surface and shallow subsurface where the COCs are concentrated.

- $\quad$ Soil particle adsorption/desorption - These COCs tend to adsorb to the soil particles with little desorption, as suggested by the limited vertical migration of COCs.

f. The lateral extent of contamination is defined by analytical data showing the lack of COCs found in nearby sample locations, thereby demonstrating minimal lateral mobility (i.e., $<5 \mathrm{ft}$ ). Contaminant concentrations below the upper sampling horizons were significantly lower, demonstrating minimal vertical migration. The vertical extent of contamination is confined between the surface and $4 \mathrm{ft}$ bgs.

g. Presently, CAS 05-08-01 is located on a government-controlled facility. The NTS is a restricted area that is guarded on a 24-hour, 365-day per year basis; unauthorized personnel are not admitted to the facility. Corrective Action Site 05-08-01 is contained within a restricted use zone classified as a "NTS Reserved Land-Use Zone" (i.e., nonresidential) (DOE/NV, 1998).

h. Preferred routes of vertical and lateral migration are nonexistent since the sources have been eliminated and driving forces are not viable.

i. See Section 2.3.1 for site-specific considerations.

j. The potential for a hazard related to fire, vapor, or explosion is nonexistent for the COCs at the site.

k. No other site-specific factors are known at this site.

Based on this evaluation, impacts to groundwater are not expected. Therefore, groundwater monitoring is not proposed for this site and is not considered an element of the alternatives.

\subsubsection{Gravel Gertie (CAS 05-23-01)}

Alternative 3 includes administrative activities and costs associated with use restriction for the Gravel Gertie structure. Additionally, this alternative includes installation of a perimeter fence with appropriate signage around the Gravel Gertie. 
The following evaluation of NAC 445A.227 (2) (a-k) (NAC, 2000b) supports the protection of groundwater from COCs at this CAS:

a. Depth to groundwater at the nearest well (Water Well 5c) is approximately $601 \mathrm{ft}$ bgs (DOE/NV, 1996b). This well is located approximately $1.9 \mathrm{mi}$ to the northeast of this CAS. Groundwater flow is generally to the southwest and may discharge at Ash Meadows (USGS, 1996).

b. The distance to the nearest active water-supply well (Water Well 5c) is approximately $1.9 \mathrm{mi}$ to the northeast of this CAS (DOE/NV, 1996b). Water Well 5c is primarily used to provide potable water for Area 5. Groundwater flow is generally to the southwest (USGS, 1996).

c. Soil type at this site is generally poorly graded, moderately consolidated, alluvial silty sands with gravel, and some cobble-sized volcanic detritus.

d. Average annual precipitation for valleys in the South-Central Great Basin ranges from 3 to 6 in. (Winograd and Thordarson, 1975). Annual evaporation is roughly 5 to 25 times the annual precipitation (Winograd and Thordarson, 1975). The high evaporation and low precipitation rates create a negative water balance for the area; therefore, no driving force associated with precipitation is available to mobilize COCs vertically.

e. Uranium is assumed to be present inside the Gravel Gertie. Downward migration of COCs is slowed by the following parameters:

- Volume of release - it is assumed that small volumes of COCs were released over a short duration.

- $\quad$ Soil saturation - the soil tends to be very dry, especially near the surface and shallow subsurface where the COCs are concentrated.

- $\quad$ Soil particle adsorption/desorption - This COC tend to adsorb to the soil particles with little desorption.

f. Uranium is assumed to be contained within the Gravel Gertie structure. The lateral extent of the soil contamination is defined by analytical data indicating the lack of contamination found in the nearby sampling locations, thereby demonstrating minimal lateral mobility. Contaminant concentrations below the Gravel Gertie were not obtained; however, minimal vertical migration is thought to exist at this structure. The vertical extent of contamination has not been defined; however, is not believed to extend beneath the ground surface.

g. Presently, CAS 05-23-01 is located on a government-controlled facility. The NTS is a restricted area that is guarded on a 24-hour, 365-day per year basis; unauthorized personnel are not admitted to the facility. Corrective Action Site 05-23-01 is contained within a 
restricted-use zone classified as a "NTS Reserved Land-Use Zone" (i.e., nonresidential) (DOE/NV, 1998).

h. Preferred routes of vertical and lateral migration are nonexistent since the sources have been eliminated and driving forces are not viable.

i. See Section 2.3.2 for site-specific considerations.

j. The potential for a hazard related to fire, vapor, or explosion is nonexistent for the COCs at the site.

k. No other site-specific factors are known at this site.

Based on this evaluation, impacts to groundwater are not expected. Therefore, groundwater monitoring is not proposed for this site and is not considered an element of the alternatives.

\subsubsection{Hazardous Waste Storage Area (CAS 23-17-01)}

Under Alternative 3, administrative controls will be implemented to restrict inadvertent contact with the landfill, and contaminated subsurface soil adjacent to the landfill at location J20. This includes installation of monuments with appropriate signage around the landfill and around location J20. The landfill cap ranged from 2.5- to 6-ft thick and has a gentle slope to the south.

The following evaluation of NAC 445A.227 (2) (a-k) (NAC, 2000b) supports the protection of groundwater from COCs at this CAS:

a. Depth to groundwater at the nearest well (sewage lagoon monitoring well) is approximately $1,165 \mathrm{ft}$ bgs (DOE/NV, 1997). This well is located approximately $0.4 \mathrm{mi}$ south of this CAS. Groundwater flow is generally to the southwest and may discharge at Ash Meadows (USGS, 1996).

b. The distance to the nearest active water-supply well (Army Well No. 1) is approximately $4.7 \mathrm{mi}$ southwest of the CAS (USGS, 1964). Army Well No. 1 is primarily used to provide potable water for Area 23. Groundwater flow is generally to the southwest (USGS, 1996).

c. Soil at this site is generally a light brown, silty gravel that is poorly sorted, and made up of alluvial, colluvial, and carbonate rocks.

d. Average annual precipitation for valleys in the South-Central Great Basin ranges from 3 to 6 in. (Winograd and Thordarson, 1975). Annual evaporation is roughly 5 to 25 times the annual precipitation (Winograd and Thordarson, 1975). The high evaporation and low 
precipitation rates create a negative water balance for the area; therefore, no driving force associated with precipitation is available to mobilize COCs vertically.

e. TPH (DRO) was identified in the subsurface soil surrounding location J20. Downward migration of COCs is slowed by the following parameters:

- Volume of release - it is assumed that small volumes of COCs were released over a short duration.

- $\quad$ Soil saturation - the soil is dry, especially near the surface where the COCs are concentrated.

- Soil particle adsorption/desorption - petroleum hydrocarbons tend to adsorb to the soil particles with little desorption, as suggested by the limited vertical migration of COCs.

f. The lateral extent of the soil contamination is defined by analytical data indicating the lack of contamination found in the step-out locations, thereby demonstrating minimal lateral mobility. Contaminant concentrations below the sampling horizons where COCs were encountered were significantly lower, demonstrating minimal vertical migration. The vertical extent of contamination is confined from $5 \mathrm{ft}$ to $14 \mathrm{ft}$ bgs.

g. Presently, CAS 23-17-01 is located on a government-controlled facility. The NTS is a restricted area that is guarded on a 24-hour, 365-day per year basis; unauthorized personnel are not admitted to the facility. Corrective Action Site 23-17-01 is contained within a restricted-use zone classified as a "NTS Reserved Land-Use Zone" (i.e., nonresidential) (DOE/NV, 1998).

h. Preferred routes of vertical and lateral migration are nonexistent since the sources have been eliminated and driving forces are not viable.

i. See Section 2.3.3 for site-specific considerations.

j. The potential for a hazard related to fire, vapor, or explosion is nonexistent for the COCs at the site.

k. No other site-specific factors are known at this site.

Based on this evaluation, impacts to groundwater are not expected. Therefore, groundwater monitoring is not proposed for this site and is not considered an element of the alternatives.

\subsection{Evaluation and Comparison of Alternatives}

The general corrective action standards and remedy selection decision factors described in Section 3.2 were used to conduct detailed and comparative analyses of each corrective action 
alternative. The advantages and disadvantages of each alternative were assessed to select preferred alternatives for CAU 140. Table 3-2 and Table 3-3 present the detailed and comparative evaluation of closure alternatives for each CAS requiring corrective action. 
Table 3-2

Detailed Evaluation of Alternatives for Corrective Action Unit 140 (Page 1 of 2)

\begin{tabular}{|c|c|c|c|}
\hline Evaluation Criteria & $\begin{array}{l}\text { Alternative } 1 \\
\text { No Further Action }\end{array}$ & $\begin{array}{l}\text { Alternative } 2 \\
\text { Clean Closure }\end{array}$ & $\begin{array}{c}\text { Alternative } 3 \\
\text { Closure in Place with Administrative } \\
\text { Controls }\end{array}$ \\
\hline \multicolumn{4}{|c|}{ Closure Standards } \\
\hline $\begin{array}{l}\text { Protection of Human Health and the } \\
\text { Environment }\end{array}$ & \begin{tabular}{|l} 
Does not meet corrective \\
action objective of \\
preventing or mitigating \\
exposure to soil \\
containing COCs. \\
Does not prevent \\
potential spread of \\
COCs. \\
- Nevada Administrative \\
Code (NAC) 445.227 (2) \\
(a-k) analysis shows the \\
contaminants are not \\
expected to impact \\
groundwater. \\
No worker exposure \\
associated with \\
implementation.
\end{tabular} & $\begin{array}{l}\text { Meets corrective action objectives. } \\
\text { heavy equipment and potential contact with } \\
\text { impacted media during excavation, transportation, } \\
\text { and closure activities. } \\
\text { - Low risk to public due to remote location and } \\
\text { controlled access to the NTS. } \\
\text { NAC } 445.227 \text { (2) (a-k) analysis shows the } \\
\text { contaminants are not expected to impact } \\
\text { groundwater. } \\
\text { Moving contaminated media to an appropriate } \\
\text { disposal facility mitigates exposure to impacted } \\
\text { media after closure. }\end{array}$ & $\begin{array}{l}\text { Meets corrective action objectives. } \\
\text { - } \begin{array}{l}\text { Prevents inadvertent intrusion into the } \\
\text { contaminated media. }\end{array} \\
\text { equipment. } \\
\text { - Low risk to public because of remote location } \\
\text { and controlled access to the NTS. } \\
\text { NAC } 445.227 \text { (2) (a-k) analysis shows the } \\
\text { contaminants are not expected to impact } \\
\text { groundwater. }\end{array}$ \\
\hline $\begin{array}{l}\text { Compliance with Media Cleanup } \\
\text { Standards }\end{array}$ & $\begin{array}{l}\text { Does not comply with } \\
\text { media cleanup standards } \\
\text { because COCs remain. } \\
\text { NAC } 445.227(2)(a-k) \\
\text { analysis shows the } \\
\text { contaminants are not } \\
\text { expected to impact } \\
\text { groundwater. }\end{array}$ & $\begin{array}{l}\text { - Complies with media cleanup standards because } \\
\text { media containing COCs will be excavated and } \\
\text { disposed of at an appropriate facility. } \\
\text { - Removal of COCs will be verified with confirmation } \\
\text { sampling. } \\
\text { - NAC } 445.227 \text { (2) (a-k) analysis shows the } \\
\text { contaminants are not expected to impact } \\
\text { groundwater. }\end{array}$ & $\begin{array}{l}\text { Complies with media cleanup standards by } \\
\text { controlling exposure pathways. } \\
\text { NAC } 445.227 \text { (2) (a-k) analysis shows the } \\
\text { contaminants are not expected to impact } \\
\text { groundwater. }\end{array}$ \\
\hline Control the Source(s) of Release & $\begin{array}{l}\text { The sources of each CAS } \\
\text { have been discontinued. }\end{array}$ & - The sources of each CAS have been discontinued. & $\begin{array}{l}\text { The sources of each CAS have been } \\
\text { discontinued. }\end{array}$ \\
\hline $\begin{array}{l}\text { Comply with Applicable Federal, } \\
\text { State, and Local Standards for } \\
\text { Waste Management }\end{array}$ & No waste generated. & $\begin{array}{l}\text { All waste contaminated soil and disposable personal } \\
\text { protective equipment will be handled and disposed of } \\
\text { in accordance with applicable standards. }\end{array}$ & No waste generated. \\
\hline
\end{tabular}


Table 3-2

Detailed Evaluation of Alternatives for Corrective Action Unit 140 (Page 2 of 2)

\begin{tabular}{|c|c|c|c|}
\hline Evaluation Criteria & $\begin{array}{c}\text { Alternative } 1 \\
\text { No Further Action }\end{array}$ & $\begin{array}{l}\text { Alternative } 2 \\
\text { Clean Closure }\end{array}$ & $\begin{array}{c}\text { Alternative } 3 \\
\text { Closure in Place with Administrative } \\
\text { Controls }\end{array}$ \\
\hline \multicolumn{4}{|c|}{ Remedy Selection Decision Factors } \\
\hline $\begin{array}{l}\text { Short-Term Reliability and } \\
\text { Effectiveness }\end{array}$ & Not evaluated. & $\begin{array}{l}\text { Low risk to workers associated with heavy } \\
\text { equipment and potential contact with impacted } \\
\text { media during excavation, transportation, and } \\
\text { closure activities. } \\
\text { - Public protected during removal by remote location } \\
\text { and NTS site access controls. } \\
\text { Environmental impacts are not anticipated due to } \\
\text { implementation. Appropriate measures will be } \\
\text { taken at the site to protect desert tortoises. } \\
\text { - Implementation should not require an extended } \\
\text { period of time. }\end{array}$ & $\begin{array}{l}\text { Public protected by remote location and NTS } \\
\text { site-access controls. } \\
\text { Environmental impacts are not anticipated due } \\
\text { to implementation. Appropriate measures will } \\
\text { be taken at the site to protect desert tortoises. } \\
\text { Implementation should not require an extended } \\
\text { period of time. }\end{array}$ \\
\hline $\begin{array}{l}\text { Reduction of Toxicity, Mobility, } \\
\text { and/or Volume }\end{array}$ & Not evaluated. & $\begin{array}{l}\text { Clean closure would effectively eliminate } \\
\text { associated toxicity, mobility, and volume of wastes } \\
\text { at each CAS. } \\
\text { - Proper disposal of the waste will result in an } \\
\text { ultimate reduction of mobility. }\end{array}$ & $\begin{array}{l}\text { The mobility of the remaining surface } \\
\text { contamination is reduced by administrative } \\
\text { controls. } \\
\text { The mobility of the remaining subsurface soil } \\
\text { contamination is significantly reduced by } \\
\text { administrative controls and lack of viable driving } \\
\text { forces. } \\
\text { Toxicity and volume of the soil contamination } \\
\text { are effectively unchanged. }\end{array}$ \\
\hline $\begin{array}{l}\text { Long-Term Reliability and } \\
\text { Effectiveness }\end{array}$ & Not evaluated. & $\begin{array}{l}\text { - All risk will be eliminated on site upon completion. } \\
\text { - } \text { Mo maintenance required. } \\
\text { disposal facility addresses the persistent } \\
\text { adsorption of contaminants. }\end{array}$ & $\begin{array}{l}\text { Controls inadvertent intrusion to remaining } \\
\text { contaminated media. } \\
\text { - Administrative controls must be maintained. }\end{array}$ \\
\hline Feasibility & Not evaluated. & $\begin{array}{l}\text { Removal of contaminated media requires controls } \\
\text { to protect workers. } \\
\text { Options for disposal of contaminated media is } \\
\text { limited and requires coordination with multiple } \\
\text { entities. }\end{array}$ & $\begin{array}{l}\text { Easily implemented. } \\
\text { ensure compliance with administrative controls } \\
\text { to prevent intrusion into contaminated zones. }\end{array}$ \\
\hline Cost & $\begin{array}{l}\text { CAS 05-08-01: } \$ 0 \\
\text { CAS 05-23-01: } \$ 0 \\
\text { CAS 23-17-01: } \$ 0\end{array}$ & $\begin{array}{l}\text { CAS 05-08-01: } \$ 40,382 \\
\text { CAS 23-17-01: } \$ 58,614 \\
\text { Post Closure Monitoring all CASs: } \$ 117,132\end{array}$ & $\begin{array}{l}\text { CAS 05-08-01: } \$ 19,249 \\
\text { CAS 05-23-01: } \$ 25,164 \\
\text { CAS 23-17-01: } \$ 25,878 \\
\text { Post Closure Monitoring all CASs: } \$ 280,288 \\
\end{array}$ \\
\hline
\end{tabular}


Table 3-3

\section{Comparative Evaluation of Alternatives for \\ Corrective Action Unit 140}

\begin{tabular}{|c|c|c|c|}
\hline Evaluation Criteria & \multicolumn{3}{|c|}{ Comparative Evaluation } \\
\hline \multicolumn{4}{|l|}{ Closure Standards } \\
\hline $\begin{array}{l}\text { Protection of Human Health and the } \\
\text { Environment }\end{array}$ & \multicolumn{3}{|c|}{$\begin{array}{l}\text { Alternatives } 2 \text { and } 3 \text { meet corrective action objectives; Alternative } 1 \text { does not. No worker exposure to risks are associated with } \\
\text { Alternative } 1 \text {. Low risks are associated with Alternative } 3 \text { and slightly higher risks with Alternative 2. NAC 445A.227 (2) (a-k) analysis } \\
\text { shows the contaminants are not threatening groundwater. }\end{array}$} \\
\hline Compliance with Media Cleanup Standards & \multicolumn{3}{|c|}{$\begin{array}{l}\text { Alternative } 1 \text { does not comply with media cleanup standards. Alternative } 2 \text { meets media cleanup standards by removing } \\
\text { COC-impacted soil or unrestricted release criteria and eliminating exposure pathways at the site. Alternative } 3 \text { controls access to } \\
\text { contaminants, effectively eliminating exposure pathways. }\end{array}$} \\
\hline Control the Source(s) of Release & \multicolumn{3}{|c|}{ The sources at each CAS have been discontinued. } \\
\hline $\begin{array}{l}\text { Comply with Applicable Federal, State, and } \\
\text { Local Standards for Waste Management }\end{array}$ & \multicolumn{3}{|c|}{$\begin{array}{l}\text { Alternatives } 1 \text { and } 3 \text { do not generate waste. Alternative } 2 \text { will generate waste that will be handled in accordance with applicable } \\
\text { standards. }\end{array}$} \\
\hline \multicolumn{4}{|l|}{ Remedy Selection Decision Factors } \\
\hline Short-Term Reliability and Effectiveness & \multicolumn{3}{|c|}{ Low risks are associated with Alternative 3 and slightly higher risks with Alternative 2 . } \\
\hline $\begin{array}{l}\text { Reduction of Toxicity, Mobility, and/or } \\
\text { Volume }\end{array}$ & \multicolumn{3}{|c|}{$\begin{array}{l}\text { Alternative } 2 \text { results in an immediate reduction of all three characteristics at each CAS. Alternative } 3 \text { results in a reduction of mobility, } \\
\text { but does not reduce toxicity or volume for any of the CASs. }\end{array}$} \\
\hline Long-Term Reliability and Effectiveness & \multicolumn{3}{|c|}{$\begin{array}{l}\text { Residual risk at each CAS is low for Alternative } 3 \text { and nonexistent for Alternative } 2 \text {. Alternative } 3 \text { requires administrative measures to } \\
\text { control intrusive activities. }\end{array}$} \\
\hline Feasibility & \multicolumn{3}{|c|}{ Alternatives 2 and 3 are feasible; however, Alternative 2 will be more resource intensive. } \\
\hline Cost & $\begin{array}{l}\text { CAS 05-08-01: } \$ 0 \\
\text { CAS 05-23-01: } \$ 0 \\
\text { CAS 23-17-01: } \$ 0\end{array}$ & $\begin{array}{l}\text { CAS 05-08-01: } \$ 40,382 \\
\text { CAS 23-17-01: } \$ 58,614 \\
\text { Post Closure Monitoring all CASs: } \$ 117,132\end{array}$ & $\begin{array}{l}\text { CAS 05-08-01: } \$ 19,249 \\
\text { CAS 05-23-01: } \$ 25,164 \\
\text { CAS 23-17-01: } \$ 25,878 \\
\text { Post Closure Monitoring all CASs } 280,288\end{array}$ \\
\hline
\end{tabular}




\subsection{Recommended Alternatives}

The preferred corrective action alternatives were evaluated on their technical merits, focusing on performance, reliability, feasibility, and safety. The selected alternatives were judged to meet all requirements for the technical components evaluated. The selected alternatives meet all applicable state and federal regulations for closure of the sites and will minimize potential future exposure pathways to the contaminated media at CAU 140.

Alternative 1, No Further Action, is the preferred corrective action for CASs 05-08-02, 05-17-01, 05-19-01, 05-35-01, 05-99-04, and 22-99-04.

Alternative 2, Clean Closure is the preferred corrective action for the following CAS:

- CAS 05-08-01 - Remove metal edging and COC-impacted soil around location A05.

Alternative 3, Closure-in-Place, is the preferred corrective action for the following CASs:

- CAS 05-23-01 - Gravel Gertie

- CAS 23-17-01 - Hazardous Waste Storage Area

The preferred corrective action alternatives were evaluated on technical merit focusing on performance, reliability, feasibility, and safety. The alternatives were judged to meet all requirements for the technical components evaluated. The alternatives meet all applicable state and federal regulations for closure of the site and will eliminate potential future exposure pathways to the contaminated soils at CAU 140. Implementation of corrective actions may potentially present risks to site workers; therefore, appropriate health and safety procedures will be developed and implemented.

In addition to the closure activities outlined above, the surface debris at CASs 05-08-01, 05-08-02, 05-17-01, 05-19-01, and 05-99-04 will be removed and disposed as a best management practice during closure activities. 


\subsection{References}

CFR, see Code of Federal Regulations.

Code of Federal Regulations. 2002a. Title 40 CFR Parts 260 - 282, "RCRA Regulations." Washington, DC: U.S. Government Printing Office.

Code of Federal Regulations. 2002b. Title 40 CFR 761.61, "PCB Remediation Waste."

Washington, DC: U.S. Government Printing Office.

DOE/NV, see U.S. Department of Energy, Nevada Operations Office.

DRI, see Desert Research Institute.

Desert Research Institute. 1996. Nevada Test Site Historical Structures Survey, Technical Report

No. 87, DOE/NV/95NV11508-05, UC-702. Las Vegas, NV: Quaternary Sciences Center.

EPA, see U.S. Environmental Protection Agency.

FFACO, see Federal Facility Agreement and Consent Order.

Federal Facility Agreement and Consent Order. 1996 (as amended). Agreed to by the State of Nevada, the U.S. Department of Energy, and the U.S. Department of Defense.

NAC, see Nevada Administrative Code.

NDEP, see Nevada Division of Environmental Protection.

NNSA/NV, see U.S. Department of Energy, National Nuclear Security Administration Nevada Operations Office.

NRS, see Nevada Revised Statutes.

Nevada Administrative Code. 2000a. NAC 444, "Sanitation.” Carson City, NV.

Nevada Administrative Code. 2000b. NAC 445A, "Water Controls.” Carson City, NV.

Nevada Administrative Code. 2000c. NAC 445A.2272, "Contamination of Soil: Establishment of Action Levels." Carson City, NV.

Nevada Administrative Code. 2000d. NAC 459, "Hazardous Materials.” Carson City, NV. 
Nevada Revised Statutes. 1998. NRS 459.400-459.600, “Disposal of Hazardous Waste.” Carson City, NV.

Sandia Corporation. 1964. Measurements from Gravel Gertie Tests, July, SC-R-64-127. Albuquerque, NM.

USGS, see U.S. Geological Survey.

U.S. Department of Energy, National Nuclear Security Administration Nevada Operations Office. 2002a. Corrective Action Investigation Plan for Corrective Action Unit 140: Waste Dumps, Burn Pits, and Storage Area, Nevada Test Site, Nevada, DOE/NV--826. Las Vegas, NV.

U.S. Department of Energy, National Nuclear Security Administration Nevada Operations Office. 2002b. Industrial Sites Quality Assurance Project Plan, Nevada Test Site, Nevada, Rev. 3, DOE/NV-372. Las Vegas, NV.

U.S. Department of Energy, Nevada Operations Office. 1994. Project Management Plan, Rev. 0. Las Vegas, NV.

U.S. Department of Energy, Nevada Operations Office. 1996a. Final Environmental Impact Statement for the Nevada Test Site and Off-Site Locations in the State of Nevada, DOE/EIS 0243. Las Vegas, NV.

U.S. Department of Energy, Nevada Operations Office. 1996b. Nevada Test Site Water-Supply Wells, DOE/NV/10845-56, Publication No. 45138. Prepared by E.D. Gillespie, D. Donithan, and P. Seaber. Las Vegas, NV: Desert Research Institute.

U.S. Department of Energy, Nevada Operations Office. 1997. Annual Report Post-Closure Monitoring and Inspection for the Mercury Landfill Hazardous Waste Trenches for the Period October 1995-October 1996, DOE/NV-11718, UC-712, January. Las Vegas, NV.

U.S. Department of Energy, Nevada Operations Office. 1998. Nevada Test Site Resource Management Plan, DOE/NV-518. Las Vegas, NV.

U.S. Environmental Protection Agency. 1991. Guidance on RCRA Corrective Action Decision Documents, EPA/540/G-91/011. Washington, DC: Office of Research and Development.

U.S. Environmental Protection Agency. 1994. Final RCRA Corrective Action Plan, EPA/520-R-94-004. Washington, DC: Office of Solid Waste and Emergency Response.

U.S. Environmental Protection Agency. 2000. Region IX Preliminary Remediation Goals (PRGs). As accessed at www.epa.gov/region09/waste/sfund/prg/index.htm on 8 January 2001. Prepared by S.J. Smucker. San Francisco, CA. 
U.S. Geological Survey. 1964. Summary of Hydraulic Data, Quality of Water, and Lithologic Log for Army Well 1, Mercury Valley, Nye County, Nevada, Technical Letter NTS-71, 15 January. Prepared by G.L. Meyer, and R.E. Smith. Denver, CO.

U.S. Geological Survey. 1996. Summary of Hydrogeological Controls on Ground-Water Flow at the Nevada Test Site, Nye County, Nevada, USGS-WRIR-96-4109. Prepared by R.L. Laczniak, J.C. Cole, D.A. Sawyer, and D.A. Trudeau. Carson City, NV.

Winograd, I.J., and W. Thordarson. 1975. Hydrologic and Hydrochemical Framework

South-Central Great Basin, Nevada-California, with Special Reference to the Nevada Test Site, USGS Professional Paper 712C. Washington, DC: U.S. Government Printing Office. 
Appendix A

Corrective Action Investigation Report for Corrective Action Unit 140 


\section{A.1.0 Introduction}

This appendix details corrective action investigation (CAI) activities and analytical results for CAU 140. This CAU is located in Areas 5, 22, and 23 of the NTS and is comprised of the following CASs (see Figure 1-1 of main document):

- 05-08-01, Detonation Pits

- 05-08-02, Debris Pits

- 05-17-01, Hazardous Waste Accumulation Site (Buried)

- 05-19-01, Waste Disposal Site

- 05-23-01, Gravel Gertie

- 05-35-01, Burn Pit

- 05-99-04, Burn Pit

- 22-99-04, Radioactive Waste Dump

- 23-17-01, Hazardous Waste Storage Area

The CASs in CAU 140 were used for testing, material storage, waste storage, and waste disposal. The CAU is comprised of two detonation pit/sites, one debris pit, four hazardous/radioactive waste storage/disposal areas, and two burn pits. Investigation of CAU 140 was performed because process knowledge indicated that waste may be present without appropriate controls and hazardous and/or radioactive constituents may be present or migrating.

Additional information regarding the history of each site, planning, and the scope of the investigation is presented in the CAIP (NNSA/NV, 2002a). The CAI was conducted in accordance with the CAIP for CAU 140 as developed under the FFACO (1996).

\section{A.1.1 Objectives}

The primary objective of the investigation was to provide sufficient information and data to develop appropriate corrective action alternatives for each CAS in CAU 140. This objective was achieved by confirming the absence of or defining the nature and extent of COCs (i.e., COPCs at concentrations above PALs) and other information and data (e.g., confirming no buried debris, topographic survey, and geotechnical data). 
The selection of soil sample locations was based on site conditions and the strategy developed during the DQO process as outlined in the CAIP. Changes to the sampling strategy were based on site-specific conditions and are documented in project records.

\section{A.1.2 Report Content}

This appendix contains information and data to support the selection of a preferred corrective action alternative in the CADD. The contents of this report are as follows:

- Section A.1.0 describes the investigation background, objectives, and report contents.

- $\quad$ Section A.2.0 provides an investigation overview.

- Section A.3.0 through Section A.11.0 provides CAS-specific information regarding field activities, sampling methods, and laboratory analytical results from investigation samples.

- Section A.12.0 summarizes waste management activities.

- Section A.13.0 discusses quality assurance (QA) and QC procedures followed during the CAI and results of the supporting QA/QC activities.

- Section A.14.0 is a summary of investigation results.

- Section A.15.0 lists cited references.

The complete field documentation and laboratory data, including field activity daily logs (FADLs), sample collection logs, analysis request/chain-of-custody forms, soil sample descriptions, laboratory certificates of analyses, analytical results, and surveillance results are retained in project files as hard copy files or in electronic format. 


\section{A.2.0 Investigation Overview}

The CAI was accomplished by collecting soil samples from surface locations, backhoe excavations, auger holes, and rotosonic boreholes. The field investigation was conducted from November 13 through December 11, 2002. Additional sampling to delineate the extent of COCs was conducted on February 4 and March 18 and 19, 2003.

The CAI was managed in accordance with the requirements and approach set forth in the CAIP. Field activities were performed following the approved site-specific health and safety plan (SSHASP) (IT, 2002), which is consistent with the DOE Integrated Safety Management System. Samples were collected and documented following approved protocols and procedures specified in the CAIP. Quality control samples (e.g., field blanks, equipment rinsate blanks, trip blanks, and field duplicates) were collected as required by the Industrial Sites QAPP (NNSA/NV, 2002b) and approved procedures. During the CAI, waste minimization practices were followed according to approved procedures, including segregation of waste by waste stream.

Weather conditions at the site varied including rainy, sunny (low to moderate temperatures), intermittent cloudiness, and light to strong winds. High winds occasionally delayed site operations; otherwise, weather conditions were generally favorable.

The CASs were characterized through the laboratory analysis of surface and subsurface soil samples. Samples were collected by rotosonic drilling, backhoe, and hand tools. Investigation intervals and soil samples were field screened for VOCs and alpha and beta/gamma radiation. Selected CASs were also field screened for explosives and TPH. The results were compared against FSLs to guide the investigation. Select samples were shipped to an off-site laboratory to be analyzed for selected chemical and radiological parameters identified during the DQO process.

Corrective Action Unit 140 sampling locations were accessible and sampling activities at planned locations were not restricted by buildings, storage areas, active operations, or aboveground and underground utilities. Sampling step-out locations were accessible and remained within anticipated spatial boundaries that were identified in Appendix A of the CAIP. 
Sections A.2.1 through A.2.8 provide the investigation methodology, site geology and hydrology, and laboratory information. The CAS-specific investigation details are provided in Section A.3.0 through Section A.11.0.

\section{A.2.1 Preliminary Conceptual Model}

The site-specific conditions were consistent with the preliminary CMSs developed during the DQO process and provided in the CAIP. Therefore, no revisions to the CSMs for these CASs were needed.

\section{A.2.2 Sample Locations}

Locations selected for sampling were based on interpretation of engineering drawings, aerial photographs, interviews with former and current site employees, and site conditions as provided in the CAIP. The planned, biased sample locations are shown in the CAIP. Actual sample locations are shown in figures in each CAS-specific section of this appendix. Some locations were modified slightly from planned positions due to field conditions and observations. All sample locations were staked in the field, labeled appropriately, and surveyed with a GPS instrument. The actual locations have been plotted on the figures based on the GPS coordinates. In addition to the sampling locations, the figures also show points of interest and cultural features that aid in the understanding of the CAS, which also have associated GPS coordinates. The GPS coordinates are located in Appendix E and the figures are in the CAS-specific sections of this appendix.

\section{A.2.2.1 Housekeeping Removal of Debris}

Removal and disposition of surface materials was performed by Bechtel Nevada (BN) at CASs 5-19-01 (concrete and rebar) and 5-08-02 (tire and oil filters). At CAS 5-08-01, an unexploded ordnance (UXO) surface sweep was performed to locate and remove any UXO found; however, none were found. 


\section{A.2.3 Investigation Activities}

The investigation activities performed at CAU 140 were based on the field investigation activities discussed in the CAIP (NNSA/NV, 2002a). The technical approach consisted of the following activities:

- Excavations

- Rotosonic drilling

- Field screening

- Surface (hand) and subsurface soil sampling

- Characterization of waste streams

- Locating sample points and cultural features using GPS equipment

This investigation strategy allowed the nature and extent of COCs associated with each CAS to be established. The following sections describe the specific investigation activities that took place at CAU 140.

\section{A.2.3.1 Excavations}

Backhoe excavations were used to access soil sample horizons at CASs 5-19-01 and 23-17-01. Additionally, excavations served to explore areas of suspected buried debris tentatively identified from the geophysical surveys at CASs 5-08-01, 5-17-01, and 5-19-01. No buried debris was found at these three CASs; therefore, soil sampling of subsurface debris was not performed.

Excavations around the perimeter of the landfill were also used at CAS 23-17-01 to better define the landfill dimensions, the thickness of the landfill cover, and to establish sampling locations. A geophysical survey was used to bias the excavation locations. Backhoe trenches were generally oriented perpendicular to the trace of the disposal feature boundary, and were started outside of the suspected boundary and worked inward until debris was observed. As soon as debris was observed, the location was noted and staked and the trench backfilled. This approach minimized the penetration of the landfill material. Information from the trenching was used to locate the soil sampling locations around the perimeter of the landfill. Samples were collected using a rotosonic drill rig.

Spoils from the excavation were temporarily staged next to excavations. Once the excavation was completed, the soil was returned as near to its original location as practical. 


\section{Topographic Survey and Geotechnical Analysis at CAS 23-17-01}

After the lateral extent of the disposal features had been confirmed, BN conducted topographic surveys to determine the slope of the cover and surrounding land surface.

Geotechnical analysis was conducted on selected samples and the data used to determine the hydraulic and physical characteristics of disposal feature covers (primarily permeability) and to compare to subsurface permeability.

\section{A.2.3.2 Backhoe and Hand Sampling Methodology}

During backhoe sampling at CASs 5-19-01 and 23-17-01, soil was initially screened in the backhoe bucket for health and safety parameters prior to collection of laboratory samples. Additional screening was conducted during sample collection to guide the investigation. Labeled sample containers were filled according to the following sequence. The total VOCs and gasoline-range organics (GRO) sample containers were filled with soil directly from the backhoe bucket, followed by collection of soil for VOC field screening using headspace analysis. Additional soil was transferred into a stainless-steel bowl, homogenized, and screened for alpha and beta/gamma radiation. Once the screening was completed, the remaining sample containers were filled with the homogenized soil in the stainless-steel bowl.

Surface and shallow subsurface (1 to $4 \mathrm{ft}$ bgs) soil samples were collected by hand at all CASs except CAS 23-17-01, where a backhoe was used. Shallow subsurface soil samples were accessed with either a hand or power auger and collected by hand once the sample horizon was reached. The total VOCs and GRO sample containers were filled with soil directly from the locations, followed by collection of soil for VOC field screening using headspace analysis. Additional soil was transferred into a stainless-steel bowl, homogenized, and screened for alpha and beta/gamma radiation prior to filling the remaining sample containers. Excess soil was returned to the sampling locations. Custody seals were applied to the sample containers once collection was complete.

\section{A.2.3.3 Rotosonic Sampling at CAS 23-17-01}

Samples were collected at CAS 23-17-01 using a rotosonic drill rig. This rig used a hollow-core barrel fitted with a standard carbide button bit. The core barrel was advanced via sonic vibrating 
pull-down and rotation, and when the barrel was full (or blocked, as was often the case), it was brought to the surface and the contents extruded into long plastic bags.

To collect chemical/radiological samples, the driller was informed of the sample interval and drilled to that depth, as described above. A decontaminated core barrel was used to drill through the interval, the interval was extruded, the depth of the interval was marked on the bag, and the bag was delivered to the sample table. The total VOCs and GRO sample containers were filled first, followed by collection of soil for VOC field screening using headspace analysis. Additional soil was transferred into a stainless-steel bowl, homogenized, and screened for alpha and beta/gamma radiation prior to filling the remaining sample containers. Excess soil was returned to the sampling locations and custody seals were applied to the samples.

Geotechnical samples were collected in the same fashion from the landfill cap and the native soil beneath the landfill, except a split spoon loaded with decontaminated brass sleeves was used to preserve in situ conditions. The sleeves (which served as the sample container) were immediately capped, taped, labeled, and stored until shipment to the geotechnical laboratory.

\section{A.2.4 Field-Screening Methodology}

Field-screening activities for VOC and alpha and beta/gamma radiation were performed in accordance with the CAIP. The FSL for VOC headspace was established at 20 parts per million (ppm) or 2.5 times background, whichever was greater. The site-specific FSLs for alpha and beta/gamma radiation were defined as the mean background activity level plus two times the standard deviation of readings from 20 background locations. The radiation FSLs are instrument-specific and were established for each instrument prior to use. Field screening was conducted using a photoionization detector for VOCs and an NE Technologies Electra with a DP6 dual-alpha and beta/gamma radiation scintillation probe.

\section{A.2.5 Geology and Hydrology}

\section{$\underline{\text { Area } 5}$}

Seven of the CAU 140 CASs are located in Area 5 of NTS on an alluvial fan in the Frenchman Flat basin. Most of Area 5 is in the vicinity of Frenchman Lake, which is a playa occupying a topographic 
depression at the center of the Frenchman Flat basin. The complex geology of Frenchman Flat produced a varied stratigraphy. In Frenchman Flat, the alluvium ranges from a thin covering along the valley edges to perhaps as much as 3,000 ft thick in the north central portion of Frenchman Flat (DOE/NV, 1999). The sands, gravels, silts, and clays form a level flood plain.

Regional native surface soil consists of poorly graded, moderately consolidated, alluvial silty sands with gravel, and some cobble-sized volcanic and sedimentary detritus. The percentage of organic matter in the surface soil is low and generally decreases with depth. No caliche was encountered during excavation sampling at any of the CASs. A general field description for each sample was recorded on sample collection logs.

Dry washes provide channels that concentrate surface runoff; however, there is no perennial streamflow in the region. Surface topography at all of the CASs ranged from nearly flat to sites where distribution planes slope gently in the down-flow direction.

Most groundwater flowing beneath the Frenchman Flat basin passes through the lower carbonate-rock aquifer. This aquifer is the only subsurface pathway by which groundwater leaves the basin. As generalized from contours constructed from water-level measurements made in wells that penetrate into the aquifer, groundwater flows southwest from Frenchman Flat toward the major downgradient areas (primarily Ash Meadows, but possibly Alkali Flat or Death Valley) (USGS, 1996).

Hydrologic conditions beneath the CASs are less important to site characterization because individual discharge points are generally at surface grade, and alluvium is likely to reach depths of greater than 3,000 ft bgs (NNSA/NV, 2002a). Due to depth to groundwater and climatic conditions, groundwater at Area 5 is not expected to have been impacted by COPCs. The most shallow depth to groundwater in Area 5 is in Water Well 5C, which is approximately $601 \mathrm{ft} \mathrm{bgs} \mathrm{(DOE/NV,} \mathrm{1996b).} \mathrm{No} \mathrm{saturated}$ zones (e.g., perched water, contaminant saturation) were found anywhere in the subsurface adjacent to or below the CASs of CAU 140.

A more detailed description of the regional geology and hydrology including water levels of nearby wells is provided in the CAIP (NNSA/NV, 2002a). 


\section{$\underline{\text { Areas } 22 \text { and } 23}$}

Corrective Action Site 22-99-04 is located in Area 22 on an alluvial fan in the Mercury Valley. The Mercury Valley is underlain by moderately thick alluvium with an interbedded tuff unit. The alluvium consists of fine- to medium-grain carbonaceous and tuffaceous fragments eroded from surrounding mountain ranges with a matrix of calcareous silt. A unit of friable, tuffaceous bedrock is located within the alluvium from about 360 to $515 \mathrm{ft}$ bgs (USGS, 1962 and 1964).

Paleozoic carbonates and shale underlie the alluvial cover. The carbonate rocks are thought to belong to the Windfall Formation of Upper Cambrian age. The Windfall Formation is a highly fractured, brecciated, crystalline dolomite, and limestone. The Dunderberg Formation is a fissile, fossiliferous shale. Paleozoic carbonates below this are assigned as undifferentiated Paleozoic carbonate rocks (USGS, 1964).

Corrective Action Site 23-17-01 is located in Area 23 on an alluvial fan south of the Red Mountain Range. The alluvium in Area 23 is highly permeable as it consists of silty gravel that is poorly sorted, containing silt to boulder size rocks of quartzite, limestone, and dolomite, with some lenses of laminated calcium carbonate (Frazier, 1988).

Regional hydraulic gradients based on water-level data indicate that water moves toward Frenchman Flat, and then flows southwest through the regional carbonate-rock aquifer to the Ash Meadows subbasin (USGS, 1996). Depth to the Ash Meadow aquifer in the Mercury Valley is approximately $800 \mathrm{ft}$ bgs within the carbonate rocks. A deeper aquifer was also identified at an approximate depth of 1,360 ft bgs within the undifferentiated carbonate unit (USGS, 1964).

Hydrologic conditions beneath these two CASs are less important to site characterization because individual discharge points are generally at surface grade or shallow depths below $15 \mathrm{ft}$ bgs. Due to depth to groundwater and climatic conditions, groundwater at Areas 22 and 23 is not expected to have been impacted by COPCs. No saturated zones (e.g., perched water, contaminant saturation) were found during investigation activities adjacent to or below the discharge points. 


\section{A.2.6 Laboratory Analytical Information}

Chemical and radiological analyses were performed by Paragon Analytics, Inc., Fort Collins, Colorado. The analytical parameters and laboratory analytical methods used to analyze CAU 140 investigation samples are listed in Table A.2-1. Organic and inorganic analytical results are compared to the minimum reporting limits (MRLs) established in Table 3-3 in the CAIP (NNSA/NV, 2002a). The analytical results for gamma-emitting radionuclides, isotopic uranium, isotopic plutonium, strontium ( $\mathrm{Sr}$ )-90, and tritium are compared to the MRLs presented in Table 3-4 of the CAIP.

The validated analytical results of samples collected from the CAU 140 investigation have been compiled and evaluated to determine the presence and/or extent of COCs in Section A.3.0 through Section A.11.0. The complete laboratory data packages are available in the project central files.

The analytical parameters are CAS-specific and were selected through the application of site process knowledge according to the EPA's Guidance for the Data Quality Objectives Process (EPA, 1994a). Samples collected during Phase II (step-out) sampling were analyzed for only the parameters identified as COCs in the original samples.

Bioassessment samples were not collected because field-screening results and observations did not indicate the need. Geotechnical samples were collected at CAS 23-17-01 from the landfill cap material and the native soil beneath the landfill base. Geotechnical analyses were performed by D.B. Stevens and Associates, Albuquerque, New Mexico. The laboratory analytical methods used to analyze CAU 140 investigation samples are listed in Table 4-2 of the CAIP. The analytical results for the CAU 140 samples are provided in the CAS-specific section of this appendix.

\section{A.2.7 Comparison to Preliminary Action Levels}

Chemicals and radionuclides detected in samples at concentrations greater than PALs are identified as COCs. Based on an FFACO agreement, a corrective action must be considered for the CAS if COCs are present. The PALs for the CAU 140 investigation were determined during the DQO process. For chemical COPCs, PALs are EPA PRGs (EPA, 2000). The PAL for TPH is $100 \mathrm{mg} / \mathrm{kg}$ per the NAC 445A.2272 (NAC, 2000). Radionuclide concentrations measured in CAU 140 environmental samples were compared to isotope-specific PALs. A radionuclide PAL is defined as 
Table A.2-1

\section{Laboratory Analytical Parameters and Methods,} CAU 140 Investigation Samples

\begin{tabular}{|c|c|}
\hline Analytical Parameter & Analytical Method \\
\hline Total volatile organic compounds & SW-846 8260B ${ }^{a}$ \\
\hline Total semivolatile organic compounds & SW-846 8270C ${ }^{a}$ \\
\hline Total petroleum hydrocarbons - gasoline-range organics & SW-846 8015B (modified) ${ }^{a}$ \\
\hline Total petroleum hydrocarbons - diesel-range organics & SW-846 8015B (modified) ${ }^{a}$ \\
\hline Polychlorinated biphenyls & SW-846 $8082^{a}$ \\
\hline Total RCRA metals $^{\mathrm{b}}$ & \multirow{2}{*}{$\begin{array}{l}\text { Water - SW-846 6010B/7470A }{ }^{a, b} \\
\text { Soil - SW-846 6010B/7471A }\end{array}$} \\
\hline Total antimony, beryllium, nickel, and zinc & \\
\hline Ethylene Glycol & $8015 \mathrm{~B}^{\mathrm{a}}$ modified \\
\hline Total Pesticides & $8081 A^{a}$ \\
\hline Total Herbicides & $8151 \mathrm{~A}^{\mathrm{a}}$ \\
\hline Total Explosives & $8330^{\mathrm{a}}$ \\
\hline TCLP volatile organic compounds & SW-846 1311/8260B ${ }^{a, k}$ \\
\hline TCLP semivolatile organic compounds & SW-846 1311/8270C ${ }^{a, k}$ \\
\hline TCLP RCRA metals & SW-846 1311/6010B/7470A ${ }^{a, b, k}$ \\
\hline Gamma-emitting radionuclides & $\begin{array}{l}\text { Water - EPA } 901.1^{\mathrm{c}, \mathrm{d}} \\
\text { Soil - HASL-300 }\end{array}$ \\
\hline Isotopic uranium & $\begin{array}{l}\text { Water - ASTM D3972-02 } \\
\text { Soil ASTM C1000-00 }\end{array}$ \\
\hline Isotopic plutonium & $\begin{array}{l}\text { Water - ASTM D3865-02 } \\
\text { Soil - ASTMC1001-90 } \\
\text { c,i }\end{array}$ \\
\hline Strontium-90 & $\begin{array}{l}\text { Water -ASTM D5811-00 c,j } \\
\text { Soil - HASL-300 c, e }\end{array}$ \\
\hline Tritium & $\begin{array}{l}\text { Water - EPA 906.0 } \\
\text { Soil }^{k} \text { - PAI 754/704 }\end{array}$ \\
\hline
\end{tabular}

aU.S. Environmental Protection Agency (EPA), Test Methods for Evaluating Solid Waste, Physical/Chemical Methods, 3rd Edition, Parts 1-4, SW-846 (EPA, 1996)

${ }^{\mathrm{b}}$ Arsenic, barium, cadmium, lead, mercury, selenium, silver, and chromium

${ }^{\mathrm{C}}$ Or equivalent laboratory method

${ }^{\mathrm{d} P r e s c r i b e d}$ Methods for Measurement of Radioactivity in Drinking Water (EPA, 1980)

${ }^{\mathrm{e}}$ Environmental Measurements Laboratory Procedure Manual, HASL-300 (DOE, 1997)

fStandard Test Methods for Isotopic Uranium in Water by Radiochemistry (ASTM, 2002a)

${ }^{9}$ Standard Test Methods for Radiochemical Determination of Uranium in Soil by Alpha Spectroscopy (ASTM, 2000a)

${ }^{\mathrm{h}}$ Standard Test Methods for Plutonium in Water (ASTM, 2002b)

iStandard Test Methods for Radiochemical Determination of Plutonium in Soil by Alpha Spectroscopy (ASTM, 2000a)

'Standard Test Methods for Strontium-90 in Water (ASTM, 2000c)

${ }^{\mathrm{k}}$ Sludge sample

'Paragon Analytics, Inc. 
the maximum concentration in an environmental sample taken from an undisturbed background location in the vicinity of the NTS and throughout the state of Nevada, or the MDC if the isotope is not reported or reported below the MDC (NNSA/NV, 2002a). If a sample has a positive concentration for any radionuclide with a corresponding PAL, the sample result and its PAL concentration data are statistically compared. This comparison is used to determine if the activity of a given radionuclide is statistically different from the background or naturally occurring activity. The normalized difference test is used for this comparison. The test is defined as:

$$
\mathrm{t}=\frac{\mathrm{R}-\mathrm{PAL}}{\sqrt{\sigma_{\mathrm{R}^{2}}+\sigma_{\mathrm{PAL}}}}
$$

where:

$\mathrm{t} \quad=$ Normalized Difference Result

$\mathrm{R} \quad=$ Sample Radioanalytical Result

PAL = Preliminary Action Level

$\sigma_{\mathrm{R}}{ }^{2}=2$ Sigma Uncertainty in Radioanalytical Result

$\sigma_{\mathrm{PAL}}^{2}=2$ Sigma Uncertainty in PAL

The statistical assumptions inherent to the normalized difference test are as follows:

- The sample counts are drawn from normally distributed populations

- The counts for the sample and the PAL are centered on the sample result and the PAL

- The width parameter of the distribution is equal to two sigma

The "reasonable confidence" has been set to 95 percent for this comparison test. This means that for the sample radioanalytical result to statistically differ from the PAL (with a 95 percent confidence level), the normalized difference between the PAL and the sample radioanalytical result must be greater than or equal to 1.96. If the normalized difference is less than or equal to 1.96, the sample result and the PAL differ by less than or equal to a 5 percent level of significance. If the normalized difference is greater than 1.96 , there is a 95 percent confidence that the result is greater than the PAL. The result is ultimately considered to be greater than the PAL, if it is statistically different than the background-based PAL. 
Sample data that exceed MRLs are tabulated in the CAS-specific Sections A.3.0 through A.11.0. Results that are greater than PALs (a subset of those that exceed MRLs) are identified by bold text in the corresponding tables and discussed in Sections A.3.0 to A.11.0. Nondetected results and those below MRLs have been excluded to minimize the size of this document.

\section{A.2.7.1 Residual Surficial Plutonium Contamination at Frenchman Lake Area}

The dry lakebed of Frenchman Lake was the site of 14 atmospheric nuclear tests conducted between 1951 and 1962. The radionuclide inventory and distribution program (RIDP) was established in 1981 to make a comprehensive survey of the important man-made radionuclides of NTS origin in the NTS surface soil. The data used by the RIDP comes from three sources: aerial measurements of external exposure rate, in situ measurements of individual gamma-emitting radionuclides, and chemical and spectrometric analysis of soil samples. The data as presented in the Nevada Test Site Radionuclide Inventory and Distribution Program: Report \#5, Areas 5, 11, 12, 15, 17, 18, 19, 25, 26, and 30 (McArthur and Mead, 1989) was reviewed and the average plutonium (Pu)-239 surficial concentration ( 0 to 2.5 centimeters [cm] depth) was estimated at 6.48 picocuries per gram (pCi/g). The data ranged from 0.568 to $92.7 \mathrm{pCi} / \mathrm{g}$ of $\mathrm{Pu}-239$.

As a result of this atmospheric testing, CASs 05-08-01 and 05-19-01 have Pu-239 concentrations above PALs but less than the average concentration of $6.48 \mathrm{pCi} / \mathrm{g}$. Additionally, a background surface soil sample (140D001) was collected north and outside of the CAS 05-19-01 boundary and had a $\mathrm{Pu}-239$ concentration of $4.43 \mathrm{pCi} / \mathrm{g}$. 


\section{A.3.0 Detonation Pits (CAS 05-08-01)}

The Detonation Pits are located west of the Area 5 Radioactive Waste Management Site (RWMS), adjacent to a dirt road that leads north from Triple Point Bunker. The site includes two detonation pits, viewing area/blasting shield, three trenches, and scattered metal debris. The two detonation pits are at the north end of the CAS and measure approximately 4 by $15 \mathrm{ft}$. Each pit is surrounded by a thin 6-in. high metal edging. One of the pits is posted with radioactive material signs. The viewing area/blasting shield is approximately $300 \mathrm{ft}$ south of the detonation pits. The three trenches are south of the viewing area. The northern and southern trenches have a darker soil at the bottom of the trenches. Shrapnel debris is scattered around the detonation pits. Detonation wire and blasting caps are also found in the area. The site contains vegetation; however, there is no vegetation within the detonation pits (Figure A.3-1).

\section{A.3.1 Corrective Action Investigation}

Twelve soil and associated QC samples were collected from eight locations (D01 through D08) during investigation activities at this CAS and are listed in Table A.3-1. The planned sample locations are shown in Figure 4-1 in the CAIP (NNSA/NV, 2002a). The actual sample locations are shown in Figure A.3-1. The specific CAI activities conducted to meet CAIP requirements at CAS 5-08-01 are described in the following sections.

\section{A.3.1.1 Deviations}

There was one deviation to the CAIP requirements. The biased sample was not collected between the two detonation pits, but was collected $1 \mathrm{ft}$ east of the eastern detonation pit. This relocation was done because biasing factors during the field investigation indicated elevated radiological surface activity east of the eastern detonation pit. There were no biasing factors identified in the field to select a sample location between the pits, despite numerous attempts of scanning the surface soils with the electra. This deviation did not adversely impact the completeness of the effort and CAIP requirements were met. 


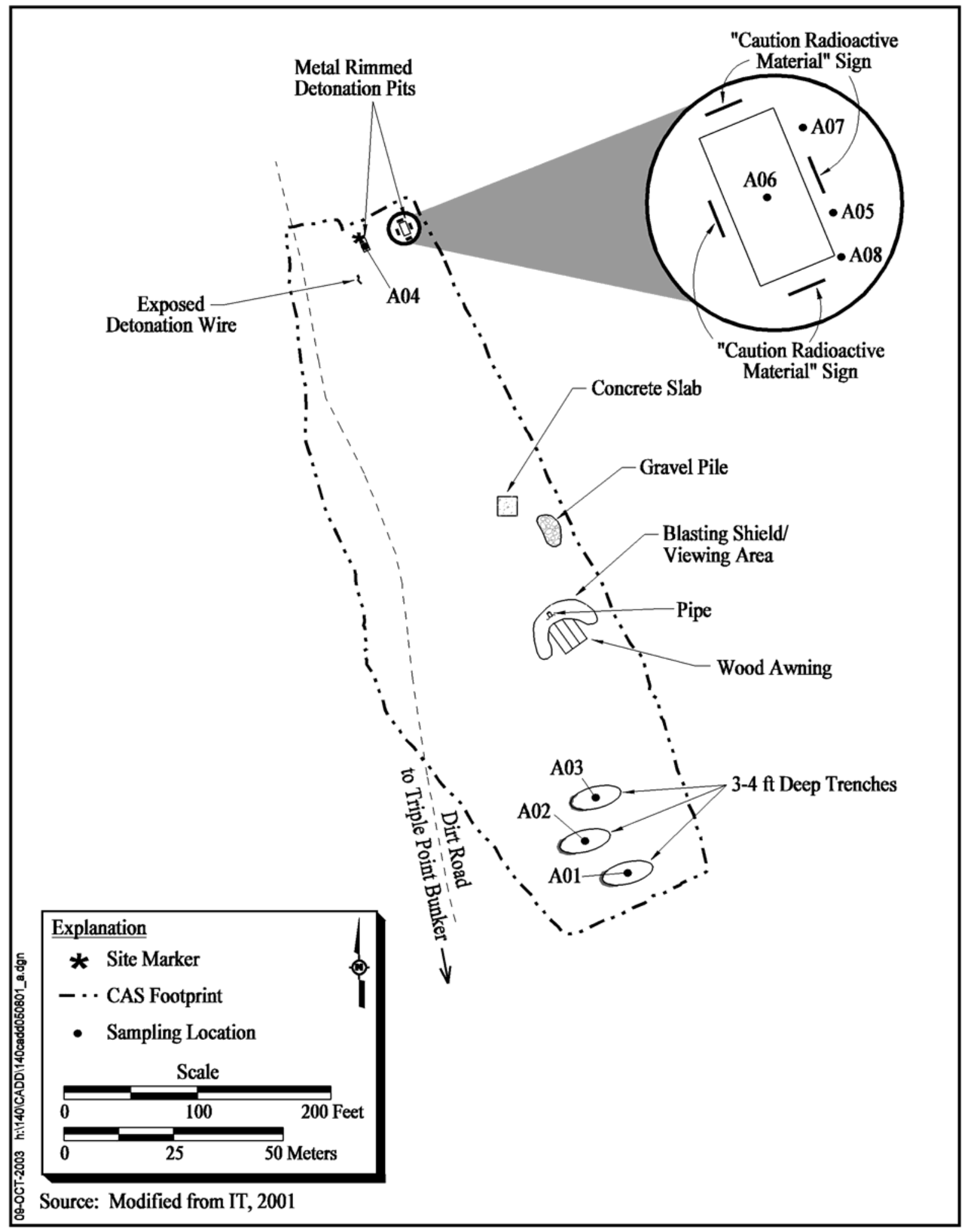

Figure A.3-1

Sample Locations and Points of Interest at CAS 05-08-01, Detonation Pits 
Table A.3-1

Samples Collected at CAS 05-08-01, Detonation Pits

\begin{tabular}{||c|c|c|c|c|c||}
\hline $\begin{array}{c}\text { Sample } \\
\text { Number }\end{array}$ & Borehole & $\begin{array}{c}\text { Depth } \\
\text { (ft bgs) }\end{array}$ & $\begin{array}{c}\text { Sample } \\
\text { Matrix }\end{array}$ & Purpose & Analyses \\
\hline \hline $140 \mathrm{~A} 001$ & $\mathrm{~A} 01$ & $0-1$ & Soil & SC & Set 1 \\
\hline $140 \mathrm{~A} 002$ & $\mathrm{~A} 02$ & $0-1$ & Soil & SC & Set 1 \\
\hline $140 \mathrm{~A} 003$ & $\mathrm{~A} 03$ & $0-1$ & Soil & SC & Set 1 \\
\hline $140 \mathrm{~A} 004$ & $\mathrm{~A} 04$ & $0-1$ & Soil & SC & Set 1 \\
\hline $140 \mathrm{~A} 005$ & $\mathrm{~A} 05$ & $0-1$ & Soil & SC & Set 1 \\
\hline $140 \mathrm{~A} 006$ & $\mathrm{~A} 06$ & $0-1$ & Soil & SC & Set 1 \\
\hline $140 \mathrm{~A} 007$ & $\mathrm{~A} 07$ & $0-1$ & Soil & SC & RCRA Metals \\
\hline $140 \mathrm{~A} 008$ & $\mathrm{~A} 07$ & $2-3$ & Soil & SC & RCRA Metals \\
\hline $140 \mathrm{~A} 009$ & $\mathrm{~A} 08$ & $0-1$ & Soil & SC & RCRA Metals \\
\hline $140 \mathrm{~A} 010$ & $\mathrm{~A} 08$ & $2-3$ & Soil & SC & RCRA Metals \\
\hline $140 \mathrm{~A} 011$ & $\mathrm{~A} 06$ & $2-3$ & Soil & SC & RCRA Metals \\
\hline $140 \mathrm{~A} 012$ & A05 & $2-3$ & Soil & SC & RCRA Metals \\
\hline $140 \mathrm{~A} 301$ & NA & NA & Water & Trip Blank & Total VOCs \\
\hline
\end{tabular}

Set 1 = Total VOCs, Total SVOCs, Explosives, Polychlorinated Biphenyls, Total RCRA Metals, Gamma Spectrometry, Isotopic Plutonium, Isotopic Uranium, and Strontium-90

$\mathrm{ft}$ bgs $=$ Feet below ground surface

$\mathrm{SC}=$ Site characterization

$\mathrm{NA}=$ Not applicable

\section{A.3.2 Investigation Results}

The following sections provide specific details of the soil sampling, field-screening results, and sample selection for laboratory analysis.

\section{A.3.2.1 Hand Sampling}

Hand sampling was conducted using disposable scoops to collect surface soil samples at the biased locations presented in the CAIP. A total of 12 soil samples were collected at this CAS. Six were from surface (0-1 ft) locations as specified in the CAIP. Samples were collected at two step-out locations (A07 and A08) at 0 to $1 \mathrm{ft}$ and 2 to $3 \mathrm{ft} \mathrm{bgs,} \mathrm{and} \mathrm{at} \mathrm{two} \mathrm{of} \mathrm{the} \mathrm{original} \mathrm{surface} \mathrm{sample}$ locations (A05 and A06) from 2 to $3 \mathrm{ft}$. bgs. A hand auger was used to access the sample horizon from 2 to $3 \mathrm{ft}$ bgs, then the sample was collected by hand using a disposable scoop. The two step-out 
locations were selected approximately $5 \mathrm{ft}$ northeast and $5 \mathrm{ft}$ southeast of location A05. See Table A.3-1 for the analytical suite and depth and Figure A.3-1 for sample locations.

\section{A.3.2.2 Inspection of Gravel Pile}

A backhoe was used to explore the subsurface area beneath the gravel pile in the central area of the CAS. No debris was found within or beneath the gravel. Furthermore, the soil beneath the gravel did not indicate a previous disturbance; therefore, no sampling was conducted at this location.

\section{A.3.2.3 Field-Screening Results}

Soil samples were field screened for VOCs and alpha and beta/gamma radiation. The field-screening results (FSRs) were compared to field-screening levels to guide sampling decisions. No VOC headspace FSLs were exceeded during sampling at any of the locations. Several samples exceeded FSLs for alpha and beta/gamma radiation; however, no step-out sampling was conducted for radiological parameters at that time. Based on laboratory results, additional step-out sampling was conducted.

\section{A.3.2.4 Sample Analyses}

Investigation samples were analyzed for CAIP-specified COPCs which included total VOCs, total semivolatile organic compounds (SVOCs), total RCRA metals, explosives, polychlorinated biphenyls (PCBs), isotopic uranium, isotopic plutonium, Sr-90, and gamma-emitting radionuclides. The analytical parameters and laboratory analytical methods used to analyze the investigation samples are listed in Table A.2-1. Table A.3-1 lists the sample-specific analytical parameters.

\section{A.3.2.5 Analytes Detected Above Minimum Reporting Limits}

The parameters detected at concentrations exceeding the MRLs as presented in the CAIP (NNSA/NV, 2002a) are summarized in the following sections. These results were compared to PALs (also established in the CAIP) that are a subset of those that exceed MRLs. A portion of the analytical results were rejected; however, the rejected data did not impact closure decisions as discussed in Appendix B, Section B.1.1.4. 


\section{A.3.2.5.1 Total Volatile Organic Compound Analytical Results for Soil Samples}

Toluene was the only VOC detected in soil samples at concentrations exceeding MRLs and is listed in Table A.3-2. This result did not exceed the PAL.

Table A.3-2

Soil Sample Results for Total VOCs Detected Above Minimum Reporting Limits at CAS 05-08-01

\begin{tabular}{|c|c|c|c|}
\hline \multirow{2}{*}{$\begin{array}{l}\text { Sample } \\
\text { Number }\end{array}$} & \multirow{2}{*}{$\begin{array}{l}\text { Sample } \\
\text { Location }\end{array}$} & \multirow{2}{*}{$\begin{array}{c}\text { Depth } \\
\text { (ft bgs) }\end{array}$} & Contaminants of Potential Concern $(\mu \mathrm{g} / \mathrm{kg})$ \\
\hline & & & Toluene \\
\hline \multicolumn{3}{|c|}{ Preliminary Action Levels ${ }^{a}$} & 520,000 \\
\hline$\overline{140 \mathrm{~A} 003}$ & $\overline{\mathrm{A} \text { A03 }}$ & $\overline{0-1}$ & $\overline{5.1}$ \\
\hline
\end{tabular}

aBased on U.S. Environmental Protection Agency, Region 9 Preliminary Remediation Goals (PRGs) (EPA, 2000)

$\mathrm{ft}$ bgs $=$ Feet below ground surface

$\mu \mathrm{g} / \mathrm{kg}=$ Micrograms per kilogram

\section{A.3.2.5.2 Total Semivolatile Organic Compound Analytical Results for Soil Samples}

Total SVOCs analytical results for soil exceeding the MRLs are shown in Table A.3-3. Results did not exceed the PALs.

Table A.3-3

Soil Sample Results for Total SVOCs Detected Above Minimum Reporting Limits at CAS 05-08-01

\begin{tabular}{|c|c|c|c|}
\hline \multirow{2}{*}{$\begin{array}{c}\text { Sample } \\
\text { Number }\end{array}$} & \multirow{2}{*}{$\begin{array}{c}\text { Sample } \\
\text { Location }\end{array}$} & $\begin{array}{c}\text { Depth } \\
\text { (ft bgs) }\end{array}$ & Contaminants of Potential Concern $(\mu \mathbf{g} / \mathbf{k g})$ \\
\cline { 4 - 4 } & & 2,4-Dinitrotoluene \\
\hline \multicolumn{2}{|c|}{ Preliminary Action Levels ${ }^{\mathrm{a}}$} & $\mathbf{1 , 8 0 0 , 0 0 0}$ \\
\hline \hline $140 \mathrm{~A} 004$ & $\mathrm{~A} 04$ & $0-1$ & 510 \\
\hline $140 \mathrm{~A} 006$ & $\mathrm{~A} 06$ & $0-1$ & 400 \\
\hline
\end{tabular}

aBased on U.S. Environmental Protection Agency, Region 9 Preliminary Remediation Goals (PRGs) (EPA, 2000)

$\mathrm{ft}$ bgs $=$ Feet below ground surface $\mu \mathrm{g} / \mathrm{kg}=$ Micrograms per kilogram 


\section{A.3.2.5.3 Total Petroleum Hydrocarbon Analytical Results for Soil Samples}

TPH analytical results for soil samples did not exceed MRLs.

\section{A.3.2.5.4 Total RCRA Metals Analytical Results for Soil Samples}

Total RCRA metals detected in soil samples above MRLs are shown in Table A.3-4. The result that exceeds the PALs is listed in bold text.

Lead was detected at $1,900 \mathrm{mg} / \mathrm{kg}$ in surficial soil collected at location A05 (sample 140A005). A TCLP analysis was performed on this soil sample to aid in waste management decisions. The TCLP result indicated $4.3 \mathrm{mg} / \mathrm{L}$ lead, which is below the disposal regulation of $5.0 \mathrm{mg} / \mathrm{L}$ (CFR, 2002a); therefore, the material is not considered hazardous. Analytical results from the soil samples did not indicate COCs to be present at 2 to $3 \mathrm{ft}$ bgs at location A05 or any of the step-out locations (A06, A07, or A08).

Table A.3-4

Soil Sample Results for Total RCRA Metals Detected Above Minimum Reporting Limits at CAS 05-08-01

\begin{tabular}{|c|c|c|c|c|c|c|c|c|}
\hline \multirow{2}{*}{$\begin{array}{l}\text { Sample } \\
\text { Number }\end{array}$} & \multirow{2}{*}{$\begin{array}{c}\text { Sample } \\
\text { Location }\end{array}$} & \multirow{2}{*}{$\begin{array}{c}\text { Depth } \\
\text { (ft bgs) }\end{array}$} & \multicolumn{6}{|c|}{ Contaminants of Potential Concern $(\mathrm{mg} / \mathrm{kg})$} \\
\hline & & & Arsenic & Barium & Chromium & Lead & Selenium & Silver \\
\hline \multicolumn{3}{|c|}{ Preliminary Action Levels ${ }^{a}$} & 23 & 100,000 & 450 & 750 & 10,000 & 10,000 \\
\hline $140 \mathrm{A001}$ & $\overline{\mathrm{A} 01}$ & $0-1$ & 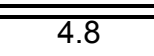 & 140 & $\overline{6.8}$ & $\overline{10}$ & 0.82 & -- \\
\hline 140A002 & A02 & $0-1$ & 3.8 & 98 & 4.6 & 10 & 0.51 & -- \\
\hline $140 \mathrm{~A} 003$ & $\mathrm{~A} 03$ & $0-1$ & 5.2 & 170 & 9.5 & 14 & 0.64 & -- \\
\hline 140A004 & A04 & $0-1$ & 3.3 & 120 & 6.3 & 8.6 & 0.59 & -- \\
\hline 140A005 & A05 & $0-1$ & 3.6 & 99 & 8.9 & 1,900 & 0.81 & 1.2 \\
\hline 140A006 & A06 & $0-1$ & 3.7 & 110 & 13 & 22 & 0.55 & -- \\
\hline $140 \mathrm{~A} 007$ & \multirow{2}{*}{$\mathrm{A} 07$} & $0-1$ & 3.1 & 110 & 4.3 & 7.4 & -- & -- \\
\hline 140A008 & & $2-3$ & 3.4 & 110 & 4.5 & 9.7 & -- & -- \\
\hline 140A009 & \multirow{2}{*}{ A08 } & $0-1$ & 3.4 & 91 & 4.6 & 8.1 & -- & -- \\
\hline $140 \mathrm{~A} 010$ & & $2-3$ & 3.3 & 87 & 4.3 & 5.9 & -- & -- \\
\hline $140 \mathrm{~A} 011$ & $\bar{A} 06$ & $2-3$ & 3.3 & 93 & 5.6 & 8.9 & -- & -- \\
\hline $140 \mathrm{~A} 012$ & A05 & $2-3$ & 3.4 & 97 & 4.3 & 16 & -- & -- \\
\hline
\end{tabular}

aBased on U.S. Environmental Protection Agency, Region 9 Preliminary Remediation Goals (PRGs) (EPA, 2000). Arsenic is the mean plus two times the standard deviation of the mean for sediment samples collected by the Nevada Bureau of Mines and Geology (NBMG) throughout the Nevada Test and Training Range (NTTR) (NBMG, 1998; Moore, 1999)

$\mathrm{ft}$ bgs $=$ Feet below ground surface $\mathrm{mg} / \mathrm{kg}=$ Milligrams per kilogram

-- = Not detected above minimum reporting limit 


\section{A.3.2.5.5 Polychlorinated Biphenyl Analytical Results for Soil Samples}

The PCB analytical results for soil did not exceed the MRLs.

\section{A.3.2.5.6 Explosives}

Explosives analytical results exceeding MRLs are shown in Table A.3-5. None of the detected explosives exceeded PALs.

Table A.3-5

Soil Samples Results for Explosives Detected Above Minimum Reporting Limits at CAS 05-08-01

\begin{tabular}{|c|c|c|c|c|c|c|c|c|c|}
\hline \multirow[b]{2}{*}{$\begin{array}{l}\text { Sample } \\
\text { Number }\end{array}$} & \multirow[b]{2}{*}{$\begin{array}{l}\text { Sample } \\
\text { Location }\end{array}$} & \multirow[b]{2}{*}{$\begin{array}{c}\text { Depth } \\
\text { (ft bgs) }\end{array}$} & \multicolumn{7}{|c|}{ Contaminants of Potential Concern (mg/kg) } \\
\hline & & & 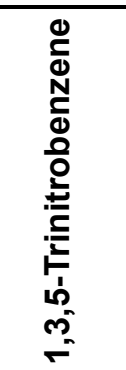 & 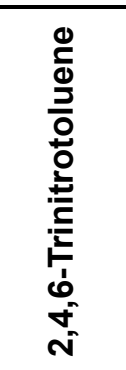 & 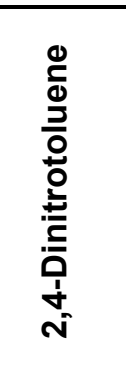 & 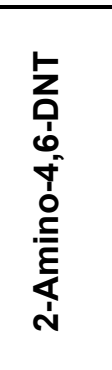 & 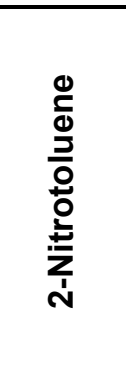 & 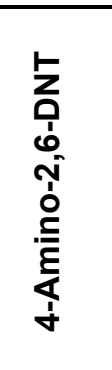 & $\sum_{\text {I }}^{x}$ \\
\hline \multicolumn{3}{|c|}{ Preliminary Action Levels ${ }^{a}$} & 26,000 & 82,000 & 1,800 & NI & 1,000 & NI & 44,000 \\
\hline $1 \overline{140 \mathrm{~A} 004}$ & $\overline{\mathrm{A} 04}$ & $0-1$ & 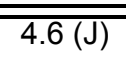 & $\overline{44.1}$ & $\overline{0.72}$ & $\overline{1.6(\mathrm{~J})}$ & $\overline{---}$ & $\overline{\overline{1.1(\mathrm{~J})}}$ & $23(\mathrm{~J})$ \\
\hline $140 \mathrm{~A} 005$ & A05 & $0-1$ & -- & -- & -- & -- & -- & -- & 6.6 \\
\hline $140 \mathrm{~A} 006$ & A06 & $0-1$ & $2.7(\mathrm{~J})$ & 6.3 & $0.72(\mathrm{~J})$ & 0.88 & $0.25(\mathrm{~J})$ & 0.81 & 4.7 \\
\hline
\end{tabular}

aBased on U.S. Environmental Protection Agency, Region 9 Preliminary Remediation Goals (PRGs) (EPA, 2000)

$\mathrm{J}=$ Estimated value. Qualifier added to laboratory data; record accepted. Serial dilution \%D outside of control limits.

$\mathrm{ft}$ bgs $=$ Feet below ground surface

$\mathrm{mg} / \mathrm{kg}=$ Milligrams per kilogram

$--=$ Not detected above minimum reporting limit

$\mathrm{NI}=$ Not identified

\section{A.3.2.5.7 Gamma Spectrometry Results for Soil Samples}

Gamma spectrometry analytical results for soil that exceed the MRLs and PALs are shown in Table A.3-6. Results that are listed in bold text exceed the PALs. Thorium-234 and U-235 are present above the PALs at location A05 at the surface ( 0 to $1 \mathrm{ft} \mathrm{bgs),} \mathrm{and} \mathrm{Th-234} \mathrm{is} \mathrm{also} \mathrm{present} \mathrm{above}$ the PAL in the deeper ( 2 to $3 \mathrm{ft}$ bgs) sample interval. 
Table A.3-6

Soil Sample Results for Gamma-Emitting Radionuclides Detected Above Minimum Reporting Limit at CAS 05-08-01

\begin{tabular}{|c|c|c|c|c|c|c|c|c|c|c|c|c|}
\hline \multirow[b]{2}{*}{$\begin{array}{l}\text { Sample } \\
\text { Number }\end{array}$} & \multirow[b]{2}{*}{$\begin{array}{c}\text { Sample } \\
\text { Location }\end{array}$} & \multirow[b]{2}{*}{$\begin{array}{c}\text { Depth } \\
\text { (ft bgs) }\end{array}$} & \multicolumn{10}{|c|}{ Contaminants of Potential Concern (pCi/g) } \\
\hline & & & 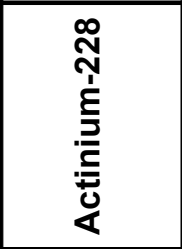 & 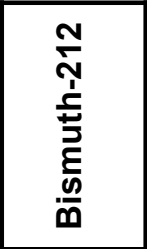 & 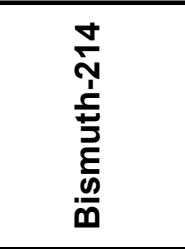 & $\frac{\substack{m \\
\bar{g}}}{\frac{5}{5}}$ & 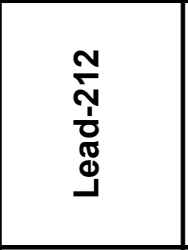 & 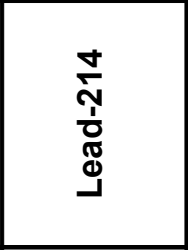 & 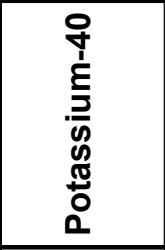 & 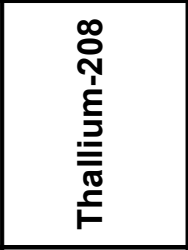 & 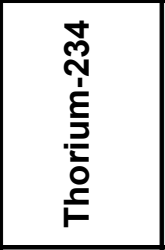 & 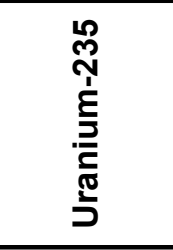 \\
\hline \multicolumn{3}{|c|}{ Preliminary Action Levels } & $3.64^{\mathrm{a}}$ & $3.64^{\mathrm{a}}$ & $3.47^{\mathrm{a}}$ & $7.033^{b}$ & $3.64^{\mathrm{a}}$ & $3.47^{\mathrm{a}}$ & $97.7^{\mathrm{a}}$ & $3.38^{\mathrm{a}}$ & $3.47^{\mathrm{a}}$ & $0.07^{\mathrm{a}}$ \\
\hline $140 \mathrm{~A} 001$ & $\mathrm{~A} 01$ & $0-1$ & $1.46 \pm 0.37$ & -- & $0.82 \pm 0.23$ & $0.3 \pm 0.11$ & $1.95 \pm 0.37$ & $1.28 \pm 0.27$ & $25 \pm 4.8$ & $0.45 \pm 0.13$ & -- & -- \\
\hline 140A002 & $\mathrm{A} 02$ & $0-1$ & $1.95 \pm 0.39$ & -- & $0.79 \pm 0.19$ & $0.219 \pm 0.069$ & $1.92 \pm 0.35$ & $1.04 \pm 0.21$ & $28.3 \pm 4.9$ & $0.57 \pm 0.12$ & -- & -- \\
\hline 140A003 & $\mathrm{A} 03$ & $0-1$ & $1.61 \pm 0.42$ & -- & $1.14 \pm 0.31$ & $1.03 \pm 0.24$ & $1.7 \pm 0.35$ & $1.32 \pm 0.31$ & $25.5 \pm 5.1$ & $0.68 \pm 0.18$ & -- & -- \\
\hline $140 \mathrm{~A} 004$ & A04 & $0-1$ & $1.5 \pm 0.37$ & -- & $1.03 \pm 0.25$ & -- & $1.85 \pm 0.36$ & $1.08 \pm 0.24$ & $28 \pm 5.3$ & $0.56 \pm 0.14$ & -- & -- \\
\hline 140A005 & A05 & $0-1$ & $1.58 \pm 0.35$ & -- & $0.94 \pm 0.22$ & -- & $1.69 \pm 0.33$ & $1.07 \pm 0.23$ & $26.9 \pm 4.7$ & $0.51 \pm 0.12$ & $138 \pm 23$ & $2.34 \pm 0.59$ \\
\hline 140A006 & A06 & $0-1$ & $1.62 \pm 0.37$ & $2.6 \pm 1.1$ & $0.93 \pm 0.22$ & $0.254 \pm 0.091$ & $1.96 \pm 0.37$ & $1.07 \pm 0.23$ & $24 \pm 4.5$ & $0.56 \pm 0.13$ & -- & -- \\
\hline 140A007 & \multirow{2}{*}{$\mathrm{A} 07$} & $0-1$ & $1.7 \pm 0.55$ & -- & $0.86 \pm 0.35$ & -- & $1.61 \pm 0.40$ & $0.98 \pm 0.29$ & $24.7 \pm 6.0$ & $0.59 \pm 0.20$ & -- & -- \\
\hline 140A008 & & $2-3$ & $2.01 \pm 0.49$ & -- & $0.92 \pm 0.29$ & -- & $2 \pm 0.39$ & $1.07 \pm 0.26$ & $27.6 \pm 5.4$ & $0.55 \pm 0.16$ & -- & -- \\
\hline $140 A 009$ & \multirow{2}{*}{ A08 } & $0-1$ & $2.11 \pm 0.59$ & -- & -- & -- & $1.7 \pm 0.42$ & $1.04 \pm 0.30$ & $22.2 \pm 5.6$ & $0.53 \pm 0.20$ & -- & -- \\
\hline 140A010 & & $2-3$ & $1.98 \pm 0.61$ & -- & $0.9 \pm 0.35$ & -- & $2.03 \pm 0.46$ & $1.19 \pm 0.32$ & $27.9 \pm 6.2$ & $0.64 \pm 0.20$ & -- & -- \\
\hline $140 \mathrm{~A} 011$ & A06 & $2-3$ & $1.79 \pm 0.45$ & -- & -- & -- & $2.08 \pm 0.41$ & $1.01 \pm 0.26$ & $26.9 \pm 5.2$ & $0.5 \pm 0.15$ & -- & -- \\
\hline 140A012 & A05 & $2-3$ & $1.87 \pm 0.62$ & -- & -- & -- & $1.69 \pm 0.43$ & $1.17 \pm 0.33$ & $23.3 \pm 5.7$ & $0.64 \pm 0.22$ & $30.5 \pm 5.5$ & -- \\
\hline
\end{tabular}

aBased on background concentration listed in Environmental Monitoring Report for the Proposed Ward Valley, California, Low-Level Radioactive Waste (LLRW) Facility (US Ecology and Atlan-Tech, 1992)

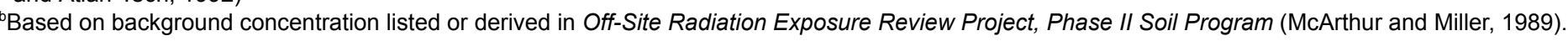

$\mathrm{ft}$ bgs $=$ Feet below ground surface

$\mathrm{pCi} / \mathrm{g}=$ Picocuries per gram

$--=$ Not detected above minimum reporting limits 


\section{A.3.2.5.8 Isotopic Uranium Analytical Results for Soil Samples}

Isotopic uranium analytical results for soil samples detected above MRLs are shown in Table A.3-7. Results that are listed in bold text exceed the PALs. Based on the normalized difference test discussed in Section A.2.7, U-235 is not above the PAL at location A05; however, U-238 is above the PAL at this location.

\section{A.3.2.5.9 Isotopic Plutonium Analytical Results for Soil Samples}

Isotopic plutonium analytical results for soil samples detected above MRLs are shown in Table A.3-7. Locations A01 and A03 have Pu-239 concentrations above PALs; however, due to atmospheric testing in Area 5 these isotopes are not considered to be related to activities conducted at CAS 05-08-01 (McArthur and Mead, 1989). See Section A.2.7.1 for further information.

\section{A.3.2.5.10 Strontium-90 Analytical Results for Soil Samples}

Strontium-90 was not detected in soil samples above MRLs.

\section{A.3.2.6 Contaminants of Concern}

Based on the CAS 05-08-01 analytical results, COCs are present in the soils at location A05. The COCs are lead and the radioisotopes Th-234, U-238, and U-235.

\section{A.3.3 Nature and Extent of Contaminants of Concern}

The COCs lead and the radioisotopes Th-234, U-238, and U-235 were found in surface soils at location A05. The lead concentration decreased with depth to a concentration below PALs at 2 to $3 \mathrm{ft}$ bgs. The U-238 and U-235 concentrations decreased with depth and were below PALs at 2 to $3 \mathrm{ft}$ bgs. The Th-234 concentration decreased with depth but were still above PALs in the sample collected at 2 to $3 \mathrm{ft}$ bgs; however, the concentration decreased by an order of magnitude within the 2-ft interval. Based on the decrease in concentration with depth, the Th-234 concentration is expected to be below PALs at a depth of $4 \mathrm{ft}$ bgs. A confirmation sample should be collected during closure activities to confirm no COCs remain at this location. Sample results from the step-out locations (A06, A07, and A08) indicate lead and radioisotope concentrations have not migrated more than $5 \mathrm{ft}$ laterally at concentrations that exceed the PALs. 
Table A.3-7

Soil Sample Results for Isotopes Detected

Above Minimum Reporting Limits at CAS 05-08-01

\begin{tabular}{|c|c|c|c|c|c|c|}
\hline \multirow{2}{*}{$\begin{array}{l}\text { Sample } \\
\text { Number }\end{array}$} & \multirow{2}{*}{$\begin{array}{c}\text { Sample } \\
\text { Location }\end{array}$} & \multirow{2}{*}{$\begin{array}{c}\text { Depth } \\
\text { (ft bgs) }\end{array}$} & \multicolumn{4}{|c|}{ Contaminants of Potential Concern (pCi/g) } \\
\hline & & & Uranium-234 ${ }^{\mathrm{a}}$ & Uranium-235 ${ }^{\mathrm{a}}$ & Uranium-238 ${ }^{\mathrm{b}}$ & Plutonium-239 \\
\hline \multicolumn{3}{|c|}{ Preliminary Action Levels } & 3.47 & 0.07 & 3.47 & 0.106 \\
\hline $140 \mathrm{A001}$ & $\overline{\mathrm{A} 01}$ & $\overline{0-1}$ & $\overline{1.05 \pm 0.16}$ & $0.055 \pm 0.025$ & $0.95 \pm 0.15$ & $0.52 \pm 0.11$ \\
\hline $140 \mathrm{~A} 002$ & A02 & $0-1$ & $0.91 \pm 0.14$ & $0.066 \pm 0.025$ & $0.91 \pm 0.14$ & $0.067 \pm 0.032$ \\
\hline $140 \mathrm{~A} 003$ & A03 & $0-1$ & $1.03 \pm 0.16$ & $0.112 \pm 0.036$ & $0.9 \pm 0.14$ & $0.51 \pm 0.12$ \\
\hline $140 \mathrm{~A} 004$ & A04 & $0-1$ & $0.83 \pm 0.13$ & $0.05 \pm 0.023$ & $0.91 \pm 0.14$ & 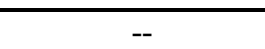 \\
\hline $140 \mathrm{~A} 005$ & A05 & $0-1$ & $2.13 \pm 0.54$ & -- & $11.9 \pm 1.9$ & -- \\
\hline $140 \mathrm{~A} 006$ & A06 & $0-1$ & $1.13 \pm 0.17$ & $0.12 \pm 0.037$ & $2.03 \pm 0.28$ & -- \\
\hline 140A007 & \multirow{2}{*}{ A07 } & $0-1$ & $0.86 \pm 0.16$ & -- & $0.81 \pm 0.16$ & -- \\
\hline 140A008 & & $2-3$ & $0.96 \pm 0.17$ & -- & $0.9 \pm 0.16$ & -- \\
\hline 140A009 & \multirow{2}{*}{ A08 } & $0-1$ & $0.84 \pm 0.16$ & -- & $0.95 \pm 0.18$ & -- \\
\hline $140 \mathrm{~A} 010$ & & $2-3$ & $0.84 \pm 0.15$ & -- & $0.91 \pm 0.16$ & -- \\
\hline $140 \mathrm{~A} 011$ & A06 & $2-3$ & $0.87 \pm 0.17$ & -- & $1.15 \pm 0.21$ & -- \\
\hline $140 \mathrm{~A} 012$ & A05 & $2-3$ & $1.21 \pm 0.21$ & $0.067 \pm 0.036$ & $3.55 \pm 0.52$ & -- \\
\hline
\end{tabular}

aBased on background concentration listed in Environmental Monitoring Report for the Proposed Ward Valley, California, Low-Level Radioactive Waste (LLRW) Facility (US Ecology and Atlan-Tech, 1992).

${ }^{b}$ Based on background concentration listed or derived in Off-Site Radiation Exposure Review Project, Phase II Soil Program (McArthur and Miller, 1989).

$\mathrm{ft}$ bgs $=$ Feet below ground surface

$\mathrm{pCi} / \mathrm{g}=$ Picocuries per gram

-- = Not detected above minimum reporting limits

\section{A.3.4 Revised Conceptual Site Model}

Biased soil samples were collected in accordance with the CAIP and successfully delineated the lateral and vertical extent of COCs. The data did not show variations to the CSM; therefore, no modifications are necessary. 


\section{A.4.0 Debris Pits (CAS 05-08-02)}

Corrective Action Site 05-08-02 is located on the 5-08 Road approximately 2 mi north of the Mercury Highway and 5-01 Road intersection. There is a large area mounded on all sides that resembles an old evaporation pond. This area contains two pipes, a partially buried drum almost underneath one of the pipes, and the remnants of a weir gate. The site includes a small amount of surface and partially buried debris. The debris includes aerosol cans, paint cans, an old fire extinguisher, pipes, metal mesh, cables, ripper teeth, a rusted tool box, a white cabinet, tires, fuel/oil filters, wood, metal, construction debris, and wire. A geophysical survey did not identify buried debris. The terrain is rough and uneven, and the vegetation is sparse but healthy. Additional detail is provided in the CAIP (NNSA/NV, 2002a).

\section{A.4.1 Corrective Action Investigation}

Eleven investigation samples and associated QC samples, listed in Table A.4-1, were collected during the CAI conducted at CAS 05-08-02. The actual sample locations correspond with the planned sample locations identified in the CAIP and are shown in Figure A.4-1. The specific CAI activities conducted to meet CAIP requirements at CAS 05-08-02 are described in the following sections.

\section{A.4.1.1 Deviations}

There were no deviations; therefore, the CAIP requirements were met.

\section{A.4.2 Investigation Results}

The following sections provide CAS-specific details of the sampling, FSRs, and sample selection and analysis.

\section{A.4.2.1 Hand Sampling}

Hand sampling was conducted using disposable scoops to access sampling horizons and collect samples at the biased locations presented in the CAIP. A total of 11 soil samples were collected at this CAS. Eight were from surface (0 to $1 \mathrm{ft}$ ) locations as specified in the CAIP. Locations B02 and B03 also were sampled at 3 to $4 \mathrm{ft}$ bgs as specified in the CAIP. The eleventh sample was collected at 
Table A.4-1

Samples Collected at CAS 05-08-02, Debris Pits

\begin{tabular}{|c|c|c|c|c|c||}
\hline $\begin{array}{c}\text { Sample } \\
\text { Number }\end{array}$ & Borehole & $\begin{array}{c}\text { Depth } \\
\text { (ft bgs) }\end{array}$ & $\begin{array}{c}\text { Sample } \\
\text { Matrix }\end{array}$ & Purpose & Analyses \\
\hline \hline 140B001 & B01 & $0-1$ & Soil & SC & Set 2 \\
\hline 140B002 & B02 & $0-1$ & Soil & SC & Set 2 \\
\hline 140B003 & B03 & $0-1$ & Soil & SC & Set 2 \\
\hline 140B004 & B04 & $0-1$ & Soil & SC & Set 2 \\
\hline 140B005 & B05 & $0-1$ & Soil & SC & Set 2 \\
\hline 140B006 & B02 & $3-4$ & Soil & SC, Lab QC & Set 2 \\
\hline 140B007 & B03 & $3-4$ & Soil & SC & Set 2 \\
\hline 140B302 & B03 & $3-4$ & Soil & Field Duplicate & of 140B007 \\
\hline 140B008 & B06 & $0-1$ & Soil & SC & Set 2 \\
\hline 140B009 & B07 & $0-1$ & Soil & SC & Set 2 \\
\hline 140B010 & B08 & $0-1$ & Soil & SC & Set 2 \\
\hline 140B012 & B06 & $1-1.5$ & Soil & SC & TPH-DRO \\
\hline 140B301 & NA & NA & Water & Trip Blank & Total VOCs \\
\hline 140B303 & NA & NA & Water & Trip Blank & Total VOCs \\
\hline
\end{tabular}

Set 2 = Total VOCs, Total SVOCs, PCBs, TPH (DRO and GRO), and Total RCRA Metals

$\mathrm{ft}$ bgs $=$ Feet below ground surface

$\mathrm{SC}=$ Site characterization

NA $=$ Not applicable

$\mathrm{QC}=$ Quality control

location B06 from 1 to $1.5 \mathrm{ft}$ bgs. This location was selected because an oil filter had been removed and the underlying soil was discolored. The initial sample at this location ( 0 to $1 \mathrm{ft}$ bgs) contained $\mathrm{DRO}$ at concentrations exceeding the PAL. The location was resampled from 1 to $1.5 \mathrm{ft}$ bgs after removing the discolored soil and results showed DRO to be below the PAL. In addition, one laboratory QC and one field duplicate were collected and analyzed.

A power auger was used to access the sample horizon from 3 to $4 \mathrm{ft}$ bgs, then the sample was collected by hand using a disposable scoop. See Table A.4-1 for the analytical suite and depths and Figure A.4-1 for sample locations. 


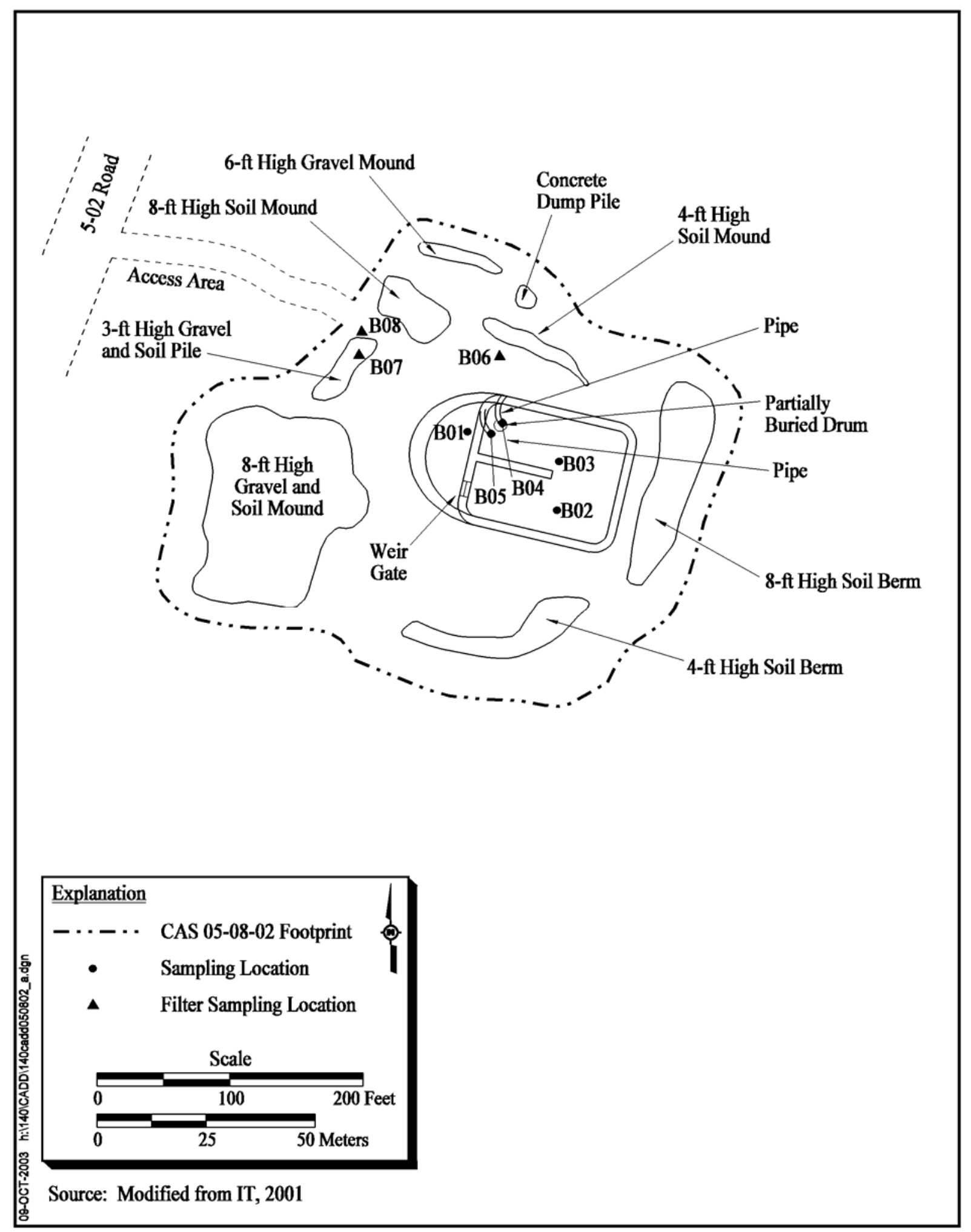

Figure A.4-1

Sampling Locations and Points of Interest at CAS 05-08-02, Debris Pits 


\section{A.4.2.2 Field-Screening Results}

Soil samples were field screened for VOCs and alpha and beta/gamma radiation. The field-screening results were compared to FSLs to guide sampling decisions. The VOC headspace FSLs were not exceeded during hand sampling. In addition, none of the samples had elevated FSLs for alpha and beta/gamma radiation.

\section{A.4.2.3 Sample Analyses}

Investigation samples were analyzed for CAIP-specified COPCs which included total VOCs, total SVOCs, total RCRA metals, TPH (DRO and GRO), and PCBs. Radionuclides were not CAIP-specified COPC; therefore, they were not included in the analytical suite. The analytical parameters and laboratory analytical methods used to analyze the investigation samples are listed in Table A.2-1. Table A.4-1 lists the sample-specific analytical parameters.

\section{A.4.2.4 Analytes Detected Above Minimum Reporting Limits}

The chemicals detected at concentrations exceeding their corresponding MRLs, as established in the CAIP (NNSA/NV, 2002a), are summarized in the following sections. These results were compared to PALs (also established in the CAIP) and are a subset of those that exceed MRLs. This comparison was used to identify the presence of any COC at this CAS. A portion of the analytical results were rejected; however, these rejected data did not adversely impact the DQOs or closure decisions. The data quality is discussed in Appendix B, Section B.1.1.4.

\section{A.4.2.4.1 Total Volatile Organic Compound Analytical Results for Soil Samples}

Total VOCs analytical results for soil samples did not exceed the PALs. Results exceeding MRLs are shown on Table A.4-2.

\section{A.4.2.4.2 Total Semivolatile Organic Compound Analytical Results for Soil Samples}

Total SVOCs analytical results for soil samples did not exceed the MRLs. 
Table A.4-2

Soil Sample Results for Total VOCs Detected Above Minimum Reporting Limits at CAS 05-08-02

\begin{tabular}{|c|c|c|c|c|}
\hline \multirow{2}{*}{$\begin{array}{c}\text { Sample } \\
\text { Number }\end{array}$} & \multirow{2}{*}{$\begin{array}{c}\text { Sample } \\
\text { Location }\end{array}$} & \multirow{2}{*}{$\begin{array}{c}\text { Depth } \\
\text { (ft bgs) }\end{array}$} & \multicolumn{2}{|c|}{ Contaminants of Potential Concern $(\mu \mathbf{g} / \mathbf{k g})$} \\
\cline { 3 - 5 } & & 2-Butanone & Acetone \\
\hline \multicolumn{2}{|c|}{ Preliminary Action Levels ${ }^{\mathrm{a}}$} & $\mathbf{2 8 , 0 0 0 , 0 0 0}$ & $\mathbf{6 , 2 0 0 , 0 0 0}$ \\
\hline \hline $140 \mathrm{~B} 008$ & B06 & $0-1$ & $24(\mathrm{~J})^{\mathrm{b}}$ & $35(\mathrm{~J})^{\mathrm{c}}$ \\
\hline
\end{tabular}

aBased on U.S. Environmental Protection Agency, Region 9 Preliminary Remediation Goals (PRGs) (EPA, 2000)

${ }^{\mathrm{b}} \mathrm{Qualifier}$ added to laboratory data; record accepted. Percent relative standard deviation exceeded $30 \%$.

${ }^{\mathrm{C}} \mathrm{Qualifier}$ added to laboratory data; record accepted. Continuing calibration verification percent $>25 \%$.

$\mathrm{ft}$ bgs $=$ Feet below ground surface

$\mu \mathrm{g} / \mathrm{kg}=$ Micrograms per kilogram

$\mathrm{J}=$ Estimated value

\section{A.4.2.4.3 Total Petroleum Hydrocarbon Analytical Results for Soil Samples}

The TPH analytical results for soil exceeding the MRLs or PALs (indicated in bold) are shown in Table A.4-3. Soil sample 160B008 taken from location B06 had a TPH (DRO) concentration of $720 \mathrm{mg} / \mathrm{kg}$, which exceeded the PAL of $100 \mathrm{mg} / \mathrm{kg}$. This sample was collected from stained soil directly beneath an oil filter. The discolored soil was removed from location B06 and another sample collected at location B06 from 1 to $1.5 \mathrm{ft}$ bgs. This soil sample was submitted for laboratory analyses and the result was $17 \mathrm{mg} / \mathrm{kg}$, well below the PAL of $100 \mathrm{mg} / \mathrm{kg}$. No other analytical results exceeded the PAL.

\section{A.4.2.4.4 Total RCRA Metals Analytical Results for Soil Samples}

Total RCRA metal analytical results for soil exceeding the MRLs are presented in Table A.4-4. The PALs were not exceeded in any sample.

\section{A.4.2.4.5 Polychlorinated Biphenyl Analytical Results for Soil Samples}

The PCB analytical results for soil did not exceed the MRLs. 


\section{Table A.4-3 \\ Soil Sample Results for TPH-DRO Detected Above Minimum Reporting Limits at CAS 05-08-02}

\begin{tabular}{||c|c|c|c||}
\hline \multirow{2}{*}{$\begin{array}{c}\text { Sample } \\
\text { Number }\end{array}$} & \multirow{2}{*}{$\begin{array}{c}\text { Sample } \\
\text { Location }\end{array}$} & $\begin{array}{c}\text { Depth } \\
\text { (ft bgs) }\end{array}$ & Contaminants of Potential Concern (mg/kg) \\
\cline { 3 - 4 } & & & Diesel-Range Organics \\
\hline \multicolumn{2}{|c|}{ Preliminary Action Levels ${ }^{\text {a }}$} & $\mathbf{1 0 0}$ \\
\hline \hline $140 \mathrm{~B} 008$ & $\mathrm{~B} 06$ & $0-1$ & $\mathbf{7 2 0}(\mathrm{J})$ \\
\hline $140 \mathrm{~B} 009$ & $\mathrm{~B} 07$ & $0-1$ & $56(\mathrm{~J})$ \\
\hline $140 \mathrm{~B} 010$ & $\mathrm{~B} 08$ & $0-1$ & $87(\mathrm{~J})$ \\
\hline 140B012 & B06 & $1-1.5$ & $17(\mathrm{~J})$ \\
\hline
\end{tabular}

aBased on U.S. Environmental Protection Agency, Region 9 Preliminary Remediation Goals (PRGs) (EPA, 2000)

$\mathrm{ft}$ bgs $=$ Feet below ground surface

$\mathrm{mg} / \mathrm{kg}=$ Milligrams per kilogram

$\mathrm{J}=$ Estimated value. Qualifier added to laboratory data; record accepted. Total extractable petroleum hydrocarbons result quantitated from diesel standard calibration.

\section{Table A.4-4 \\ Soil Sample Results for Total RCRA Metals Detected Above Minimum Reporting Limits at CAS 05-08-02}

\begin{tabular}{||c|c|c|c|c|c|c|c||}
\hline \multirow{2}{*}{$\begin{array}{c}\text { Sample } \\
\text { Number }\end{array}$} & \multirow{2}{*}{$\begin{array}{c}\text { Sample } \\
\text { Location }\end{array}$} & \multirow{2}{*}{$\begin{array}{c}\text { Depth } \\
\text { (ft bgs) }\end{array}$} & \multicolumn{5}{|c||}{ Contaminants of Potential Concern (mg/kg) } \\
\cline { 5 - 8 } & & Arsenic & Barium & Chromium & Lead & Selenium \\
\hline \multicolumn{2}{|c|}{ Preliminary Action Levels ${ }^{\text {a }}$} & $\mathbf{2 3}$ & $\mathbf{1 0 0 , 0 0 0}$ & $\mathbf{4 5 0}$ & $\mathbf{7 5 0}$ & $\mathbf{1 0 , 0 0 0}$ \\
\hline \hline 140B001 & B01 & $0-1$ & 5.4 & 160 & $6.3(\mathrm{~J})$ & 8.7 & -- \\
\hline 140B002 & B02 & $0-1$ & 7.4 & 250 & $8.9(\mathrm{~J})$ & 10 & -- \\
\hline 140B003 & B03 & $0-1$ & 6.4 & 210 & $8.3(\mathrm{~J})$ & 10 & -- \\
\hline 140B004 & B04 & $0-1$ & 5.2 & 120 & $4.8(\mathrm{~J})$ & 7.1 & -- \\
\hline 140B005 & B05 & $0-1$ & 5 & 140 & $6.1(\mathrm{~J})$ & 15 & -- \\
\hline 140B006 & B02 & $3-4$ & 4.8 & 120 & $5.3(\mathrm{~J})$ & 5.3 & -- \\
\hline 140B007 & B03 & $3-4$ & 6.3 & 200 & $11(\mathrm{~J})$ & 8.7 & 0.54 \\
\hline 140B008 & B06 & $0-1$ & 4.5 & 120 & 5 & 7.9 & -- \\
\hline 140B009 & B07 & $0-1$ & 4.4 & 72 & 4.6 & 5.8 & -- \\
\hline 140B010 & B08 & $0-1$ & 4.7 & 260 & 4.3 & 10 & -- \\
\hline 140B302 & B03 & $3-4$ & 6.1 & 180 & $12(\mathrm{~J})$ & 8.2 & -- \\
\hline
\end{tabular}

\footnotetext{
aBased on U.S. Environmental Protection Agency, Region 9 Preliminary Remediation Goals (PRGs) (EPA, 2000). Arsenic is the mean plus two times the standard deviation of the mean for sediment samples collected by the NBMG throughout NTTR (NBMG, 1998; Moore, 1999)

$\mathrm{ft}$ bgs $=$ Feet below ground surface $\mathrm{mg} / \mathrm{kg}=$ Milligrams per kilogram

$--=$ Not detected above minimum reporting limit

$\mathrm{J}=$ Estimated value. Qualifier added to laboratory data; record accepted. Inductively coupled plasma serial dilution recovery was not met. Value exceeded linear range of instrument.
} 


\section{A.4.2.5 Contaminants of Concern}

Based on the aforementioned analytical results, only the stained soil directly beneath the oil filter at sample location B06 at a depth 0 to $1 \mathrm{ft}$ bgs contained the COC TPH (DRO). The stained soil was removed and the location resampled. No COCs remain at this CAS.

\section{A.4.3 Nature and Extent of Contaminants of Concern}

No COCs remain at this CAS.

\section{A.4.4 Revised Conceptual Site Model}

Biased soil samples were collected in accordance with the CAIP; therefore, no variations to the CSM were identified. 


\section{A.5.0 Hazardous Waste Accumulation Site (Buried) (CAS 05-17-01)}

Corrective Action Site 05-17-01 (Figure A.5-1) is located northwest of Triple Point Bunker, north of the 5-07 Road. Although the term "buried" is part of the CAS description, no buried waste or debris was discovered during the CAI. The site resembles a bunker with the wood support removed, leaving only the soil mound located near the center of the CAS. A fence, interior to the circumference of the CAS boundary, surrounds the area and mound. There is a small amount of debris inside and outside the fencing. Debris found at the site include glass, metal, wood, a respirator, and sun-weathered shoes. Surface staining was observed within the CAS, indicating that materials may have been stored/released on the surface. These areas were sampled. A sign stating "Deposit Lighter and Matches Here" is at the entrance to the dirt road, suggesting flammable material may have been used at this location in the past. Except for the mound, the terrain is flat, and sparsely vegetated. More detail about this CAS is provided in the CAIP (NNSA/NV, 2002a).

\section{A.5.1 Corrective Action Investigation}

Five investigation samples and associated QC samples were collected during investigation activities at this CAS and are listed in Table A.5-1. The actual sample locations correspond with the planned sample locations identified in the CAIP and are shown in Figure A.5-1. The specific CAI activities conducted to meet CAIP requirements at CAS 05-17-01 are described in the following sections.

\section{A.5.1.1 Deviations}

There were no deviations to the CAIP requirements; therefore, the CAIP requirements were met.

\section{A.5.2 Investigation Results}

The following sections provide CAS-specific details of the inspection of the soil mound, soil sampling, FSRs, and sample selection and analysis. 


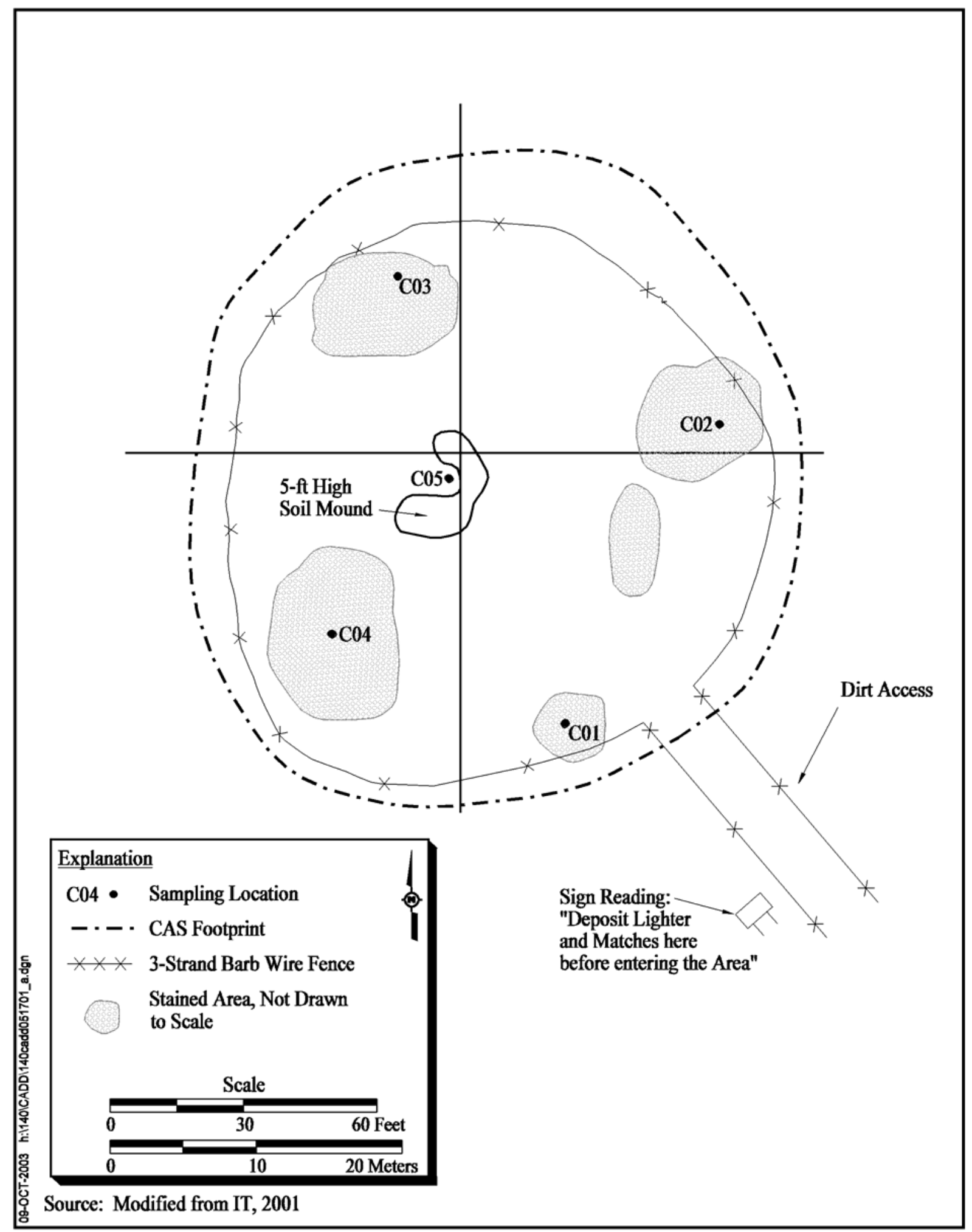

Figure A.5-1

Sampling Locations and Points of Interest at CAS 05-17-01, Hazardous Waste Accumulation Site (Buried) 
Table A.5-1

Samples Collected at CAS 05-17-01, Hazardous Waste Accumulation Site (Buried)

\begin{tabular}{|c|c|c|c|c|c|}
\hline $\begin{array}{l}\text { Sample } \\
\text { Number }\end{array}$ & Borehole & $\begin{array}{c}\text { Depth } \\
\text { (ft bgs) }\end{array}$ & $\begin{array}{c}\text { Sample } \\
\text { Matrix }\end{array}$ & Purpose & Analyses \\
\hline $140 \mathrm{C001}$ & $\mathrm{C01}$ & $0-1$ & Soil & $\overline{\mathrm{SC}}$ & Set 3 \\
\hline $140 \mathrm{C} 002$ & $\mathrm{C} 02$ & $0-1$ & Soil & SC & Set 3 \\
\hline $140 \mathrm{C} 003$ & $\mathrm{C03}$ & $0-1$ & Soil & $\mathrm{SC}$ & Set 3 \\
\hline $140 \mathrm{C} 004$ & $\mathrm{C04}$ & $0-1$ & Soil & $\mathrm{SC}$ & Set 3 \\
\hline $140 \mathrm{C} 005$ & $\mathrm{C05}$ & $0-1$ & Soil & $\mathrm{SC}$ & Set 3 \\
\hline $140 \mathrm{C} 301$ & NA & $\mathrm{NA}$ & Water & Trip Blank & Total VOCs \\
\hline $140 C 302$ & NA & NA & Water & Field Blank & Set 3 \\
\hline
\end{tabular}

Set 3 = Total VOCs, Total SVOCs, PCBs, TPH (DRO and GRO), Pesticides, Beryllium, Explosives, and Total RCRA Metals

$\mathrm{ft}$ bgs $=$ Feet below ground surface

$\mathrm{SC}=$ Site characterization

NA = Not applicable

\section{A.5.2.1 Hand Sampling}

Hand sampling was conducted using disposable scoops to access sampling horizons and collect samples at the biased locations presented in the CAIP. A total of five soil samples were collected at this CAS. All samples were from discolored soil at surface (0 to $1 \mathrm{ft})$ locations as specified in the CAIP. Samples were not collected at any step-out locations. These five soil samples were submitted for laboratory analyses. In addition, one QC field blank was collected and analyzed. The soil samples were collected using a disposable scoop.

\section{A.5.2.2 Inspection of Soil Mound}

A backhoe was used to excavate through the subsurface area beneath the soil mound in the central area of the CAS. There was no debris or soil staining found within or beneath the mound. Furthermore, the soil beneath the mound did not indicate a previous disturbance; therefore, no sampling was conducted within or beneath the soil mound. 


\section{A.5.2.3 Field-Screening Results}

Soil samples were field screened for VOCs and alpha and beta/gamma radiation. The FSRs were compared to FSLs to guide sampling decisions. No VOC headspace or radiation FSLs were exceeded during sampling at any of the locations.

\section{A.5.2.4 Sample Analyses}

Investigation samples were analyzed for CAIP-specified COPCs including total VOCs, total SVOCs, total RCRA metals plus total beryllium, TPH (diesel and gas), explosives, pesticides, and PCBs. Radionuclides were not CAIP-specified COPCs; therefore, were not included in the analytical suite. The analytical parameters and laboratory analytical methods used to analyze the investigation samples are listed in Table A.2-1. Table A.5-1 lists the sample-specific analytical parameters.

\section{A.5.2.5 Analytes Detected Above Minimum Reporting Limits}

The analytical results detected at concentrations exceeding the MRLs as established in the CAIP (NNSA/NV, 2002a) are summarized in the following sections. These results are compared to PALs (also established in the CAIP) and are a subset of those that exceed MRLs. A portion of the analytical results were rejected; however, these rejected data did not adversely impact the DQOs or closure decisions as discussed in Section B.1.1.4 of Appendix B.

\section{A.5.2.5.1 Total Volatile Organic Compound Analytical Results for Soil Samples}

Total VOCs analytical results for soil did not exceed the MRLs.

\section{A.5.2.5.2 Total Semivolatile Organic Compound Analytical Results for Soil Samples}

Total SVOCs analytical results for soil did not exceed the MRLs.

\section{A.5.2.5.3 Total Petroleum Hydrocarbon Analytical Results for Soil Samples}

The TPH (DRO and GRO) analytical results for soil did not exceed the MRLs. 


\section{A.5.2.5.4 Total RCRA Metals Analytical Results for Soil Samples}

Total RCRA metals and total beryllium analytical results for soil samples did not exceed the PALs. Results exceeding MRLs are listed in Table A.5-2.

Table A.5-2

Soil Sample Results for Metals Detected Above Minimum Reporting Limits at CAS 05-17-01

\begin{tabular}{|c|c|c|c|c|c|c|c|}
\hline \multirow{2}{*}{$\begin{array}{l}\text { Sample } \\
\text { Number }\end{array}$} & \multirow{2}{*}{$\begin{array}{c}\text { Sample } \\
\text { Location }\end{array}$} & \multirow{2}{*}{$\begin{array}{c}\text { Depth } \\
\text { (ft bgs) }\end{array}$} & \multicolumn{5}{|c|}{ Contaminants of Potential Concern (mg/kg) } \\
\hline & & & Arsenic & Barium & Beryllium & Chromium & Lead \\
\hline \multicolumn{3}{|c|}{ Preliminary Action Levels $^{a}$} & 23 & 100,000 & 2,200 & 450 & 750 \\
\hline $140 \mathrm{C} 001$ & $\mathrm{C01}$ & $0-1$ & 3.4 & 160 & 0.59 & 6.8 & 12 \\
\hline $140 \mathrm{C} 002$ & $\mathrm{C} 02$ & $0-1$ & 4.5 & 180 & 0.82 & 9.6 & 11 \\
\hline $140 \mathrm{C} 003$ & $\mathrm{C03}$ & $0-1$ & 3.7 & 160 & 0.59 & 6.9 & 11 \\
\hline $140 \mathrm{C} 004$ & $\mathrm{CO4}$ & $0-1$ & 4.2 & 140 & 0.59 & 6.7 & 8.9 \\
\hline $140 \mathrm{C} 005$ & $\mathrm{C05}$ & $0-1$ & 3.4 & 140 & 0.54 & 6.2 & 14 \\
\hline
\end{tabular}

aBased on U.S. Environmental Protection Agency, Region 9 Preliminary Remediation Goals (PRGs) (EPA, 2000). Arsenic is the mean plus two times the standard deviation of the mean for sediment samples collected by the NBMG throughout NTTR (NBMG, 1998; Moore, 1999)

$\mathrm{ft}$ bgs $=$ Feet below ground surface

$\mathrm{mg} / \mathrm{kg}=$ Milligrams per kilogram

\section{A.5.2.5.5 Polychlorinated Biphenyl Results for Soil Samples}

Analytical results for PCBs in soil did not exceed the MRLs.

\section{A.5.2.5.6 Explosives}

Analytical results for explosives in soil did not exceed the MRLs.

\section{A.5.2.5.7 Pesticides}

Analytical results for pesticides in soil did not exceed the MRLs.

\section{A.5.2.6 Contaminants of Concern}

Based on the aforementioned analytical results, no COCs were identified in the soil at this CAS. 


\section{A.5.3 Nature and Extent of Contaminants of Concern}

No COCs were identified in the soil at this CAS.

\section{A.5.4 Revised Conceptual Site Model}

No variations to the CSM were identified. 


\section{A.6.0 Waste Disposal Site (05-19-01)}

Corrective Action Site 05-19-01 is located on the northern edge of Frenchman Lake (Figure A.6-1). The site consists of three separate areas, one of which (the Western Disposal Area) has evidence of burns. Debris was removed at each of the areas on the ground surface and consisted of industrial equipment, construction debris, concrete, metal, wood, and aerosol cans. Asbestos in the form of transite was observed in the debris. A small amount of surface debris remains at this CAS and will be removed as a best management practice during closure activities. A geophysical survey indicated the possible presence of buried debris in the Middle Disposal Area; however, no debris was found during backhoe excavations. More detail about this CAS is provided in the CAIP (NNSA/NV, 2002a).

\section{A.6.1 Corrective Action Investigation}

Eleven investigation samples and associated QC samples were collected during investigation activities at this CAS and are listed in Table A.6-1. The actual sample locations correspond with the planned sample locations identified in the CAIP and are shown in Figure A.6-1. The specific CAI activities conducted to meet CAIP requirements are described in the following sections.

\section{A.6.1.1 Deviations}

There were no deviations to the CAIP requirements; therefore, the CAIP requirements were met.

\section{A.6.2 Investigation Results}

The following sections provide CAS-specific details of the inspection, soil sampling, FSRs, and sample selection and analysis.

\section{A.6.2.1 Hand Sampling}

Hand sampling was conducted using disposable scoops to access the surface ( 0 to $1 \mathrm{ft}$ bgs) horizon and collect samples at the seven biased locations presented in the CAIP. Three of these locations (D03, D04, and D05) had subsurface (4 to $5 \mathrm{ft}$ bgs) samples collected using a backhoe. In addition, one background sample (Bkg01) was collected north and outside of the CAS boundary to determine if COCs were present that were not related to this CAS. A total of 11 soil samples were collected at this 


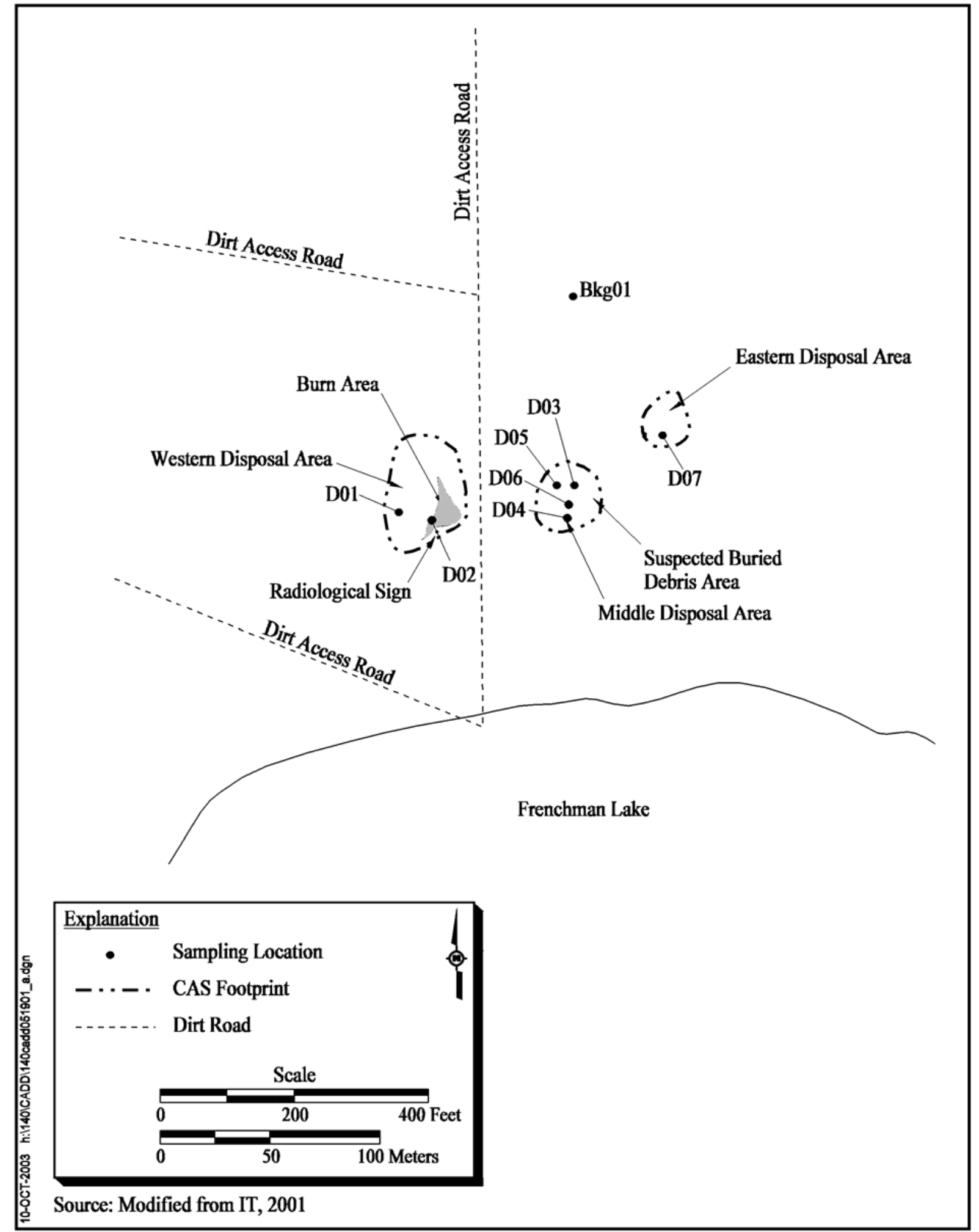

Figure A.6-1

Sampling Locations and Points of Interest at CAS 05-19-01, Waste Disposal Site 
Table A.6-1

Samples Collected at CAS 05-19-01, Waste Disposal Site

\begin{tabular}{|c|c|c|c|c|c|}
\hline $\begin{array}{l}\text { Sample } \\
\text { Number }\end{array}$ & Borehole & $\begin{array}{l}\text { Depth } \\
\text { (ft bgs) }\end{array}$ & $\begin{array}{l}\text { Sample } \\
\text { Matrix }\end{array}$ & Purpose & Analyses \\
\hline 140D001 & D01 & $0-1$ & Soil & SC & Set 4 \\
\hline 140D002 & D02 & $0-1$ & Soil & SC & Set 4 \\
\hline 140D003 & D03 & $0-1$ & Soil & SC & Set 4 \\
\hline 140D004 & D04 & $0-1$ & Soil & SC, Lab QC & Set 4 \\
\hline 140D005 & D05 & $0-1$ & Soil & SC & Set 4 \\
\hline 140D302A & D05 & $0-1$ & Soil & $\begin{array}{c}\text { Field Duplicate } \\
\text { of } 140 D 005\end{array}$ & Set 4 \\
\hline 140D006 & D06 & $0-1$ & Soil & SC & Set 4 \\
\hline 140D007 & D07 & $0-1$ & Soil & SC & Set 4 \\
\hline 140D008 & D03 & $4-5$ & Soil & SC & Set 4 \\
\hline 140D009 & D04 & $4-5$ & Soil & SC & Set 4 \\
\hline 140D010 & D05 & $4-5$ & Soil & SC & Set 4 \\
\hline 140D306 & D05 & $4-5$ & Soil & $\begin{array}{c}\text { Field Duplicate } \\
\text { of } 140 \mathrm{D} 010\end{array}$ & Set 4 \\
\hline 140D011 & BKG01 & $0-1$ & Soil & $\begin{array}{c}\text { SC, } \\
\text { Background }\end{array}$ & $\begin{array}{c}\text { Total Nickel/Zinc, } \\
\text { Total RCRA Metals, Isotopic } \\
\text { Plutonium }\end{array}$ \\
\hline 140D301A & NA & NA & Water & Trip Blank & Total VOCs \\
\hline 140D301 & NA & NA & Water & Source Blank & Set 9 \\
\hline 140D302 & NA & NA & Water & Trip Blank & Total VOCs \\
\hline 140D305 & NA & NA & Water & Trip Blank & Total VOCs \\
\hline
\end{tabular}

Set 4 = Total VOCs, Total SVOCs, PCBs, TPH (DRO and GRO), Nickel, Zinc, Total RCRA Metals, Gamma Spectrometry, Isotopic Plutonium, Isotopic Uranium, and Strontium-90

Set 9 = Total VOCs, Total SVOCs, PCBs, TPH (DRO and GRO), Nickel, Zinc, Total RCRA Metals, Gamma Spectrometry, Isotopic Plutonium, Isotopic Uranium, Strontium-90, Beryllium, Gross Alpha/Beta, Isotopic Technetium, Ethylene Glycol, Antimony, Herbicides, Tritium, Pesticides, and Explosives

$\mathrm{ft}$ bgs $=$ Feet below ground surface

$\mathrm{SC}=$ Site characterization

$\mathrm{QC}=$ Quality control

$\mathrm{NA}=$ Not applicable 
CAS. Samples were not collected at any step-out locations. These soil samples were submitted for laboratory analyses. In addition, one QC source blank and two field duplicates were collected and analyzed.

\section{A.6.2.2 Backhoe Sampling}

A backhoe was used to excavate the subsurface ( 4 to $5 \mathrm{ft}$ bgs) horizon at the Middle Disposal Area at locations D03, D04, and D05 to determine if the geophysical anomaly was actually buried debris and if COPCs were present at depth. The three soil samples were collected by hand from the backhoe bucket using a disposable scoop as described in Section A.2.3.2.

\section{A.6.2.3 Inspection of the Middle Disposal Area}

Excavation with a backhoe was used to explore the subsurface area beneath the removed debris mound in the central area of the CAS. This was based on the results of a surface geophysical survey that indicated the possible presence of buried debris. This survey was performed prior to removal of the surface debris and this may have contributed to the interpretation that subsurface debris was present. An 8-ft deep backhoe excavation was made from location D06 to each of the surrounding sampling locations (D03, D04, and D05). There was no buried debris or soil-staining found beneath the removed debris or beneath these sampling locations. Furthermore, the soil beneath the debris mound did not indicate a previous disturbance; therefore, no additional sampling was conducted beneath the debris mound except for the planned location at D06.

\section{A.6.2.4 Field-Screening Results}

Soil samples were field screened for VOCs and alpha and beta/gamma radiation. The field-screening results were compared to FSLs to guide sampling decisions. The VOC headspace FSLs were not exceeded during excavations or sampling activities. No samples had elevated FSRs for alpha and beta/gamma radiation.

\section{A.6.2.5 Sample Analyses}

The analytical suite for CAS 05-19-01 was specified in the CAIP and included total VOCs, total SVOCs, total RCRA metals plus nickel and zinc, TPH (DRO and GRO), PCBs, isotopic U, isotopic 
$\mathrm{Pu}, \mathrm{Sr}-90$, and gamma-emitting radionuclides. The analytical parameters and laboratory analytical methods used to analyze the investigation samples are listed in Table A.2-1. Table A.6-1 lists the sample-specific analytical parameters.

\section{A.6.2.6 Analytes Detected Above Minimum Reporting Limits}

The analytical results detected at concentrations exceeding the correlated MRLs as established in the CAIP (NNSA/NV, 2002a) are summarized in the following sections. These results were compared to PALs (also established in the CAIP) and are a subset of those that exceed MRLs. All of the analytical results obtained through sample analysis are usable.

\section{A.6.2.6.1 Total Volatile Organic Compound Analytical Results for Soil Samples}

Total VOCs analytical results for soil did not exceed the PALs. Results exceeding MRLs are listed in Table A.6-2.

Table A.6-2

Soil Sample Results for Total VOCs Detected Above Minimum Reporting Limits at CAS 05-19-01

\begin{tabular}{|c|c|c|c||}
\hline \multirow{2}{*}{$\begin{array}{c}\text { Sample } \\
\text { Number }\end{array}$} & \multirow{2}{*}{$\begin{array}{c}\text { Sample } \\
\text { Location }\end{array}$} & $\begin{array}{c}\text { Depth } \\
\text { (ft bgs) }\end{array}$ & Contaminants of Potential Concern $(\mu \mathbf{g} / \mathbf{k g})$ \\
\cline { 3 - 4 } & & & Methylene Chloride \\
\hline \multicolumn{2}{|c|}{ Preliminary Action Levels ${ }^{\mathbf{a}}$} & $\mathbf{2 1 , 0 0 0}$ \\
\hline \hline 140D004 & D04 & $0-1$ & 15 \\
\hline 140D005 & D05 & $0-1$ & 5.6 \\
\hline 140D006 & D06 & $0-1$ & 8.2 \\
\hline
\end{tabular}

aBased on U.S. Environmental Protection Agency, Region 9 Preliminary Remediation Goals (PRGs) (EPA, 2000)

$\mathrm{ft}$ bgs $=$ Feet below ground surface

$\mu \mathrm{g} / \mathrm{kg}=$ Micrograms per kilogram

\section{A.6.2.6.2 Total Semivolatile Organic Compound Analytical Results for Soil Samples}

Total SVOCs analytical results for soil did not exceed the MRLs.

\section{A.6.2.6.3 Total Petroleum Hydrocarbon Analytical Results for Soil Samples}

The TPH (DRO and GRO) analytical results for soil did not exceed the MRLs. 


\section{A.6.2.6.4 Total RCRA Metals Analytical Results for Soil Samples}

Total RCRA metals (plus nickel and zinc) analytical results for soil samples did not exceed the PALs. Results exceeding MRLs are listed in Table A.6-3.

\section{A.6.2.6.5 Polychlorinated Biphenyl Results for Soil Samples}

The PCB analytical results for soil did not exceed the MRLs.

\section{A.6.2.6.6 Gamma Spectrometry Results for Soil Samples}

Gamma spectrometry analytical results for soil that exceed the MRLs are shown in Table A.6-4. Results did not exceed the PALs.

\section{A.6.2.6.7 Isotopic Uranium Results for Soil Samples}

Isotopic uranium analytical results for soil samples detected above MRLs are shown in Table A.6-5. Results, based on the normalized difference test discussed in Section A.2.7, do not exceed the PALs.

\section{A.6.2.6.8 Isotopic Plutonium Results for Soil Samples}

Isotopic plutonium analytical results for soil samples detected above MRLs are shown in Table A.6-5. Locations D03, D04, D05, and D06 have Pu-239 concentrations above PALs; however, since atmospheric testing was conducted in Area 5 the Pu-239 is not considered to be related to CAS 05-19-01 activities; therefore, Pu-239 is not a COC (McArthur and Mead, 1989). Additionally, a background surface soil sample (140D001) was collected north and outside of the CAS 05-19-01 boundary and had a Pu-239 concentration of $4.43 \mathrm{pCi} / \mathrm{g}$.

\section{A.6.2.6.9 Strontium-90 Results for Soil Samples}

Strontium-90 was not detected in soil samples above MRLs.

\section{A.6.2.7 Contaminants of Concern}

Based on the aforementioned analytical results, no COCs were identified in the soil at this CAS. 
Table A.6-3

Soil Sample Results for Total RCRA Metals Detected Above Minimum Reporting Limits at CAS 05-19-01

\begin{tabular}{|c|c|c|c|c|c|c|c|c|c|}
\hline \multirow{2}{*}{$\begin{array}{l}\text { Sample } \\
\text { Number }\end{array}$} & \multirow{2}{*}{$\begin{array}{l}\text { Sample } \\
\text { Location }\end{array}$} & \multirow{2}{*}{$\begin{array}{l}\text { Depth } \\
\text { (ft bgs) }\end{array}$} & \multicolumn{7}{|c|}{ Contaminants of Potential Concern $(\mathrm{mg} / \mathrm{kg})$} \\
\hline & & & Arsenic & Barium & Chromium & Lead & Nickel & Selenium & Zinc \\
\hline \multicolumn{3}{|c|}{ Preliminary Action Levels ${ }^{a}$} & 23 & 100,000 & 450 & 750 & 41,000 & 10,000 & 100,000 \\
\hline 140D001 & D01 & $0-1$ & 5.8 & 190 & 9.4 & 10 & $9.3(J)^{b}$ & -- & $41(J)^{b}$ \\
\hline 140D002 & D02 & $0-1$ & 5.7 & 170 & 10 & 10 & $9.6(J)^{b}$ & $0.66(J)^{c}$ & $43(J)^{b}$ \\
\hline 140D003 & D03 & $0-1$ & 5.5 & 180 & 9.7 & 11 & $9.8(J)^{b}$ & $0.56(\mathrm{~J})^{\mathrm{c}}$ & $68(J)^{b}$ \\
\hline 140D004 & D04 & $0-1$ & 6.4 & 190 & 12 & 13 & $12(\mathrm{~J})^{\mathrm{b}}$ & -- & $54(\mathrm{~J})^{\mathrm{b}}$ \\
\hline 140D005 & D05 & $0-1$ & 5.3 & 170 & 9.1 & 9.8 & $9.2(\mathrm{~J})^{\mathrm{b}}$ & -- & $49(\mathrm{~J})^{\mathrm{b}}$ \\
\hline 140D006 & D06 & $0-1$ & 5.4 & 180 & 10 & 18 & $9.8(J)^{b}$ & $0.75(\mathrm{~J})^{\mathrm{c}}$ & $50(J)^{b}$ \\
\hline 140D007 & D07 & $0-1$ & 6 & 180 & 9.5 & 9.9 & $9.9(J)^{b}$ & -- & 42 \\
\hline 140D008 & D03 & $4-5$ & 5.3 & 240 & 7.6 & 11 & 8.8 & -- & 35 \\
\hline 140D009 & D04 & $4-5$ & 5.9 & 200 & 7.1 & 10 & 8.2 & -- & 34 \\
\hline 140D010 & D05 & $4-5$ & 5 & 180 & 6.1 & 9 & 7.4 & -- & 30 \\
\hline 140D011 & BKG01 & $0-1$ & 5 & 160 & 8.4 & 81 & 8.4 & -- & 39 \\
\hline $\begin{array}{c}\text { 140D302 } \\
A\end{array}$ & D05 & $0-1$ & 5.2 & 170 & 8.7 & 9.6 & $8.8(J)^{b}$ & $0.65(\mathrm{~J})^{\mathrm{c}}$ & $48(J)^{b}$ \\
\hline 140D306 & & $4-5$ & 4.7 & 210 & 6 & 8.9 & 7.2 & -- & 30 \\
\hline
\end{tabular}

aBased on U.S. Environmental Protection Agency, Region 9 Preliminary Remediation Goals (PRGs) (EPA, 2000). The PAL for arsenic is the mean plus two times the standard deviation of the mean for sediment samples collected by the NBMG throughout NTTR (NBMG, 1998; Moore, 1999)

${ }^{b}$ Qualifier added to laboratory data; record accepted. Serial dilution \%D outside of control limits. Matrix effects may exist.

${ }^{\circ}$ Qualifier added to laboratory data; record accepted. Negative bias found in continuing calibration/method blank.

$\mathrm{ft}$ bgs = Feet below ground surface

$\mathrm{mg} / \mathrm{kg}=$ Milligrams per kilogram

-- = Not detected above minimum reporting limit

$\mathrm{J}=$ Estimated value 
Table A.6-4

Soil Sample Results for Gamma-Emitting Radionuclides Detected Above Minimum Reporting Limits at CAS 05-19-01

\begin{tabular}{|c|c|c|c|c|c|c|c|c|c|}
\hline \multirow{2}{*}{$\begin{array}{l}\text { Sample } \\
\text { Number }\end{array}$} & \multirow{2}{*}{$\begin{array}{l}\text { Sample } \\
\text { Location }\end{array}$} & \multirow{2}{*}{$\begin{array}{c}\text { Depth } \\
\text { (ft bgs) }\end{array}$} & \multicolumn{7}{|c|}{ Contaminants of Potential Concern (pCi/g) } \\
\hline & & & Actinium-228 & Bismuth-214 & Cesium-137 & Lead-212 & Lead-214 & Potassium-40 & Thallium-208 \\
\hline \multicolumn{3}{|c|}{ Preliminary Action Levels } & $3.64^{\mathrm{a}}$ & $3.47^{\mathrm{a}}$ & $7.033^{b}$ & $3.64^{\mathrm{a}}$ & $3.47^{\mathrm{a}}$ & $97.7^{\mathrm{a}}$ & $3.38^{\mathrm{a}}$ \\
\hline $140 \mathrm{D001}$ & $\overline{\mathrm{D} 01}$ & $0-1$ & $1.54 \pm 0.35$ & $0.77 \pm 0.20$ & -- & $1.63 \pm 0.31$ & $1.04 \pm 0.22$ & $23.3 \pm 4.2$ & $0.45 \pm 0.11$ \\
\hline 140D002 & D02 & $0-1$ & $1.35 \pm 0.38$ & $0.84 \pm 0.25$ & $\overline{--}$ & $1.25 \pm 0.28$ & $0.82 \pm 0.22$ & $24 \pm 4.9$ & $0.44 \pm 0.13$ \\
\hline $140 \mathrm{D003}$ & D03 & $0-1$ & $1.17 \pm 0.37$ & $0.89 \pm 0.28$ & -- & $1.42 \pm 0.32$ & $1.04 \pm 0.25$ & $24.2 \pm 4.9$ & $0.62 \pm 0.17$ \\
\hline 140D004 & D04 & $0-1$ & $1.48 \pm 0.32$ & $0.8 \pm 0.20$ & $\begin{array}{ll}- \\
-\end{array}$ & $1.63 \pm 0.30$ & $0.96 \pm 0.20$ & $23 \pm 4.1$ & $0.48 \pm 0.11$ \\
\hline 140D005 & D05 & $0-1$ & $1.43 \pm 0.39$ & $0.75 \pm 0.23$ & -- & $1.47 \pm 0.31$ & $1.05 \pm 0.24$ & $20.3 \pm 4.1$ & $0.42 \pm 0.13$ \\
\hline 140D006 & D06 & $0-1$ & $1.26 \pm 0.36$ & $0.91 \pm 0.27$ & $0.32 \pm 0.12$ & $1.54 \pm 0.33$ & $0.71 \pm 0.21$ & $22 \pm 4.6$ & $0.42 \pm 0.13$ \\
\hline 140D007 & D07 & $0-1$ & $1.48 \pm 0.43$ & $1.12 \pm 0.33$ & $\begin{array}{l}- \\
-\end{array}$ & $1.46 \pm 0.32$ & $0.94 \pm 0.24$ & $20.9 \pm 4.4$ & $0.42 \pm 0.14$ \\
\hline 140D008 & D03 & $4-5$ & $1.59 \pm 0.33$ & $0.98 \pm 0.22$ & -- & $1.78 \pm 0.33$ & $1.14 \pm 0.23$ & $25 \pm 4.4$ & $0.53 \pm 0.12$ \\
\hline 140D009 & D04 & $4-5$ & $1.54 \pm 0.38$ & $1.01 \pm 0.25$ & -- & $1.98 \pm 0.38$ & $0.99 \pm 0.22$ & $24.5 \pm 4.7$ & $0.52 \pm 0.14$ \\
\hline 140D010 & \multirow{3}{*}{ D05 } & $4-5$ & $1.33 \pm 0.40$ & $1.04 \pm 0.32$ & -- & $1.83 \pm 0.37$ & $1.02 \pm 0.26$ & $24 \pm 5.0$ & $0.51 \pm 0.15$ \\
\hline 140D302A & & $0-1$ & $1.52 \pm 0.40$ & $0.68 \pm 0.22$ & -- & $1.28 \pm 0.28$ & $0.9 \pm 0.22$ & $20.4 \pm 4.2$ & $0.48 \pm 0.13$ \\
\hline 140D306 & & $4-5$ & $1.83 \pm 0.38$ & $1.09 \pm 0.24$ & -- & $1.8 \pm 0.33$ & $1.13 \pm 0.23$ & $25.1 \pm 4.5$ & $0.48 \pm 0.11$ \\
\hline
\end{tabular}

aBased on background concentration listed in Environmental Monitoring Report for the Proposed Ward Valley, California, Low-Level Radioactive Waste (LLRW) Facility (US Ecology and Atlan-Tech, 1992)

Based on background concentration listed or derived in Off-Site Radiation Exposure Review Project, Phase /l Soil Program (McArthur and Miller, 1989).

$\mathrm{ft}$ bgs $=$ Feet below ground surface

$\mathrm{pCi} / \mathrm{g}=$ Picocuries per gram

-- = Not detected above minimum reporting limits 
Table A.6-5

Soil Sample Results for Isotopes Detected Above Minimum Reporting Limits at CAS 05-19-01

\begin{tabular}{|c|c|c|c|c|c|c|c|}
\hline \multirow{2}{*}{$\begin{array}{l}\text { Sample } \\
\text { Number }\end{array}$} & \multirow{2}{*}{$\begin{array}{c}\text { Sample } \\
\text { Location }\end{array}$} & \multirow{2}{*}{$\begin{array}{l}\text { Depth } \\
\text { (ft bgs) }\end{array}$} & \multicolumn{5}{|c|}{ Contaminants of Potential Concern (pCi/g) } \\
\hline & & & Uranium-234 & Uranium-235 & Uranium-238 ${ }^{\text {b }}$ & Plutonium-238 ${ }^{\mathrm{b}}$ & Plutonium-239 \\
\hline$\overline{140 D 001}$ & $\overline{\mathrm{D} 01}$ & $0-1$ & $0.89 \pm 0.17$ & $\overline{--}$ & $0.87 \pm 0.17$ & $\overline{---}$ & $0.104 \pm 0.039$ \\
\hline 140D004 & D04 & $0-1$ & $1.09 \pm 0.21$ & -- & $0.98 \pm 0.19$ & -- & $0.283 \pm 0.076^{d}$ \\
\hline 140D005 & D05 & $0-1$ & $0.9 \pm 0.17$ & - & $0.82 \pm 0.15$ & -- & $0.273 \pm 0.070^{\mathrm{d}}$ \\
\hline 140D006 & D06 & $0-1$ & $0.74 \pm 0.14$ & -- & $0.82 \pm 0.15$ & -- & $1.02 \pm 0.18^{\mathrm{d}}$ \\
\hline $140 D 010$ & D05 & $4-5$ & $0.95 \pm 0.18$ & $0.058 \pm 0.034$ & $0.92 \pm 0.18$ & $\overline{--}$ & $\overline{--}$ \\
\hline 140D011 & BGK01 & $0-1$ & -- & -- & $\overline{--}$ & $0.065 \pm 0.030^{d}$ & $4.43 \pm 0.66^{d}$ \\
\hline 140D302A & ח & $0-1$ & $0.74 \pm 0.16(\mathrm{~J})$ & -- & $0.79 \pm 0.17(\mathrm{~J})$ & -- & $0.226 \pm 0.061^{d}$ \\
\hline 140D306 & DUJ & $4-5$ & $1.11 \pm 0.20$ & $0.073 \pm 0.037^{c}$ & $1.05 \pm 0.19$ & - & 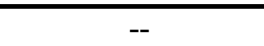 \\
\hline
\end{tabular}

aBased on background concentration listed in Environmental Monitoring Report for the Proposed Ward Valley, California, Low-Level Radioactive Waste (LLRW) Facility (US Ecology and Atlan-Tech, 1992)

${ }^{\text {b} B a s e d ~ o n ~ b a c k g r o u n d ~ c o n c e n t r a t i o n ~ l i s t e d ~ o r ~ d e r i v e d ~ i n ~ O f f-S i t e ~ R a d i a t i o n ~ E x p o s u r e ~ R e v i e w ~ P r o j e c t, ~ P h a s e ~ / I ~ S o i l ~ P r o g r a m ~(M c A r t h u r ~ a n d ~}$ Miller, 1989)

'Based on the normalized difference test, these results are considered to be less than PALs.

${ }^{\mathrm{d}}$ Not considered to be related to CAS activities

$\mathrm{ft}$ bgs $=$ Feet below ground surface

$\mathrm{pCi} / \mathrm{g}=$ Picocuries per gram

$--=$ Not detected above minimum reporting limits

$\mathrm{J}=$ Estimated value. Qualifier added to laboratory data; record accepted. Chemical yield below control limits.

\section{A.6.3 Nature and Extent of COCs}

No COCs were identified in the soil at this CAS.

\section{A.6.4 Revised Conceptual Site Model}

No variations to the CSM were identified. 


\section{A.7.0 Gravel Gertie (CAS 05-23-01)}

Corrective Action Site 05-23-01 (Figure A.7-1) is located approximately $2.1 \mathrm{mi}$ north of the Mercury Highway and 5-01 intersection on the west side of 5-01 Road. The site is relatively flat except for the Gravel Gertie structure, a dirt mound southeast of the door, a nearby dirt mound, and a borrow pit. The dirt mound had been connected to the Gravel Gertie as a ramp to the top, and was previously cut through to limit access to the top. Scattered debris includes cable, wood scraps, wire, rebar, a mounted electrical box, sandbags around the entrance, and metal mesh on the sides and top of the structure. The sides of the Gravel Gertie are steep with angles generally ranging between 60 and 70 degrees. There are large cable towers/telephone poles and associated guywires. Vegetation in the area is sparse, with some vegetation on the Gravel Gertie.

The Gravel Gertie was designed in 1956 by the U.S. Atomic Energy Commission and built by Sandia National Laboratories (SNL). The structure was used by SNL for three tests in 1957 to test the ability to minimize contamination in the event of an accidental explosion associated with chemical explosives and nuclear material. The three tests involved high explosives (HE) and uranium was used as a tracer material in the last two tests (Sandia Corporation, 1964). The structure was also used for similar testing in 1982, which involved HE, depleted uranium, and antimony oxide (Metcalf, 2002).

\section{A.7.1 Corrective Action Investigation}

Five soil samples and associated QC samples were collected during investigation activities at this CAS and are listed in Table A.7-1. The actual sample locations correspond with the planned sample locations identified in the CAIP and are shown in Figure A.7-1. The specific CAI activities conducted to meet CAIP requirements are described in the following sections.

\section{A.7.1.1 Deviations}

There were no deviations to the CAIP requirements.

\section{A.7.2 Investigation Results}

The following sections provide CAS-specific details of the sampling, FSRs, and sample selection and analysis. 


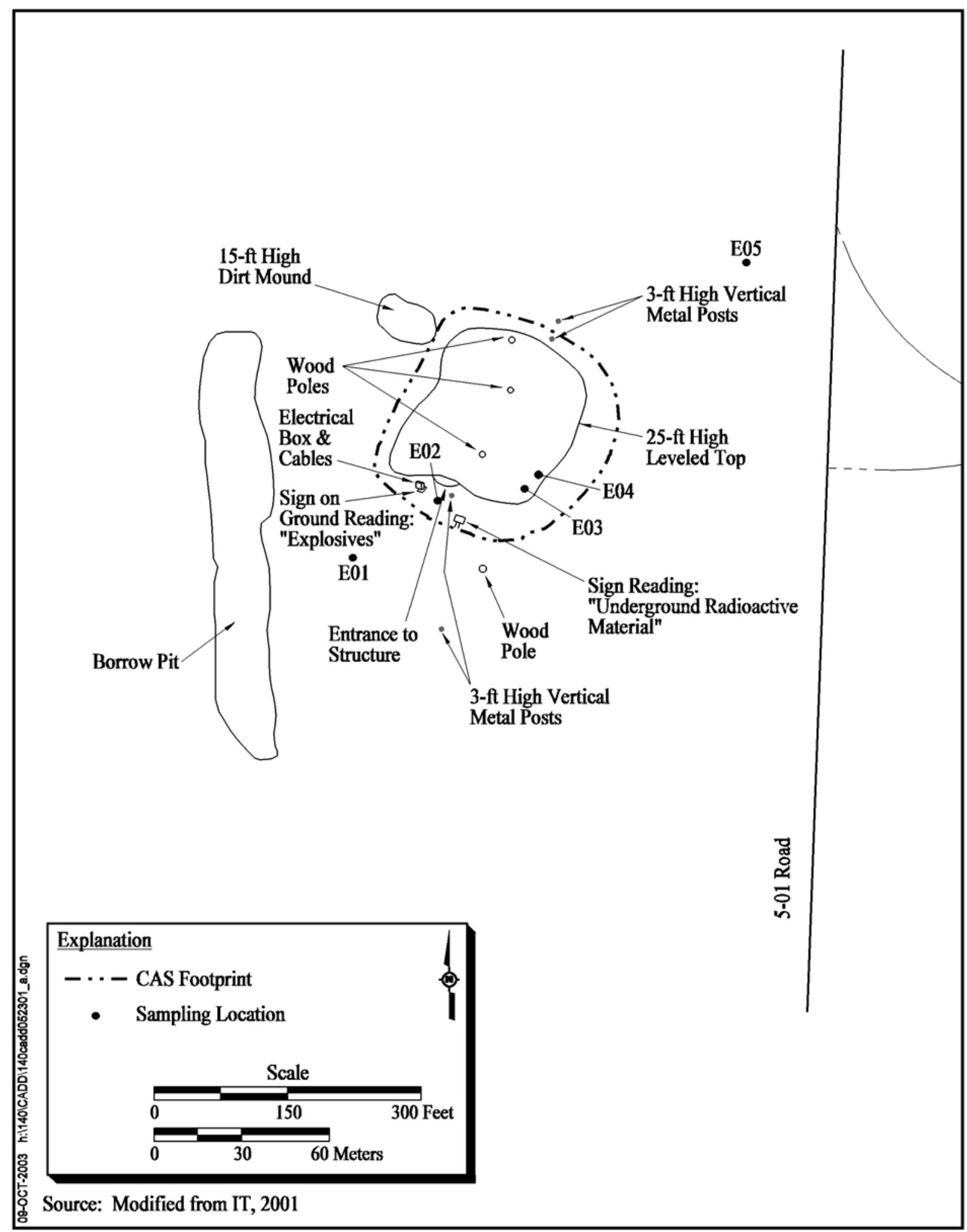

Figure A.7-1

Sampling Locations and Points of Interest at CAS 05-23-01, Gravel Gertie 
Table A.7-1

Samples Collected at CAS 05-23-01, Gravel Gertie

\begin{tabular}{||c|c|c|c|c|c||}
\hline $\begin{array}{c}\text { Sample } \\
\text { Number }\end{array}$ & Borehole & $\begin{array}{c}\text { Depth } \\
\text { (ft bgs) }\end{array}$ & $\begin{array}{c}\text { Sample } \\
\text { Matrix }\end{array}$ & Purpose & Analyses \\
\hline \hline $140 \mathrm{E} 001$ & $\mathrm{E} 01$ & $0-1$ & Soil & SC & Set 5 \\
\hline $140 \mathrm{E} 002$ & $\mathrm{E} 02$ & $0-1$ & Soil & SC & Set 5 \\
\hline $140 \mathrm{E} 003$ & $\mathrm{E} 03$ & $0-1$ & Soil & SC & Set 5 \\
\hline $140 \mathrm{E} 004$ & $\mathrm{E} 04$ & $0-1$ & Soil & SC & Set 5 \\
\hline $140 \mathrm{E} 005$ & $\mathrm{E} 05$ & $0-1$ & Soil & SC & Set 5 \\
\hline
\end{tabular}

Set 5 = Explosives, PCBs, Antimony, Gamma Spectrometry, Isotopic Plutonium, Isotopic Uranium, and Strontium-90

$\mathrm{ft}$ bgs $=$ Feet below ground surface $\mathrm{SC}=$ Site characterization

\section{A.7.2.1 Hand Sampling}

A surface radiological survey (Alderson, 2002) was used to select biased surface soil sample locations on top of and around the Gravel Gertie. Hand sampling was conducted using disposable scoops to collect these surface ( 0 to $1 \mathrm{ft}$ bgs) samples at the five biased locations presented in the CAIP. A total of five soil samples were collected at this CAS. Samples were not collected at any step-out locations or subsurface. All soil samples were submitted for laboratory analyses.

\section{A.7.2.2 Field-Screening Results}

Soil samples were field screened for VOCs and alpha and beta/gamma radiation. The FSRs were compared to FSLs to guide sampling decisions. The VOC headspace and radiological FSLs were not exceeded during sampling activities.

\section{A.7.2.3 Sample Analyses}

Investigation soil samples were analyzed for CAIP-specified COPCs which included total antimony, explosives, $\mathrm{PCBs}$, isotopic $\mathrm{U}$, isotopic $\mathrm{Pu}, \mathrm{Sr}-90$, and gamma-emitting radionuclides. The analytical parameters and laboratory methods used to analyze the investigation samples are listed in Table A.2-1. Table A.7-1 lists the sample-specific analytical parameters. 


\section{A.7.2.4 Analytes Detected Above Minimum Reporting Limits}

The analytical results detected at concentrations exceeding the correlated MRLs as established in the CAIP (NNSA/NV, 2002a) are summarized in the following sections. These results are compared to PALs (also established in the CAIP) that are a subset of those that exceed MRLs. All of the analytical results obtained through sample analysis are usable.

\section{A.7.2.4.1 Antimony Analytical Results for Soil Samples}

The metal antimony was not detected in soil samples at concentrations exceeding MRLs.

\section{A.7.2.4.2 Polychlorinated Biphenyl Results for Soil Samples}

No PCB analytical results for soil exceeded the MRLs.

\section{A.7.2.5 Explosives}

No explosives analytical results for soil exceeded the MRLs.

\section{A.7.2.5.1 Gamma Spectrometry Results for Soil Samples}

Gamma spectrometry analytical results for detected radionuclide concentrations exceeding the MRLs are shown in Table A.7-2. None of the results exceed the PALs.

\section{A.7.2.5.2 Isotopic Uranium Results for Soil Samples}

Isotopic uranium results were detected in soil samples above MRLs and are presented in Table A.7-3. The results, based on the normalized difference test, do not exceed the PALs. Although, uranium was not detected above the PALs during sampling activities, uranium is an expected contaminant inside the Gravel Gertie since it was used as a tracer in the Gravel Gertie experiments.

\section{A.7.2.5.3 Isotopic Plutonium Results for Soil Samples}

Isotopic Pu-239 was detected in soil samples above MRLs. Results are presented in Table A.7-3. Results did not exceed the PALs. 
Table A.7-2

Soil Sample Results for Gamma-Emitting Radionuclides

Detected Above Minimum Reporting Limits at CAS 05-23-01

\begin{tabular}{|c|c|c|c|c|c|c|c|c|}
\hline \multirow{2}{*}{$\begin{array}{l}\text { Sample } \\
\text { Number }\end{array}$} & \multirow{2}{*}{$\begin{array}{l}\text { Sample } \\
\text { Location }\end{array}$} & \multirow{2}{*}{$\begin{array}{l}\text { Depth } \\
\text { (ft bgs) }\end{array}$} & \multicolumn{6}{|c|}{ Contaminants of Potential Concern (pCi/g) } \\
\hline & & & Actinium-228 & Bismuth-214 & Lead-212 & Lead-214 & Potassium-40 & Thallium-208 \\
\hline \multicolumn{3}{|c|}{ Preliminary Action Levels ${ }^{a}$} & 3.64 & 3.47 & 3.64 & 3.47 & 97.7 & 3.38 \\
\hline 14 140E001 & $\bar{E}$ E01 & $\overline{0-1}$ & $0.96 \pm 0.31$ & $0.94 \pm 0.28$ & $1.18 \pm 0.28$ & $0.87 \pm 0.22$ & $15.2 \pm 3.4$ & $0.29 \pm 0.12$ \\
\hline 140E002 & $\overline{E 02}$ & $0-1$ & $0.58 \pm 0.23$ & $0.45 \pm 0.16$ & $0.49 \pm 0.14$ & $0.51 \pm 0.14$ & $11.6 \pm 2.5$ & $0.208 \pm 0.076$ \\
\hline 140E003 & E03 & $0-1$ & $1.29 \pm 0.36$ & $0.82 \pm 0.25$ & $1.43 \pm 0.30$ & $0.79 \pm 0.21$ & $15.2 \pm 3.5$ & $0.4 \pm 0.13$ \\
\hline 140E004 & E04 & $0-1$ & $0.83 \pm 0.30$ & $0.71 \pm 0.21$ & $1.02 \pm 0.23$ & $0.56 \pm 0.16$ & $10.8 \pm 2.5$ & $0.35 \pm 0.11$ \\
\hline 140E005 & E05 & $0-1$ & $0.63 \pm 0.23$ & $0.82 \pm 0.22$ & $0.99 \pm 0.22$ & $0.72 \pm 0.18$ & $13.1 \pm 2.8$ & $0.293 \pm 0.093$ \\
\hline
\end{tabular}

aased on background concentration listed in Environmental Monitoring Report for the Proposed Ward Valley, California, Low-Level Radioactive Waste (LLRW) Facility (US Ecology and Atlan-Tech, 1992)

$\mathrm{ft}$ bgs $=$ Feet below ground surface

$\mathrm{pCi} / \mathrm{g}=$ Picocuries per gram

Table A.7-3

Soil Sample Results for Isotopes Detected Above Minimum Reporting Limits at CAS 05-23-01

\begin{tabular}{|c|c|c|c|c|c|c|}
\hline \multirow{2}{*}{$\begin{array}{l}\text { Sample } \\
\text { Number }\end{array}$} & \multirow{2}{*}{$\begin{array}{c}\text { Sample } \\
\text { Location }\end{array}$} & \multirow{2}{*}{$\begin{array}{l}\text { Depth } \\
\text { (ft bgs) }\end{array}$} & \multicolumn{4}{|c|}{ Contaminants of Potential Concern (pCi/g) } \\
\hline & & & Plutonium-239 & Uranium-234 ${ }^{\mathrm{a}}$ & Uranium-235 & Uranium-238 \\
\hline \multicolumn{3}{|c|}{ Preliminary Action Levels } & 0.106 & 3.47 & 0.07 & 3.47 \\
\hline 140E001 & $\overline{E 01}$ & $0-1$ & -- & $1.04 \pm 0.19$ & -- & $1.11 \pm 0.20$ \\
\hline 140E002 & E02 & $0-1$ & $0.051 \pm 0.027$ & $0.65 \pm 0.12$ & $0.067 \pm 0.034$ & $1.19 \pm 0.20$ \\
\hline 140E003 & E03 & $0-1$ & -- & $1.3 \pm 0.22$ & $0.186 \pm 0.064$ & $1.65 \pm 0.27$ \\
\hline 140E004 & E04 & $0-1$ & -- & $1.03 \pm 0.18$ & -- & $1.47 \pm 0.23$ \\
\hline 140E005 & E05 & $0-1$ & -- & $0.58 \pm 0.12$ & -- & $0.47 \pm 0.11$ \\
\hline
\end{tabular}

'Based on background concentration listed in Environmental Monitoring Report for the Proposed Ward Valley, California, Low-Level Radioactive Waste (LLRW) Facility (US Ecology and Atlan-Tech, 1992)

${ }^{\mathrm{b}}$ Based on background concentration listed or derived in Off-Site Radiation Exposure Review Project, Phase II Soil Program (McArthur and Miller, 1989).

$\mathrm{ft}$ bgs $=$ Feet below ground surface $\mathrm{pCi} / \mathrm{g}=$ Picocuries per gram

-- = Not detected above minimum reporting limits 


\section{A.7.2.5.4 Strontium-90 Results for Soil Samples}

Strontium-90 was not detected in soil samples above MRLs.

\section{A.7.2.6 Contaminants of Concern}

Based on the aforementioned analytical results, no COCs were identified in the soil at this CAS.

\section{A.7.3 Nature and Extent of Contaminants of Concern}

No COCs were identified in the soil at this CAS. Due to the physical constraints of the structure, it is not practical to collect samples from inside the Gravel Gertie. Historical radiological surveys using "sticky trays" and air monitoring of the Gravel Gertie experiments that have used uranium as a tracer material have not identified significant levels of external (to the structure) contamination. The only identified external contamination occurred during test Number 2 in 1957, and was due to venting through the open portal of the structure. For test Numbers 2 and 3, the total estimated amount of uranium that escaped the confines of the structure based on measurements of uranium deposited on “sticky trays" was 2.5 percent (0.8 kilograms) (Sandia Corporation, 1964). Based on the historical documentation, the Gravel Gertie internal structure is considered to be contaminated.

\section{A.7.4 Revised Conceptual Site Model}

No variations to the CSM were identified. 


\section{A.8.0 Burn Pit (CAS 05-35-01)}

Corrective Action Site 05-35-01 (Figure A.8-1) is located just south of the Area 5 RWMS. This CAS consists of a 400 - by 250 -ft covered burn pit area, which is partially surrounded by a 1 -ft high berm. The burn pit area appears to have been covered with native soil, and a dirt road cuts through the west half of the site. A 1-ft high berm is believed to be the eastern boundary of the site. Small pieces of charcoal are scattered on the ground surface throughout the site, and two burn stains are visible on the dirt road. A geophysical survey did not identify buried debris. Vegetation, which is less dense than the surrounding landscape, covers the site.

\section{A.8.1 Corrective Action Investigation}

Eight soil samples and associated QC samples were collected during investigation activities at this CAS and are listed in Table A.8-1. The actual sample locations correspond with the planned sample locations identified in the CAIP and are shown in Figure A.8-1. The specific CAI activities conducted to meet CAIP requirements are described in the following sections.

\section{A.8.1.1 Deviations}

There were no deviations from the CAIP requirements.

\section{A.8.2 Investigation Results}

The following sections provide CAS-specific details of the soil sampling, FSRs, and sample selection and analysis.

\section{A.8.2.1 Soil Sampling}

Eight surface and subsurface soil samples ( 0 to $1 \mathrm{ft}$ and 3 to $4 \mathrm{ft} \mathrm{bgs}$ ) were collected at four locations. During sample collection at locations F01 and F02, a dark staining was observed from 0 to $0.5 \mathrm{ft}$ bgs. Deeper samples were collected at these locations and no staining was present. All samples were sent to the laboratory for analysis. See Table A.8-1 and Figure A.8-1 for sample locations and depths. Samples were collected using a scoop for surface samples and a power auger was used to access subsurface sample horizons, then a scoop was used for collection. 


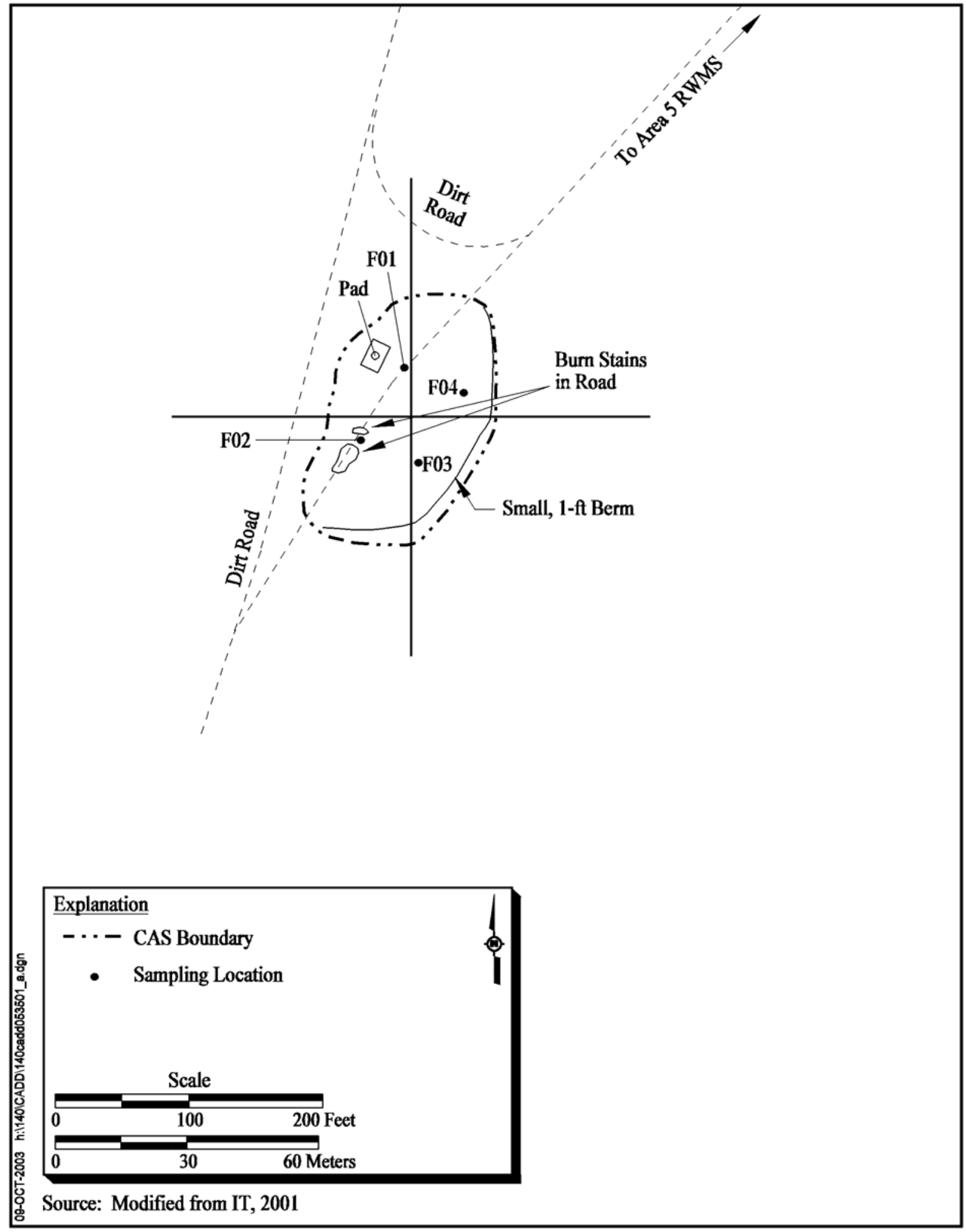

Figure A.8-1

Sampling Locations and Points of Interest at CAS 05-35-01, Burn Pit 
Table A.8-1

Samples Collected at CAS 05-35-01, Burn Pit

\begin{tabular}{|c|c|c|c|c|c|}
\hline $\begin{array}{c}\text { Sample } \\
\text { Number }\end{array}$ & Borehole & $\begin{array}{c}\text { Depth } \\
\text { (ft bgs) }\end{array}$ & $\begin{array}{c}\text { Sample } \\
\text { Matrix }\end{array}$ & Purpose & Analyses \\
\hline \hline $140 F 001$ & F01 & $0-1$ & Soil & SC & Set 6 \\
\hline $140 F 002$ & F02 & $0-1$ & Soil & SC & Set 6 \\
\hline $140 F 003$ & F03 & $0-1$ & Soil & SC & Set 6 \\
\hline $140 F 004$ & F04 & $0-1$ & Soil & SC & Set 6 \\
\hline $140 F 005$ & F01 & $3-4$ & Soil & SC & Set 6 \\
\hline $140 F 006$ & F02 & $3-4$ & Soil & SC & Set 6 \\
\hline $140 F 007$ & F03 & $3-4$ & Soil & SC & Set 6 \\
\hline $140 F 008$ & F04 & $3-4$ & Soil & Trip Blank & Total VOCs \\
\hline $140 F 301$ & NA & NA & Water & & SC \\
\hline
\end{tabular}

Set 6 = Total VOCs, Total SVOCs, TPH (DRO and GRO), PCBs, Nickel, Zinc, and Total RCRA Metals

$\mathrm{ft}$ bgs $=$ Feet below ground surface

$\mathrm{SC}=$ Site characterization

NA $=$ Not applicable

\section{A.8.2.2 Field-Screening Results}

Soil samples were field screened for VOCs and alpha and beta/gamma radiation. The FSRs were compared to FSLs to guide sampling decisions. The VOC headspace FSLs were not exceeded during sampling activities. Soil samples did not exceed FSLs for alpha and beta/gamma radiation.

\section{A.8.2.3 Sample Analyses}

Investigation soil samples were analyzed for CAIP-specified COPCs including total VOCs, total SVOCs, total RCRA metals plus nickel and zinc, TPH (DRO and GRO), and PCBs. The analytical parameters and laboratory analytical methods used to analyze the investigation samples are listed in Table A.2-1. Table A.8-1 lists the sample-specific analytical parameters.

\section{A.8.2.4 Analytes Detected Above Minimum Reporting Limits}

The analytical results detected at concentrations exceeding the MRLs as established in the CAIP (NNSA/NV, 2002a) are summarized in the following sections. These results have been compared to PALs (also established in the CAIP) that are a subset of those that exceed MRLs. A portion of the 
analytical results were rejected; however, these rejected data did not adversely impact closure decisions as discussed in Appendix B, Section B.1.1.4.

\section{A.8.2.4.1 Total Volatile Organic Compound Analytical Results for Soil Samples}

Total VOCs analytical results for soil samples exceeding the MRLs are shown in Table A.8-2. These results did not exceed the PALs.

Table A.8-2

Soil Sample Results for Total VOCs Detected Above Minimum Reporting Limits at CAS 05-35-01

\begin{tabular}{|c|c|c|c|}
\hline \multirow{2}{*}{$\begin{array}{l}\text { Sample } \\
\text { Number }\end{array}$} & \multirow{2}{*}{$\begin{array}{l}\text { Sample } \\
\text { Location }\end{array}$} & \multirow{2}{*}{$\begin{array}{l}\text { Depth } \\
\text { (ft bgs) }\end{array}$} & Contaminants of Potential Concern $(\mu \mathrm{g} / \mathrm{kg})$ \\
\hline & & & Methylene Chloride \\
\hline \multicolumn{3}{|c|}{ Preliminary Action Levels ${ }^{a}$} & 21,000 \\
\hline 140F004 & $\overline{\text { F04 }}$ & $\overline{0-1}$ & $\overline{333}$ \\
\hline 140F005 & F01 & $3-4$ & 25 \\
\hline
\end{tabular}

${ }^{a}$ Based on U.S. Environmental Protection Agency, Region 9 Preliminary Remediation Goals (PRGs) (EPA, 2000)

$\mathrm{ft}$ bgs $=$ Feet below ground surface

$\mu \mathrm{g} / \mathrm{kg}=$ Micrograms per kilogram

\section{A.8.2.4.2 Total Semivolatile Organic Compound Analytical Results for Soil Samples}

No total SVOCs analytical results for soil exceeded the MRLs.

\section{A.8.2.4.3 Total Petroleum Hydrocarbon Analytical Results for Soil Samples}

No TPH analytical results for soil exceeded the MRLs.

\section{A.8.2.4.4 Total RCRA Metals Analytical Results for Soil Samples}

Total RCRA metals plus nickel and zinc analytical results for soil samples did not exceed the PALs. Results exceeding MRLs are listed in Table A.8-3.

\section{A.8.2.4.5 Polychlorinated Biphenyl Results for Soil Samples}

No PCB analytical results for soil exceeded the MRLs. 
Table A.8-3

Soil Sample Results for Total RCRA Metals Detected Above Minimum Reporting Limits at CAS 05-35-01

\begin{tabular}{|c|c|c|c|c|c|c|c|c|c|}
\hline \multirow{2}{*}{$\begin{array}{l}\text { Sample } \\
\text { Number }\end{array}$} & \multirow{2}{*}{$\begin{array}{c}\text { Sample } \\
\text { Location }\end{array}$} & \multirow{2}{*}{$\begin{array}{l}\text { Depth } \\
\text { (ft bgs) }\end{array}$} & \multicolumn{7}{|c|}{ Contaminants of Potential Concern (mg/kg) } \\
\hline & & & Arsenic & Barium & Chromium & Lead & Nickel & Selenium & Zinc \\
\hline \multicolumn{3}{|c|}{ Preliminary Action Levels ${ }^{a}$} & 23 & 100,000 & 450 & 750 & 41,000 & 10,000 & 100,000 \\
\hline$\overline{140 F 001}$ & F01 & $0-1$ & $\overline{11}$ & 170 & 55 & 55 & $\overline{14}$ & $\overline{1}$ & $\overline{1,700(\mathrm{~J})}$ \\
\hline 140F002 & F02 & $0-1$ & 4.6 & 110 & 9.4 & 31 & 7.1 & -- & $140(\mathrm{~J})$ \\
\hline 140F003 & F03 & $0-1$ & 3.5 & 120 & 5.1 & 8.9 & 4.9 & 0.51 & $26(\mathrm{~J})$ \\
\hline 140F004 & F04 & $0-1$ & 3.6 & 120 & 4.8 & 8.7 & 4.8 & 6 & $25(\mathrm{~J})$ \\
\hline 140F005 & F01 & $3-4$ & 7.3 & 140 & 18 & 11 & 8.9 & 0.57 & $390(\mathrm{~J})$ \\
\hline 140F006 & F02 & $3-4$ & 3.5 & 140 & 4.9 & 8.6 & 4.8 & -- & $28(\mathrm{~J})$ \\
\hline 140F007 & F03 & $3-4$ & 3 & 100 & 4.1 & 6.9 & 4.3 & -- & $20(\mathrm{~J})$ \\
\hline 140F008 & F04 & $3-4$ & 3.5 & 110 & 4.8 & 7.9 & 5 & -- & $23(\mathrm{~J})$ \\
\hline
\end{tabular}

aBased on U.S. Environmental Protection Agency, Region 9 Preliminary Remediation Goals (PRGs) (EPA, 2000). Arsenic is the mean plus two times the standard deviation of the mean for sediment samples collected by the NBMG throughout NTTR (NBMG, 1998; Moore, 1999)

$\mathrm{ft}$ bgs $=$ Feet below ground surface

$\mathrm{mg} / \mathrm{kg}=$ Milligrams per kilogram

-- = Not detected above minimum reporting limit

$\mathrm{J}=$ Estimated value. Qualifier added to laboratory data; record accepted. Matrix spike recovery outside of control limits.

\section{A.8.2.5 Contaminants of Concern}

Based on the aforementioned analytical results, no COCs were identified in the soil at this CAS.

\section{A.8.3 Nature and Extent of Contaminants of Concern}

No COCs were identified in the soil at this CAS.

\section{A.8.4 Revised Conceptual Site Model}

No variations to the CSM were identified. 


\section{A.9.0 Burn Pit (CAS 05-99-04)}

Corrective Action Site 05-99-04 (Figure A.9-1) is located west and north of the Hazardous Material Spill Support Facility. The site includes three burn areas. The term "pit" is misleading as the burning appears to have been surface burning. Surface debris includes burned tires, metal debris, wires, broken glass, and concrete piles. The ground surface and the vegetation are otherwise relatively undisturbed.

\section{A.9.1 Corrective Action Investigation}

Three investigation samples and associated QC samples were collected during investigation activities at this CAS and are listed in Table A.9-1. The actual sample locations correspond with the planned sample locations identified in the CAIP and are shown in Figure A.9-1. The specific CAI activities conducted to meet CAIP requirements are described in the following sections.

\section{A.9.1.1 Deviations}

There were no deviations to the CAIP requirements.

\section{A.9.2 Investigation Results}

The following sections provide CAS-specific details of the sampling, FSRs, and sample selection and analysis.

\section{A.9.2.1 Soil Sampling}

Three surface burn areas were used to bias surface soil ( 0 to $1 \mathrm{ft}$ bgs) sample locations as specified in the CAIP. All samples were sent to the laboratory for analysis. In addition, one equipment rinsate sample was collected and analyzed. Samples were collected using a disposable scoop.

\section{A.9.2.2 Field-Screening Results}

Soil samples were field screened for VOCs and alpha and beta/gamma radiation. The FSRs were compared to FSLs to guide sampling decisions. The VOC headspace FSLs were not exceeded during sampling activities. No samples had elevated FSRs for alpha and beta/gamma radiation. 


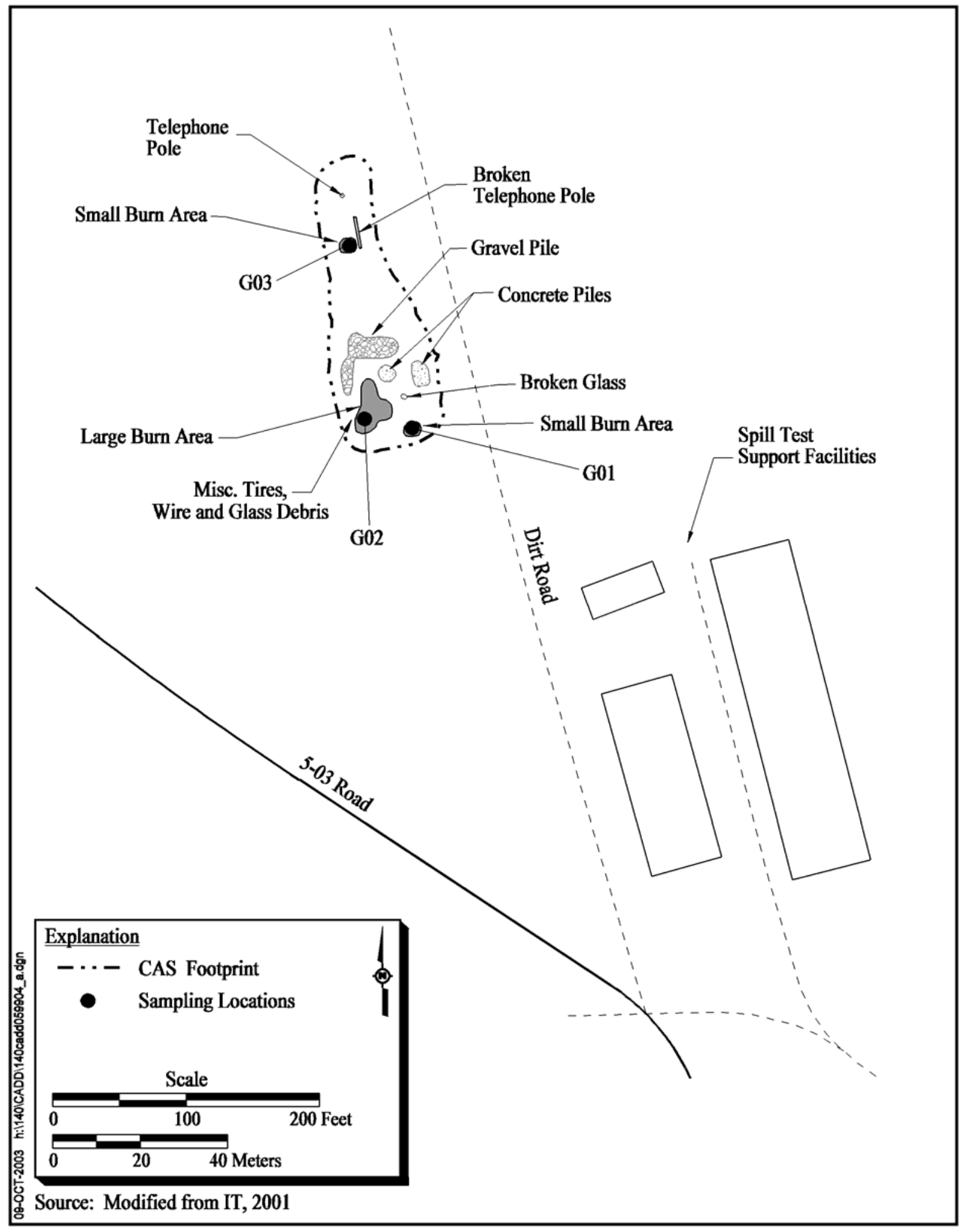

Figure A.9-1

Sampling Locations and Points of Interest at CAS 05-99-04, Burn Pits 
Table A.9-1

Samples Collected at CAS 05-99-04, Burn Pit

\begin{tabular}{||c|c|c|c|c|c||}
\hline $\begin{array}{c}\text { Sample } \\
\text { Number }\end{array}$ & Borehole & $\begin{array}{c}\text { Depth } \\
\text { (ft bgs) }\end{array}$ & $\begin{array}{c}\text { Sample } \\
\text { Matrix }\end{array}$ & Purpose & Analyses \\
\hline \hline $140 \mathrm{G} 001$ & $\mathrm{G} 01$ & $0-1$ & Soil & SC & Set 6 \\
\hline $140 \mathrm{G} 002$ & $\mathrm{G} 02$ & $0-1$ & Soil & SC & Set 6 \\
\hline $140 \mathrm{G} 003$ & $\mathrm{G} 03$ & $0-1$ & Soil & SC & Set 6 \\
\hline $140 \mathrm{G} 301$ & NA & NA & Water & Trip Blank & Total VOCs \\
\hline $140 \mathrm{G} 302$ & NA & NA & Water & $\begin{array}{c}\text { Equipment } \\
\text { Rinsate Blank }\end{array}$ & Set 6 \\
\hline $140 G 303$ & NA & NA & Water & Trip Blank & Total VOCs \\
\hline
\end{tabular}

Set $6=$ Total VOCs, Total SVOCs, TPH (DRO and GRO), PCBs, Nickel, Zinc, and Total RCRA Metals

$\mathrm{ft}$ bgs $=$ Feet below ground surface

$\mathrm{SC}=$ Site characterization

$\mathrm{NA}=$ Not applicable

\section{A.9.2.3 Sample Analyses}

Investigation soil samples were analyzed for CAIP-specified COPCs including total VOCs, total SVOCs, total RCRA metals plus zinc and nickel, TPH (DRO and GRO), and PCBs. The analytical parameters and laboratory analytical methods used to analyze the investigation samples are listed in Table A.2-1. Table A.9-1 lists the sample-specific analytical parameters.

\section{A.9.2.4 Analytes Detected Above Minimum Reporting Limits}

The analytical results detected at concentrations exceeding the MRLs as established in the CAIP (NNSA/NV, 2002a) are summarized in the following sections. These results were compared to PALs (also established in the CAIP) and are a subset of those that exceed MRLs. All of the analytical results obtained through sample analysis are usable.

\section{A.9.2.4.1 Total Volatile Organic Compound Analytical Results for Soil Samples}

Total VOCs analytical results for soil samples did not exceed the MRLs.

\section{A.9.2.4.2 Total Semivolatile Organic Compound Analytical Results for Soil Samples}

Total SVOCs analytical results for soil samples did not exceed the MRLs. 


\section{A.9.2.4.3 Total Petroleum Hydrocarbons Analytical Results for Soil Samples}

Analytical results for total TPH in soil samples exceeding the MRLs are shown in Table A.9-2. No results exceeded the PAL.

Table A.9-2

Soil Sample Results for TPH-DRO Detected Above Minimum Reporting Limits at CAS 05-99-04

\begin{tabular}{|c|c|c|c|}
\hline \multirow{2}{*}{$\begin{array}{l}\text { Sample } \\
\text { Number }\end{array}$} & \multirow{2}{*}{$\begin{array}{c}\text { Sample } \\
\text { Location }\end{array}$} & \multirow{2}{*}{$\begin{array}{c}\text { Depth } \\
\text { (ft bgs) }\end{array}$} & Contaminants of Potential Concern $(\mathrm{mg} / \mathrm{kg})$ \\
\hline & & & Diesel-Range Organics \\
\hline \multicolumn{3}{|c|}{ Preliminary Action Levels ${ }^{a}$} & 100 \\
\hline$\overline{140 \mathrm{G002}}$ & $\overline{\mathrm{G} 02}$ & $\overline{0-1}$ & $\overline{22(J)}$ \\
\hline
\end{tabular}

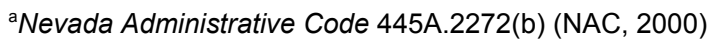

$\mathrm{ft}$ bgs $=$ Feet below ground surface

$\mathrm{mg} / \mathrm{kg}=$ Milligrams per kilogram

$\mathrm{J}=$ Estimated value. Qualifier added to laboratory data; record accepted. Total extractable petroleum hydrocarbons result quantitated from diesel standard calibration.

\section{A.9.2.4.4 Total RCRA Metals Analytical Results for Soil Samples}

The total RCRA metals plus nickel and zinc detected in soil samples at concentrations exceeding MRLs are listed in Table A.9-3. No metals were detected in soil at concentrations exceeding the PALs.

\section{A.9.2.4.5 Polychlorinated Biphenyl Results for Soil Samples}

The PCBs analytical results for soil samples did not exceed the MRLs.

\section{A.9.2.5 Contaminants of Concern}

Based on the aforementioned analytical results, no COCs were identified in the soil at this CAS.

\section{A.9.3 Nature and Extent of Contaminants of Concern}

No COCs were identified in the soil at this CAS. 
Table A.9-3

Soil Sample Results for Total RCRA Metals Detected Above Minimum Reporting Limits at CAS 05-99-04

\begin{tabular}{|c|c|c|c|c|c|c|c|c||}
\hline \multirow{2}{*}{$\begin{array}{c}\text { Sample } \\
\text { Number }\end{array}$} & \multirow{2}{*}{$\begin{array}{c}\text { Sample } \\
\text { Location }\end{array}$} & \multirow{2}{*}{$\begin{array}{c}\text { Depth } \\
\text { (ft bgs) }\end{array}$} & \multicolumn{6}{|c|}{ Contaminants of Potential Concern (mg/kg) } \\
\cline { 5 - 10 } & & & Arsenic & Barium & Chromium & Lead & Nickel & Zinc \\
\hline \multicolumn{2}{|c|}{ Preliminary Action Levels ${ }^{\mathbf{a}}$} & $\mathbf{2 3}$ & $\mathbf{1 0 0 , 0 0 0}$ & $\mathbf{4 5 0}$ & $\mathbf{7 5 0}$ & $\mathbf{4 1 , 0 0 0}$ & $\mathbf{1 0 0 , 0 0 0}$ \\
\hline \hline $140 \mathrm{G} 001$ & $\mathrm{G} 01$ & $0-1$ & 4.1 & 190 & 7 & 8.7 & 6.1 & 130 \\
\hline $140 \mathrm{G} 002$ & $\mathrm{G} 02$ & $0-1$ & 3.7 & 200 & 7.2 & 9.8 & 6 & 310 \\
\hline $140 \mathrm{G} 003$ & $\mathrm{G} 03$ & $0-1$ & 4.3 & 200 & 7.2 & 8.5 & 6.1 & 220 \\
\hline
\end{tabular}

aBased on U.S. Environmental Protection Agency, Region 9 Preliminary Remediation Goals (PRGs) (EPA, 2000). Arsenic is the mean plus two times the standard deviation of the mean for sediment samples collected by the NBMG throughout the NTTR (NBMG, 1998; Moore, 1999)

$\mathrm{ft}$ bgs = Feet below ground surface $\mathrm{mg} / \mathrm{kg}=$ Milligrams per kilogram

\section{A.9.4 Revised Conceptual Site Model}

No variations to the CSM were identified. 


\section{A.10.0 Radioactive Waste Dump (CAS 22-99-04)}

Corrective Action Site 22-99-04 (Figure A.10-1) is located in the Mercury Valley approximately $0.2 \mathrm{mi}$ south-southwest of the Weather Observatory, Building 22-01. A bermed area of deteriorating sandbags, approximately 6 by $10 \mathrm{ft}$, identifies the CAS. A geophysical survey did not identify buried debris. The soil in the area is typical of the area, and the vegetation does not appear to be stressed.

This site is presumed to have been used for radioactive source material storage based upon the word "dump" used to signify "storage" by the U.S. Army. In 1997, BN removed fencing around CAS 22-99-04 because it was believed at that time that the site was a storage area rather than a disposal area. More details are provided in the CAIP (NNSA/NV, 2002a).

\section{A.10.1 Corrective Action Investigation}

One investigation sample was collected during the investigation activities as listed in Table A.10-1. The actual sample location corresponds with the planned sample location identified in the CAIP and is shown in Figure A.10-1. The specific CAI activities conducted to meet CAIP requirements are described in the following sections.

\section{A.10.1.1 Deviations}

There were no deviations to the CAIP requirements; therefore, the CAIP requirements were met.

\section{A.10.2 Investigation Results}

The following sections provide CAS-specific details of the sampling, FSRs, and sample collection and analysis.

\section{A.10.2.1 Hand Sampling}

Hand sampling was conducted using a disposable scoop to access the surface ( 0 to $1 \mathrm{ft}$ bgs) horizon and collect a sample at the biased location presented in the CAIP. A total of one soil sample was collected at this CAS. This soil sample was submitted for laboratory analyses. 


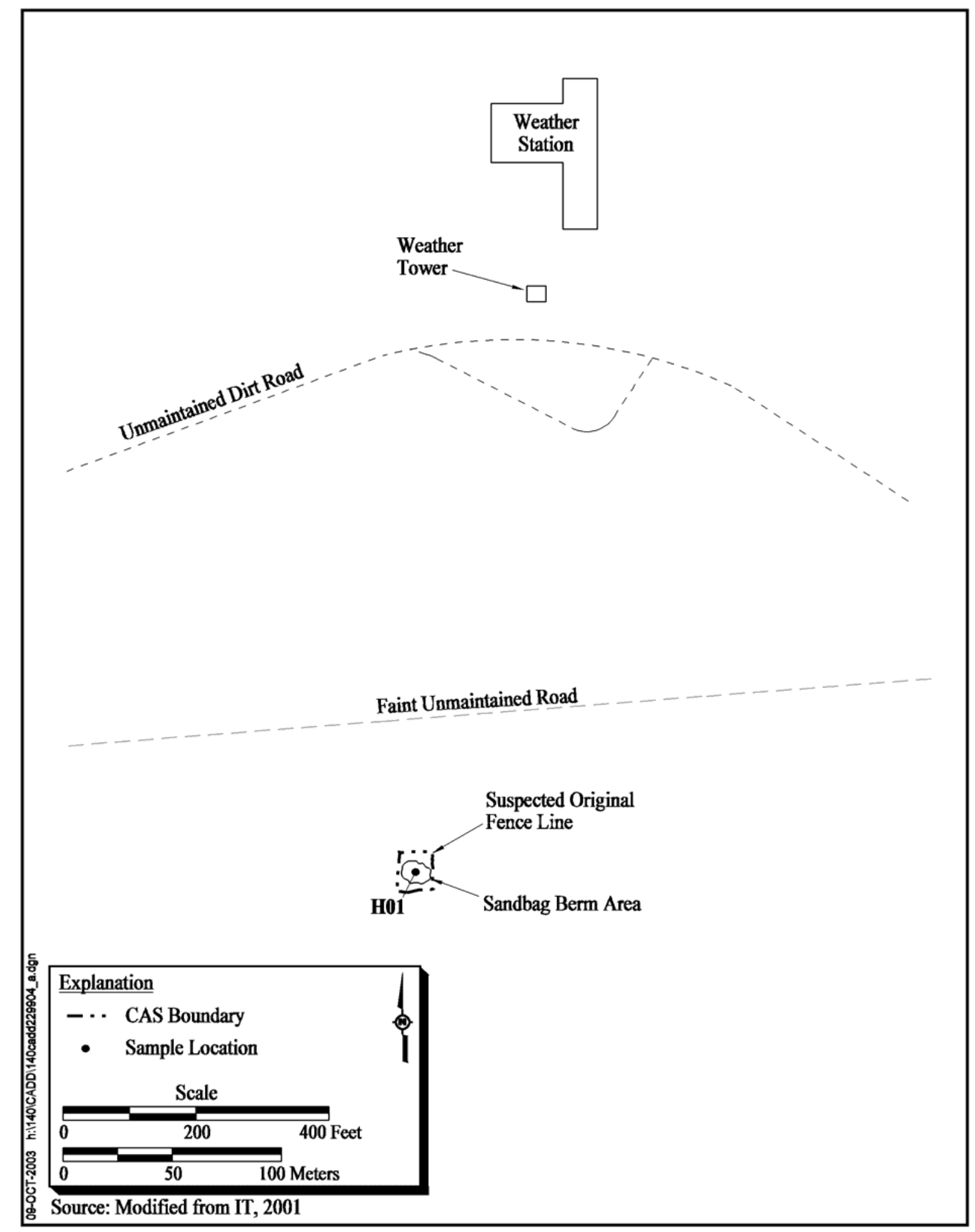

Figure A.10-1

Sampling Location at CAS 22-99-04, Radioactive Waste Dump 
Table A.10-1

Samples Collected at CAS 22-99-04, Radioactive Waste Dump

\begin{tabular}{|c|c|c|c|c|c|}
\hline $\begin{array}{c}\text { Sample } \\
\text { Number }\end{array}$ & Borehole & $\begin{array}{c}\text { Depth } \\
\text { (ft bgs) }\end{array}$ & $\begin{array}{c}\text { Sample } \\
\text { Matrix }\end{array}$ & Purpose & Analyses \\
\hline \hline $140 \mathrm{H} 001$ & $\mathrm{H} 01$ & $0-1$ & Soil & SC & $\begin{array}{c}\text { PCBs, Gamma Spectrometry, } \\
\text { Gross Beta, Strontium-90 }\end{array}$ \\
\hline
\end{tabular}

$\mathrm{ft}$ bgs $=$ Feet below ground surface

$\mathrm{SC}=$ Site characterization

\section{A.10.2.2 Field-Screening Results}

The soil sample was field screened for VOCs and alpha and beta/gamma radiation. The FSRs were compared to FSLs to guide sampling decisions. The sample did not exceed FSLs.

\section{A.10.2.3 Sample Analyses}

The investigation soil sample was analyzed for CAIP-specified COPCs including PCBs, gross beta, Sr-90, and gamma-emitting radionuclides. The analytical parameters and laboratory analytical methods used to analyze the investigation samples are listed in Table A.2-1. Table A.10-1 lists the sample-specific analytical parameters.

\section{A.10.2.4 Analytes Detected Above Minimum Reporting Limits}

The analytical results detected at concentrations exceeding the MRLs as established in the CAIP (NNSA/NV, 2002a) are summarized in the following sections. These results were compared to PALs (also established in the CAIP) and are a subset of those that exceed MRLs. All of the analytical results obtained through sample analysis are usable.

\section{A.10.2.4.1 Polychlorinated Biphenyl Results for Soil Samples}

No PCB analytical results for soil exceeded the MRLs.

\section{A.10.2.4.2 Gamma Spectrometry Results for Soil Samples}

Gamma spectrometry analytical results for detected radionuclide concentrations exceeding the MRLs are shown in Table A.10-2. The results did not exceed the PALs. 
Table A.10-2

Soil Sample Results for Gamma-Emitting Radionuclides

Detected Above Minimum Reporting Limits at CAS 22-99-04

\begin{tabular}{|c|c|c|c|c|c|c|c|c|c|}
\hline \multirow{2}{*}{$\begin{array}{l}\text { Sample } \\
\text { Number }\end{array}$} & \multirow{2}{*}{$\begin{array}{c}\text { Sample } \\
\text { Location }\end{array}$} & \multirow{2}{*}{$\begin{array}{c}\text { Depth } \\
\text { (ft bgs) }\end{array}$} & \multicolumn{7}{|c|}{ Contaminants of Potential Concern (pCi/g) } \\
\hline & & & Actinium-228 & Bismuth-214 & Cesium-137 & Lead-212 & Lead-214 & Potassium-40 & Thallium-208 \\
\hline \multicolumn{3}{|c|}{ Preliminary Action Levels } & $3.64^{\mathrm{a}}$ & $3.47^{\mathrm{a}}$ & $7.033^{b}$ & $3.64^{a}$ & $3.47^{\mathrm{a}}$ & $97.7^{\mathrm{a}}$ & $3.38^{\mathrm{a}}$ \\
\hline $140 \mathrm{H} 001$ & $\mathrm{H} 01$ & $0-1$ & $0.87 \pm 0.25$ & $0.72 \pm 0.20$ & $0.242 \pm 0.089$ & $\begin{array}{c}1.07 \pm \\
0.23\end{array}$ & $0.79 \pm 0.18$ & $15.5 \pm 3.1$ & $0.303 \pm 0.090$ \\
\hline
\end{tabular}

aBased on background concentration listed in Environmental Monitoring Report for the Proposed Ward Valley, California, Low-Level Radioactive Waste (LLRW) Facility (US Ecology and Atlan-Tech, 1992)

bBased on background concentration listed or derived in Off-Site Radiation Exposure Review Project, Phase I/ Soil Program (McArthur and Miller, 1989).

$\mathrm{ft}$ bgs $=$ Feet below ground surface

$\mathrm{pCi} / \mathrm{g}=$ Picocuries per gram

\section{A.10.2.4.3 Gross Beta}

The gross beta analytical result exceeding the MRL is shown in Table A.10-3. This result did not exceed the PAL.

Table A.10-3

Soil Sample Results for Gross Beta Detected Above Minimum Reporting Limits at CAS 22-99-04

\begin{tabular}{|c|c|c|c|}
\hline \multirow{2}{*}{$\begin{array}{c}\text { Sample } \\
\text { Number }\end{array}$} & $\begin{array}{c}\text { Sample } \\
\text { Location }\end{array}$ & $\begin{array}{c}\text { Depth } \\
\text { (ft bgs) }\end{array}$ & Contaminants of Potential Concern (pCi/g) \\
\cline { 3 - 4 } & \multicolumn{2}{|c|}{ Preliminary Action Levels } & Gross Beta \\
\hline \hline \multicolumn{2}{|c|}{ NA } \\
\hline \hline $140 \mathrm{H} 001$ & $\mathrm{H} 01$ & $0-1$ & $5.4 \pm 1.6$ \\
\hline
\end{tabular}

$\mathrm{ft}$ bgs $=$ Feet below ground surface $\mathrm{pCi} / \mathrm{g}=$ Picocuries per gram

\section{A.10.2.4.4 Strontium-90 Results for Soil Samples}

Strontium-90 was not detected above the MRL in the soil samples collected at this CAS.

\section{A.10.2.5 Contaminants of Concern}

No COCs were identified in this CAS. 


\section{A.10.3 Nature and Extent of Contaminants of Concern}

No COCs were identified in this CAS.

\section{A.10.4 Revised Conceptual Site Model}

No variations to the CSM were identified. 


\section{A.11.0 Hazardous Waste Storage Area, (CAS 23-17-01)}

Corrective Action Site 23-17-01 is located adjacent to the Area 23 Sanitary Landfill. The site is the historical location of a surface HWSA, an area of elevated electromagnetic conductivity adjacent to the HWSA, and a subsurface landfill beneath part of the HWSA.

The HWSA (Figure A.11-1), measuring approximately 100 by $300 \mathrm{ft}$, has since been covered with gravel and is devoid of vegetation. The site is currently used as a parking and storage area for sanitary waste management activities. The Area 23 HWSA was in operation from 1982 to late November 1990. Interviews indicate that waste was stored on the ground, without any lining between the containers and the soil. It was noted that material released to the soil had been cleaned up (Williams, 1998). No sampling data or closure report was found.

Additionally, a landfill (Figure A.11-2) is located beneath and adjacent to the HWSA. The information obtained during an interview indicates that the landfill cells were believed to have been used for sanitary waste (Norvell, 2001). The landfill was identified by a geophysical survey and confirmed to be present during the CAI. More details are provided in the CAIP (NNSA/NV, 2002a).

\section{A.11.1 Corrective Action Investigation}

Sixty-four investigation samples and associated QC samples were collected during investigation activities at this CAS and are listed in Table A.11-1. The actual sample locations correspond with the planned sample locations identified in the CAIP and are shown in Figure A.11-1 and Figure A.11-2. The specific CAI activities conducted to meet CAIP requirements are described in the following sections.

\section{A.11.1.1 Deviations}

There were no deviations to the CAIP requirements; therefore, the CAIP requirements were met.

\section{A.11.2 Investigation Results}

The following sections provide CAS-specific details of the inspection of the landfill features, sampling, FSRs, and sample collection and analysis. 


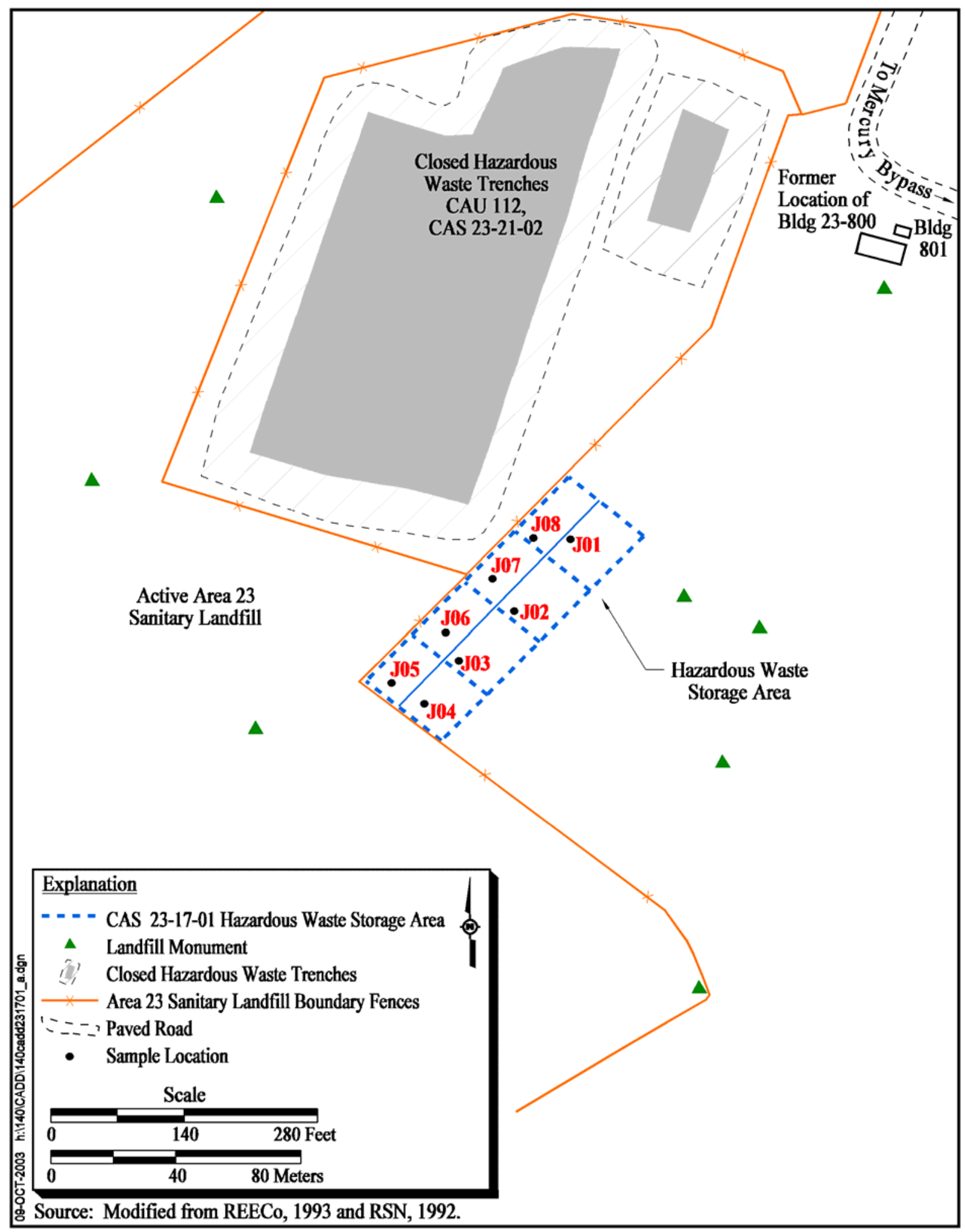

Figure A.11-1

Sampling Locations at CAS 23-17-01, Hazardous Waste Storage Area (Surface Area) 


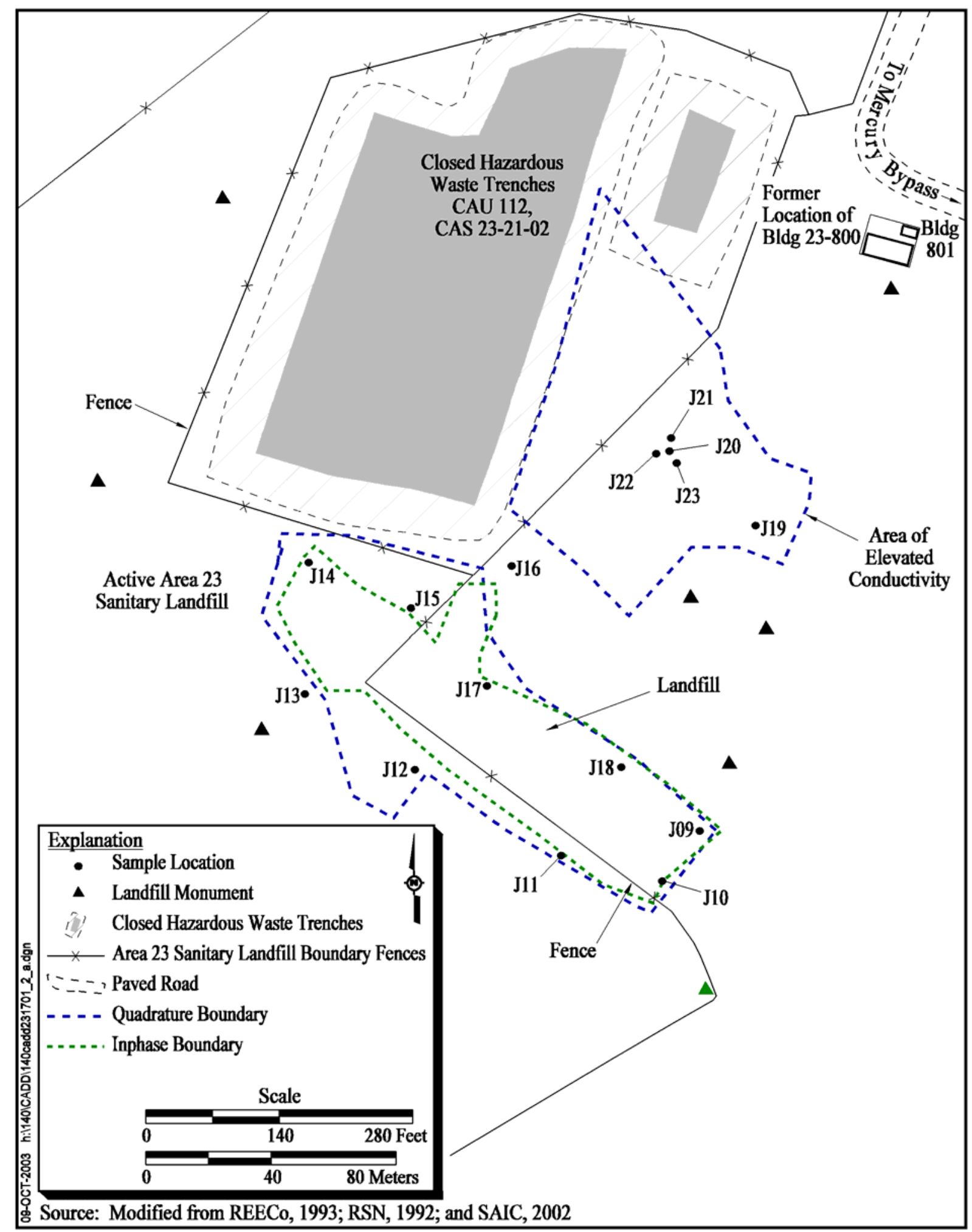

Figure A.11-2

Sampling Locations at CAS 23-17-01, Hazardous Waste Storage Area (Landfill Area) 
Table A.11-1

Samples Collected at CAS 23-17-01, Hazardous Waste Storage Area (Page 1 of 3 )

\begin{tabular}{|c|c|c|c|c|c|}
\hline $\begin{array}{l}\text { Sample } \\
\text { Number }\end{array}$ & Borehole & $\begin{array}{c}\text { Depth } \\
\text { (ft bgs) }\end{array}$ & $\begin{array}{l}\text { Sample } \\
\text { Matrix }\end{array}$ & Purpose & Analyses \\
\hline 140J001 & J01 & $0-1$ & Soil & $\overline{S C}$ & Set 7 \\
\hline 140J002 & J01 & $3-4$ & Soil & SC & Set 7 \\
\hline 140J003 & $\mathrm{J} 02$ & $0-1$ & Soil & SC & Set 7 \\
\hline 140J004 & $\mathrm{J} 02$ & $3-4$ & Soil & SC & Set 7 \\
\hline 140J005 & $\mathrm{J03}$ & $0-1$ & Soil & $\mathrm{SC}$ & Set 7 \\
\hline 140J006 & $\mathrm{J} 03$ & $3-4$ & Soil & SC & Set 7 \\
\hline 140J007 & $\mathrm{J} 04$ & $0-1$ & Soil & SC & Set 7 \\
\hline 140J008 & $\mathrm{J} 04$ & $3-4$ & Soil & SC & Set 7 \\
\hline 140J009 & J05 & $0-1$ & Soil & SC & Set 7 \\
\hline 140J010 & J05 & $3-4$ & Soil & SC & Set 7 \\
\hline 140J011 & J06 & $0-1$ & Soil & SC & Set 7 \\
\hline 140J012 & J06 & $3-4$ & Soil & SC & Set 7 \\
\hline 140J013 & J07 & $0-1$ & Soil & SC & Set 7 \\
\hline 140J014 & J07 & $3-4$ & Soil & SC & Set 7 \\
\hline 140J015 & $\mathrm{J} 08$ & $0-1$ & Soil & $\mathrm{SC}$ & Set 7 \\
\hline 140J016 & $\mathrm{J} 08$ & $3-4$ & Soil & SC & Set 7 \\
\hline 140J017 & $\mathrm{J} 10$ & $4-5$ & Soil & SC & Set 7 \\
\hline 140J018 & $\mathrm{J} 10$ & $9-10$ & Soil & SC & Set 7 \\
\hline 140J019 & $\mathrm{J} 10$ & $14-15$ & Soil & SC & Set 7 \\
\hline 140J020 & $\mathrm{J} 09$ & $4-5$ & Soil & SC & Set 7 \\
\hline 140J021 & $\mathrm{J} 09$ & $9-10$ & Soil & SC & Set 7 \\
\hline 140J022 & $\mathrm{J} 09$ & $14-15$ & Soil & SC & Set 7 \\
\hline 140J023 & $\mathrm{J} 18$ & $4-5$ & Soil & $\mathrm{SC}$ & Set 7 \\
\hline 140J024 & $\mathrm{J} 18$ & $9-10$ & Soil & SC & Set 7 \\
\hline 140J025 & $\mathrm{J} 18$ & $14-15$ & Soil & SC & Set 7 \\
\hline 140J026 & $\mathrm{J} 17$ & $4-5$ & Soil & SC & Set 7 \\
\hline 140J027 & $\mathrm{J} 17$ & $9-10$ & Soil & $\mathrm{SC}$ & Set 7 \\
\hline 140J028 & $\mathrm{J} 17$ & $14-15$ & Soil & SC & Set 7 \\
\hline 140J029 & $\mathrm{J} 16$ & $4-5$ & Soil & SC & Set 7 \\
\hline 140J030 & $\mathrm{J} 16$ & $9-10$ & Soil & SC & Set 7 \\
\hline 140J031 & $\mathrm{J} 16$ & $14-15$ & Soil & SC & Set 7 \\
\hline 140J032 & $\mathrm{J} 15$ & $4-5$ & Soil & SC & Set 7 \\
\hline 140J033 & $\mathrm{J} 15$ & $9-10$ & Soil & SC & Set 7 \\
\hline
\end{tabular}


Table A.11-1

Samples Collected at CAS 23-17-01, Hazardous Waste Storage Area (Page 2 of 3 )

\begin{tabular}{|c|c|c|c|c|c|}
\hline $\begin{array}{l}\text { Sample } \\
\text { Number }\end{array}$ & Borehole & $\begin{array}{c}\text { Depth } \\
\text { (ft bgs) }\end{array}$ & $\begin{array}{c}\text { Sample } \\
\text { Matrix }\end{array}$ & Purpose & Analyses \\
\hline 140J034 & $\overline{J 15}$ & $\overline{14-15}$ & $\overline{\text { Soil }}$ & $\overline{\overline{S C}}$ & $\overline{\text { Set } 7}$ \\
\hline 140J035 & J14 & $4-5$ & Soil & SC & Set 7 \\
\hline 140J036 & J14 & $9-10$ & Soil & SC & Set 7 \\
\hline 140J037 & J14 & $14-15$ & Soil & SC & Set 7 \\
\hline 140J038 & $\mathrm{J} 13$ & $4-5$ & Soil & SC & Set 7 \\
\hline 140J039 & $\mathrm{J} 13$ & $9-10$ & Soil & $\mathrm{SC}$ & Set 7 \\
\hline 140J040 & $\mathrm{J} 13$ & $14-15$ & Soil & SC & Set 7 \\
\hline 140J041 & $\mathrm{J} 12$ & $4-5$ & Soil & SC & Set 7 \\
\hline 140J042 & $\mathrm{J} 12$ & $9-10$ & Soil & SC & Set 7 \\
\hline 140J043 & $\mathrm{J} 12$ & $14-15$ & Soil & SC & Set 7 \\
\hline 140J044 & J11 & $4-5$ & Soil & SC & Set 7 \\
\hline 140J045 & J11 & $9-10$ & Soil & SC & Set 7 \\
\hline 140J046 & J11 & $14-15$ & Soil & $\mathrm{SC}$ & Set 7 \\
\hline 140J047 & J19 & $9-10$ & Soil & SC & Set 7 \\
\hline 140J048 & J19 & $14-15$ & Soil & SC & Set 7 \\
\hline 140J049 & $\mathrm{J} 20$ & $9-10$ & Soil & SC & Set 7 \\
\hline 140J050 & $\mathrm{J} 20$ & $14-15$ & Soil & SC & Set 7 \\
\hline 140J051 & $\mathrm{J} 20$ & $0-1$ & Soil & SC & TPH-DRO \\
\hline 140J052 & $\mathrm{J} 20$ & $4-5$ & Soil & SC & TPH-DRO \\
\hline 140J053 & $\mathrm{J} 21$ & $0-1$ & Soil & SC & TPH-DRO \\
\hline 140J054 & $\mathrm{J} 21$ & $4-5$ & Soil & $\begin{array}{c}\text { SC, } \\
\text { Lab QC }\end{array}$ & TPH-DRO \\
\hline 140J055 & $\mathrm{J} 21$ & $9-10$ & Soil & SC & TPH-DRO \\
\hline 140J056 & $\mathrm{J} 21$ & $14-15$ & Soil & SC & TPH-DRO \\
\hline 140J057 & $\mathrm{J} 23$ & $0-1$ & Soil & SC & TPH-DRO \\
\hline 140J058 & $\mathrm{J} 23$ & $4-5$ & Soil & SC & TPH-DRO \\
\hline 140J059 & $\mathrm{J} 23$ & $9-10$ & Soil & $\mathrm{SC}$ & TPH-DRO \\
\hline 140J060 & $\mathrm{J} 23$ & $9-10$ & Soil & $\begin{array}{c}\text { Field Duplicate } \\
\text { of } 140 \mathrm{~J} 059\end{array}$ & TPH-DRO \\
\hline 140J061 & $\mathrm{J} 23$ & $14-15$ & Soil & SC & TPH-DRO \\
\hline 140J062 & $\mathrm{J} 22$ & $0-1$ & Soil & SC & TPH-DRO \\
\hline 140J063 & $\mathrm{J} 22$ & $4-5$ & Soil & SC & TPH-DRO \\
\hline 140J064 & $\mathrm{J} 22$ & $9-10$ & Soil & SC & TPH-DRO \\
\hline 140J065 & $\mathrm{J} 22$ & $14-15$ & Soil & SC & TPH-DRO \\
\hline
\end{tabular}


Table A.11-1

Samples Collected at CAS 23-17-01, Hazardous Waste Storage Area (Page 3 of 3 )

\begin{tabular}{|c|c|c|c|c|c|}
\hline $\begin{array}{l}\text { Sample } \\
\text { Number }\end{array}$ & Borehole & $\begin{array}{c}\text { Depth } \\
\text { (ft bgs) }\end{array}$ & $\begin{array}{l}\text { Sample } \\
\text { Matrix }\end{array}$ & Purpose & Analyses \\
\hline 140J301 & $\overline{N A}$ & $\mathrm{NA}$ & Water & Trip Blank & Total VOCs \\
\hline 140J302 & $\mathrm{J} 03$ & $0-1$ & Soil & $\mathrm{SC}, \mathrm{MS} / \mathrm{MSD}$ & Set 7 \\
\hline 140J303 & NA & NA & Water & Trip Blank & Total VOCs \\
\hline 140J304 & NA & NA & Water & $\begin{array}{c}\text { Equipment } \\
\text { Rinsate Blank }\end{array}$ & Set 7 \\
\hline 140J305 & NA & NA & Water & Field Blank & Set 7 \\
\hline 140J306 & NA & NA & Water & Trip Blank & Total VOCs \\
\hline 140J307 & $\mathrm{J} 17$ & $14-15$ & Soil & SC, MS/MSD & Set 7 \\
\hline 140J308 & $\begin{array}{l}\text { Area Between } \\
\mathrm{J} 17 \text { and J18 }\end{array}$ & NA & Water & Source Blank & Set 7 \\
\hline 140J309 & $\begin{array}{l}\text { Area Between } \\
\mathrm{J} 17 \text { and J18 }\end{array}$ & NA & Water & Source Blank & Set 7 \\
\hline 140J310 & $\mathrm{NA}$ & NA & Water & Trip Blank & Total VOCs \\
\hline 140J311 & NA & NA & Water & Field Blank & Set 7 \\
\hline 140J312 & NA & NA & Water & $\begin{array}{c}\text { Equipment } \\
\text { Rinsate Blank }\end{array}$ & Set 7 \\
\hline 140J313 & NA & NA & Water & Trip Blank & Total VOCs \\
\hline 140J314 & $\mathrm{J} 14$ & $14-15$ & Soil & $\begin{array}{c}\text { Field Duplicate } \\
\text { of } 140 \mathrm{~J} 037\end{array}$ & Set 7 \\
\hline 140J315 & NA & NA & Water & Trip Blank & Total VOCs \\
\hline 140J316 & NA & NA & Water & Field Blank & TPH-DRO \\
\hline 140J317 & NA & NA & Water & $\begin{array}{c}\text { Equipment } \\
\text { Rinsate Blank }\end{array}$ & TPH-DRO \\
\hline 140JGT1 & J18 & $2.5-3.5$ & Soil & Geotechnical & Set 8 \\
\hline 140JGT2 & J18 & $15.5-16.5$ & Soil & Geotechnical & Set 8 \\
\hline
\end{tabular}

Set 7 = Total VOCs, Total SVOCs, TPH (DRO and GRO), Ethylene Glycol, Herbicides, Total RCRA Metals, Pesticides, Tritium, and PCBs

Set 8 = Moisture content, bulk density, calculated total porosity, saturated hydraulic conductivity, calculated unsaturated hydraulic conductivity, particle-size analysis/soil classification, and moisture characteristics

$\mathrm{ft}$ bgs $=$ Feet below ground surface

MS/MSD = Matrix spike/matrix spike duplicate

$\mathrm{SC}=$ Site characterization

NA $=$ Not applicable

$\mathrm{QC}=$ Quality control 


\section{A.11.2.1 Geophysical Survey}

A geophysical survey was conducted at CAS 23-17-01 to determine the lateral extent of buried waste, the landfill thickness, trench orientation, and any utilities within close proximity (SAIC, 2002). An EM31-DL (EM31) survey was conducted along southeast to northwest traverses with a 10-ft traverse separation. The EM31 survey identified subsurface metallic debris indicating the presence of a landfill. The landfill trends northwest to southeast. An anomalous extension to the landfill appears to exist parallel to a portion of the present boundary fence. This feature could not be further delineated because of limited access.

In addition, the survey indicated an area of elevated conductivity adjacent to the HWSA, which may be a remnant topographic drainage that has been in-filled. No other linear features were identified during the survey.

Following the EM31 survey, two Electrical Imaging (EI) survey traverses were conducted to determine the vertical limits of the buried waste material in the landfill. The EI traverses extended northeast to southwest across the landfill. The EI survey indicated the landfill base is approximately 10 to $14 \mathrm{ft}$ bgs at the two traverses.

\section{A.11.2.2 Inspection of the Landfill Dimensions}

Excavations with a backhoe were used to better define the landfill dimensions, the thickness of the landfill cover, and to establish sampling locations around the perimeter of the landfill. Soil samples were collected using a rotosonic drill rig. Excavation locations were preselected based on the results of the geophysical survey. Backhoe trenches were generally oriented perpendicular to the trace of the disposal feature boundary, and were started outside of the boundary and worked inward. As soon as debris was observed, the location was noted and staked, and the trench backfilled. In this manner, disposal features were minimally penetrated.

Ten exploratory excavations (adjacent to sampling locations J09 through J18) were dug to investigate the landfill dimensions (Figure A.11-3). The excavations showed the lateral boundaries of the landfill to be smaller than indicated by the geophysical survey, as shown in Figure A.11-3. The excavations showed the landfill cap to be at least 2.5-ft thick. Sampling locations J09 through J18 were drilled just outside the landfill boundary. The wall of the landfill slopes up towards these 


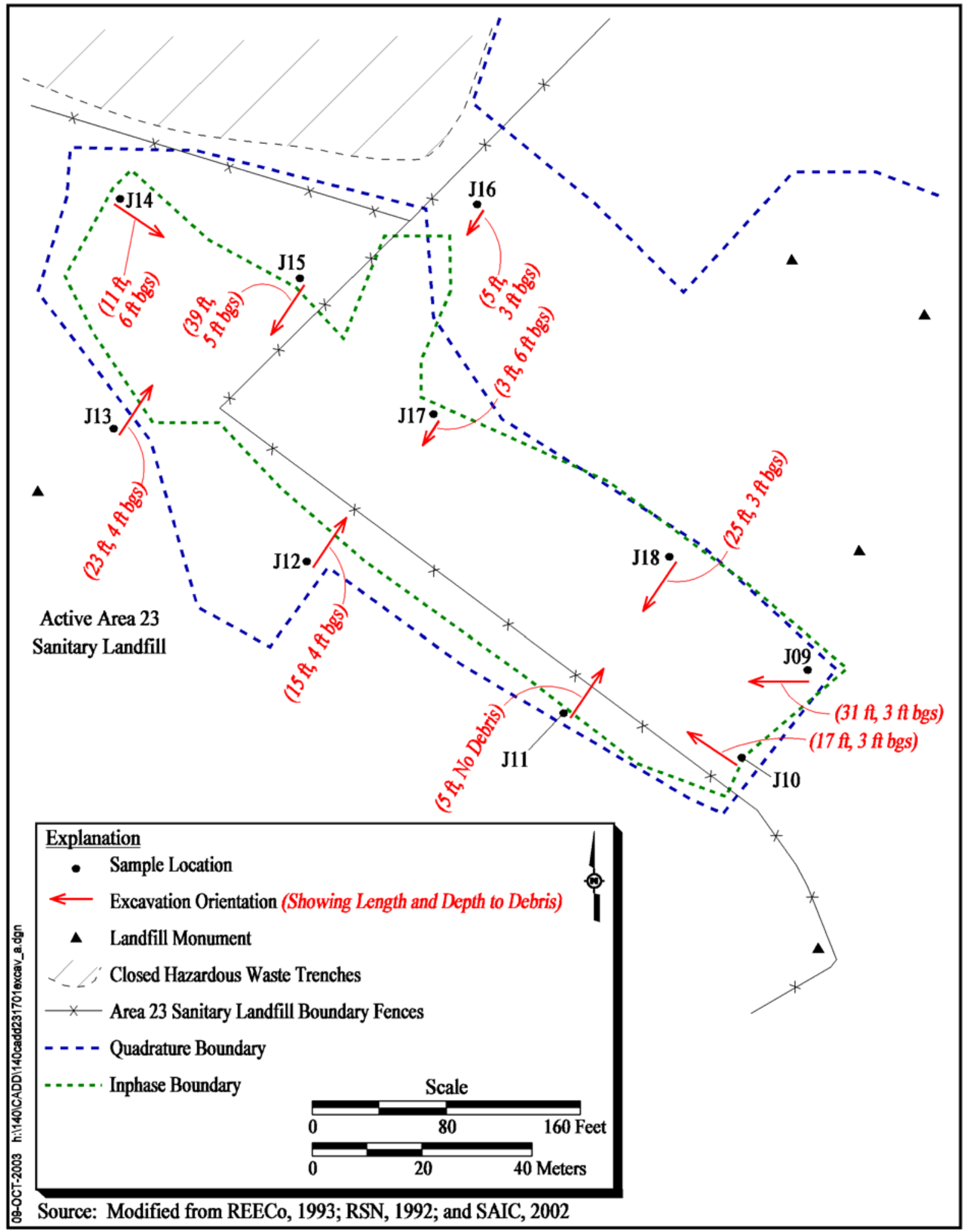

Figure A.11-3

Excavation Locations at CAS 23-17-01, Hazardous Waste Storage Area (Landfill Area) 64 
sampling locations. Two excavations were dug through the east edge of the landfill starting adjacent to $\mathrm{J} 09$ and $\mathrm{J} 10$ and going $31 \mathrm{ft}$ and $17 \mathrm{ft}$, respectively, towards the landfill; the landfill cover at these locations were both 3-ft thick. On the south side of the landfill, an excavation adjacent to J11 identified the sloping wall of the landfill but no debris was found up to the fence of the landfill. Excavations were dug adjacent to $\mathrm{J} 12$ and $\mathrm{J} 13$ going $15 \mathrm{ft}$ and $23 \mathrm{ft}$, respectively, towards the landfill. The cover at both locations was measured to be 4-ft thick. On the west side of the landfill, an excavation adjacent to $\mathrm{J} 14$ going $11 \mathrm{ft}$ towards the landfill identified debris at $6 \mathrm{ft}$ bgs. On the north side of the landfill, an excavation adjacent to J15 going $39 \mathrm{ft}$ towards the landfill identified debris at the 5-ft depth. An excavation adjacent to $\mathrm{J} 16$ going $5 \mathrm{ft}$ towards the landfill identified debris at $3 \mathrm{ft}$ bgs. An excavation adjacent to sampling locations J17 and J18 going $6 \mathrm{ft}$ and $25 \mathrm{ft}$, respectively, towards the landfill identified the cover to be 3-ft and 2.5-ft thick, respectively. Sanitary debris found at these locations included mattresses, clothing, wood, and plastic. Spoils were temporarily staged next to excavations. Excavated soil was returned as near to its original location as practical.

\section{A.11.2.3 Backhoe Sampling}

A backhoe was used to collect the surface ( 0 to $1 \mathrm{ft} \mathrm{bgs}$ ) and subsurface ( 4 to $5 \mathrm{ft}$ bgs) horizons at the HWSA at locations J01 through J08. The 16 soil samples were collected by hand from the backhoe bucket using a disposable scoop, as described in Section A.2.3.2.

\section{A.11.2.4 Rotosonic Sampling}

Thirty samples were collected just outside the perimeter of the landfill from ten locations with a rotosonic drill rig at three soil horizons from a 4 to $5 \mathrm{ft}, 9$ to $10 \mathrm{ft}$, and 14 to $15 \mathrm{ft}$ depth. This rig used a hollow-core barrel fitted with a standard carbide button bit. The core barrel was advanced via pull-down and rotation and when the barrel was full (or blocked, as was often the case), the barrel was brought to the surface and the contents extruded into long plastic bags.

The geophysics survey indicated an area of elevated conductivity adjacent to the HWSA. Eighteen samples were collected from the elevated conductivity area with a rotosonic drill rig. Two locations were planned and sampled from a 9 to $10 \mathrm{ft}$ and 14 to $15 \mathrm{ft}$ depth. One of these locations had TPH (DRO) concentrations above PALs, so samples were also collected from 0 to $1 \mathrm{ft}$ and 4 to $5 \mathrm{ft}$ at this 
location. Three step-outs borings were conducted and sampled from a 0 to $1 \mathrm{ft}, 4$ to $5 \mathrm{ft}, 9$ to $10 \mathrm{ft}$, and 14 to $15 \mathrm{ft}$ depth. Excess soil was returned to the sampling locations.

\section{A.11.2.5 Geotechnical Samples}

Geotechnical samples (140JGT1 and 140JGT2) were collected in the same fashion from the landfill cap (2.5 to $3.5 \mathrm{ft}$ bgs) and the native soil beneath the landfill (15.5 to $16.5 \mathrm{ft}$ bgs), except a split spoon loaded with decontaminated brass sleeves was used to preserve in situ conditions (Figure A.11-2). The sleeves were immediately capped, taped, labeled, and stored until shipment to the geotechnical laboratory. The results are summarized in Table A.11-2, and the complete report is maintained in the project files. The methods used for the geotechnical analysis are equivalent to those specified in the CAIP (NNSA/NV, 2002a).

\section{A.11.2.6 Topographic Survey of Landfill Surface}

A topographic survey of the landfill surface was conducted by BN to identify surface drainage patterns of the landfill cap and surrounding land surface. The survey showed the land surface to slope gently to the south. Results of this survey are in project files.

\section{A.11.2.7 Field-Screening Results}

Soil samples were field screened for VOCs, TPH, and alpha and beta/gamma radiation. The FSRs were compared to FSLs to guide sampling decisions. None of the samples exceeded FSLs for radiation or VOCs. The FSL was exceeded for TPH using the gas chromatograph (GC) at location J20 in sample 140J049 taken at a depth of 9 to $10 \mathrm{ft}$ bgs. The GC indicated a hydrocarbon concentration of $106 \mathrm{ppm}$. Analytical results from this sample showed a TPH (DRO) concentration of $320 \mathrm{ppm}$.

\section{A.11.2.8 Sample Analyses}

Investigation soil samples were analyzed for CAIP-specified COPCs including total VOCs, total SVOCs, total RCRA metals, TPH (DRO and GRO), PCBs, ethylene glycol, herbicides, pesticides, and tritium. The analytical parameters and laboratory analytical methods used to analyze the 
Table A.11-2

Geotechnical Data and Laboratory Analytical Methods for CAS 23-17-01

\begin{tabular}{|c|c|c|c|c|}
\hline Geotechnical Parameter & Actual Method(s) & Parameter/Units & $\begin{array}{l}\text { 140JGT1 } \\
\text { Results }\end{array}$ & $\begin{array}{l}\text { 140JGT2 } \\
\text { Results }\end{array}$ \\
\hline \multirow{2}{*}{ Initial moisture content } & \multirow{2}{*}{ ASTM $^{a}$ D 2216-92 } & Gravimetric $(\%, \mathrm{~g} / \mathrm{g})$ & 3.0 & 4.1 \\
\hline & & Volumetric $\left(\%, \mathrm{~cm}^{3} / \mathrm{cm}^{3}\right)$ & 5.7 & 6.7 \\
\hline \multirow{2}{*}{ Dry bulk density } & \multirow{2}{*}{ ASTM $^{\mathrm{a}}$ D 4531-91 } & Dry Bulk Density $\left(\mathrm{g} / \mathrm{cm}^{3}\right)$ & 1.86 & 1.64 \\
\hline & & Wet Bulk Density $\left(\mathrm{g} / \mathrm{cm}^{3}\right)$ & 1.92 & 1.71 \\
\hline Calculated porosity & 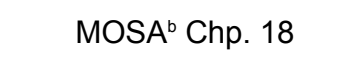 & Calculated Porosity (\%) & 29.7 & 38.2 \\
\hline $\begin{array}{l}\text { Saturated hydraulic } \\
\text { conductivity }\end{array}$ & ASTM $^{a}$ D 2434-68(93) & Ksat $(\mathrm{cm} / \mathrm{s})$ & $6.0 \mathrm{E}-04$ & $3.4 \mathrm{E}-03$ \\
\hline \multirow{4}{*}{$\begin{array}{l}\text { Unsaturated hydraulic } \\
\text { conductivity }\end{array}$} & \multirow{4}{*}{$\underline{\text { van Genuchten }}^{\mathrm{c}}$} & $\alpha\left(\mathrm{cm}^{-1}\right)$ & 0.0410 & 0.1526 \\
\hline & & $\mathrm{N}$ (dimensionless) & 1.3573 & 1.2997 \\
\hline & & $\Theta r$ & 0.0097 & 0.0056 \\
\hline & & $\Theta s$ & 0.2942 & 0.3822 \\
\hline \multirow{5}{*}{ Particle-size distribution } & \multirow{5}{*}{ ASTM $^{a}$ D 422-63(90) } & $\mathrm{d}_{10}(\mathrm{~mm})$ & 0.032 & 0.035 \\
\hline & & $\mathrm{d}_{50}(\mathrm{~mm})$ & 2.2 & 2.1 \\
\hline & & $\mathrm{d}_{60}(\mathrm{~mm})$ & 3.7 & 3.2 \\
\hline & & $\mathrm{C}_{\mathrm{u}}$ & 116 & 91 \\
\hline & & $\mathrm{C}_{\mathrm{c}}$ & 0.57 & 1.7 \\
\hline $\begin{array}{c}\text { Water-release } \\
\text { (moisture retention) curve }\end{array}$ & $\frac{\text { MOSA }^{\underline{b}} \text { Chps. } 24 \text { and } 26}{\text { ASTM }^{a} \text { D 2325-65(94) }}$ & \multicolumn{3}{|c|}{ Results located in project files. } \\
\hline
\end{tabular}

a Annual Book of American Society for Testing and Materials (ASTM) Standards, Section 4, "Construction," Volume 04.08,

"Soil and Rock (1)," and Volume 04.09, "Soil and Rock (11)," 1996

${ }^{\mathrm{b}}$ Methods of Soil Analysis, 2nd Edition, Part 1, Soil Science Society of America, 1986

cvan Genuchten, M. 1980. "A Closed Form Equation for Predicting the Hydraulic Conductivity of Unsaturated Soils," Soil Science Society of America Journal, 44:892-898

Geotechnical samples collected from 6 to $8 \mathrm{ft}$ bgs

$\mathrm{mm}=$ Millimeter(s)

$\mathrm{d}_{50}=$ Median particle diameter

$\mathrm{Cu}=$ Uniformity coefficient, $\mathrm{Cu}=\mathrm{d}_{60} / \mathrm{d}_{10}$

$\mathrm{Cc}=$ Coefficient of curvature, $\mathrm{Cc}=\left(\mathrm{d}_{30}\right)^{2} /\left(\mathrm{d}_{10}\right)_{*}\left(\mathrm{~d}_{60}\right)$

Method used $=$ Wet sieve and Hydrometer

$\%=$ Percent

$\mathrm{g} / \mathrm{g}=$ Gram per gram

$\mathrm{cm}^{3}=$ Cubic centimeter

$\mathrm{g} / \mathrm{cm}^{3}=$ Gram(s) per cubic centimeter

Ksat $=$ Saturated permeability

$\mathrm{cm} / \mathrm{s}=$ Centimeter(s) per second

$\alpha$ and $\mathrm{N}=$ Calculated parameter

$\mathrm{cm}^{-1}=$ Unit(s) per centimeter

$\Theta r=$ Residual soil-water content

$\Theta s=$ Saturated soil-water content 
investigation samples are listed in Table A.2-1. Table A.11-1 lists the sample-specific analytical parameters.

\section{A.11.2.9 Analytes Detected Above Minimum Reporting Limits}

The analytical results detected at concentrations exceeding the correlated MRLs as established in the CAIP (NNSA/NV, 2002a) are summarized in the following sections. These results were compared to PALs (also established in the CAIP) and are a subset of those that exceed MRLs. All of the analytical results obtained through sample analysis are usable. A portion of the analytical results were rejected; however, these rejected data did not impact closure decisions as discussed in Section B.1.1.4 of Appendix B.

\section{A.11.2.9.1 Total Volatile Organic Compound Analytical Results for Soil Samples}

Total VOCs analytical results for soil samples exceeding the MRLs are shown on Table A.11-3. Results did not exceed the PALs.

Table A.11-3

Soil Sample Results for Total VOCs

Detected Above Minimum Reporting Limits at CAS 23-17-01

\begin{tabular}{|c|c|c|c|}
\hline \multirow{2}{*}{$\begin{array}{l}\text { Sample } \\
\text { Number }\end{array}$} & \multirow{2}{*}{$\begin{array}{l}\text { Sample } \\
\text { Location }\end{array}$} & \multirow{2}{*}{$\begin{array}{c}\text { Depth } \\
\text { (ft bgs) }\end{array}$} & Contaminants of Potential Concern $(\mu \mathrm{g} / \mathrm{kg})$ \\
\hline & & & Methylene Chloride \\
\hline \multicolumn{3}{|c|}{ Preliminary Action Levels ${ }^{a}$} & 21,000 \\
\hline 140J021 & \multirow{2}{*}{ J09 } & $9-10$ & $9.2(\mathrm{~J})$ \\
\hline 140J022 & & $14-15$ & $8.5(\mathrm{~J})$ \\
\hline
\end{tabular}

aBased on U.S. Environmental Protection Agency, Region 9 Preliminary Remediation Goals (PRGs) (EPA, 2000).

$\mathrm{ft}$ bgs $=$ Feet below ground surface $\mu \mathrm{g} / \mathrm{kg}=$ Micrograms per kilogram

$\mathrm{J}=$ Estimated value. Qualifier added to laboratory data; record accepted. Calibration verification did not meet criteria or was not performed.

\section{A.11.2.9.2 Total Semivolatile Organic Compound Analytical Results for Soil Samples}

Table A.11-4 presents the SVOCs results that exceeded the MRLs. Results did not exceed the PALs. 
Table A.11-4

Soil Sample Result for Total SVOCs

Detected Above Minimum Reporting Limits at CAS 23-17-01

\begin{tabular}{|c|c|c|c|}
\hline \multirow{2}{*}{$\begin{array}{l}\text { Sample } \\
\text { Number }\end{array}$} & \multirow{2}{*}{$\begin{array}{l}\text { Sample } \\
\text { Location }\end{array}$} & \multirow{2}{*}{$\begin{array}{l}\text { Depth } \\
\text { (ft bgs) }\end{array}$} & Contaminants of Potential Concern $(\mu \mathrm{g} / \mathrm{kg})$ \\
\hline & & & Diethyl Phthalate \\
\hline \multicolumn{3}{|c|}{ Preliminary Action Levels ${ }^{a}$} & $100,000,000$ \\
\hline 140J010 & $\mathrm{J} 05$ & $3-4$ & 560 \\
\hline
\end{tabular}

aBased on U.S. Environmental Protection Agency, Region 9 Preliminary Remediation Goals (PRGs) (EPA, 2000).

$\mathrm{ft}$ bgs $=$ Feet below ground surface

$\mu \mathrm{g} / \mathrm{kg}=$ Micrograms per kilogram

\section{A.11.2.9.3 Total Petroleum Hydrocarbon Analytical Results for Soil Samples}

Total Petroleum Hydrocarbons (DRO and GRO) analytical results for soil that exceed the MRLs are shown in Table A.11-5. The result that exceeds the PALs is listed in bold text. Sample 140J049 collected from location J20 at a depth of 9 to $10 \mathrm{ft} \mathrm{bgs} \mathrm{had} \mathrm{a} \mathrm{TPH} \mathrm{(DRO)} \mathrm{concentration} \mathrm{of} 320 \mathrm{ppm}$.

\section{A.11.2.9.4 Total RCRA Metals Results for Soil Samples}

Total RCRA metals were not detected in soil samples at concentrations exceeding PALs. Results exceeding the MRLs are shown in Table A.11-6.

\section{A.11.2.9.5 Ethylene Glycol}

No ethylene glycol analytical results for soil exceeded the MRLs.

\section{A.11.2.9.6 Polychlorinated Biphenyl Results for Soil Samples}

No PCB analytical results for soil exceeded the PALs. The single sample result exceeding the MRL is shown in Table A.11-7.

\section{A.11.2.9.7 Pesticides}

No pesticide analytical results for soil exceeded the PALs. Sample results exceeding the MRLs are shown in Table A.11-8. 
Table A.11-5

Soil Sample Results for TPH-DRO

Detected Above Minimum Reporting Limits at CAS 23-17-01

\begin{tabular}{|c|c|c|c|}
\hline \multirow{2}{*}{$\begin{array}{l}\text { Sample } \\
\text { Number }\end{array}$} & \multirow{2}{*}{$\begin{array}{l}\text { Sample } \\
\text { Location }\end{array}$} & \multirow{2}{*}{$\begin{array}{l}\text { Depth } \\
\text { (ft bgs) }\end{array}$} & \multirow{2}{*}{$\begin{array}{c}\text { Contaminants of Potential Concern }(\mathrm{mg} / \mathrm{kg}) \\
\text { Diesel-Range Organics }\end{array}$} \\
\hline & & & \\
\hline \multicolumn{3}{|c|}{ Preliminary Action Levels ${ }^{a}$} & 100 \\
\hline$\overline{140 J 015}$ & $\overline{\mathrm{J}} \mathrm{J08}$ & $\overline{0-1}$ & $85(\mathrm{~J})^{\mathrm{b}}$ \\
\hline 140J029 & $\mathrm{J} 16$ & $4-5$ & $26(J)^{b}$ \\
\hline 140J042 & $\mathrm{J} 12$ & $9-10$ & $8.8(J)^{b}$ \\
\hline 140J049 & \multirow{3}{*}{$\mathrm{J} 20$} & $9-10$ & $320(J)^{b}$ \\
\hline 140J050 & & $14-15$ & $5.8(J)^{b}$ \\
\hline 140J052 & & $4-5$ & $44(\mathrm{~J})^{\mathrm{C}}$ \\
\hline 140J054 & J21 & $4-5$ & $35(\mathrm{~J})^{\mathrm{c}}$ \\
\hline
\end{tabular}

${ }^{a}$ Nevada Administrative Code 445A.2272(b) (NAC, 2000).

${ }^{\mathrm{b}} \mathrm{Qualifier}$ added to laboratory data; record accepted. Total extractable petroleum hydrocarbons result quantitated from diesel standard calibration.

${ }^{\circ}$ Qualifier added to laboratory data; record accepted. Sample temperature exceeded and/or not documented. Total extractable petroleum hydrocarbons result quantitated from diesel standard calibration.

$\mathrm{ft}$ bgs $=$ Feet below ground surface

$\mathrm{mg} / \mathrm{kg}=$ Milligrams per kilogram

$\mathrm{J}=$ Estimated value

\section{A.11.2.9.8 Herbicides}

No herbicide analytical results for soil exceeded the MRLs.

\section{A.11.2.9.9 Tritium}

Tritium analytical results for soil did not exceed the MRLs.

\section{A.11.2.10 Contaminants of Concern}

Based on the aforementioned analytical results, TPH (DRO) was identified as a COC at location J20.

\section{A.11.3 Nature and Extent of COCs}

Total petroleum hydrocarbons (DRO) are located at J20 at a depth of 9 to $10 \mathrm{ft}$ bgs. A sample was sent to the laboratory from 14 to $15 \mathrm{ft}$ bgs from this borehole and no hydrocarbons were detected 
Table A.11-6

Soil Sample Results for Total RCRA Metals Detected Above Minimum Reporting Limits at CAS 23-17-01 (Page 1 of 2 )

\begin{tabular}{|c|c|c|c|c|c|c|c|c|c|}
\hline \multirow{2}{*}{$\begin{array}{l}\text { Sample } \\
\text { Number }\end{array}$} & \multirow{2}{*}{$\begin{array}{l}\text { Sample } \\
\text { Location }\end{array}$} & \multirow{2}{*}{$\begin{array}{c}\text { Depth } \\
\text { (ft bgs) }\end{array}$} & \multicolumn{7}{|c|}{ Contaminants of Potential Concern (mg/kg) } \\
\hline & & & Arsenic & Barium & Cadmium & Chromium & Lead & Selenium & Silver \\
\hline \multicolumn{3}{|c|}{ Preliminary Action Levels ${ }^{a}$} & 23 & 100,000 & 810 & 450 & 750 & 10,000 & 10,000 \\
\hline 140J001 & \multirow{2}{*}{$\mathrm{J} 01$} & $0-1$ & 8.9 & 110 & -- & 6.3 & 8 & -- & -- \\
\hline 140J002 & & $3-4$ & 7.2 & 93 & -- & 4.6 & 5.5 & -- & -- \\
\hline 140J003 & \multirow{2}{*}{$\mathrm{J} 02$} & $0-1$ & 8.5 & 72 & -- & 3.6 & 6.2 & -- & -- \\
\hline 140J004 & & $3-4$ & 7.6 & 94 & -- & 5.1 & 6.2 & -- & -- \\
\hline 140J005 & \multirow{2}{*}{$\mathrm{J} 03$} & $0-1$ & 12 & 75 & -- & 3.4 & 4.4 & -- & -- \\
\hline 140J006 & & $3-4$ & 9.4 & 70 & -- & 3.8 & 4.3 & -- & -- \\
\hline 140J007 & \multirow{2}{*}{$\mathrm{J} 04$} & $0-1$ & 8.6 & 67 & -- & 3.1 & 3.9 & -- & -- \\
\hline 140J008 & & $3-4$ & 7.8 & 63 & -- & 3.1 & 3.8 & -- & -- \\
\hline 140J009 & \multirow{2}{*}{ J05 } & $0-1$ & 9.7 & 80 & -- & 3.3 & 4.6 & -- & -- \\
\hline 140J010 & & $3-4$ & 8.9 & 62 & -- & 3.2 & 4.1 & -- & -- \\
\hline 140J011 & \multirow{2}{*}{ J06 } & $0-1$ & 8.9 & 73 & -- & 3.9 & 5.3 & -- & -- \\
\hline 140J012 & & $3-4$ & 8.6 & 70 & -- & 3.9 & 6.7 & -- & -- \\
\hline 140J013 & \multirow{2}{*}{$\mathrm{J} 07$} & $0-1$ & 7.9 & 68 & -- & 3.7 & 4.6 & -- & -- \\
\hline 140J014 & & $3-4$ & 7.8 & 78 & -- & 14 & 53 & -- & -- \\
\hline 140J015 & \multirow{2}{*}{ J08 } & $0-1$ & 9.4 & 72 & -- & 3.2 & 17 & -- & -- \\
\hline 140J016 & & $3-4$ & 7.8 & 81 & -- & 3.7 & 4.9 & -- & -- \\
\hline 140J017 & \multirow{3}{*}{ J10 } & $4-5$ & 10 & 72 & -- & $4.4(\mathrm{~J})^{\mathrm{b}}$ & 4.4 & -- & -- \\
\hline 140J018 & & $9-10$ & 5.7 & 48 & -- & $2.8(\mathrm{~J})^{\mathrm{b}}$ & 2.7 & -- & -- \\
\hline 140J019 & & $14-15$ & 6.1 & 46 & -- & $6.2(\mathrm{~J})^{\mathrm{b}}$ & 1.9 & -- & -- \\
\hline 140J020 & \multirow{3}{*}{ J09 } & $4-5$ & 7.9 & 68 & -- & $3.2(\mathrm{~J})^{\mathrm{b}}$ & 3.7 & -- & -- \\
\hline 140J021 & & $9-10$ & 5.9 & 50 & -- & $3.2(\mathrm{~J})^{\mathrm{b}}$ & 2.6 & -- & -- \\
\hline 140J022 & & $14-15$ & 4.5 & 55 & -- & $2.7(\mathrm{~J})^{\mathrm{b}}$ & 2.4 & -- & -- \\
\hline 140J023 & \multirow{3}{*}{ J18 } & $4-5$ & 7.1 & 60 & -- & $2.9(\mathrm{~J})^{\mathrm{b}}$ & 3.3 & -- & -- \\
\hline 140J024 & & $9-10$ & 8.1 & 52 & -- & $3.5(\mathrm{~J})^{\mathrm{b}}$ & 3.5 & -- & -- \\
\hline 140J025 & & $14-15$ & 7.9 & 69 & -- & $3.3(\mathrm{~J})^{\mathrm{b}}$ & 3.5 & -- & -- \\
\hline 140J026 & \multirow{3}{*}{ J17 } & $4-5$ & 6.6 & 59 & -- & $3.5(\mathrm{~J})^{\mathrm{b}}$ & 3.2 & -- & -- \\
\hline 140J027 & & $9-10$ & 7.4 & 57 & -- & $2.9(\mathrm{~J})^{\mathrm{b}}$ & 3.7 & -- & -- \\
\hline 140J028 & & $14-15$ & 6.6 & 59 & -- & $3.5(\mathrm{~J})^{\mathrm{b}}$ & 2.6 & -- & -- \\
\hline 140J029 & \multirow{3}{*}{ J16 } & $4-5$ & 7.6 & 66 & -- & $2.9(\mathrm{~J})^{\mathrm{b}}$ & 3.1 & -- & -- \\
\hline 140J030 & & $9-10$ & 7.4 & 44 & -- & $2.1(\mathrm{~J})^{\mathrm{b}}$ & 2.8 & -- & -- \\
\hline 140J031 & & $14-15$ & 6.5 & 67 & -- & $3.3(\mathrm{~J})^{\mathrm{b}}$ & 2.7 & -- & -- \\
\hline
\end{tabular}




\section{Table A.11-6 \\ Soil Sample Results for Total RCRA Metals \\ Detected Above Minimum Reporting Limits at CAS 23-17-01}

(Page 2 of 2)

\begin{tabular}{|c|c|c|c|c|c|c|c|c|c|}
\hline \multirow{2}{*}{$\begin{array}{l}\text { Sample } \\
\text { Number }\end{array}$} & \multirow{2}{*}{$\begin{array}{l}\text { Sample } \\
\text { Location }\end{array}$} & \multirow{2}{*}{$\begin{array}{l}\text { Depth } \\
\text { (ft bgs) }\end{array}$} & \multicolumn{7}{|c|}{ Contaminants of Potential Concern $(\mathrm{mg} / \mathrm{kg})$} \\
\hline & & & Arsenic & Barium & Cadmium & Chromium & Lead & Selenium & Silver \\
\hline \multicolumn{3}{|c|}{ Preliminary Action Levels ${ }^{a}$} & 23 & 100,000 & 810 & 450 & 750 & 10,000 & 10,000 \\
\hline 140J032 & \multirow{4}{*}{ J15 } & $4-5$ & 8 & 60 & -- & 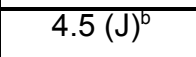 & 4.9 & -- & $11(\mathrm{~J})^{\mathrm{C}}$ \\
\hline $\begin{array}{c}\text { 140J032RR } \\
1\end{array}$ & & $4-5$ & -- & -- & -- & -- & -- & -- & $2.3(J)^{d}$ \\
\hline 140J033 & & $9-10$ & 6.7 & 46 & -- & $2.3(\mathrm{~J})^{\mathrm{b}}$ & 3 & -- & -- \\
\hline 140J034 & & $14-15$ & 8 & 45 & -- & $2.6(J)^{b}$ & 2.6 & -- & -- \\
\hline 140J035 & \multirow{3}{*}{ J14 } & $4-5$ & 7.9 & 52 & -- & $3.7(\mathrm{~J})^{\mathrm{b}}$ & 3.4 & -- & -- \\
\hline 140J036 & & $9-10$ & 9.2 & 53 & -- & $3.2(\mathrm{~J})^{\mathrm{b}}$ & 3.1 & -- & -- \\
\hline 140J037 & & $14-15$ & 11 & 54 & -- & $3(J)^{b}$ & 2.3 & -- & -- \\
\hline 140J038 & \multirow{3}{*}{$\mathrm{J} 13$} & $4-5$ & 5.2 & 1,400 & 100 & $19(\mathrm{~J})^{\mathrm{b}}$ & 32 & 3 & -- \\
\hline 140J039 & & $9-10$ & 8.1 & 61 & -- & $3.3(\mathrm{~J})^{\mathrm{b}}$ & 3.8 & -- & -- \\
\hline 140J040 & & $14-15$ & 12 & 53 & -- & $2.7(\mathrm{~J})^{\mathrm{b}}$ & 3.2 & -- & -- \\
\hline 140J041 & \multirow{3}{*}{ J12 } & $4-5$ & 8 & 48 & -- & $4.2(\mathrm{~J})^{\mathrm{b}}$ & 3 & $\begin{array}{l}- \\
\end{array}$ & -- \\
\hline 140J042 & & $9-10$ & 7.9 & 40 & -- & $3.4(J)^{b}$ & 2.8 & -- & -- \\
\hline 140J043 & & $14-15$ & 7.2 & 67 & -- & $3.8(\mathrm{~J})^{\mathrm{b}}$ & 3.2 & -- & -- \\
\hline 140J044 & \multirow{3}{*}{$\mathrm{J} 11$} & $4-5$ & 9.3 & 51 & -- & $4.7(\mathrm{~J})^{\mathrm{b}}$ & 3.7 & -- & -- \\
\hline 140J045 & & $9-10$ & 7.6 & 43 & -- & $2.2(\mathrm{~J})^{\mathrm{b}}$ & 2.4 & -- & -- \\
\hline 140J046 & & $14-15$ & 8 & 61 & -- & $2.7(\mathrm{~J})^{\mathrm{b}}$ & 2.9 & -- & -- \\
\hline 140J047 & \multirow{2}{*}{ J19 } & $9-10$ & 8.7 & 47 & -- & $3.2(J)^{b}$ & 3.2 & -- & -- \\
\hline 140J048 & & $14-15$ & 8.6 & 49 & -- & $2.7(\mathrm{~J})^{\mathrm{b}}$ & 2.7 & -- & -- \\
\hline 140J049 & \multirow{2}{*}{ J20 } & $9-10$ & 9.3 & 37 & -- & $3.4(\mathrm{~J})^{\mathrm{b}}$ & 3.2 & -- & -- \\
\hline 140J050 & & $14-15$ & 7.7 & 62 & -- & $3.3(\mathrm{~J})^{\mathrm{b}}$ & 2.9 & -- & -- \\
\hline 140J302 & $\mathrm{J} 03$ & $0-1$ & 10 & 68 & -- & 3.6 & 4.8 & -- & -- \\
\hline 140J307 & J17 & $14-15$ & 7.3 & 55 & -- & $3.1(\mathrm{~J})^{\mathrm{b}}$ & 3.1 & -- & -- \\
\hline 140J314 & J14 & $14-15$ & 11 & 58 & -- & $3.1(\mathrm{~J})^{\mathrm{b}}$ & 2.7 & -- & -- \\
\hline
\end{tabular}

aBased on U.S. Environmental Protection Agency, Region 9 Preliminary Remediation Goals (PRGs) (EPA, 2000). Arsenic is the mean plus two times the standard deviation of the mean for sediment samples collected by the NBMG throughout NTTR (NBMG, 1998; Moore, 1999)

${ }^{b}$ Qualifier added to laboratory data; record accepted. Serial dilution \%D outside of control limits. Matrix effects may exist.

'Qualifier added to laboratory data; record accepted. Matrix spike recovery grossly outside of control limits. Duplicate precision analysis (relative percent difference) outside of control limits.

$\mathrm{ft}$ bgs $=$ Feet below ground surface

$\mathrm{mg} / \mathrm{kg}=$ Milligrams per kilogram

$--=$ Not detected above minimum reporting limit

$\mathrm{J}=$ Estimated value 
Table A.11-7

Soil Sample Result for PCBs Detected

Above Minimum Reporting Limits at CAS 23-17-01

\begin{tabular}{|c|c|c|c||}
\hline \multirow{2}{*}{$\begin{array}{c}\text { Sample } \\
\text { Number }\end{array}$} & \multirow{2}{*}{$\begin{array}{c}\text { Sample } \\
\text { Location }\end{array}$} & $\begin{array}{c}\text { Depth } \\
\text { (ft bgs) }\end{array}$ & Contaminants of Potential Concern $(\mu \mathbf{g} / \mathbf{k g})$ \\
\cline { 3 - 4 } & & & Aroclor-1260 \\
\hline \multicolumn{2}{|c|}{ Preliminary Action Levels } & $\mathbf{1 , 0 0 0}$ \\
\hline \hline 140J001 & $\mathrm{J} 01$ & $0-1$ & 61 \\
\hline
\end{tabular}

aBased on U.S. Environmental Protection Agency, Region 9 Preliminary Remediation Goals (PRGs) (EPA, 2000).

$\mathrm{ft}$ bgs $=$ Feet below ground surface

$\mu \mathrm{g} / \mathrm{kg}=$ Micrograms per kilogram

above PALs. During step-out sampling, another borehole was drilled just next to J20 and samples were sent to the laboratory from 0 to $1 \mathrm{ft}$ and 4 to $5 \mathrm{ft}$ bgs. Diesel-range organics were not detected at these horizons at concentrations exceeding the PAL. Step-out sampling was conducted $15 \mathrm{ft}$ laterally from $\mathbf{J} 20$ at locations $\mathbf{J} 21, \mathrm{~J} 22$, and $\mathbf{J} 23$. These three boreholes were sampled and analyzed from 0 to 1,4 to 5, 9 to 10 , and 14 to $15 \mathrm{ft}$ bgs. Total petroleum hydrocarbons (DRO) was not detected at these horizons at concentrations exceeding the PALs.

\section{A.11.4 Revised Conceptual Site Model}

No variations to the CSM were identified. 
Table A.11-8

Soil Sample Results for Pesticides Detected Above Minimum Reporting Limits at CAS 23-17-01

\begin{tabular}{|c|c|c|c|c|c|c|}
\hline \multirow{2}{*}{$\begin{array}{l}\text { Sample } \\
\text { Number }\end{array}$} & \multirow{2}{*}{$\begin{array}{c}\text { Sample } \\
\text { Location }\end{array}$} & \multirow{2}{*}{$\begin{array}{l}\text { Depth } \\
\text { (ft bgs) }\end{array}$} & \multicolumn{4}{|c|}{ Contaminants of Potential Concern $(\mu \mathrm{g} / \mathrm{kg})$} \\
\hline & & & 4,4'-DDE & 4,4'-DDT & Alpha-Chlordane & Gamma-Chlordane \\
\hline \multicolumn{3}{|c|}{ Preliminary Action Levels $^{a}$} & 12,000 & 12,000 & NI & NI \\
\hline 140J002 & J01 & $3-4$ & -- & -- & $13(\mathrm{~J})^{\mathrm{b}}$ & 7.9 \\
\hline 140J003 & $\mathrm{J} 02$ & $0-1$ & -- & -- & $12(\mathrm{~J})^{\mathrm{b}}$ & 7.3 \\
\hline 140J005 & \multirow{2}{*}{$\mathrm{J} 03$} & $0-1$ & -- & -- & $6.8(\mathrm{~J})^{\mathrm{b}}$ & 2.7 \\
\hline 140J006 & & $3-4$ & -- & -- & $5.4(\mathrm{~J})^{\mathrm{b}}$ & -- \\
\hline 140J008 & J04 & $3-4$ & -- & -- & $3.7(\mathrm{~J})^{\mathrm{b}}$ & 2.1 \\
\hline 140J011 & \multirow{2}{*}{ J06 } & $0-1$ & -- & -- & $2.1(\mathrm{~J})^{\mathrm{b}}$ & -- \\
\hline 140J012 & & $3-4$ & -- & -- & $2.9(\mathrm{~J})^{\mathrm{b}}$ & -- \\
\hline 140J013 & \multirow{2}{*}{$\mathrm{J} 07$} & $0-1$ & -- & 4.3 & $14(\mathrm{~J})^{\mathrm{b}}$ & 8 \\
\hline 140J014 & & $3-4$ & -- & 9.2 & $15(\mathrm{~J})^{\mathrm{b}}$ & 8 \\
\hline 140J015 & \multirow{3}{*}{$\mathrm{J} 08$} & $0-1$ & $15(\mathrm{~J})^{b}$ & 26 & -- & -- \\
\hline 140J015RR1 & & $0-1$ & -- & -- & $240(J)^{b}$ & $170(J)^{c}$ \\
\hline 140J016 & & $3-4$ & -- & -- & $2(J)^{b}$ & -- \\
\hline 140J026 & $\mathrm{J} 17$ & $4-5$ & -- & -- & $11(\mathrm{~J})^{\mathrm{b}}$ & 5.2 \\
\hline 140J032 & J15 & $4-5$ & -- & -- & $3(J)^{b}$ & -- \\
\hline 140J035 & $\mathrm{J} 14$ & $4-5$ & -- & -- & $2.1(\mathrm{~J})^{b}$ & -- \\
\hline 140J047 & J19 & $9-10$ & -- & -- & $3.4(J)^{b}$ & 2 \\
\hline 140J049 & $\mathrm{J} 20$ & $9-10$ & -- & $16(\mathrm{~J})^{\mathrm{d}}$ & $3.9(J)^{b}$ & $9.7(\mathrm{~J})^{\mathrm{b}}$ \\
\hline 140J302 & $\mathrm{J03}$ & $0-1$ & -- & -- & $6.1(\mathrm{~J})^{\mathrm{b}}$ & 2.4 \\
\hline
\end{tabular}

aBased on U.S. Environmental Protection Agency, Region 9 Preliminary Remediation Goals (PRGs) (EPA, 2000).

${ }^{b}$ Qualifier added to laboratory data; record accepted. \%D between columns $>25$.

${ }^{c} Q$ ualifier added to laboratory data; record accepted. \%D between columns $>25$. Surrogates diluted out.

${ }^{\mathrm{d}}$ Qualifier added to laboratory data; record accepted. Calibration verification did not meet criteria or was not performed.

$\mathrm{ft}$ bgs = Feet below ground surface

$\mu \mathrm{g} / \mathrm{kg}=$ Micrograms per kilogram

$\mathrm{J}=$ Estimated value

-- $=$ Not detected 


\section{A.12.0 Waste Management}

\section{A.12.1 Waste Minimization}

Corrective Action Unit 140 integrated waste minimization into the field activities. Investigationderived waste was segregated to the greatest extent possible. Controls were in place to minimize the use of hazardous materials and unnecessary generation of hazardous and/or mixed waste.

Decontamination activities were planned and executed to minimize the volume of rinsate generated.

Potentially hazardous waste generated during the investigation was placed in 55-gallon (gal) steel drums and labeled as "Hazardous Waste-Pending Analysis." One Hazardous Waste Accumulation Area (HWAA) and two Satellite Accumulation Areas (SAAs) were established to manage the waste at the investigation areas. The amount, type, and source of waste placed into each drum were recorded in waste management log books at each location.

\section{A.12.1.1 Characterization}

Analytical results of associated samples and process knowledge for each drum was reviewed to ensure compliance with federal regulations, state regulations, DOE directives/policies, guidance, waste disposal criteria, and Shaw Environmental, Inc. (Shaw) Standard Quality Practices. Analytical data was reviewed through Tier I, II, and III validation.

\section{A.12.1.2 Waste Streams}

Newly generated IDW was segregated into the following waste streams:

- Personal protective equipment (PPE), disposable sampling equipment, and debris including, but not limited to: plastic sheeting, glass/plastic sample jars, PPE, soil, wood, sampling scoops, aluminum foil, bowls, etc.

- Decontamination rinsate

- Debris from use of Royal Demolition Explosive (RDX) test kit 


\section{A.12.2 Investigation-Derived Waste Generated}

Ten containers of waste were generated during the investigation:

- Eight drums were characterized as sanitary waste and recommended for disposal at the NTSpermitted sanitary facilities. These drums were generated at CASs 05-19-01 and 23-17-01.

- Plastic decontamination pad liners will be disposed of as sanitary waste at the NTS Industrial Landfill at Area 9.

- One drum contains debris from the use of the RDX test kit at CASs 05-08-01, 05-17-01, and 05-23-01. This drum is currently managed as an SAA and will be disposed of as hazardous waste.

\section{A.12.2.1 Waste Management Samples}

Waste management samples were not collected from drummed waste. 


\section{A.13.0 Quality Assurance}

This section contains a summary of the QA/QC process implemented during the sampling and analysis activities conducted in support of the CAU 140 corrective action investigation. Laboratory analyses were conducted for samples used in the decision-making process to provide a quantitative measurement of any COPCs present. Rigorous QA/QC was implemented for all laboratory samples including documentation, verification, and validation of analytical results, and affirmation of DQI requirements related to laboratory analyses. Detailed information regarding the QA program is contained in the Industrial Sites QAPP (NNSA/NV, 2002b). A discussion of the DQIs, including the datasets, is provided in Appendix B.

\section{A.13.1 Data Validation}

Data validation was performed in accordance with the Industrial Sites QAPP (NNSA/NV, 2002b) and approved protocols and procedures. All laboratory data from samples collected and analyzed for CAU 140 were evaluated for data quality according to the EPA Functional Guidelines (EPA, 1994b and 1999). These guidelines are implemented in a tiered process and are presented in Sections A.12.1.1 through A.12.1.3. Data were reviewed to ensure that samples were appropriately processed and analyzed, and the results passed data validation criteria. Documentation of the data qualifications resulting from these reviews is retained in project files as a hard copy and electronic media.

One hundred percent of the data generated as part of this investigation were subjected to Tier I and Tier II evaluations as defined below. A Tier III evaluation was performed on six percent of the data generated.

\section{A.13.1.1 Tier I Evaluation}

Tier I evaluation for chemical and radiological analyses examines but was not limited to:

- Sample count/type consistent with chain of custody

- Analysis count/type consistent with chain of custody

- Correct sample matrix

- Significant problems stated in the cover letter or case narrative 
- Completeness of certificates of analysis

- Completeness of Contract Laboratory Program (CLP) or CLP-like packages

- Completeness of signatures, dates, and times on chain of custody

- Condition-upon-receipt variance form included

- Requested analyses performed on all samples

- Date received/analyzed given for each sample

- Correct concentration units indicated

- Electronic data transfer supplied

- Results reported for field and laboratory QC samples

- Whether or not the deliverable met the overall objectives of the project

- Proper field documentation accompanies project packages

\section{A.13.1.2 Tier II Evaluation}

Tier II evaluation for chemical and radiological analyses examined, but was not limited to, the following.

\section{Chemical:}

- Correct detection limits achieved

- Sample date, preparation date, and analysis date for each sample

- Holding time criteria met

- QC batch association for each sample

- Cooler temperature upon receipt

- Sample $\mathrm{pH}$ for aqueous samples, as required

- Detection limits properly adjusted for dilution, as required

- Blank contamination evaluated and applied to sample results/qualifiers

- Matrix spike/matrix spike duplicate, percent recovery $(\% \mathrm{R})$, and relative percent difference (RPDs) evaluated and applied to laboratory results/qualifiers

- Field duplicate RPDs evaluated using professional judgement and applied to laboratory results/qualifiers

- Laboratory duplicate RPDs evaluated and applied to laboratory results/qualifiers 
- Surrogate \%Rs evaluated and applied to laboratory results/qualifiers

- Laboratory control sample \%R evaluated and applied to laboratory results/qualifiers

- Initial and continuing calibration evaluated and applied to laboratory results/qualifiers

- Internal standard evaluated and applied to laboratory results/qualifiers

- Mass spectrometer tuning criteria

- Organic compound quantitation

- Inductively coupled plasma (ICP) interference check sample evaluation

- Graphite furnace atomic absorption quality control

- ICP serial dilution effects

- Recalculation of 10 percent of laboratory results from raw data

\section{Radioanalytical:}

- Correct detection limits achieved

- Blank contamination evaluated and, if significant, qualifiers are applied to sample results

- Certificate of Analysis consistent with data package documentation

- Quality control sample results (duplicates, laboratory control samples, laboratory blanks) evaluated and used to determine laboratory result qualifiers

- Sample results, uncertainty, and minimum detectable concentration evaluated

- Detector system calibrated to National Institute for Standards and Technology (NIST)-traceable sources

- Calibration sources preparation was documented, demonstrating proper preparation and appropriateness for sample matrix, emission energies, and concentrations

- Detector system response to daily, weekly, and monthly background and calibration checks for peak energy, peak centroid, peak full-width half-maximum, and peak efficiency, depending on the detection system

- Tracers NIST-traceable, appropriate for the analysis performed, and recoveries that met QC requirements 
- Documentation of all QC sample preparation complete and properly performed

- Spectra lines, photon emissions, particle energies, peak areas, and background peak areas support the identified radionuclide and its concentration

- Recalculation of 10 percent of laboratory results from raw data

\section{A.13.1.3 Tier III Review}

The Tier III review is an independent examination of the Tier II evaluation. The Tier III review independently duplicates the Tier II review for a limited number of samples (typically 5 percent) and includes the following additional evaluations.

\section{Chemical:}

- Recalculation of laboratory results from raw data

\section{Radioanalytical:}

- QC sample results (e.g., calibration source concentration, percent recovery, and RDP) verified

- Radionuclides and their concentration validated, as appropriate, considering their decay schemes, half-lives, and process knowledge of the site

- Each identified line in spectra verified against emission libraries and calibration results

- Independent identification of spectra lines, area under the peaks, and quantification of radionuclide concentration in a random number of sample results

- Recalculation of 10 percent of the laboratory results from raw data

A Tier III review of approximately ten percent of the samples was conducted by TechLaw, Inc. in Lakewood, Colorado. Tier II and Tier III results were compared and where differences were noted, data were reviewed, and changes made accordingly.

\section{A.13.2 Quality Control Samples}

There were 15 trip blanks, 4 field blanks, 3 source blanks for disposable sampling equipment, 2 equipment rinsate blanks, 3 matrix spike/matrix spike duplicates (MS/MSDs), and 5 field duplicates collected and submitted for analysis by laboratory analytical methods as shown in Table A.2-1. The 
quality control samples were assigned individual sample numbers and sent to the laboratory "blind." Additional samples were selected by the laboratory to be analyzed as laboratory duplicates.

\section{A.13.2.1 Field Quality Control Samples}

Review of the field-blank analytical data for the CAU 140 soil sampling indicates that cross-contamination from field methods did not occur during sample collection. Field, equipment rinsate, and source blanks were analyzed for the applicable parameters listed in Table A.2-1 and trip blanks were analyzed for VOCs only. No contaminants were detected in samples above the contract-required detection limits.

During the sampling events, five field duplicate soil samples were sent as blind samples to the laboratory to be analyzed for the CAS-specific parameters listed in Table A.2-1. For these samples, the duplicate results precision (i.e., RPDs between the environmental sample results and their corresponding field duplicate sample results) were evaluated to the guidelines set forth in EPA Functional Guidelines (EPA, 1994b). Two sample pairs contained analytes that were greater than the allowable RPD.

\section{A.13.2.2 Laboratory Quality Control Samples}

Analysis of method QC blanks were performed on each sample delivery group (SDG) for inorganics. Analysis for surrogate spikes and preparation blanks (PBs) were performed on each SDG for organics only. Initial and continuing calibration and laboratory control samples (LCS) were performed for each SDG by Paragon Analytical. The results of these analyses were used to qualify associated environmental sample results according to EPA Functional Guidelines (EPA, 1994b and 1999). Documentation of data qualifications resulting from the application of these guidelines is retained in project files as both hard copy and electronic format.

The laboratory included a PB, LCS, and a laboratory duplicate sample with each batch of field samples analyzed for radionuclides.

\section{A.13.3 Field Nonconformances}

There were no field nonconformances identified for the corrective action investigation. 


\section{A.13.4 Laboratory Nonconformances}

Laboratory nonconformances are due to inconsistencies in analytical instrumentation operation, sample preparations, extractions, missed holding times, and fluctuations in internal standard and calibration results. Fourteen nonconformances were issued by the laboratory that resulted in qualifying data and have been accounted for during the data qualification process. 


\section{A.14.0 Summary}

Analytes detected in soil samples during the corrective action investigation were evaluated against PALs to determine the nature and extent of contaminants of concern for CAU 140. Assessment of the data generated from corrective action investigation activities indicates the PALs were exceeded in soil samples at CAU 140 as specified in the CAIP. The following summarizes the results for each CAS where COCs were detected or at the Gravel Gertie, where COCs are assumed to be present.

CAS 05-08-01 - The COCs lead and the radioisotopes Th-234, U-238, and U-235 were found in surface soils at location A05. The lead concentration decreased with depth, to a concentration below PALs at 2 to $3 \mathrm{ft}$ bgs. The U-238 and U-235 concentrations decreased with depth and were below PALs at 2 to $3 \mathrm{ft}$ bgs. The Th-234 concentration decreased with depth but was still above PALs at 2 to $3 \mathrm{ft} \mathrm{bgs}$; however, the concentration decreased by an order of magnitude within the 2-ft interval. Based on the decrease in concentrations with depth, the Th-234 concentration is expected to be below PALs at a depth of $4 \mathrm{ft}$ bgs. Sample results from the step-out locations (A06, A07, and A08) indicate lead and radioisotope concentrations have not migrated more than $5 \mathrm{ft}$ laterally at concentrations that exceed the PALs.

CAS 05-23-01 - No COCs were identified in the soil at this CAS. Due to the physical constraints of the structure, it is not practical to collect samples from inside the Gravel Gertie. Historical radiological surveys and air monitoring of the Gravel Gertie experiments that have used uranium as a tracer material, have not identified significant levels of external (to the structure) contamination. Based on the historical documentation, the Gravel Gertie internal structure is considered to be contaminated.

CAS 23-17-01 - Total petroleum hydrocarbons (DRO) were identified at sample location $\mathrm{J} 20$ at a depth of 9 to $10 \mathrm{ft}$ bgs. Samples were collected from 0 to $1 \mathrm{ft}, 4$ to $5 \mathrm{ft}$, and 14 to $15 \mathrm{ft}$ bgs from this borehole and no hydrocarbons were detected above PALs. Step-out sampling was conducted out $15 \mathrm{ft}$ laterally from $\mathrm{J} 20$ at locations $\mathrm{J} 21, \mathrm{~J} 22$, and $\mathrm{J} 23$. These three boreholes were sampled and analyzed from 0 to 1,4 to 5, 9 to 10 , and 14 to $15 \mathrm{ft}$ depth. No TPH (DRO) were found in any of these step-outs; therefore, the extent of DRO-impacted soil has been determined. 


\section{A.15.0 References}

ASTM, see American Society for Testing and Materials.

Alderson, S., Shaw Environmental, Inc. 2002. Surface Radiological Survey of CAU 140. Las Vegas, NV.

American Society for Testing and Materials. 1996. Section 04.08 and 04.09, "Soil and Rock, and Construction." In the Annual Book of ASTM Standards. Philadelphia, PA.

American Society for Testing and Materials. 2000a. Standard Test Method for Radiochemical Determination of Plutonium in Soil by Alpha Spectroscopy, ASTM C 1001-90.

West Conshohocken, PA.

American Society for Testing and Materials. 2000b. Standard Test Method for Radiochemical Determination of Uranium in Soil by Alpha Spectroscopy, ASTM C 1000-00.

West Conshohocken, PA.

American Society for Testing and Materials. 2000c. Standard Test Method for Strontium-90 in Water, ASTM D 5811-00. West Conshohocken, PA.

American Society for Testing and Materials. 2002a. Standard Test Method for Isotopic Uranium in Water by Radiochemistry, ASTM D 3972-02. West Conshohocken, PA.

American Society for Testing and Materials. 2002b. Standard Test Method for Plutonium in Water, ASTM D 3865-02. West Conshohocken, PA.

CFR, see Code of Federal Regulations.

Code of Federal Regulations. 2002a. Title 40 CFR Part 141.66, "Maximum Contaminant Levels for Radionuclides." Washington, DC: U.S. Government Printing Office.

DOE/NV, see U.S. Department of Energy, Nevada Operations Office.

EPA, see U.S. Environmental Protection Agency.

FFACO, see Federal Facility Agreement and Consent Order.

Federal Facility Agreement and Consent Order. 1996 (as amended). Agreed to by the State of Nevada, the U.S. Department of Energy, and the U.S. Department of Defense.

Frazier, A.R., Reynolds Electrical \& Engineering Co., Inc. 1988. Letter entitled, "Revised Nevada Test Site Sanitary Landfill Operation and Maintenance Plan,” 29 July. Las Vegas, NV. 
IT, see IT Corporation.

IT Corporation. 2001. "Preliminary Assessment Conditions Forms for CAU/CAS Numbers: 140/05-08-01; 140/05-08-02; 140/05-17-01; 140/05-19-01; 140/05-23-01; 140/05-35-01; 140/05-99-04; 140/22-99-04," 25 September. Las Vegas NV.

IT Corporation. 2002. Site-Specific Health and Safety Plan for CAU 140, Waste Dumps, Burn Pits, and Storage Area, Nevada Test Site, Nevada, Rev. 1, November. Las Vegas, NV.

McArthur, R.D., and S.W. Mead. 1989. Radiation Inventory and Distribution Program: Report No. 5, Areas 5, 11, 12, 15, 17, 18, 19, 25, 26, and 30, DOE/NV/10384-26, Publication No. 45067. Las Vegas, NV: Desert Research Institute.

McArthur, R.D., and F.L. Miller, Jr. 1989. Off-Site Radiation Exposure Review Project, Phase II Soil Program, DOE/NV/10384--23. Las Vegas, NV: Desert Research Institute.

Metcalf, J., Sandia National Laboratories. 2002. Record of telecon with A. Dudley (Science Applications International Corporation) regarding CAU 140, CAS 05-23-01, 6 March. Las Vegas, NV: ITLV.

Moore, J., Science Applications International Corporation. 1999. Memorandum to M. Todd (SAIC), "Background Concentrations for NTS and TTR Soil Samples," 3 February. Las Vegas, NV: IT Corporation.

NAC, see Nevada Administrative Code.

NBMG, see Nevada Bureau of Mines and Geology.

NCRP, see National Council on Radiation Protection and Measurements.

NDEP, see Nevada Division of Environmental Protection.

NIOSH, see National Institute for Occupational Safety and Health.

NNSA/NV, see U.S. Department of Energy, National Nuclear Security Administration Nevada Operations Office.

Nevada Administrative Code. 2000. NAC 445A.2272, "Contamination of Soil: Establishment of Action Levels." Carson City, NV.

Nevada Bureau of Mines and Geology. 1998. Mineral and Energy Resource Assessment of the Nellis Air Force Range, Open-File Report 98-1. Reno, NV. 
Norvell, D., Bechtel Nevada. 2001. Record of meeting with A. Dudley (Science Applications International Corporation) regarding Area 23 Landfills, 9 October. Las Vegas, NV: IT Corporation.

REECo, see Reynolds Electrical \& Engineering Co., Inc.

RSN, see Raytheon Services Nevada.

Raytheon Services Nevada. 1992. Engineering drawing JS-023-002-C2 entitled, "Nevada Test Site Area 23 Mercury - Facilities Map," 23 December. Las Vegas, NV.

Reynolds Electrical \& Engineering Co., Inc. 1993. Survey as-built engineering drawing 23-ML-556-C2.1 entitled, "Nevada Test Site - Area 23 Closure Design, Hazardous Waste Trenches, Mercury Landfill Site Grading Plan/Sections," 4 March. Las Vegas, NV.

SAIC, see Science Applications International Corporation.

Sandia Corporation. 1964. Measurements from Gravel Gertie Tests, July, SC-R-64-127. Albuquerque, NM.

Science Applications International Corporation. 2002. Surface Geophysical Survey Final Report Industrial Sites Project-CAU 140 Nevada Test Site, May. Harrisburg, PA.

Soil Science Society of America. 1986. "Methods of Soil Analysis," 2nd Edition, Part 1. Madison, WI.

Soil Science Society of America Journal. 1980. "A Closed Form Equation for Predicting the Hydraulic Conductivity of Unsaturated Soils."

USGS, see U.S. Geological Survey.

U.S. Department of Energy. 1997. Environmental Measurements Laboratory Procedures Manual, HASL-300, 28th Ed., Vol. I. New York, NY.

U.S. Department of Energy, Nevada Operations Office. 1996b. Nevada Test Site Water-Supply Wells, DOE/NV/10845-56, Publication No. 45138. Prepared by E.D. Gillespie, D. Donithan, and P. Seaber. Las Vegas, NV: Desert Research Institute.

U.S. Department of Energy, Nevada Operations Office. 1999. Corrective Action Investigation Plan for Corrective Action Unit 98: Frenchman Flat, Nevada Test site, Nevada, DOE/NV--478, Rev. 1. Las Vegas, NV.

U.S. Department of Energy, National Nuclear Security Administration Nevada Operations Office. 2002a. Corrective Action Investigation Plan for Corrective Action Unit 140: Waste Dumps, Burn Pits, and Storage Area, Nevada Test Site, Nevada, DOE/NV--826, July. Las Vegas, NV. 
U.S. Department of Energy, National Nuclear Security Administration Nevada Operations Office. 20002b. Industrial Sites Quality Assurance Project Plan, Nevada Test Site, Nevada, Rev. 3, DOE/NV--372. Las Vegas, NV.

US Ecology and Atlan-Tech. 1992. Environmental Monitoring Report for the Proposed Ward Valley, California, Low-Level Radioactive Waste (LLRW) Facility. Auburn, CA.

U.S. Environmental Protection Agency. 1980. Prescribed Procedures for Measurement of Radioactivity in Drinking Water, EPA 600/4-80-032 (NTIS/PB80-224744; CD ROM; NEPIS/http://www.epa.gov/cincl). Washington, DC.

U.S. Environmental Protection Agency. 1994a. Guidance for the Data Quality Objectives Process, EPA QA/G-4. Washington, DC.

U.S. Environmental Protection Agency. 1994b. Contract Laboratory Program National Functional Guidelines for Inorganic Data Review, EPA 540/R-94/013. Washington, DC.

U.S. Environmental Protection Agency. 1996. Test Methods for Evaluating Solid Waste, Physical/Chemical Methods, SW-846, CD ROM PB97-501928GEI, which contains updates for 1986, 1992, 1994, and 1996. Washington, DC.

U.S. Environmental Protection Agency. 1999. Contract Laboratory Program National Functional Guidelines for Organic Data Review, EPA 540/R-99/008. Washington, DC.

U.S. Environmental Protection Agency. 2000. Memo from S.J. Smucker to PRG Table Mailing List regarding Region IX Preliminary Remediation Goals (PRGs), 1 November. San Francisco, CA.

U.S. Geological Survey. 1962. Selected Logs and Drilling Records of Wells and Test Holes Drilled at the Nevada Test Site Prior to 1960, TEI-804, January. Prepared by J.E. Moore. Denver, CO.

U.S. Geological Survey. 1964. Summary of Hydraulic Data, Quality of Water, and Lithologic Log for Army Well 1, Mercury Valley, Nye County, Nevada, Technical Letter NTS-71, 15 January. Prepared by G.L. Meyer, and R.E. Smith. Denver, CO.

U.S. Geological Survey. 1996. Summary of Hydrogeological Controls on Ground-Water Flow at the Nevada Test Site, Nye County, Nevada, USGS-WRIR-96-4109. Prepared by R.L. Laczniak, J.C. Cole, D.A. Sawyer, and D.A. Trudeau. Carson City, NV.

Williams, K., Bechtel Nevada. 1998. Record of meeting with J. Markowsky (Science Applications International Corporation), regarding the Area 23 Hazardous Waste Storage Area, 29 January. Las Vegas, NV: ITLV. 
Appendix B

Data Assessment for CAU 140 


\section{B.1.0 Data Assessment}

This appendix provides an assessment of CAU 140 investigation results to determine whether the data collected met the DQOs and can support their intended use in the decision-making process. This assessment includes a reconciliation of the data with the general CSM established for this project.

\section{B.1.1 Statement of Usability}

This section provides an evaluation of the DQIs in determining the degree of acceptability or usability of the reported data for the decision-making process.

\section{B.1.1.1 Precision}

Precision is a measure of agreement among a replicate set of measurements of the same property under similar conditions. This agreement is expressed as the RPD between duplicate measurements (EPA, 1996). The RPD is determined by dividing the difference between the replicate measurement values by the average measurement value and multiplying the result by 100 , or:

$$
\operatorname{RPD}=\left|\left\{\left(\mathrm{a}_{1}-\mathrm{a}_{2}\right) /\left[\left(\mathrm{a}_{1}+\mathrm{a}_{2}\right) / 2\right]\right\} \times 100\right|
$$

where

$\mathrm{a}_{1} \quad=$ Sample value

$\mathrm{a}_{2} \quad=$ Duplicate sample value

Determinations of precision can be made for field sample duplicates, laboratory duplicates, or both. Field sample duplicates are collected simultaneously with a sample from the same source under similar conditions in separate containers. The duplicate sample is treated independently of the original sample in order to assess field impacts and laboratory performance on precision through a comparison of results. Laboratory precision is evaluated as part of the required laboratory internal QC program to assess performance of analytical procedures. The laboratory sample duplicates are an aliquot or subset of a field sample generated in the laboratory. They are not a separate sample but portions of an existing sample. Typically, other laboratory duplicate QC samples include MSD and laboratory control sample duplicate (LCSD) samples. 
The variability in the results from the analysis of field sample duplicates is generally greater than the variability in the results of laboratory duplicates (LDs). This higher variability for field sample duplicates results from the increased potential to introduce factors influencing the analytical results during sampling, sample preparation, containerization, handling, packaging, preservation and environmental conditions before the samples reach the laboratory. Laboratory QC samples assess only the variability of results introduced by sample handling and preparation in the laboratory and by the analytical procedure, which also impacts field sample duplicates. In addition, the variability in duplicate results is expected to be greater for soil samples than water samples, primarily due to the inherent nonhomogeneous nature of soil samples, despite sample preparation methods that include mixing to improve sample homogeneity.

\section{B.1.1.1.1 Precision for Chemical Analyses}

The RPD criteria used for assessment of laboratory sample duplicate precision for analytical results of samples collected at CAU 140 were established as follows: inorganic analysis RPD criteria is obtained from the EPA Contract Laboratory Program Functional Guidelines for Inorganic Data Review (1994); organic analysis RPD criteria is established by the laboratory to evaluate precision for MSD and LCSD analyses. The control limits are evaluated at the laboratory on a quarterly basis by monitoring the historical data and performance for each method. No review criteria for organic field sample duplicate RPD comparability have been established; therefore, the laboratory MSD RPD criteria is applied for precision evaluation of field sample duplicates.

Precision values for organic and inorganic analysis that are within the established control criteria indicate that precision of analytical methods and laboratory performance is within control. Laboratory duplicate RPD values that are outside the criteria for organic analysis do not necessarily result in the qualification of analytical data. It is only one factor in making an overall judgement about the quality of the reported analytical results. Inorganic laboratory duplicate RPD values outside the established control criteria do result in the qualification of associated analytical results as estimated. Field sample duplicate RPD values that are outside the criteria for organic and inorganic analyses do not result in the qualification of analytical data. Out of control RPD values do not necessarily indicate that the data is not useful for the purpose intended; however, it is an indication 
data precision should be considered for the overall assessment of the data quality and potential impact on data application in meeting project site characterization objectives.

Table B.1-1, Table B.1-2, and Table B.1-3 identify the number of MSD, LCSD, laboratory sample duplicate, and field sample duplicate measurements performed for CAU 140. The tables present the total number of measurements analyzed, the number of measurements within the specified criteria, and the percent precision of each method. Method-specific precision is determined by taking the number of measurements within criteria, dividing that by the total number of measurements analyzed, and multiplying by 100 .

For the purpose of determining data precision of sample analyses for CAU 140, all water and soil samples, including field QC samples (i.e., trip blanks, equipment rinsate samples, field blanks) were evaluated and incorporated into the precision calculation.

Precision for the measurement of target compounds or analytes collected at CAU 140 was determined for RCRA metals, TCLP lead, SVOCs, VOCs, PCBs, TPH DRO and TPH GRO, herbicides, pesticides, explosives, and ethylene glycol.

Inorganic laboratory duplicate RPD values outside the established control criteria result in estimation for that measurement of all associated samples in the SDG. For example, if a laboratory duplicate had an RPD value for lead outside the established control criteria, lead results for all of the samples in that SDG would be qualified as estimated.

Out of control RPD values do not necessarily indicate that the data is not useful for the purpose intended. It does indicate that precision should be considered for the overall assessment of the data quality and impact to the application of associated data to meeting the project's objectives. 
Table B.1-1

Organic Chemical Precision Measurements for CAU 140

\begin{tabular}{|c|c|c|c|c|c|c|c|c|c|}
\hline & \multicolumn{9}{|c|}{ Organics } \\
\hline & VOCs & SVOCs & $\begin{array}{l}\text { TPH } \\
\text { (DRO) }\end{array}$ & $\begin{array}{l}\text { TPH } \\
\text { (GRO) }\end{array}$ & PCBs & Herbicides & Pesticides & Explosives & $\begin{array}{c}\text { Ethylene } \\
\text { Glycol }\end{array}$ \\
\hline \multicolumn{10}{|c|}{ Matrix Spike Duplicate (MSD) Precision } \\
\hline $\begin{array}{l}\text { Total Number of } \\
\text { MSD } \\
\text { Measurements }\end{array}$ & 40 & 88 & 15 & 9 & 16 & 15 & 24 & 28 & 5 \\
\hline $\begin{array}{l}\text { Total Number of } \\
\text { RPDs within } \\
\text { Criteria }\end{array}$ & 40 & 88 & 15 & 8 & 16 & 13 & 24 & 27 & 5 \\
\hline MSD \% Precision & 100 & 100 & 100 & 88.89 & 100 & 86.67 & 100 & 96.43 & 100 \\
\hline \multicolumn{10}{|c|}{ Laboratory Control Sample Duplicate (LCSD) Precision } \\
\hline $\begin{array}{l}\text { Total Number of } \\
\text { LCSD } \\
\text { Measurements }\end{array}$ & 85 & 132 & 15 & 21 & 30 & 30 & 48 & 56 & 7 \\
\hline $\begin{array}{l}\text { Total Number of } \\
\text { RPDs within } \\
\text { Criteria }\end{array}$ & 85 & 132 & 15 & 19 & 30 & 30 & 48 & 55 & 7 \\
\hline LCSD \% Precision & 100 & 100 & 100 & 90.48 & 100 & 100 & 100 & 98.21 & 100 \\
\hline \multicolumn{10}{|c|}{ Field Duplicate (FD) Precision } \\
\hline $\begin{array}{l}\text { Total Number of } \\
\text { FD Measurements }\end{array}$ & 276 & 284 & 5 & 4 & 28 & 10 & 21 & 0 & 1 \\
\hline $\begin{array}{l}\text { Total Number of } \\
\text { RPDs within } \\
\text { Criteria }\end{array}$ & 275 & 284 & 4 & 4 & 28 & 10 & 21 & 0 & 1 \\
\hline FD \% Precision & 99.64 & 100 & 80.0 & 100 & 100 & 100 & 100 & NA & 100 \\
\hline \multicolumn{10}{|c|}{ Laboratory Sample Duplicate (Lab-Dup) Precision } \\
\hline $\begin{array}{l}\text { Total Number of } \\
\text { Lab-Dup } \\
\text { Measurements }\end{array}$ & NA & NA & NA & NA & NA & NA & NA & NA & NA \\
\hline $\begin{array}{l}\text { Total Number of } \\
\text { RPDs within } \\
\text { Criteria }\end{array}$ & NA & NA & NA & NA & NA & NA & NA & NA & NA \\
\hline $\begin{array}{l}\text { Lab-Dup \% } \\
\text { Precision }\end{array}$ & NA & NA & NA & NA & NA & NA & NA & NA & NA \\
\hline
\end{tabular}


Table B.1-2

Inorganic Chemical Precision Measurements for CAU 140

\begin{tabular}{|c|c|c|}
\hline & \multicolumn{2}{|c|}{ Inorganics } \\
\hline & Metals* & Mercury \\
\hline \multicolumn{3}{|c|}{ Matrix Spike Duplicate (MSD) Precision } \\
\hline Total Number of MSD Measurements & 101 & 11 \\
\hline Total Number of RPDs within Criteria & 100 & 11 \\
\hline MSD \% Precision & 99.01 & 100 \\
\hline \multicolumn{3}{|c|}{ Laboratory Control Sample Duplicate (LCSD) Precision } \\
\hline Total Number of LCSD Measurements & 105 & 15 \\
\hline Total Number of RPDs within Criteria & 105 & 15 \\
\hline LCSD \% Precision & 100 & 100 \\
\hline \multicolumn{3}{|c|}{ Field Duplicate (FD) Precision } \\
\hline Total Number of FD Measurements & 33 & 4 \\
\hline Total Number of RPDs within Criteria & 32 & 4 \\
\hline FD \% Precision & 96.97 & 100 \\
\hline \multicolumn{3}{|c|}{ Laboratory Sample Duplicate (Lab-Dup) Precision } \\
\hline Total Number of Lab-Dup Measurements & 101 & 11 \\
\hline Total Number of RPDs within Criteria & 99 & 11 \\
\hline Lab-Dup \% Precision & 98.02 & 100 \\
\hline
\end{tabular}

*Arsenic, Barium, Cadmium, Chromium, Lead, Selenium, Silver, Nickel, Zinc 
Table B.1-3

TCLP Chemical Precision Measurements for CAU 140

\begin{tabular}{|c|c|c|}
\hline & \multicolumn{2}{|c|}{ Inorganics } \\
\hline & TCLP Cadmium & TCLP Lead \\
\hline \multicolumn{3}{|c|}{ TCLP Matrix Spike Duplicate (MSD) Precision } \\
\hline Total Number of MSD Measurements & 1 & 1 \\
\hline Total Number of RPDs within Criteria & 1 & 1 \\
\hline MSD \% Precision & 100 & 100 \\
\hline \multicolumn{3}{|c|}{ TCLP Laboratory Control Sample Duplicate (LCSD) Precision } \\
\hline Total Number of LCSD Measurements & 1 & 1 \\
\hline Total Number of RPDs within Criteria & 1 & 1 \\
\hline LCSD \% Precision & 100 & 100 \\
\hline \multicolumn{3}{|c|}{ TCLP Field Duplicate (FD) Precision } \\
\hline Total Number of FD Measurements & 0 & 0 \\
\hline Total Number of RPDs within Criteria & 0 & 0 \\
\hline FD \% Precision & NA & NA \\
\hline \multicolumn{3}{|c|}{ TCLP Laboratory Sample Duplicate (Lab-Dup) Precision } \\
\hline Total Number of Lab-Dup Measurements & 1 & 1 \\
\hline Total Number of RPDs within Criteria & 1 & 1 \\
\hline Lab-Dup \% Precision & 100 & 100 \\
\hline
\end{tabular}

$\mathrm{NA}=$ Not applicable 


\section{B.1.1.1.2 Precision for Radiological Analysis}

The precision of radiochemical measurements is evaluated by measuring two aliquots of a sample and comparing the results. A laboratory duplicate is measured with every batch of samples analyzed by the laboratory. Field duplicate data is available when two aliquots of a sample are submitted to the laboratory for analysis. Matrix spike duplicates, also used to evaluate precision, are performed by the laboratory upon request.

The duplicate precision is evaluated using the RPD or normalized difference. The RPD is applicable when both the sample and its duplicate have concentrations of the target radionuclide exceeding five times their minimum detectable concentration. This excludes many measurements because the samples contain nondetectable or low levels of the target radionuclide. In situations where the RPD does not apply, duplicate results are evaluated using the normalized difference (ND) which is expressed by:

$$
\mathrm{ND}=(\mathrm{S}-\mathrm{D}) / \sqrt{\left(\mathrm{TPU}_{\mathrm{s}}\right)^{2}+\left(\mathrm{TPU}_{\mathrm{D}}\right)^{2}}
$$

where

$$
\begin{aligned}
& \mathrm{ND}=\text { Normalized Difference } \\
& \mathrm{S}=\text { Sample result } \\
& \mathrm{D}=\text { Duplicate Result } \\
& \mathrm{TPU}_{\mathrm{S}}=2 \sigma \text { TPU of the sample } \\
& \mathrm{TPU}_{\mathrm{D}}=2 \sigma \text { TPU of the duplicate } \\
& \sigma \quad=\text { Standard deviation }
\end{aligned}
$$

The control limit for the ND is -1.96 to 1.96 , which represents a confidence level of 95 percent. Depending on the sample concentration, only one duplicate evaluation needs to be performed.

If the sample duplicate RPD or ND is outside the control limit, the field samples measured in the same analytical batch will be qualified. Samples are not qualified based on field duplicates or MSDs.

A duplicate comparison that is outside control limits does not necessarily indicate that the data is not useful for the purpose intended; however, it is an indication data precision should be considered for the overall assessment of the data quality and potential impact on data application in meeting project site characterization objectives. 
For the purpose of determining data precision of sample analyses for CAU 140, all water and soil duplicates were evaluated and incorporated into Tables B.1-4 through B.1-6.

Table B.1-4

\section{Laboratory Duplicate Precision}

\begin{tabular}{|c|c|c|c|c|c|c|c|}
\hline & $\begin{array}{c}\text { Gamma } \\
\text { Spectrometry }\end{array}$ & $\begin{array}{l}\text { Isotopic } \\
\text { Uranium }\end{array}$ & $\begin{array}{l}\text { Isotopic } \\
\text { Plutonium }\end{array}$ & Strontium-90 & Technetium-99 & $\begin{array}{c}\text { Gross } \\
\text { Beta }\end{array}$ & Tritium \\
\hline \multicolumn{8}{|c|}{ Relative Percent Difference } \\
\hline $\begin{array}{c}\text { No. } \\
\text { Performed }\end{array}$ & 12 & 19 & 3 & 1 & 0 & 0 & 3 \\
\hline $\begin{array}{l}\text { No. within } \\
\text { Limits }\end{array}$ & 12 & 19 & 3 & 1 & 0 & 0 & 3 \\
\hline $\begin{array}{c}\text { Percent } \\
\text { within Limits }\end{array}$ & 100 & 100 & 100 & 100 & NA & NA & 100 \\
\hline \multicolumn{8}{|c|}{ Normalized Differences } \\
\hline $\begin{array}{c}\text { No. } \\
\text { Performed }\end{array}$ & 120 & 5 & 12 & 4 & 1 & 2 & 9 \\
\hline $\begin{array}{l}\text { No. within } \\
\text { Limits }\end{array}$ & 119 & 5 & 12 & 4 & 1 & 2 & 9 \\
\hline $\begin{array}{c}\text { Percent } \\
\text { within Limits }\end{array}$ & 99 & 100 & 100 & 100 & 100 & 100 & 100 \\
\hline
\end{tabular}

Table B.1-5

Laboratory MS/MSD Precision

\begin{tabular}{||c|c|c|c|c||}
\hline & Isotopic Uranium & Isotopic Plutonium & Strontium-90 & Tritium \\
\hline \hline \multicolumn{5}{|c|}{ Relative Percent Difference } \\
\hline \hline No. Performed & 2 & 1 & 1 & 1 \\
\hline No. within Limits & 2 & 1 & 1 & 1 \\
\hline Percent within Limits & 100 & 100 & 100 & 100 \\
\hline
\end{tabular}

The isotopic gamma analysis provides results for 22 radionuclides. Only two or three of these radionuclides are usually present in sufficient concentration to allow the determination of their RPDs. The duplicate data for the remaining radionuclides is compared using the normalized difference. Matrix spike duplicate samples will not be analyzed by the laboratory because of the difficulty in preparing homogeneous spiked duplicates and the radioactive waste produced. 
Table B.1-6

Field Duplicate Precision

\begin{tabular}{|c|c|c|c|c|c|}
\hline & $\begin{array}{c}\text { Gamma } \\
\text { Spectrometry }\end{array}$ & Isotopic Uranium & Isotopic Plutonium & Strontium-90 & Tritium \\
\hline \multicolumn{6}{|c|}{ Relative Percent Difference } \\
\hline No. Performed & 3 & 4 & 1 & 0 & 0 \\
\hline No. within Limits & 3 & 4 & 1 & 0 & 0 \\
\hline Percent within Limits & 100 & 100 & 100 & NA & NA \\
\hline \multicolumn{6}{|c|}{ Normalized Difference } \\
\hline No. Performed & 41 & 2 & 3 & 2 & 1 \\
\hline No. within Limits & 41 & 2 & 3 & 2 & 1 \\
\hline Percent within Limits & 100 & 100 & 100 & 100 & 100 \\
\hline
\end{tabular}

The results of the precision tests for laboratory isotopic gamma measurements are included in Table B.1-4. Five duplicate pairs were measured with each containing 22 radionuclides. All of the RPD comparisons were within limits and 99 percent of the ND tests were acceptable.

The isotopic uranium analysis includes the measurement of three radionuclides, two of which often occur in concentrations sufficient for the RPD evaluation. As shown by the laboratory uranium precision results in Table B.1-4, 100 percent of the RPD tests and ND tests were within limits.

The isotopic plutonium analysis measures two radionuclides but usually their concentrations in samples are too low to permit the evaluation of the RPD. Table B.1-4 contains the precision results for the laboratory duplicates measured with the plutonium laboratory batches and all were acceptable.

The Sr-90, technetium (Tc)-99, gross beta, and tritium analyses provide one result. All of the precision tests, which are included in Table B.1-4, performed for these measurements were within the established control limits. One-hundred percent of the RPD tests and 100 percent of the ND comparisons were within the control limit.

One set of MS and MSD samples was analyzed for isotopic uranium, isotopic plutonium, and strontium-90, and tritium. Since all the samples contained concentrations of the target radionuclide greater than five times the MDC, the RPD comparison was used for each set. As can be seen in Table B.1-5, 100 percent of the MS/MSD precision tests were within the established criteria. 
Overall, 99 percent of the laboratory precision tests for CAU 140 radioanalytical measurements were within the control limits.

The results of the duplicate comparison of the field duplicates are provided in Table B.1-6. Two field duplicates were measured for isotopic U, Sr-90, isotopic Pu, and gamma and one for Tr in CAU 140. All of the precision tests for the field duplicates were within the control limits.

Since 252 of the 253 precision tests performed for laboratory and field duplicates were within limits, 100 percent of all precision tests performed for CAU 140 radiochemical measurements were acceptable.

\section{B.1.1.1.3 Precision Summary}

Overall, the precision for CAU 140 measurements was within DQI specifications. The results of the duplicate comparison of the field and LDs for chemical analyses are provided in Table B.1-1. The results for TCLP analyses are given in Table B.1-3. Of the 666 precision tests performed on FDs, 663 or 99.5 percent were within control limits. Of the 1,136 precision tests for LDs, LCSDs, and MSDs, 1,127 (99.2 percent) were within control limits. The results of the duplicate comparison of the FDs for radiochemical analyses are provided in Table B.1-6. Of the 57 precision tests performed on the FDs, 57 (100 percent) were within the control limits. The results of LDs for radiochemical analyses, including laboratory spike and matrix spike RPDs, are provided in Table B.1-4 and Table B.1-5. Of the 196 precision tests performed for LDs and MSDs, 195 (99.5 percent) were within control limits. Therefore, the measurements for CAU 140 are considered valid in regard to precision.

\section{B.1.1.2 Accuracy}

Accuracy is a measure of the closeness of an individual measurement or the average of a number of measurements to the true value. Accuracy includes a combination of random error (precision) and systematic error (bias) components that result from sampling and analytical operations.

\section{B.1.1.2.1 Accuracy for Chemical Analysis}

Accuracy is determined by analyzing a reference material of known pollutant concentration or by reanalyzing a sample to which a material of known concentration or amount of pollutant has been 
added (spiked). Accuracy is expressed as $\% \mathrm{R}$ for the purposes of evaluating the quality of data reported for CAU 140.

Matrix spikes are generated to provide accuracy of analytical methods, laboratory performance, and matrix influences on the samples. They are prepared by adding a known concentration of a target analyte to a specified amount of matrix sample for which an independent estimate of the target analyte concentration is available. Matrix spike samples are determined by comparing the recovered concentration to the known expected concentration. For example, a sample that is spiked with $10 \mathrm{ppm}$ of a known analyte should produce a reported result of $10 \mathrm{ppm}$ greater than the concentration of the sample itself. Consequently, the accuracy for this analysis would be reported as 100 percent.

Laboratory control samples are generated to provide accuracy of analytical methods and laboratory performance. They are prepared, extracted (as required by method), analyzed, and reported once per SDG per matrix. Laboratory control spiked samples are determined by comparing the recovered concentration to the known expected concentration. For example, a sample that is spiked with $10 \mathrm{ppm}$ of a known analyte should produce a reported result of $10 \mathrm{ppm}$. Consequently, the accuracy for this analysis would be reported as 100 percent.

Surrogates (System Monitoring Compounds) are used to assess the method performance and matrix influences for each sample analyzed for organic analyses. Control limits established by the laboratory are used to evaluate the accuracy of the surrogate recoveries.

For organic analyses, laboratory control limits are used to evaluate the accuracy. The control limits are evaluated at the laboratory quarterly by monitoring the historical data and performance for each method. The acceptable limits for inorganic analyses are established in the EPA's Contract Laboratory Program Functional Guidelines for Inorganic Data Review (1994). Sample results within established control ranges for organic and inorganic analyses indicate the laboratory is operating within established controls. Sample results outside the control may not result in qualification of the data. Factors beyond the laboratory's control, such as sample matrix effects, can cause the measured values to be outside of the established criteria. Therefore, an assessment of the entire analytical process is performed to determine the quality of the data and whether qualification is necessary. For organic analyses, qualification criteria applies only to the native sample in which the spike was added. However, for inorganic analyses, qualification criteria applies to all samples of the 
same matrix of the native sample in which the spike was added within the associated analytical batch. Only the analyte(s) outside of control limits are qualified.

Table B.1-7, Table B.1-8, and Table B.1-9 identify the number of MS, LCS, and surrogate measurements performed for CAU 140. For MS and LCS accuracy, the tables present the total number of measurements analyzed, the number of measurements within the specified criteria, and the percent-accuracy of each method. Method-specific accuracy is determined by taking the number of measurements within criteria, dividing that by the total number of measurements analyzed, and multiplying by 100 . For organic analyses, each sample had surrogates analyzed. Therefore, the tables include the total number of sample measurements performed for each method and the total number of sample measurements not qualified for surrogate recoveries exceeding criteria. Surrogate method-specific accuracy is determined by taking the number of sample measurements not qualified for surrogate recoveries exceeding criteria, dividing that by the total number of sample measurements analyzed, and multiplying by 100 .

Accuracy for the measurement of target analytes collected at CAU 140 was determined for RCRA metals, TCLP lead, SVOCs, VOCs, PCBs, TPH DROs and TPH GRO, herbicides, pesticides, explosives, and ethylene glycol.

For the purpose of determining data accuracy of sample analysis for CAU 140, all water and soil samples including field QC samples (i.e., trip blanks, equipment rinsate samples, field blanks) were evaluated and incorporated into the accuracy calculation.

\section{B.1.1.2.2 Accuracy for Radiological Analysis}

Laboratory control samples and MS samples are used to determine the accuracy of radioanalytical measurements. The LCS is prepared by adding a known concentration of the radionuclide being measured to a sample that does not contain radioactivity (i.e., distilled water). This sample is analyzed with the field samples using the same sample preparation, reagents, and analytical methods employed for the samples. One LCS is prepared with each batch of samples for analysis by a specific measurement. 
Table B.1-7

Organic Laboratory Accuracy Measurements for CAU 140

\begin{tabular}{|c|c|c|c|c|c|c|c|c|c|}
\hline & \multicolumn{9}{|c|}{ Organics } \\
\hline & VOCs & SVOCs & $\begin{array}{l}\text { TPH } \\
\text { (DRO) }\end{array}$ & $\begin{array}{l}\text { TPH } \\
\text { (GRO) }\end{array}$ & PCBs & Herbicides & Pesticides & Explosives & $\begin{array}{c}\text { Ethylene } \\
\text { Glycol }\end{array}$ \\
\hline \multicolumn{10}{|c|}{ Matrix Spike (MS) Accuracy } \\
\hline $\begin{array}{l}\text { Total Number of MS } \\
\text { Measurements }\end{array}$ & 80 & 176 & 30 & 19 & 32 & 30 & 48 & 84 & 10 \\
\hline $\begin{array}{l}\text { Total Number of MS } \\
\text { Measurements within } \\
\text { Criteria }\end{array}$ & 73 & 176 & 30 & 8 & 32 & 29 & 48 & 82 & 10 \\
\hline MS \% Accuracy & 91.25 & 100 & 100 & 42.11 & 100 & 96.67 & 100 & 97.62 & 100 \\
\hline \multicolumn{10}{|c|}{ Laboratory Control Sample (LCS) Accuracy } \\
\hline $\begin{array}{l}\text { Total Number of LCS } \\
\text { Measurements }\end{array}$ & 170 & 264 & 31 & 42 & 60 & 60 & 96 & 112 & 14 \\
\hline $\begin{array}{l}\text { Total Number of LCS } \\
\text { Measurements within } \\
\text { Criteria }\end{array}$ & 170 & 264 & 31 & 42 & 60 & 60 & 96 & 111 & 14 \\
\hline LCS \% Accuracy & 100 & 100 & 100 & 100 & 100 & 100 & 100 & 99.11 & 100 \\
\hline \multicolumn{10}{|c|}{ Surrogate Accuracy } \\
\hline $\begin{array}{l}\text { Total Number of } \\
\text { Measurements } \\
\text { Analyzed }\end{array}$ & 8,487 & 7,588 & 119 & 101 & 791 & 600 & 1,386 & 252 & NA \\
\hline $\begin{array}{l}\text { Total Number of } \\
\text { Measurements not } \\
\text { Affected by } \\
\text { Out-of-Control } \\
\text { Surrogates }\end{array}$ & 8,349 & 7,573 & 117 & 43 & 770 & 600 & 1,384 & 252 & NA \\
\hline $\begin{array}{l}\text { Surrogate \% } \\
\text { Accuracy }\end{array}$ & 98.37 & 99.80 & 98.32 & 42.57 & 97.35 & 100 & 99.86 & 100 & NA \\
\hline
\end{tabular}

NA $=$ Not applicable

Matrix spike samples are prepared by adding a known concentration of a target radionuclide to a specified field sample with a measured concentration. The MS samples are analyzed to determine if the measurement accuracy is affected by the sample matrix. The MS samples are analyzed with sample batches, when requested. For CAU 140, MS samples were performed for the isotopic U, isotopic $\mathrm{Pu}, \mathrm{Sr}-90$, and Tritium analyses. Normally, a MS analysis is not performed for gamma measurements since this is a nondestructive analysis using large sample aliquots. These result in radioactive waste and it is difficult to prepare homogeneous solid spike samples. 
Table B.1-8

Inorganic Laboratory Accuracy Measurements for CAU 140

\begin{tabular}{|c|c|c|}
\hline & \multicolumn{2}{|c|}{ Inorganics } \\
\hline & Metals* & Mercury \\
\hline \multicolumn{3}{|c|}{ Matrix Spike (MS) Accuracy } \\
\hline Total Number of MS Measurements & 202 & 22 \\
\hline Total Number of MS Measurements within Criteria & 195 & 22 \\
\hline MS \% Accuracy & 96.53 & 100 \\
\hline \multicolumn{3}{|c|}{ Laboratory Control Sample (LCS) Accuracy } \\
\hline Total Number of LCS Measurements & 210 & 30 \\
\hline Total Number of LCS Measurements within Criteria & 210 & 30 \\
\hline LCS \% Accuracy & 100 & 100 \\
\hline \multicolumn{3}{|c|}{ Surrogate Accuracy } \\
\hline Total Number of Measurements Analyzed & $\mathrm{N} / \mathrm{A}$ & $\mathrm{N} / \mathrm{A}$ \\
\hline $\begin{array}{l}\text { Total Number of Measurements not affected by } \\
\text { Out-of-Control Surrogates }\end{array}$ & $\mathrm{N} / \mathrm{A}$ & $\mathrm{N} / \mathrm{A}$ \\
\hline Surrogate \% Accuracy & NA & NA \\
\hline
\end{tabular}

*Arsenic, Barium, Beryllium, Cadmium, Chromium, Lead, Selenium, Silver, Nickel, Zinc

NA $=$ Not applicable

Table B.1-9

TCLP Laboratory Accuracy Measurements for CAU 140

\begin{tabular}{|c|c|c|}
\hline & \multicolumn{2}{|c|}{ Organics } \\
\hline & TCLP Cadmium & TCLP Lead \\
\hline \multicolumn{3}{|c|}{ TCLP Matrix Spike (MS) Accuracy } \\
\hline Total Number of MS Measurements & 2 & 2 \\
\hline Total Number of MS Measurements within Criteria & 2 & 2 \\
\hline MS \% Accuracy & 100 & 100 \\
\hline \multicolumn{3}{|c|}{ TCLP Laboratory Control Sample (LCS) Accuracy } \\
\hline Total Number of LCS Measurements & 2 & 2 \\
\hline Total Number of LCS Measurements within Criteria & 2 & 2 \\
\hline LCS \% Accuracy & 100 & 100 \\
\hline \multicolumn{3}{|c|}{ TCLP Surrogate Accuracy } \\
\hline Total Number of Measurements Analyzed & NA & NA \\
\hline $\begin{array}{l}\text { Total Number of Measurements not Affected by } \\
\text { Out-of-Control Surrogates }\end{array}$ & NA & NA \\
\hline Surrogate \% Accuracy & NA & NA \\
\hline
\end{tabular}

$\mathrm{NA}=$ Not applicable 
The accuracy of the LCS determination is expressed as a percent recovery by the following:

$$
\% \text { Recovery }(\% \mathrm{R})=\frac{\text { Amount of analyte measured }}{\text { Amount of analyte added }} \times 100
$$

The accuracy of the MS determination is expressed as a percent recovery by the following:

$$
\% \mathrm{R}=\frac{\text { MS Result }- \text { Sample Result }}{\text { Amount of analyte added }} \times 100
$$

If the LCS recoveries are outside acceptable control limits, qualifiers will be added to the field samples analyzed with the LCS. However, MS results outside this control range may not result in qualification of the data. An assessment of the entire analytical process including the sample matrix is performed to determine if qualification is necessary.

Table B.1-10 and Table B.1-11 identify the number of LCS and MS samples, including soil and water matrices, measured for each radiochemical measurement included in CAU 140. The percent accuracy for the procedure is determined as the number of MS or LCS samples analyzed within the control limits divided by the total number analyzed, and multiplied by 100 .

Each isotopic gamma LCS sample contains four or five radionuclides, each of which has a percent recovery determined. Matrix spike measurements are usually not performed with gamma measurements because of the difficulty in preparing homogeneous samples and the radioactive waste created.

Three uranium radionuclides are added to the isotopic uranium LCS and MS samples, but the U-235 concentration is usually too low to allow evaluation. The isotopic Pu, Sr-90, and Tritium LCS and MS samples contain one added radionuclide.

Laboratory control samples within the specified criteria for radiological analyses indicate the laboratory is producing valid data. If the LCS criteria are not met, the laboratory performance and method accuracy are in question. Radiological LCS recoveries outside of established controls require 
Table B.1-10

Radioanalytical Laboratory Control Sample (LCS) Accuracy

\begin{tabular}{|l|c|c|c|c|c|c|c||}
\hline & $\begin{array}{c}\text { Gamma } \\
\text { Spectrometry }\end{array}$ & $\begin{array}{c}\text { Isotopic } \\
\text { Uranium }\end{array}$ & $\begin{array}{c}\text { Isotopic } \\
\text { Plutonium }\end{array}$ & Strontium-90 & Technetium-99 & $\begin{array}{c}\text { Gross } \\
\text { Beta }\end{array}$ & Tritium \\
\hline \hline Total Number & 24 & 14 & 6 & 5 & 1 & 2 & 8 \\
\hline $\begin{array}{l}\text { Total Number } \\
\text { within Criteria }\end{array}$ & 24 & 14 & 6 & 5 & 1 & 2 & 8 \\
\hline $\begin{array}{l}\text { LCS \% } \\
\text { Accuracy }\end{array}$ & 100 & 100 & 100 & 100 & 100 & 100 & 100 \\
\hline
\end{tabular}

Table B.1-11

Radioanalytical Matrix Spike (MS) Accuracy

\begin{tabular}{|l|c|c|c|c|}
\hline & Tritium & Isotopic Uranium & Isotopic Plutonium & Strontium-90 \\
\hline \hline Total Number & 4 & 4 & 2 & 2 \\
\hline $\begin{array}{l}\text { Total Number within } \\
\text { Criteria }\end{array}$ & 4 & 4 & 2 & 2 \\
\hline MS \% Accuracy & 100 & 100 & 100 & 100 \\
\hline
\end{tabular}

data to be qualified for the individual radionuclide out of control. Since LCS recoveries were 100 percent for all analyses, no field samples were qualified based on LCS performance.

None of the MS recoveries were outside control limits. Thus, all the CAU 140 accuracy tests were acceptable.

\section{B.1.1.2.3 Accuracy Summary}

Overall, the accuracy for CAU 140 was within acceptable limits. Surrogate recoveries, which gauge the accuracy of individual sample results for specified chemical analyses, were within acceptable accuracy ranges (97.4 percent or better) with the exception of TPH (GRO) which was 42.1 percent. This low recovery was due to matrix affects. All the results were evaluated during the data validation process and qualified as estimated. All TPH (GRO) results of the affected samples were less than the contract-required detection limit (CRDL); therefore, these results do not affect decisions for corrective actions. Acceptable MS recovery results were 91.3 percent or better for chemical and radiochemical analyses with the exception of TPH (GRO), which was at 42.1 percent. Although 8 of 
19 MS measurements were out of criteria, only 4 of 102 sample results were affected and qualified, which results in a 96 percent accuracy. The LCS percent accuracy for the chemical and radioanalytical measurements was 100 percent. Therefore, the measurements for CAU 140 are considered valid in regard to accuracy.

\section{B.1.1.3 Completeness}

Completeness is defined as the acquisition of sufficient data of the appropriate quality to satisfy DQO decision data requirements. A measure of completeness is the amount of data that are judged to be valid. Percent completeness for sample analyses was determined by dividing the total number of samples analyzed (per method) by the total number of samples sent to the lab and multiplied by 100 . Percent completeness for measurement usability (not rejected) was determined by dividing the total number of nonrejected measurements by the total number measurements (per method) and multiplying by 100. All measurement for completeness include reanalyses. Tables B.1-12 through B.1-15 contain results of completeness per analytical method.

The specified sampling locations were used as planned and all samples were collected as specified in the CAU 140 CAIP (NNSA/NV, 2002). No analyses were compromised as a result of sample containers not reaching the laboratory intact.

In accordance with the CAU 140 CAIP (Table A.1-4), 100 percent completeness of critical analytes has been achieved with the exception of CAS 05-35-01, which had one sample rejected for naphthalene (pryolytic oil); CASs 05-08-02, 05-17-01, and 23-17-01, which had four samples rejected for a variety of SVOC compounds; and CAS 23-17-01, which had six samples rejected for acetone (VOC). Eighty percent completeness of noncritical analytes has been met.

Rejected data affecting completeness are presented and discussed in the following sections. 
Table B.1-12

Organic Chemical Completeness for CAU 140

\begin{tabular}{|c|c|c|c|c|c|c|c|c|c|}
\hline \multirow{2}{*}{$\begin{array}{l}\text { Completeness } \\
\text { Parameters }\end{array}$} & \multicolumn{9}{|c|}{ Organics } \\
\hline & VOCs & svocs & $\begin{array}{l}\text { TPH } \\
\text { (DRO) }\end{array}$ & $\begin{array}{l}\text { TPH } \\
\text { (GRO) }\end{array}$ & PCBs & Herbicides & Pesticides & Explosives & $\begin{array}{c}\text { Ethylene } \\
\text { Glycol }\end{array}$ \\
\hline \multicolumn{10}{|c|}{ Sample Analysis Completeness } \\
\hline $\begin{array}{l}\text { Total Samples } \\
\text { Sent to Laboratory }\end{array}$ & 123 & 107 & 119 & 102 & 113 & 60 & 66 & 18 & 60 \\
\hline $\begin{array}{l}\text { Total Samples } \\
\text { Analyzed }\end{array}$ & 123 & 107 & 119 & 102 & 113 & 60 & 66 & 18 & 60 \\
\hline $\begin{array}{l}\text { Total Samples Not } \\
\text { Analyzed by } \\
\text { Laboratory }\end{array}$ & 0 & 0 & 0 & 0 & 0 & 0 & 0 & 0 & 0 \\
\hline $\begin{array}{l}\text { Percent } \\
\text { Completeness }\end{array}$ & 100 & 100 & 100 & 100 & 100 & 100 & 100 & 100 & 100 \\
\hline \multicolumn{10}{|c|}{ Measurement Usability Completeness } \\
\hline $\begin{array}{l}\text { Total } \\
\text { Measurements* }\end{array}$ & 8,487 & 7,588 & 119 & 101 & 791 & 600 & 1,366 & 252 & 60 \\
\hline $\begin{array}{l}\text { Total } \\
\text { Measurements } \\
\text { Rejected - Field }\end{array}$ & 0 & 0 & 0 & 0 & 0 & 0 & 0 & 0 & 0 \\
\hline $\begin{array}{l}\text { Total } \\
\text { Measurements } \\
\text { Rejected - } \\
\text { Laboratory/Matrix }\end{array}$ & 27 & 53 & 0 & 0 & 0 & 0 & 0 & 2 & 0 \\
\hline $\begin{array}{l}\text { Percent } \\
\text { Completeness }\end{array}$ & 99.68 & 99.30 & 100 & 100 & 100 & 100 & 100 & 99.21 & 100 \\
\hline
\end{tabular}

*Measurements include reanalyses 
Table B.1-13

Inorganic Chemical Completeness for CAU 140

\begin{tabular}{|c|c|c|}
\hline \multirow{2}{*}{ Completeness Parameters } & \multicolumn{2}{|c|}{ Inorganics } \\
\hline & Metals* & Mercury \\
\hline \multicolumn{3}{|c|}{ Sample Analysis Completeness } \\
\hline Total Samples sent to Laboratory & 118 & 114 \\
\hline Total Samples Analyzed & 118 & 114 \\
\hline Total Samples not Analyzed by the Laboratory & 0 & 0 \\
\hline Percent Completeness & 100 & 100 \\
\hline \multicolumn{3}{|c|}{ Measurement Usability Completeness } \\
\hline Total Measurements ** & 872 & 114 \\
\hline Total Measurements Rejected - Field & 0 & 0 \\
\hline Total Measurements Rejected - Laboratory/Matrix & 13 & 0 \\
\hline Percent Completeness & 98.51 & 100 \\
\hline
\end{tabular}

*Arsenic, Barium, Beryllium, Cadmium, Chromium, Lead, Selenium, Silver, Nickel, Zinc

${ }^{* *}$ Measurements include reanalysis

Table B.1-14

TCLP Completeness for CAU 140

\begin{tabular}{|c|c|c|}
\hline \multirow{2}{*}{ Completeness Parameters } & \multicolumn{2}{|c|}{ Inorganics } \\
\hline & TCLP Cadmium & TCLP Lead \\
\hline \multicolumn{3}{|c|}{ Sample Analysis Completeness } \\
\hline Total Samples Sent to Laboratory & 1 & 1 \\
\hline Total Samples Analyzed & 1 & 1 \\
\hline Total Samples Not Analyzed by the Laboratory & 0 & 0 \\
\hline Percent Completeness & 100 & 100 \\
\hline \multicolumn{3}{|c|}{ Measurement Usability Completeness } \\
\hline Total Measurements* & 1 & 1 \\
\hline Total Measurements Rejected - Field & 0 & 0 \\
\hline Total Measurements Rejected - Laboratory/Matrix & 0 & 0 \\
\hline Percent Completeness & 100 & 100 \\
\hline
\end{tabular}

*Measurements include reanalyses 
Table B.1-15

Radiological Completeness for CAU 140

\begin{tabular}{|c|c|c|c|c|c|c|c|}
\hline $\begin{array}{l}\text { Completeness } \\
\text { Parameters }\end{array}$ & Tritium & $\begin{array}{c}\text { Gamma } \\
\text { Spectrometry }\end{array}$ & $\begin{array}{c}\text { Gross } \\
\text { Alpha/Beta }\end{array}$ & $\begin{array}{l}\text { Isotopic } \\
\text { Uranium }\end{array}$ & Strontium-90 & Technetium-99 & $\begin{array}{l}\text { Isotopic } \\
\text { Plutonium }\end{array}$ \\
\hline \multicolumn{8}{|c|}{ Sample Analysis Completeness } \\
\hline $\begin{array}{l}\text { Total Samples } \\
\text { Sent to Laboratory }\end{array}$ & 60 & 31 & 2 & 30 & 25 & 1 & 26 \\
\hline $\begin{array}{l}\text { Total Samples } \\
\text { Analyzed }\end{array}$ & 60 & 31 & 2 & 30 & 25 & 1 & 26 \\
\hline $\begin{array}{l}\text { Total Samples Not } \\
\text { Analyzed by the } \\
\text { Laboratory }\end{array}$ & 0 & 0 & 0 & 0 & 0 & 0 & 0 \\
\hline $\begin{array}{l}\text { Percent } \\
\text { Completeness }\end{array}$ & 100 & 100 & 100 & 100 & 100 & 100 & 100 \\
\hline \multicolumn{8}{|c|}{ Measurement Usability Completeness } \\
\hline $\begin{array}{l}\text { Total } \\
\text { Measurements* }\end{array}$ & 60 & 682 & 2 & 90 & 25 & 1 & 52 \\
\hline $\begin{array}{l}\text { Total } \\
\text { Measurements } \\
\text { Rejected - Field }\end{array}$ & 0 & 0 & 0 & 0 & 0 & 0 & 0 \\
\hline $\begin{array}{l}\text { Total } \\
\text { Measurements } \\
\text { Rejected - } \\
\text { Laboratory/Matrix }\end{array}$ & 0 & 2 & 0 & 0 & 0 & 0 & 0 \\
\hline $\begin{array}{l}\text { Percent } \\
\text { Completeness }\end{array}$ & 100 & 99.71 & 100 & 100 & 100 & 100 & 100 \\
\hline
\end{tabular}

*Measurements include reanalyses 


\section{B.1.1.4 Rejected Data}

\section{Detonation Pits (CAS 05-08-01) Rejected Data}

Table B.1-16 lists the rejected results per analytical method for CAS 05-08-01. All other results are considered usable. The americium (Am)-241 result was rejected because of interference from the presence of Th-234 in the sample. No Am-241 was detected in any of the soil samples. This rejected soil result is considered an acceptable data gap because it does not affect closure decisions.

Table B.1-16

CAU 140 Rejected Data for CAS 05-08-01

\begin{tabular}{||c|c|c|c|c|}
\hline $\begin{array}{c}\text { Sample } \\
\text { Number }\end{array}$ & Parameter & $\begin{array}{c}\text { CAS } \\
\text { Number }\end{array}$ & Analyte & $\begin{array}{c}\text { Sample } \\
\text { Matrix }\end{array}$ \\
\hline \hline $140 \mathrm{~A} 005$ & Gamma Spectrometry & $14596-10-2$ & Americium-241 & Soil \\
\hline
\end{tabular}

\section{Debris Pits (CAS 05-08-02) Rejected Data}

Table B.1-17 lists the rejected results per analytical method for CAS 05-08-02. All other results are considered usable. The rejected SVOC results in two soil samples were due to the internal area response showing an extremely low count. No SVOCs were detected above minimum reporting limits in any of the usable SVOC results; therefore, these analytes are not likely to be present. Therefore, these rejected data are considered acceptable data gaps because they do not affect closure decisions.

\section{Hazardous Waste Accumulation Site (Buried) (CAS 05-17-01) Rejected Data}

Table B.1-18 lists the rejected results per analytical method for CAS 05-17-01. All other results are considered usable. The rejected SVOC results in one soil sample was due to the internal area response showing an extremely low count. No SVOCs were detected above minimum reporting limits in any of the usable SVOC results; therefore, these analytes are not likely to be present. Therefore, these rejected data are considered acceptable data gaps because they do not affect closure decisions.

\section{Waste Disposal Site (CAS 05-19-01) Rejected Data}

All analytical results for CAS 05-19-01 are considered usable. 
Table B.1-17

CAU 140 Rejected Data for CAS 05-08-02

\begin{tabular}{|c|c|c|c|c|}
\hline $\begin{array}{l}\text { Sample } \\
\text { Number }\end{array}$ & Parameter & $\begin{array}{c}\text { CAS } \\
\text { Number }\end{array}$ & Analyte & $\begin{array}{c}\text { Sample } \\
\text { Matrix }\end{array}$ \\
\hline 140B008 & $\overline{\text { SVOCs }}$ & $\overline{991-94-1}$ & 3,3'-Dichlorobenzidine & Soil \\
\hline 140B008 & SVOCs & $56-55-3$ & Benzo(A)Anthracene & Soil \\
\hline 140B008 & SVOCs & $50-32-8$ & Benzo(A)Pyrene & Soil \\
\hline 140B008 & SVOCs & $205-99-2$ & Benzo(B)Fluoranthene & Soil \\
\hline 140B008 & SVOCs & $191-24-2$ & Benzo(G,H,I)Perylene & Soil \\
\hline 140B008 & SVOCs & $207-08-9$ & Benzo(K)Fluoranthene & Soil \\
\hline 140B008 & SVOCs & $117-81-7$ & Bis(2-Ethylhexyl)Phthalate & Soil \\
\hline 140B008 & SVOCs & $85-68-7$ & Butyl Benzyl Phthalate & Soil \\
\hline 140B008 & SVOCs & $218-01-9$ & Chrysene & Soil \\
\hline 140B008 & SVOCs & $53-70-3$ & Dibenzo(A,H)Anthracene & Soil \\
\hline 140B008 & SVOCs & $117-84-0$ & Di-N-Octyl Phthalate & Soil \\
\hline 140B008 & SVOCs & $193-39-5$ & Indeno(1,2,3-CD)Pyrene & Soil \\
\hline 140B010 & SVOCs & $91-94-1$ & 3,3'-Dichlorobenzidine & Soil \\
\hline 140B010 & SVOCs & $56-55-3$ & Benzo(A)Anthracene & Soil \\
\hline 140B010 & SVOCs & $117-81-7$ & Bis(2-Ethylhexyl)Phthalate & Soil \\
\hline 140B010 & SVOCs & $85-68-7$ & Butyl Benzyl Phthalate & Soil \\
\hline 140B010 & SVOCs & $218-01-9$ & Chrysene & Soil \\
\hline 140B010 & SVOCs & $117-84-0$ & Di-N-Octyl Phthalate & Soil \\
\hline 140B010 & SVOCs & $129-00-0$ & Pyrene & Soil \\
\hline
\end{tabular}

\section{Gravel Gertie (CAS 05-23-01) Rejected Data}

All analytical results for CAS 05-23-01 are considered usable.

\section{Burn Pit (CAS 05-35-01) Rejected Data}

Table B.1-19 lists the rejected results per analytical method for CAS 05-35-01. All other results are considered usable. The rejected SVOC results in one soil sample was due to the internal area response showing an extremely low count. No SVOCs were detected above minimum reporting limits in any of the usable SVOC results; therefore, these analytes are not likely to be present. Therefore, these rejected data are considered acceptable data gaps because they do not affect closure decisions. 
Table B.1-18

CAU 140 Rejected Data for CAS 05-17-01

\begin{tabular}{||c|c|c|c|c||}
\hline $\begin{array}{c}\text { Sample } \\
\text { Number }\end{array}$ & Parameter & $\begin{array}{c}\text { CAS } \\
\text { Number }\end{array}$ & Analyte & $\begin{array}{c}\text { Sample } \\
\text { Matrix }\end{array}$ \\
\hline \hline $140 \mathrm{C} 004$ & SVOCs & $91-94-1$ & $3,3^{\prime}-$ Dichlorobenzidine & Soil \\
\hline $140 \mathrm{C} 004$ & SVOCs & $56-55-3$ & Benzo(A)Anthracene & Soil \\
\hline $140 \mathrm{C} 004$ & SVOCs & $50-32-8$ & Benzo(A)Pyrene & Soil \\
\hline $140 \mathrm{C} 004$ & SVOCs & $205-99-2$ & Benzo(B)Fluoranthene & Soil \\
\hline $140 \mathrm{C} 004$ & SVOCs & $191-24-2$ & Benzo(G,H,I)Perylene & Soil \\
\hline $140 \mathrm{C} 004$ & SVOCs & $207-08-9$ & Benzo(K)Fluoranthene & Soil \\
\hline $140 \mathrm{C} 004$ & SVOCs & $117-81-7$ & Bis(2-Ethylhexyl)Phthalate & Soil \\
\hline $140 \mathrm{C} 004$ & SVOCs & $85-68-7$ & Butyl Benzyl Phthalate & Soil \\
\hline $140 \mathrm{C} 004$ & SVOCs & $218-01-9$ & Chrysene & Soil \\
\hline $140 \mathrm{C} 004$ & SVOCs & $53-70-3$ & Dibenzo(A,H)Anthracene & Soil \\
\hline $140 \mathrm{C} 004$ & SVOCs & $117-84-0$ & Di-N-Octyl Phthalate & Soil \\
\hline $140 \mathrm{C} 004$ & SVOCs & $193-39-5$ & Indeno(1,2,3-CD)Pyrene & Soil \\
\hline $140 \mathrm{C} 004$ & SVOCs & $129-00-0$ & Pyrene & Soil \\
\hline
\end{tabular}

\section{Burn Pit (CAS 05-99-04) Rejected Data}

All analytical results for CAS 05-99-01 are considered usable.

\section{Radioactive Waste Dump (CAS 22-99-04) Rejected Data}

All analytical results for CAS 22-99-04 are considered usable.

\section{Hazardous Waste Storage Area (CAS 23-17-01) Rejected Data}

Table B.1-20 lists the rejected results per analytical method for CAS 23-17-01. All other results are considered usable. The rejected SVOC results in one soil sample was due to the internal area response showing an extremely low count. One sample had an SVOC detected above minimum reporting limits. This analyte is not considered a COPC at this CAS. Several samples were rejected for silver due to the matrix spike recovery being grossly outside of the control limits. This analyte is not considered a COPC at this CAS. Therefore, these rejected data are considered acceptable data gaps because they do not affect closure decisions. 
Table B.1-19

CAU 140 Rejected Data for CAS 05-35-01

\begin{tabular}{|c|c|c|c|c|}
\hline $\begin{array}{l}\text { Sample } \\
\text { Number }\end{array}$ & Parameter & $\begin{array}{c}\text { CAS } \\
\text { Number }\end{array}$ & Analyte & $\begin{array}{c}\text { Sample } \\
\text { Matrix }\end{array}$ \\
\hline 140F002 & VOCs & $79-34-5$ & $\overline{1,1,2,2-\text { Tetrachloroethane }}$ & $\overline{\text { Soil }}$ \\
\hline 140F002 & VOCs & $87-61-6$ & 1,2,3-Trichlorobenzene & Soil \\
\hline 140F002 & VOCs & $96-18-4$ & 1,2,3-Trichloropropane & Soil \\
\hline 140F002 & VOCs & $120-82-1$ & 1,2,4-Trichlorobenzene & Soil \\
\hline 140F002 & VOCs & $95-63-6$ & 1,2,4-Trimethylbenzene & Soil \\
\hline 140F002 & VOCs & $96-12-8$ & 1,2-Dibromo-3-Chloropropane & Soil \\
\hline 140F002 & VOCs & $95-50-1$ & 1,2-Dichlorobenzene & Soil \\
\hline 140F002 & VOCs & $108-67-8$ & 1,3,5-Trimethylbenzene & Soil \\
\hline 140F002 & VOCs & $541-73-1$ & 1,3-Dichlorobenzene & Soil \\
\hline 140F002 & VOCs & $106-46-7$ & 1,4-Dichlorobenzene & Soil \\
\hline 140F002 & VOCs & $95-49-8$ & 2-Chlorotoluene & Soil \\
\hline 140F002 & VOCs & $108-86-1$ & Bromobenzene & Soil \\
\hline 140F002 & VOCs & $87-68-3$ & Hexachlorobutadiene & Soil \\
\hline 140F002 & VOCs & $98-82-8$ & Isopropylbenzene & Soil \\
\hline 140F002 & VOCs & $91-20-3$ & Naphthalene & Soil \\
\hline 140F002 & VOCs & $104-51-8$ & N-Butylbenzene & Soil \\
\hline 140F002 & VOCs & $103-65-1$ & N-Propylbenzene & Soil \\
\hline 140F002 & VOCs & $99-87-6$ & P-Isopropyltoluene & Soil \\
\hline 140F002 & VOCs & $135-98-8$ & Sec-Butylbenzene & Soil \\
\hline 140F002 & VOCs & $98-06-6$ & Tert-Butylbenzene & Soil \\
\hline
\end{tabular}

\section{B.1.1.5 Representativeness}

The DQO process, as identified in Appendix A of the CAIP, was used to address sampling and analytical requirements for CAU 140. During this process, appropriate biased locations were selected that enabled the collected samples to be representative of the area being evaluated. Biased sampling was performed to ensure sampling of suspected or known contamination. In addition, analytical requirements were specified in order to ensure appropriate methods were selected for COPCs. This was performed to address the concerns of all stakeholders and project personnel. The DQO approach was based upon process knowledge gained during the preliminary assessment. Samples were collected and analyzed as planned with the completeness issues discussed above. In addition, QC blanks were used as a way of measuring outside factors that could impact sample results. No 
Table B.1-20

CAU 140 Rejected Data for CAS 23-17-01

\begin{tabular}{||c|c|c|c|c||}
\hline $\begin{array}{c}\text { Sample } \\
\text { Number }\end{array}$ & Parameter & $\begin{array}{c}\text { CAS } \\
\text { Number }\end{array}$ & Analyte & $\begin{array}{c}\text { Sample } \\
\text { Matrix }\end{array}$ \\
\hline \hline 140J015 & SVOCs & $50-32-8$ & Benzo(A)Pyrene & Soil \\
\hline 140J015 & SVOCs & $205-99-2$ & Benzo(B)Fluoranthene & Soil \\
\hline 140J015 & SVOCs & $191-24-2$ & Benzo(G,H,I)Perylene & Soil \\
\hline 140J015 & SVOCs & $207-08-9$ & Benzo(K)Fluoranthene & Soil \\
\hline 140J015 & SVOCs & $53-70-3$ & Dibenzo(A,H)Anthracene & Soil \\
\hline 140J015 & SVOCs & $193-39-5$ & Indeno(1,2,3-CD)Pyrene & Soil \\
\hline 140J033 & RCRA Metals & $7440-22-4$ & Silver & Soil \\
\hline 140J034 & RCRA Metals & $7440-22-4$ & Silver & Soil \\
\hline 140J035 & RCRA Metals & $7440-22-4$ & Silver & Soil \\
\hline 140J036 & RCRA Metals & $7440-22-4$ & Silver & Soil \\
\hline 140J037 & RCRA Metals & $7440-22-4$ & Silver & Soil \\
\hline 140J038 & RCRA Metals & $7440-22-4$ & Silver & Soil \\
\hline 140J039 & RCRA Metals & $7440-22-4$ & Silver & Soil \\
\hline 140J040 & RCRA Metals & $7440-22-4$ & Silver & Soil \\
\hline 140J043 & RCRA Metals & $7440-22-4$ & Silver & Soil \\
\hline 140J044 & RCRA Metals & $7440-22-4$ & Silver & Soil \\
\hline 140J045 & RCRA Metals & $7440-22-4$ & Silver & Soil \\
\hline 140J046 & RCRA Metals & $7440-22-4$ & Silver & \\
\hline 140J314 & RCRA Metals & $7440-22-4$ & & \\
\hline
\end{tabular}

significant impacts to data were identified due to QC blanks. Therefore, the analytical data acquired during the CAU 140 corrective action investigation are considered representative of site characteristics and contamination.

\section{B.1.1.6 Comparability}

Field sampling, as described in the CAU 140 CAIP, was performed and documented in accordance with approved procedures that are comparable to standard industry practices. Approved analytical methods and procedures per DOE were used to analyze, report, and validate the data. These are comparable to other methods used in industry and government practices, but most importantly are comparable to other investigations conducted for the NTS. Therefore, datasets within this project are considered comparable to other datasets generated using these same standardized DOE procedures, 
thereby meeting DQO requirements. The employed methods and procedures also ensured that data were appropriate for comparison to action levels specified in the CAIP and this CADD.

\section{B.1.2 Reconciliation of Conceptual Site Models to the Data}

This section provides a reconciliation of the data collected and analyzed during this investigation with the conceptual site models established in the DQO process.

\section{B.1.2.1 Conceptual Site Models}

Three CSMs were developed for the CAU 140 CASs as presented in the CAIP (NNSA/NV, 2002). The CSMs were based on historical information and process knowledge. Each CSM is discussed in the following sections.

\section{B.1.2.1.1 Surface Materials Conceptual Site Model}

This section describes CSM elements for CAU 140. All nine CASs are included in this category:

- 05-08-01, Detonation Pits

- 05-08-02, Debris Pits

- 05-17-01, Hazardous Waste Accumulation Site (Buried)

- 05-19-01, Waste Disposal Site

- 05-23-01, Gravel Gertie

- 05-35-01, Burn Pit

- 05-99-04, Burn Pit

- 22-99-04, Radioactive Waste Dump

- 23-17-01, Hazardous Waste Storage Area

The primary source of potential contamination is associated with burning activities, aerial dispersion testing, munitions detonation, and erosion of various contaminants off the surface of solid materials and the associated potential releases of COPCs into surface and near-surface soil. Therefore, the general CSM included soil potentially impacted by surface and subsurface disposal/release of effluent. The mechanisms for this type of release include both designed (i.e., burning, detonations) and accidental (e.g., drum breakage) releases. Surface migration may have occurred at any of the CASs due to surface flow during rain events, grading activities, or wind. The CSM was determined to be valid for all CASs. 


\section{B.1.2.1.2 Buried Debris Conceptual Site Model}

This section describes CSM elements for two CASs. The following CASs are included in this category:

- 05-19-01, Waste Disposal Site

- 23-17-01, Hazardous Waste Storage Area

The primary source of potential contamination for these CASs is associated with the assumed release of COPCs into the near-surface and subsurface soil immediately surrounding the buried liquid or solid waste. The primary mechanisms for this type of release include direct release to the subsurface of liquid waste or leaching of contaminants off the surface of the buried materials. This CSM was thought to apply to CASs 05-08-01, 05-17-01, and 05-19-01; however, no buried debris were found at these CASs. This CSM was determined to be valid for CAS 23-17-01 only.

\section{B.1.2.1.3 Internal Structure Conceptual Site Model}

This section describes CSM elements for CAS 05-23-01. The primary source of potential contamination for this CAS is associated HE detonations and the assumed release of COPCs into concrete walls, floor, and the gravel/soil making up the roof of the Gravel Gertie. Infiltration from precipitation is not considered to be a current transport mechanism for moving contaminants due to restricted rainfall, high evaporation, and the structure of the Gravel Gertie protects against runon. The CSM was determined to be valid for CAS 05-23-01.

\section{B.1.2.2 Investigation Design and Contaminant Identification}

The CSMs were used as the basis for identifying appropriate sampling strategies and data collection methods. Results of DQIs were successful in identifying the accuracy of the CSM as a predication of the nature and extent of potential contamination. Precision and accuracy results from the field samples identified sample homogeneity and minimal matrix interference, thereby providing confidence in collected data.

To address the CAS-specific CSMs, surface and subsurface samples collected for analyses were designed to define the nature and extent of the COPCs identified in the CAIP. Biased strategies were developed to focus the investigation on areas of potential contamination. 
The investigation design has shown that contamination did not extend beyond the immediate vicinity of the CAS system component. Therefore, the CSMs accurately predict the extent of COPCs at each CAS. The models were designed to determine the extent of impact on contaminated effluent released to the soil. The CSMs were successful in predicting contaminant location, and the DQIs provided a measure of the success of this design.

\section{B.1.2.3 Contaminant Nature and Extent}

The presence of contamination was identified by sample results showing COPC soil concentrations exceeding PALs established in the CAIP, thereby defining COCs at each CAS. In general, soil sample results demonstrated that the vertical and lateral extent of COCs was limited to the physical boundaries of the CSMs defined in the CAIP. Field screening was conducted and samples were collected at locations to bound contaminated areas with results below action levels. This confirmed that the extent of contamination was limited to anticipated regions defined by the CAS-specific CSMs. The CAS-specific investigation findings, analytical results, and descriptions of site conditions are presented in Appendix A of this CADD.

\section{B.1.3 Conclusions}

Samples were collected and analyzed as planned and within acceptable performance limits except where noted.

The DQIs (i.e., precision, accuracy, completeness, representativeness, and comparability) were evaluated for quality impact to the data. All of the data, except data qualified as rejected, can be used in project decisions. The rejected data have been discussed and determined to have little impact on closure decisions.

Thus, the DQIs for the investigation have been met, and the data can be used to develop corrective action alternatives and to support selection of a preferred closure alternative for each CAS. 


\section{B.2.0 References}

EPA, see U.S. Environmental Protection Agency.

NNSA/NV, see U.S. Department of Energy, National Nuclear Security Administration Nevada Operations Office.

U.S. Department of Energy, National Nuclear Security Administration Nevada Operations Office. 2002. Corrective Action Investigation Plan for Corrective Action Unit 140: Waste Dumps, Burn Pits, and Storage Area, Nevada Test Site, Nevada, DOE/NV--826. Las Vegas, NV.

U.S. Environmental Protection Agency. 1994. Contract Laboratory Program National Functional Guidelines for Inorganic Data Review, EPA 540-R-94/013. Washington, DC.

U.S. Environmental Protection Agency. 1996. Test Methods for Evaluating Solid Waste, Physical/Chemical Methods, SW-846 CD ROM PB97-501928GEI, which contains updates for 1986, 1992, 1994, and 1996. Washington, DC. 


\section{Appendix C}

\section{Cost Estimates for CAU 140}

(8 Pages) 


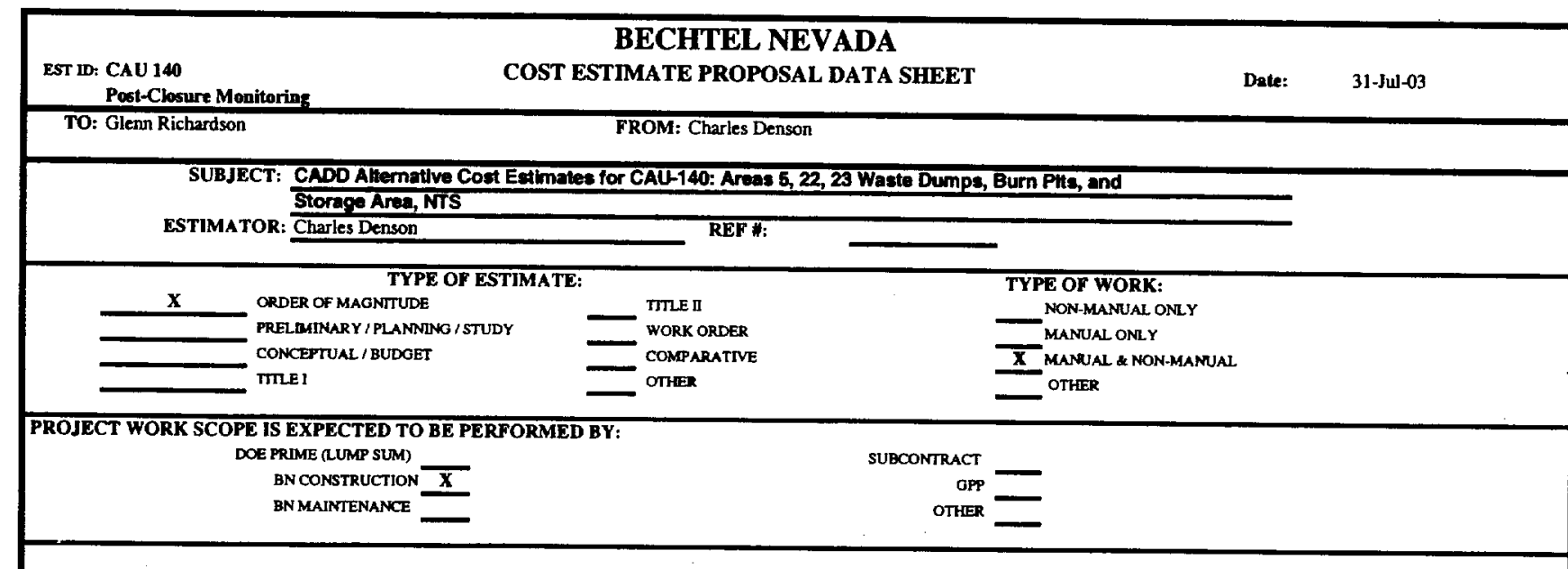

\section{STATEMENT OF WORK}

This estimate has been prepared to provide post-remedial altemative costs for the post closure care of Corrective Action Sites included within Corrective Action Unit (CAU) 140. This estimate for post-closure monitoring applies to all of the CASs in CAU 140, an environmental restoration site listed in the Federal Facility Agreement and Consent Order (FFACO), that will not be clean-closed. Two altematives have been provided for post-closure monitoring of the sites: (1) Post-Closure Monitoring (PCM) for Closure in Place with No Cover and (2) PCM for Closure in Place with a Cover. This estimate will be used to identify the most cost effective alternative for closure of the site while remaining protective of human health and the environment.

SCOPE:

Provide post-closure monitoring at $\mathrm{CAU} 140$ sites that have been closed in place under one of the following alternatives: I PCM FOR CLOSURE IN PLACE WITH ADMINISTRATIVE CONTROLS, II PCM FOR CLOSURE IN PLACE WITH CONSTRUCTION OF COVERS

\section{BASIS:} Two closure scenarios are provided for each of nine CASs will likely require post-ctosure monitoring. This estimate assumes that one of the two closure
scenarios will be selected for all of the CASs, and that all of the post-closure monitoring will be planned and performed together. Estimates for each alternative were priced using standard construction references such as AS Means, Richardson's, and the BN estimating database.

\section{ALTERNATIVE SPECIFIC BASIS OF ESTIMATE/ASSUMPTIONS}

Alternatlve I: Post-Closure Monitoring for Closure in Place with Administrative Controls, No Cover

- Assumes that all CASs will require drive-by inspections annually during post-closure years 1 through 5 and every 5 years thereafter until year 20 (i.e. inspections during post-closure years $1,2,3,4,5,10,15$, and 20).

- Assumes that onty signs, posts, and fencing will need to be maintained post-closure.

- Assumes that maintenance will be required at all sites during years 2 and 5 , but that no maintenance will be required in other years.

- Assumes that the post-closure report will consist of a letter report that is required only duting those years when inspections are required.

- Assumes that efficiencies will be obtained by performing all inspections and maintenance under joint plans.

Altemative II: Poet-Closure Monitoring for Closure in Place whh Administrative Controls wtth Construction of Covers

- Assumes that all CASs will require dive-by inspections annually during post-closure years 1 through 5 and every 5 years thereafter until year 20 (i.e. inspections during post-ctosure years $1,2,3,4,5,10,15$, and 20 ).

- Assumes that post-closure maintenance activities will consist of replacing and repairing signs, posts, and fencing, with additional repair to covers, all of which will take 2 days per CAS. Assumes that an average of 50 cubic yards of additional soll will need to be transported to each of the sites.

- Assumes that maintenance will be required at all sites during years 2 and 5, but that no maintenance will be required in other years.

- Assumes that the post-closure report will consist of a letter report that is required only during those years when inspections are required.

- Assumes that efficiencies will be obtained by performing all inspections and maintenance under joint plans.

\section{ASSUMPTIONS:}

- Work to be pertormed by BN duning a "normal" workday (no provision for overtime has been provided). Shitts are based on 10-hour days / 4-days per week. - Post closure monitoring will be needed as indicated in the assumptions.

- The amount of time and resources necessary to complete post-closure monitoring of each site may vary, depending on individual site conditions post-closure. - Access to the site will be available and unrestricted throughout field activities.

\section{ESCALATION:}

No escalation factors have been applied. All costs are in FY03 dollars.

\section{CONTINGENCY:}

Contingency costs are not included in this estimate. 


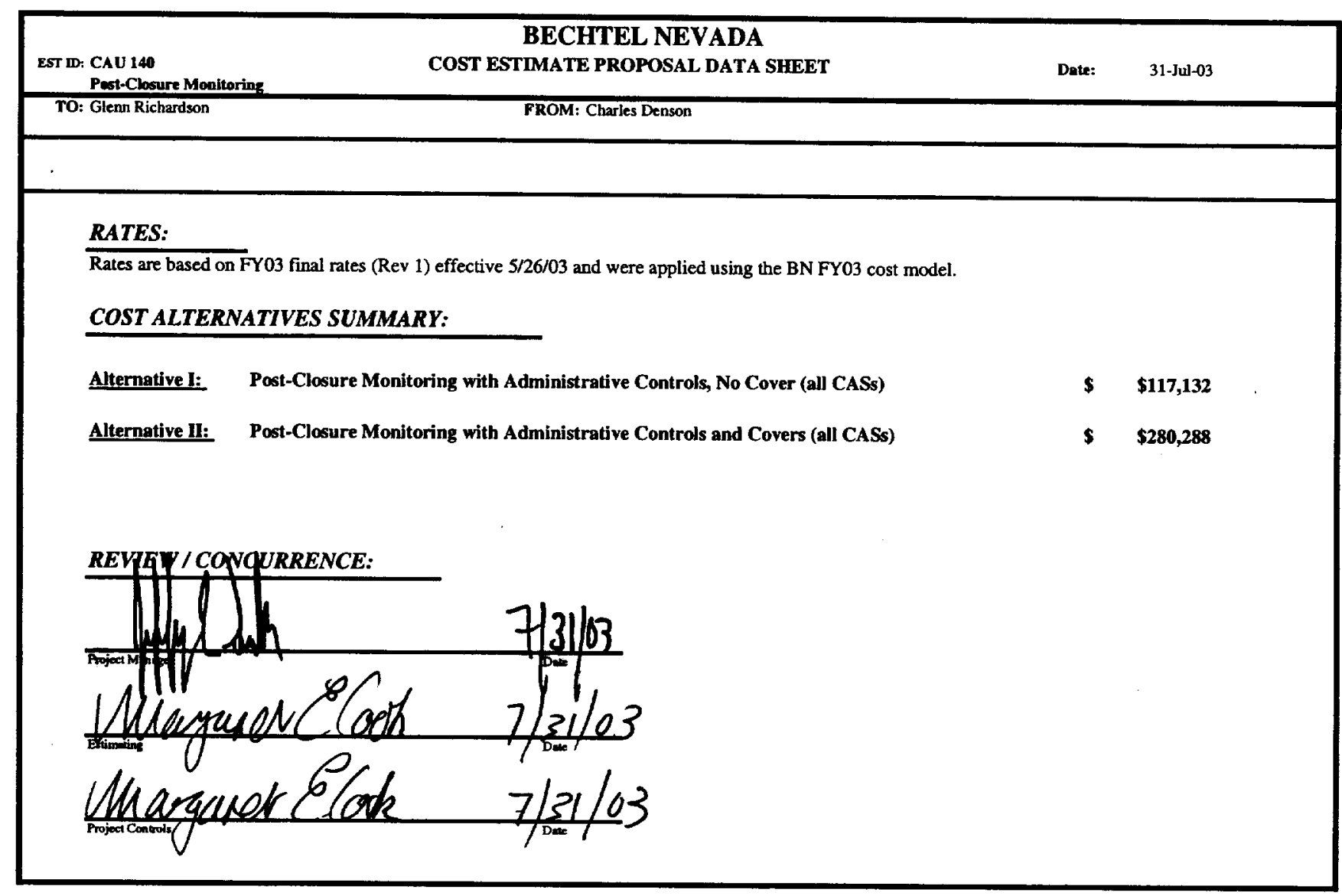


SUBJECT: CADD Alternative Cost Estimates for CAU-140: Areas 5, 22, \& 23 Waste Dumps, Burn Pits, and Storage Area, NTS

ESTIMATOR: Charles Denson $\quad$ REF \#:

TYPE OF ESTIMATE:

$\mathbf{x}$ ORDER OF MAGNTTUDE PRELMMRARY / PLANNING / STUDY CONCEPTUAL / BUDGET TITLE I
TYPE OF WORK:

TITLE I

WORK ORDER COMPARATIVE OTHER
NON-MANUAL ONLY

MANUAL ONLY

$\overline{\mathbf{X}}$ MANUAL \& NON-MANUAL OTHER

PROJECT WORK SCOPE IS EXPECTED TO BE PERFORMED BY

DOE PRIME (LUMP SUM) BN CONSTRUCTION $\mathbf{X}$ BN MAINTENANCE
SUBCONIRACT

GPP

\section{STATEMENT OF WORK}

This estimate has been prepared to provide remedial altemative costs for the closure of Corrective Action Site (CAS) 23-17-01, which is included within Corrective Action Unit (CAU) 140. CAU 140 CAS 23-17-01 is an environmental restoration site listed in the Federal Facility Agreement and Consent Order (FFACO). CAS 23-17-01 was described within the FFACO as the Hazardous Waste Storage Area in Area 23. Three alternatives have been evaluated for closure of the CAS: I. No Further Action; II. Clean Closure; and III Closure in Place with Administrative Controls. This estimate will be used to identify the most cost effective alternative for closure of the site while remaining protective of human health and the environment. The total estimated costs are intended for comparative analysis of remedial fieldwork cost only. Cost for project management, plan preparation, project support, and/or other activities are not included herein.

\section{SCOPE:}

Provide site closure using one of the following alternatives:

1) NO FURTHER ACTION

II) CLEAN CLOSURE BY EXCAVATION AND REMOVAL

III) CLOSURE IN PLACE WITH ADMINISTRATIVE CONTROLS

\section{BASIS:}

The characterization contractor recently completed field measurements and sample analyses for the hazardous waste storage area that required remedial action for 236 cubic yards of TPH impacted soil. Site closure estimates for each alternative were priced using standard construction references such as RS Means, Richardson's, and the BN estimating database. There is no estimate required for evaluation of the No Further Action alternative since no cost is incurred.

\section{ALTERNATIVE SPECIFIC BASIS OF ESTIMATE/ASSUMPTIONS}

Alternative II: Clean Closure

- Remove clean overburden soil (131 cu. yds.).

- Remove TPH impacted soil from hazardous waste storage area (236 cu. yds.).

- Perform a Field Screening analysis for TPH-impacted soil removal.

- Collect five verification samples for TPH (DRO).

- Backfill open depression created during soil removal (367 cu. yds.) with clean overburden and clean fill material.

Alternative ill: Closure in Place with Administrative Controls

- Install four drive over monuments with permanent brass tags.

- Grade landfill area to control Runon/Runoff.

- Install and implement administrative controls.

- Develop and document appropriate use restrictions. 


\section{ASSUMPTIONS:}

- No corrective actions are required for the surrounding areas outside this CAS boundany

- No surface impediments.

- Soil benching that may be required during excavation is not included in the volume or estimate.

- All COCs at the site have been identitied during the site investigation and analytical data accurately represents site conditions and waste characteristics.

- The only COC discovered during the site investigation was TPH.

- Equipment will be available and remain operational to support the planned/scheduled completion of each CAOD alternative.

- Waste volumes are based on field measurements collected during the corrective action investigation and may be affected by weather events prior to completing the corrective actions.

- Work to be performed by BN during a "normal" workday (no provision for overtime has been provided). Shifts are based on 10-hour days / 4-days per week.

- This estimate does not include efficiencies which may be realized if work for similar activities at similar sites can be completed concurrently.

- This estimate does not include costs for preparation of required project plans, permits, reports, mobilization and demobilization, site preparations, or project management.

- Dimensions, volumes, measurements, and analytical data provided by the A\&E contractor accurately represent site conditions and waste characteristics.

\section{ESCALATION:}

No escalation factors have been applied. All costs are in FY03 dollars.

\section{CONTINGENCY:}

Contingency costs are not included in this estimate.

\section{RATES:}

Rates are based on FY03 Final rates (Rev 1) effective 5/26/03 and were applied using the BN FY03 cost model.

\section{COST ALTERNATIVES SUMMARY:}

Alternative I: No Further Action

a. Remove Overburden Soil (13l cu. yds.)

b. Remove TPH Impacted Soil (236 cu. yds.)

c. Perform Field Screening Analysis of TPH Impacted Soil

d. Collect Verification Samples

e. Backfill Depression Areas with Clean Fill Material

f. Waste Management

Alternative III: Closure in Place with Administrative Controls

a. Install Four Drive Over Landfill Monuments

b. Grade Landfill Cover to Runon/Runoff

c. Install and Implement Administrative Controls

d. Use Restrictions, Survey, and Post Closure Care

\section{REYLFW / CQNCURRENCE:}

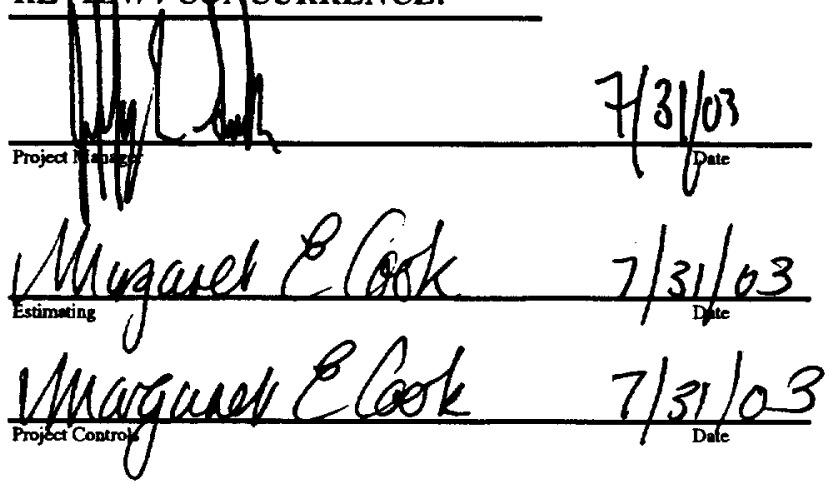




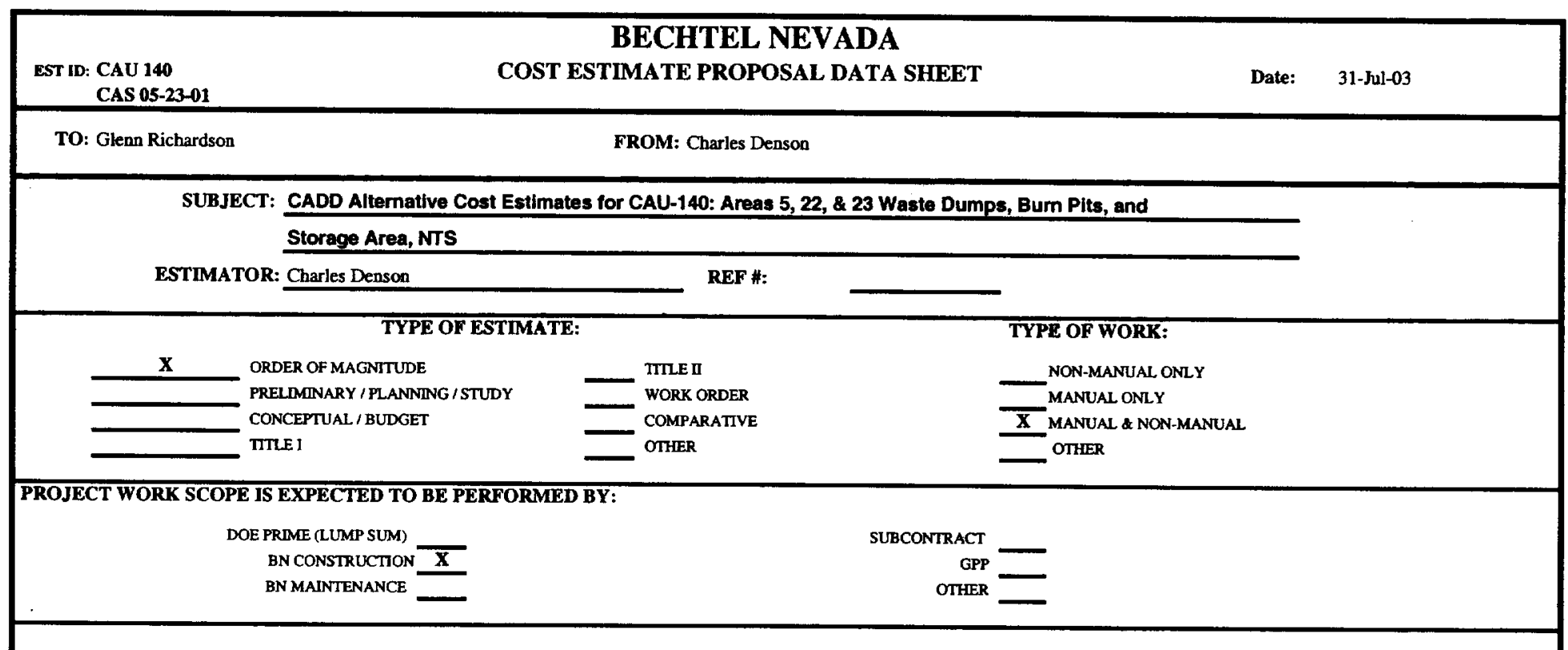

\section{STATEMENT OF WORK}

This estimate has been prepared to provide remedial alternative costs for the closure of Corrective Action Site (CAS) 25-99-16, which is included within Corrective Action Unit (CAU) 140. CAU 140 CAS 05-23-01 is an environmental restoration site listed in the Federal Facility Agreement and Consent Order (FFACO). CAS 05-23-01 was described within the FFACO as the Gravel Gertie structure, located on the west side of the 05-01 Road. Two altematives have been evaluated for closure of the CAS: Alternative I. No Further Action and Alternative III. Closure in Place with Administrative Controls. This estimate will be used to identify the most cost effective alternative for closure of the site while remaining protective of human health and the environment. The total estimated costs are intended for comparative analysis of remedial fieldwork cost only. Cost for project management, plan preparation, project support, and/or other activities are not included herein.

\section{SCOPE:}

Provide site closure using one of the following alternatives:

I) NO FURTHER ACTION

II) CLEAN CLOSURE BY EXCAVATION AND REMOVAL

III) CLOSURE IN PLACE WITH ADMINISTRATIVE CONTROLS

\section{BASIS:}

The characterization contractor recently completed field and radiological survey measurements for select areas of the Gravel Gertie structure that indicated Uranium 235 was detected above the PAL in the soil on the roof. As a result of the sampling effort and historical documentation, the Gravel Gertie structure is considered to be contaminated. A site closure estimate for the closure in place alternative was priced using standard construction references such as RS Means, Richardson's, and the BN estimating database. An estimate for clean closure was not developed because the characterization contractor did not characterize the specific site location. There is no estimate required for evaluation of the No Further Action alternative since no cost is incurred.

\section{ALTERNATIVE SPECIFIC BASIS OF ESTIMATE/ASSUMPTIONS}

\section{Alternative I: No Further Action}

Alternative II: Clean Closure

- None.

Alternative III: Closure in Place with Administrative Controls

- Install a 1,200 linear ft., 3-strand, yellow wire fence.

- Install and impiement administrative controls.

- Develop and document appropriate use restrictions. 


\section{ASSUMPTIONS:}

- No corrective actions are required for the areas within the Gravel Gertie structure.

- The Gravel Gertie structure is contaminated internally and externally.

- The Clean Closure alternative was not applicable due to ALARA and the questionnable integrity of the Gravel Gertie structure.

- All COCs at the site have been identified during the site investigation and analytical data accurately represents site conditions and waste characteristics.

- Equipment will be available and remain operational to support the planned/scheduled completion of each CADD alternative.

- Waste volumes are based on field measurements collected during the corrective action investigation and may be affected by weather events prior to

completing the corrective actions.

- Work to be performed by BN during a "normal" workday (no provision for overtime has been provided). Shifts are based on 10-hour days / 4-days per week.

- This estimate does not include efficiencies which may be realized if work for similar activities at similar sites can be completed concurrently

- This estimate does not include costs for preparation of required project plans, permits, reports, mobilization and demobilization, site preparations, or project management

- Dimensions, volumes, measurements, and analytical data provided by the A\&E contractor accurately represent site conditions and waste characteristics.

\section{ESCALATION:}

No escalation factors have been applied. All costs are in FY03 dollars.

\section{CONTINGENCY:}

Contingency costs are not included in this estimate.

\section{RATES:}

Rates are based on FY03 Final rates (Rev 1) effective 5/26/03 and were applied using the BN FY03 cost model.

\section{COST ALTERNATIVES SUMMARY:}

\section{Alternative 1: No Further Action}

\section{Alternative II: Clean Closure}

Alternative III: Closure in Place with Administrative Controls

a. Install 1,200 Linear $\mathrm{ft}$, 3-Strand, Wire Fence

b. Install and Implement Administrative Controls

c. Use Restrictions, Survey, and Post Closure Care

\section{REVIEW, CONCURRENCE:}

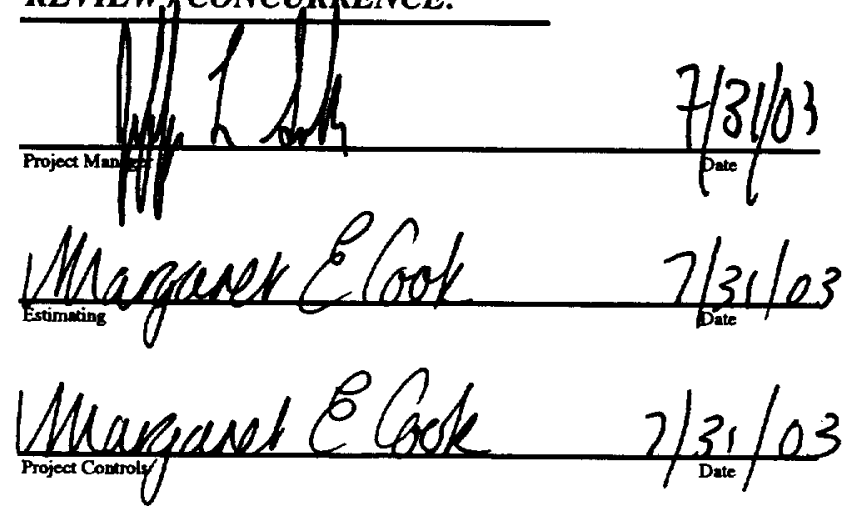




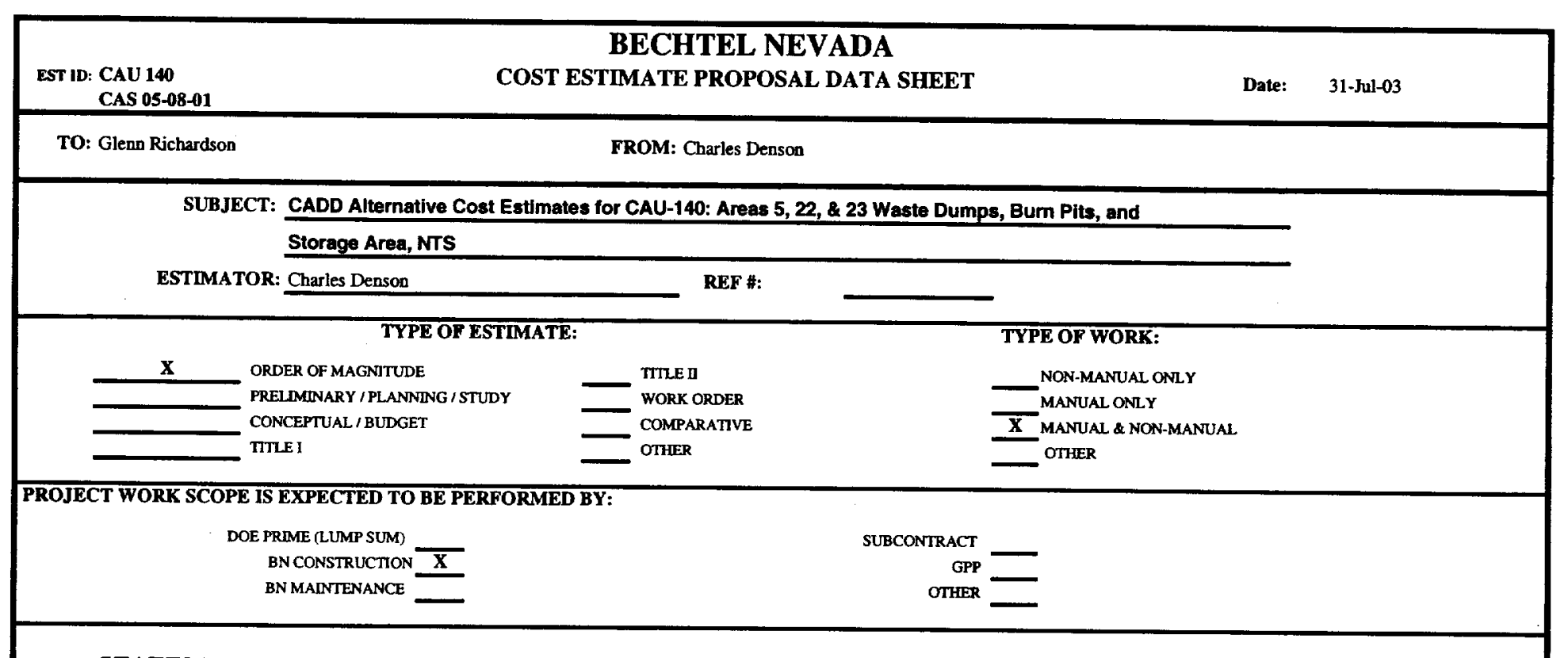

\section{STATEMENT OF WORK}

This estimate has been prepared to provide remedial alternative costs for the closure of Corrective Action Site (CAS) 05-08-01, which is included within Corrective Action Unit (CAU) 140. CAU 140 CAS 05-08-01 is an environmental restoration site listed in the Federal Facility Agreement and Consent Order (FFACO). CAS 05-08-01 was described within the FFACO as the Detonation Pits in Area 5 . Three alternatives have been evaluated for closure of the CAS: I. No Further Action; II. Clean Closure; and III Closure in Place with Administrative Controls. This estimate will be used to identify the most cost effective alternative tor closure of the site while remaining protective of human health and the environment. The total estimated costs are intended for comparative analysis of remedial fieldwork cost only. Cost for project management, plan preparation, project support, and/or other activities are not included herein.

\section{SCOPE:}

Provide site closure using one of the following alternatives:

1) NO FURTHER ACTION

II) CLEAN CLOSURE BY EXCAVATION AND REMOVAL

III) CLOSURE IN PLACE WITH ADMINISTRATIVE CONTROLS

\section{BASIS:}

The characterization contractor recently completed field measurements and sample analyses for the detonation pits and adjacent areas. Constituents of concern that were delected in the soil above PALs and requiring remedial action include: Lead, Thorium-234 and U-235. Some of the debris materials include a metal edging around the detonation pits, detonation wire, and shrapnel debris. Site closure estimates for each alternative were priced using standard construction references such as RS Means, Richardson's, and the BN estimating database. There is no estimate required for evaluation of the No Further Action alternative since no cost is incurred.

\section{ALTERNATIVE SPECIFIC BASIS OF ESTIMATE/ASSUMPTIONS}

Alternative II: Clean Closure

- Remove metal edging around the detonation pits.

- Remove the Lead,Th-234, and U-235 impacted soil around a sample location near the detonation pits.

- Perform a Field Screening analysis for Lead-impacted soil removal.

- Perform a radiological survey to confirm the Rad-impaced soil has been removed to be below the PAL.

- Collect a verification sample for total RCRA Metals and Gamma Spec.

- Backfill depression created during soil removal (14.8 cu. yds.) with clean soil material.

Alternative Itl: Closure in Place with Administrative Controls

- Install a 40 linear ft., 3-strand, wire fence.

- Install and implement administrative controls.

- Develop and document appropriate use restrictions. 
BECHTEL NEVADA

COST ESTIMATE PROPOSAL DATA SHEET

Date:

31-Jud-03

TO: Glenn Richardson

FROM: Charles Denson

\section{ASSUMPTIONS:}

- No corrective actions are required for the surrounding areas outside this CAS boundary.

- The surface layer of soil (from 0-1 ft) at sample location A05 will be disposed of as a mixed waste. This is primarily due to the detection of lead, U-235, and Th-234 in the same sample location above the PALs.

- All COCs al the site have been identified during the site investigation and analytical data accurately represents site conditions and waste characteristics.

- The only COC discovered during the site investigation were Lead, Th-234, and U-235.

- Equipment will be available and remain operational to support the planned/scheduled completion of each CADD alternative.

- Waste volumes are based on field measurements collected during the corrective action investigation and may be affected by weather events prior to completing the corrective actions.

- Work to be performed by BN during a "normal" workday (no provision for overtime has been provided). Shifts are based on 10-hour days / 4-days per week.

- This estimate does not include efficiencies which may be realized if work for similar activities at similar sites can be completed concurrently.

- This estimate does not include costs for preparation of required project plans, permits, reports, mobilization and demobilization, site preparations, or project management.

- Dimensions, volumes, measurements, and analytical data provided by the A\&E contractor accurately represent site conditions and waste characteristics

\section{ESCALATION:}

No escalation factors have been applied. All costs are in FY03 dollars.

\section{CONTINGENCY:}

Contingency costs are not included in this estimate.

\section{RATES:}

Rates are based on FY03 Final rates (Rev 1) effective 5/26/03 and were applied using the BN FY03 cost model.

\section{COST ALTERNATIVES SUMMARY:}

Alternative I: No Further Action

a. Remove Metal Edging, Detonation Wire, and Shrapnel Debris

b. Remove $14.8 \mathrm{cu}$. yds. of Lead, Th-235, and U-235 Impacted Soil

c. Perform Field Screening Analysis of Lead Impacted Soi]

d. Perform Radiological Survey

e. Collect Verification Samples

f. Backfill Depression Areas with Clean Fill Material

g. Waste Management

Alternative III: Closure in Place with Administrative Controls

a. Install 40 Linear ft., 3-Strand, Wire Fence

b. Install and Implement Administrative Controls

c. Use Restrictions, Survey, and Post Closure Care

REVIEW/CONCURRENCE:

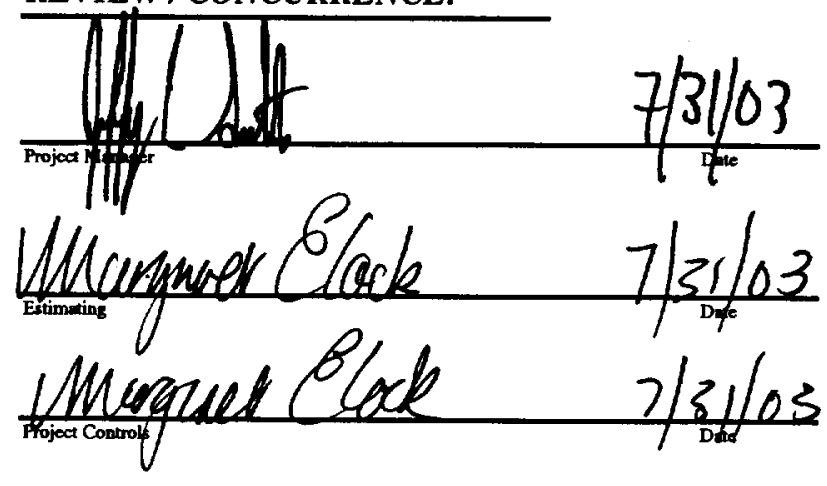


Appendix D

Sample Location Coordinates for CAU 140 


\section{D.1.0 Sample Location Coordinates}

Sample location coordinates were collected during field activities, using a Trimble GPS (Model TSCI). These coordinates identify the field sampling locations (e.g., latitude, longitude, elevation) and points of interest at each CAS in CAU 140.

\section{D.1.1 Detonation Pits (CAS 05-08-01)}

Sample locations and pertinent points of interest at CAS 05-08-01 are shown on Figure A.3-1. The corresponding coordinates for CAS 05-08-01 sample locations are listed in Table D.1-1.

Table D.1-1

Sample Location Coordinates for CAS 05-08-01, Sample Locations and Points of Interest

\begin{tabular}{||l|c|c|c|c|c|c|c||}
\hline Latitude & Longitude & Northing $^{\mathrm{a}}$ & Easting $^{\mathrm{a}}$ & $\begin{array}{c}\text { HAE } \\
\text { (meters) }\end{array}$ & Comment & $\begin{array}{c}\text { Horizontal } \\
\text { Precision } \\
\text { (meters) }\end{array}$ & $\begin{array}{c}\text { Vertical } \\
\text { Precision } \\
\text { (meters) }\end{array}$ \\
\hline \hline 36.84738 & -115.988 & 4078218 & 590261.1 & 992.73 & $\mathrm{~A} 01$ & 1.025 & 1.682 \\
\hline 36.84745 & -115.988 & 4078225 & 590251.4 & 992.77 & $\mathrm{~A} 02$ & 1.023 & 1.678 \\
\hline 36.84754 & -115.988 & 4078235 & 590253.8 & 993 & $\mathrm{~A} 03$ & 1.023 & 1.678 \\
\hline 36.84809 & -115.988 & 4078296 & 590244.5 & 994.65 & Gravel pile & 1.023 & 1.678 \\
\hline 36.84814 & -115.988 & 4078301 & 590234.2 & 994.72 & Pad & 1.023 & 1.678 \\
\hline 36.84868 & -115.988 & 4078361 & 590201.1 & 994.94 & $\mathrm{~A} 04$ & 1.023 & 1.678 \\
\hline 36.84871 & -115.988 & 4078365 & 590211.5 & 994.82 & $\mathrm{~A} 05$ & 1.023 & 1.678 \\
\hline 36.84872 & -115.988 & 4078365 & 590210.2 & 994.61 & $\mathrm{~A} 06$ & 1.023 & 1.678 \\
\hline 36.84873 & -115.988 & 4078366 & 590210.9 & 995.68 & $\mathrm{~A} 07$ & 1.418 & 1.965 \\
\hline 36.84871 & -115.988 & 4078364 & 590211.7 & 994.42 & $\mathrm{~A} 08$ & 1.416 & 1.974 \\
\hline
\end{tabular}

aUniversal Transverse Mercator (UTM) TM Zone 11, NAD 27

HAE = Height above ellipsoid

\section{D.1.2 Debris PIts (CAS 05-08-02)}

Sample locations and pertinent points (locations) of interest at CAS 05-08-02 are shown on Figure A.4-1. The corresponding coordinates for CAS 05-08-02 sample locations are listed in Table D.1-2. 
Table D.1-2

Sample Location Coordinates for CAS 05-08-02, Sample Locations and Points of Interest

\begin{tabular}{||c|c|c|c|c|c|c|c|}
\hline Latitude & Longitude & Northing & Easting & $\begin{array}{c}\text { HAE } \\
\text { (meters) }\end{array}$ & Comment & $\begin{array}{c}\text { Horizontal } \\
\text { Precision } \\
\text { (meters) }\end{array}$ & $\begin{array}{c}\text { Vertical } \\
\text { Precision } \\
\text { (meters) }\end{array}$ \\
\hline \hline 36.76101 & -115.965 & 4068659 & 592423.4 & 965.28 & B01 & 0.903 & 1.289 \\
\hline 36.76085 & -115.964 & 4068641 & 592444 & 966.8 & B02 & 0.902 & 1.289 \\
\hline 36.76095 & -115.964 & 4068652 & 592444.4 & 967.51 & B03 & 0.902 & 1.289 \\
\hline 36.76103 & -115.964 & 4068661 & 592431.5 & 968.22 & B04 & 0.902 & 1.289 \\
\hline 36.76101 & -115.964 & 4068658 & 592428.8 & 968.49 & B05 & 0.946 & 1.336 \\
\hline 36.76117 & -115.964 & 4068676 & 592431.2 & 968.81 & B06 & 1.026 & 1.416 \\
\hline 36.76117 & -115.965 & 4068676 & 592398.6 & 968.46 & B07 & 1.036 & 1.442 \\
\hline 36.76122 & -115.965 & 4068682 & 592399.2 & 969.56 & B08 & 1.036 & 1.442 \\
\hline
\end{tabular}

aUTM Zone 11, NAD 27

HAE = Height above ellipsoid

\section{D.1.3 Hazardous Waste Accumulation Site (Buried) (CAS 05-17-01)}

Sample locations and pertinent points (locations) of interest at CAS 05-17-01 are shown on Figure A.5-1. The corresponding coordinates for CAS 05-17-01 sample locations are listed in Table D.1-3.

\section{D.1.4 Waste Disposal Site (CAS 05-19-01)}

Sample locations and pertinent points (locations) of interest at CAS 05-19-01 are shown on Figure A.6-1. The corresponding coordinates for CAS 05-19-01 sample locations are listed in Table D.1-4.

\section{D.1.5 Gravel Gertie (CAS 05-23-01)}

Sample locations and pertinent points (locations) of interest at CAS 05-23-01 are shown on Figure A.6-1. The corresponding coordinates for CAS 05-23-01 sample locations are listed in Table D.1-5. 
Table D.1-3

Sample Location Coordinates for CAS 05-17-01, Sample Locations and Points of Interest

\begin{tabular}{||l|c|c|c|c|c|c|c||}
\hline Latitude & Longitude & Northing & Easting & $\begin{array}{c}\text { HAE } \\
\text { (meters) }\end{array}$ & Location & $\begin{array}{c}\text { Horizontal } \\
\text { Precision } \\
\text { (meters) }\end{array}$ & $\begin{array}{c}\text { Vertical } \\
\text { Precision } \\
\text { (meters) }\end{array}$ \\
\hline \hline 36.82828 & -115.985 & 4076102 & 590515.2 & 972.12 & $\mathrm{C} 01$ & 0.993 & 1.534 \\
\hline 36.82847 & -115.985 & 4076122 & 590525.8 & 972.99 & $\mathrm{C} 02$ & 0.993 & 1.534 \\
\hline 36.82856 & -115.985 & 4076132 & 590503.7 & 973.81 & $\mathrm{C} 03$ & 0.993 & 1.534 \\
\hline 36.82834 & -115.985 & 4076108 & 590499.3 & 974.65 & $\mathrm{C} 04$ & 1.26 & 1.892 \\
\hline 36.82844 & -115.985 & 4076118 & 590507.3 & 974.63 & $\mathrm{C} 05$ & 1.26 & 1.892 \\
\hline
\end{tabular}

aUTM Zone 11, NAD 27

HAE = Height above ellipsoid

Table D.1-4

Sample Location Coordinates for CAS 05-19-01, Sample Locations and Points of Interest

\begin{tabular}{||c|c|c|c|c|c|c|c||}
\hline Latitude & Longitude & Northing $^{\mathrm{a}}$ & Easting $^{\mathrm{a}}$ & $\begin{array}{c}\text { HAE } \\
\text { (meters) }\end{array}$ & Location & $\begin{array}{c}\text { Horizontal } \\
\text { Precision } \\
\text { (meters) }\end{array}$ & $\begin{array}{c}\text { Vertical } \\
\text { Precision } \\
\text { (meters) }\end{array}$ \\
\hline \hline 36.81884 & -115.939 & 4075098 & 594591.8 & 934.38 & $\mathrm{D} 01$ & 1.387 & 2.306 \\
\hline 36.8188 & -115.939 & 4075094 & 594606.8 & 934.31 & $\mathrm{D} 02$ & 1.387 & 2.306 \\
\hline 36.81894 & -115.939 & 4075110 & 594671.6 & 934.1 & $\mathrm{D} 03$ & 1.365 & 2.168 \\
\hline 36.81881 & -115.939 & 4075095 & 594668.5 & 934.1 & $\mathrm{D} 04$ & 1.376 & 2.239 \\
\hline 36.81894 & -115.939 & 4075110 & 594663.6 & 934.05 & $\mathrm{D} 05$ & 1.376 & 2.239 \\
\hline 36.81886 & -115.939 & 4075101 & 594669 & 934.09 & $\mathrm{D} 06$ & 1.376 & 2.239 \\
\hline 36.81914 & -115.938 & 4075133 & 594711.7 & 933.85 & $\mathrm{D} 07$ & 1.365 & 2.168 \\
\hline 36.82007 & -115.939 & 4075235 & 594662.1 & 931.04 & $\mathrm{Bkg} 01$ & 7.8 & 5.7 \\
\hline
\end{tabular}

aUTM Zone 11, NAD 27

HAE = Height above ellipsoid

\section{D.1.6 Burn Pit (CAS 05-35-01)}

Sample locations and pertinent points (locations) of interest at CAS 05-35-01 are shown on

Figure A.8-1. The corresponding coordinates for CAS 05-35-01 sample locations are listed in Table D.1-6. 
Table D.1-5

Sample Location Coordinates for CAS 05-23-01, Sample Locations and Points of Interest

\begin{tabular}{||c|c|c|c|c|c|c|c||}
\hline Latitude & Longitude & Northing $^{\mathrm{a}}$ & Easting $^{\mathrm{a}}$ & $\begin{array}{c}\text { HAE } \\
\text { (meters) }\end{array}$ & Location & $\begin{array}{c}\text { Horizontal } \\
\text { Precision } \\
\text { (meters) }\end{array}$ & $\begin{array}{c}\text { Vertical } \\
\text { Precision } \\
\text { (meters) }\end{array}$ \\
\hline \hline 36.7633 & -115.97 & 4068907 & 591913 & 956.17 & $\mathrm{E} 01$ & 1.134 & 1.625 \\
\hline 36.76348 & -115.97 & 4068927 & 591942.1 & 956.33 & $\mathrm{E} 02$ & 1.121 & 1.607 \\
\hline 36.76353 & -115.97 & 4068933 & 591973.6 & 964.91 & $\mathrm{E} 03$ & 1.118 & 1.603 \\
\hline 36.76355 & -115.969 & 4068936 & 591977.5 & 964.93 & $\mathrm{E} 04$ & 1.12 & 1.602 \\
\hline 36.7642 & -115.969 & 4069008 & 592047.8 & 956.42 & $\mathrm{E} 05$ & 1.005 & 1.382 \\
\hline
\end{tabular}

aUTM Zone 11, NAD 27

HAE = Height above ellipsoid

Table D.1-6

Sample Location Coordinates for CAS 05-35-01, Sample Locations and Points of Interest

\begin{tabular}{||c|c|c|c|c|c|c|c||}
\hline Latitude & Longitude & Northing $^{\mathrm{a}}$ & Easting $^{\mathrm{a}}$ & $\begin{array}{c}\text { HAE } \\
\text { (meters) }\end{array}$ & Comment & $\begin{array}{c}\text { Horizontal } \\
\text { Precision } \\
\text { (meters) }\end{array}$ & $\begin{array}{c}\text { Vertical } \\
\text { Precision } \\
\text { (meters) }\end{array}$ \\
\hline \hline 36.85022 & -115.955 & 4078563 & 593166.8 & 959.01 & F01 & 0.962 & 1.543 \\
\hline 36.85007 & -115.955 & 4078547 & 593156.9 & 959.11 & F02 & 0.937 & 1.497 \\
\hline 36.85002 & -115.955 & 4078541 & 593170 & 959.4 & F03 & 0.938 & 1.504 \\
\hline 36.85016 & -115.955 & 4078557 & 593180.3 & 959.78 & F04 & 0.938 & 1.504 \\
\hline 36.85024 & -115.955 & 4078566 & 593160.3 & 960.04 & Pad & 0.938 & 1.504 \\
\hline
\end{tabular}

aUTM Zone 11, NAD 27

$\mathrm{HAE}=$ Height above ellipsoid

\section{D.1.7 Burn Pit (CAS 05-99-04)}

Sample locations and pertinent points (locations) of interest at CAS 05-99-04 are shown on Figure A.9-1. The corresponding coordinates for CAS 05-99-04 sample locations are listed in Table D.1-7. 
Table D.1-7

Sample Location Coordinates for CAS 05-99-04, Sample Locations and Points of Interest

\begin{tabular}{|c|c|c|c|c|c|c|c|}
\hline Latitude & Longitude & Northing & Easting & $\begin{array}{c}\text { HAE } \\
\text { (meters) }\end{array}$ & Location & $\begin{array}{c}\text { Horizontal } \\
\text { Precision } \\
\text { (meters) }\end{array}$ & $\begin{array}{c}\text { Vertical } \\
\text { Precision } \\
\text { (meters) }\end{array}$ \\
\hline \hline 36.80262 & -115.97 & 4073269 & 591922.7 & 944.439 & G01 & 0.3 & 0.660402 \\
\hline 36.80263 & -115.97 & 4073271 & 591911.8 & 949.795 & G02 & 5.6 & 0.550885 \\
\hline 36.803 & -115.97 & 4073311 & 591907.8 & 943.693 & G03 & 5.5 & 0.258873 \\
\hline
\end{tabular}

aUTM Zone 11, NAD 27

HAE = Height above ellipsoid

\section{D.1.8 Radioactive Waste Dump (CAS 22-99-04)}

Sample locations and pertinent points (locations) of interest at CAS 22-99-04 are shown on Figure A.10-1. The corresponding coordinates for CAS 22-99-04 sample locations are listed in Table D.1-8.

Table D.1-8

Sample Location Coordinates for CAS 22-99-01, Sample Locations and Points of Interest

\begin{tabular}{|c|c|c|c|c|c|c|c|}
\hline Latitude & Longitude & Northing & Easting & $\begin{array}{c}\text { HAE } \\
\text { (meters) }\end{array}$ & Location & $\begin{array}{c}\text { Horizontal } \\
\text { Precision } \\
\text { (meters) }\end{array}$ & $\begin{array}{c}\text { Vertical } \\
\text { Precision } \\
\text { (meters) }\end{array}$ \\
\hline \hline 36.62171 & -116.019 & 4053155 & 587684.1 & 994.08 & $\mathrm{H} 01$ & 1.81 & 3.458 \\
\hline
\end{tabular}

aUTM Zone 11, NAD 27

HAE = Height above ellipsoid

\section{D.1.9 Hazardous Waste Storage Area (CAS 23-17-01)}

Sample locations and pertinent points (locations) of interest at CAS 23-17-01 are shown on Figure A.11-2. The corresponding coordinates for CAS 23-17-01 sample locations are listed in Table D.1-9. 
Table D.1-9

Sample Location Coordinates for CAS 23-17-01, Samples Locations and Points of Interest

\begin{tabular}{||c|c|c|c|c|c|c|c||}
\hline Latitude & Longitude & Northing & Easting & $\begin{array}{c}\text { HAE } \\
\text { (meters) }\end{array}$ & Location & $\begin{array}{c}\text { Horizontal } \\
\text { Precision } \\
\text { (meters) }\end{array}$ & $\begin{array}{c}\text { Vertical } \\
\text { Precision } \\
\text { (meters) }\end{array}$ \\
\hline \hline 36.65872 & -116.012 & 4057266 & 588323.9 & 1107.52 & J01 & 1.51 & 2.304 \\
\hline 36.65851 & -116.012 & 4057243 & 588306 & 1105.82 & J02 & 1.25 & 1.974 \\
\hline 36.65837 & -116.012 & 4057227 & 588288.2 & 1104.82 & J03 & 1.25 & 1.974 \\
\hline 36.65825 & -116.012 & 4057214 & 588277.2 & 1103.99 & J04 & 1.25 & 1.974 \\
\hline 36.65831 & -116.012 & 4057220 & 588266.7 & 1104.09 & J05 & 1.25 & 1.974 \\
\hline 36.65845 & -116.012 & 4057236 & 588284 & 1104.94 & $\mathrm{~J} 06$ & 1.25 & 1.974 \\
\hline 36.6586 & -116.012 & 4057254 & 588299 & 1106.29 & $\mathrm{~J} 07$ & 1.255 & 1.982 \\
\hline 36.65872 & -116.012 & 4057267 & 588312.1 & 1107.06 & $\mathrm{~J} 08$ & 1.267 & 1.928 \\
\hline 36.65787 & -116.011 & 4057173 & 588363.2 & 1102.88 & $\mathrm{~J} 09$ & 1.282 & 2.213 \\
\hline 36.65773 & -116.011 & 4057157 & 588351.2 & 1102.33 & $\mathrm{~J} 10$ & 1.282 & 2.213 \\
\hline 36.65781 & -116.012 & 4057165 & 588318.8 & 1102.21 & $\mathrm{~J} 11$ & 1.27 & 2.164 \\
\hline 36.65806 & -116.012 & 4057193 & 588272.1 & 1102.68 & $\mathrm{~J} 12$ & 1.252 & 2.09 \\
\hline 36.65828 & -116.013 & 4057217 & 588237 & 1103.14 & $\mathrm{~J} 13$ & 1.252 & 2.09 \\
\hline 36.65866 & -116.013 & 4057259 & 588238.1 & 1105.09 & $\mathrm{~J} 14$ & 1.252 & 2.09 \\
\hline 36.65853 & -116.012 & 4057245 & 588270.8 & 1105.07 & $\mathrm{~J} 15$ & 1.25 & 1.974 \\
\hline 36.65864 & -116.012 & 4057258 & 588303.1 & 1107 & $\mathrm{~J} 16$ & 1.254 & 1.958 \\
\hline 36.6583 & -116.012 & 4057220 & 588295.2 & 1104.66 & $\mathrm{~J} 17$ & 1.324 & 2.332 \\
\hline 36.65806 & -116.012 & 4057194 & 588338.1 & 1103.69 & $\mathrm{~J} 18$ & 1.287 & 2.226 \\
\hline 36.65875 & -116.011 & 4057271 & 588381 & 1108.29 & $\mathrm{~J} 19$ & 1.307 & 1.748 \\
\hline 36.65897 & -116.011 & 4057295 & 588353.5 & 1109.12 & $\mathrm{~J} 20$ & 1.327 & 1.775 \\
\hline 36.65901 & -116.011 & 4057299 & 588354 & 1108.29 & $\mathrm{~J} 21$ & 1.31 & 1.574 \\
\hline 36.65894 & -116.011 & 4057291 & 588355.8 & 1107.93 & $\mathrm{~J} 22$ & 1.31 & 1.574 \\
\hline 36.65896 & -116.011 & 4057294 & 588349.3 & 1107.92 & $\mathrm{~J} 23$ & 1.31 & 1.574 \\
\hline
\end{tabular}

aUTM Zone 11, NAD 27

HAE = Height above ellipsoid 


\section{Appendix E}

Evaluation of Risk 


\section{E.1.0 Evaluation of Risk}

A detailed assessment of risk for no action and evaluated alternatives was not performed because COCs exceeding PALs are not present or will not be left in place without appropriate controls. 
Appendix F

Project Organization for CAU 140 


\section{F.1.0 Project Organization}

The NNSA/NSO Project Manager is Janet Appenzeller-Wing and her telephone number is (702) 295-0461.

The identification of the project Health and Safety Officer and the Quality Assurance Officers can be found in the appropriate plan. However, personnel are subject to change and it is suggested that the appropriate DOE Project Manager be contacted for further information. The Task Manager will be identified in the FFACO Biweekly Activity Report prior to the start of field activities. 
Appendix G

NDEP Comments

(1 page) 


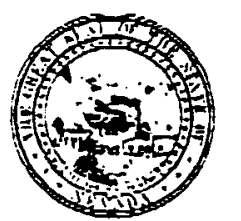

\section{DEPARTMENT OF COASERVATION AND NATURAL RESOURCES \\ DIVISION OF ENVIRONMENTAL PROTECTION \\ (Las Vegas Office) \\ 1771 E. Flamingo Road, Suite $121 \cdot$ A \\ Las Vegas, Nevada 89119-0837 \\ September 10, 2003}

Ms. Runore C. Wycoff

Director, Environmental Restoration Division

Nevada Nuclear Security Administration

Nevada Site Office

P. O. Box 98518

Las Vegas, NV 89193-8518

RE: Review of Draft Corrective Action Decision Document

Corrective Action Unit 140, Waste Dumps, Burn Pits, and Storage Area

Federal Facility Agreement and Consent Order

The Nevada Division of Environmental Protection, Bureau of Federal Facilities (NDEP) staff Waste Dumps, Bum Pits, and Storage Area.

NDEP's review of this document did not identify any deficiencies.

Address any questions regarding this matter to ejther Clem Goewert at (702) 486-2865, or Karen
Beckley at (775) 687-9390.

Sincerely,

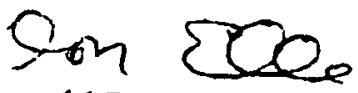

Donald R. Elle, $\mathrm{PhD}$

Supervisor, Las Vegas Office

Bureau of Federal Facilities.

$\mathrm{PJL} / \mathrm{KKB} / \mathrm{KFW} / \mathrm{DRE} / \mathrm{CJG} / \mathrm{cb}$

ce:

Ken Hoar, Director, ES\&HD, NNSANSO

Eric Shanholz, Chief, DTRA

Frank Di Sanza, WMD, NNSA NSO

Patti Hall, EM, NNSA NSO

Janet Appenzeller-Wing, ERD, NASA NSO

Tiffany Lantow, DTRAIDTON

Wayne Griffin, BNDTRRA

Kevin Cabble, ERD, NNSANSO 


\section{Distribution}

*Provide copy in initial distribution of Revision 0 and subsequent revisions, if applicable. Copies of the NDEP-approved document will be distributed to others.

\section{$\underline{\text { Copies }}$}

Paul J. Liebendorfer

1 (Controlled)*

State of Nevada

Bureau of Federal Facilities

Division of Environmental Protection

333 W. Nye Lane, Room 138

Carson City, NV 89706-0851

Donald R. Elle, Las Vegas Office

1 (Controlled)*

State of Nevada

Bureau of Federal Facilities

Division of Environmental Protection

1771 E. Flamingo Road, Suite 121-A

Las Vegas, NV 89119

Shirley Doty

Environmental Restoration Division

1 (Controlled)*

U.S. Department of Energy

National Nuclear Security Administration

Nevada Site Office

P.O. Box 98518, M/S 505

Las Vegas, NV 89193-8518

Janet Appenzeller-Wing

Environmental Restoration Division

1 (Uncontrolled)*

U.S. Department of Energy

National Nuclear Security Administration

Nevada Site Office

P.O. Box 98518, M/S 505

Las Vegas, NV 89193-8518 


\section{$\underline{\text { Copies }}$}

U.S. Department of Energy

1 (Uncontrolled)

National Nuclear Security Administration

Nevada Site Office

Technical Library

P.O. Box 98518, M/S 505

Las Vegas, NV 89193-8518

Southern Nevada Public Reading Facility

1 (Controlled)

c/o Nuclear Testing Archive

1 (Uncontrolled)

P.O. Box 98521, M/S 400

Las Vegas, NV 89193-8521

U.S. Department of Energy

1 (Uncontrolled, electronic copy)

Office of Scientific and Technical Information

P.O. Box 62

Oak Ridge, TN 37831-0062

Kevin Cabble

Environmental Restoration Division

1 (Uncontrolled)*

U.S. Department of Energy

National Nuclear Security Administration

Nevada Site Office

P.O. Box 98518, M/S 505

Las Vegas, NV 89193-8518

Jeffrey L. Smith

1 (Uncontrolled)*

Bechtel Nevada

P.O. Box 98521, M/S NTS306

Las Vegas, NV 89193-8521

Glenn Richardson

1 (Uncontrolled)*

Bechtel Nevada

P.O. Box 98521, M/S NTS306

Las Vegas, NV 89193-8521

Robert L. McCall

1 (Uncontrolled)*

Stoller-Navarro

7710 W. Cheyenne, Building 3

Las Vegas, NV 89129 
Al Wickline

Stoller-Navarro

7710 W. Cheyenne, Building 3

Las Vegas, NV 89129

Stoller-Navarro

Central Files

7710 W. Cheyenne, Building 3

Las Vegas, NV 89129

Phillip Clair, CAB Chairman

6252 Santander Avenue

Las Vegas, NV 89103

Earl Dixon

Community Advisory Board

UNLV, Harry Reid Center for Environmental Studies

4505 S. Maryland Pkwy

Las Vegas, NV 89154

David Swanson

Assistant Project Administrator

Nye County

Department of Natural Resources \& Federal Facilities

1210 E. Basin Road, Suite \#6

Pahrump, NV 89060

Brian Hoenes

Stoller-Navarro

7710 W. Cheyenne, Building 3

Las Vegas, NV 89129

FFFACO Support Office

Stoller-Navarro

7710 W. Cheyenne, Building 3

Las Vegas, NV 89129

Manager, Northern Nevada FFACO

Public Reading Facility

c/o Nevada State Library \& Archives

Carson City, NV 89701-4285
1 (Uncontrolled)*

1 (Uncontrolled)*

1 (Uncontrolled)

1 (Uncontrolled)

1 (Uncontrolled)*

1 (Uncontrolled, electronic copy)

1 (Controlled)

1 (Uncontrolled) 